Florida International University FIU Digital Commons

$7-15-2010$

\title{
Navigating Racial Boundaries: The One-Drop Rule and Mixed-Race Jamaicans in South Florida
}

Sharon E. Placide

Florida International University, placidester@gmail.com

DOI: $10.25148 /$ etd.FI10081209

Follow this and additional works at: https://digitalcommons.fiu.edu/etd

\section{Recommended Citation}

Placide, Sharon E., "Navigating Racial Boundaries: The One-Drop Rule and Mixed-Race Jamaicans in South Florida" (2010). FIU Electronic Theses and Dissertations. 259.

https://digitalcommons.fiu.edu/etd/259 


\title{
FLORIDA INTERNATIONAL UNIVERSITY
}

Miami, Florida

\section{NAVIGATING RACIAL BOUNDARIES: THE ONE-DROP RULE AND MIXED-RACE JAMAICANS IN SOUTH FLORIDA}

\author{
A dissertation submitted in partial fulfillment of the \\ requirements for the degree of \\ DOCTOR OF PHILOSOPHY \\ in
}

COMPARATIVE SOCIOLOGY

by

Sharon E. Placide

2010 


\section{To: Dean Kenneth Furton}

College of Arts and Sciences

This dissertation, written by Sharon E. Placide, and entitled Navigating Racial Boundaries: The One-Drop Rule and Mixed-Race Jamaicans in South Florida, having been approved in respect to style and intellectual content, is referred to you for judgment.

We have read this dissertation and recommend that it be approved.

Jean Muteba Rahier

Dionne Stephens

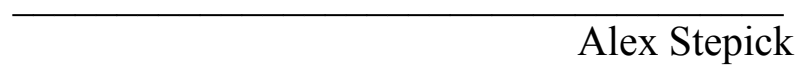

Sarah J. Mahler, Major Professor

Date of Defense: July 15, 2010

The dissertation of Sharon E. Placide is approved.

Dean Kenneth Furton College of Arts and Sciences

Interim Dean Kevin O'Shea University Graduate School

Florida International University, 2010 


\section{DEDICATION}

I dedicate this dissertation to my grandmother, Dorcas Elizabeth Fraser, who taught me the value of discipline, hard work and perseverance; and to my mother, D. Arlene Walters, who always believed I could accomplish anything - provided I was prepared to work hard enough. 


\section{ACKNOWLEDGMENTS}

I could not have come through this process successfully without the encouragement and support of many individuals. First, thanks to my many friends who helped me recruit participants for this study. Thanks to my closest friend, Cynthia AllenPearson, who because of her mixed racial ancestry by virtue of her white grandfather, and her marriage to a "brown" Jamaican, has been able to provide much insight about color in contemporary Jamaica. I am thankful for my key informant, Dana, who introduced me to the struggles of racially mixed Jamaicans in the U.S. I thank the members of my dissertation group, "Team Mahler," for their honest feedback and advice over the years. Particular mention goes to Team Mahler members, Dr. Anne Braseby, and Tekla Nicolas who never tired of reading my chapters and who challenged my ideas, forcing me to think, rethink, and refine my arguments. I am grateful for the support, advice, and critique provided by my committee: Dr. Alex Stepick, Dr. Jean Muteba Rahier, and Dr. Dionne Stephens. Of course, I am especially grateful for my major professor, Dr. Sarah Mahler, who went far beyond the call of duty in her role as dissertation advisor. Her close attention to my work, her very high standards, and her constant encouragement, have all been invaluable to me. She has been as interested in my well-being as she has been in my professional development. I am extremely thankful, too, for my husband, Seymour: for his inexhaustible patience, for bearing with me through many challenging and uncertain times, and for just being there. 


\title{
ABSTRACT OF THE DISSERTATION \\ NAVIGATING RACIAL BOUNDARIES: THE ONE-DROP RULE AND \\ MIXED-RACE JAMAICANS IN SOUTH FLORIDA
}

\author{
by
}

\section{Sharon E. Placide}

Florida International University, 2010

Miami, Florida

Professor Sarah J. Mahler, Major Professor

Like many West Indians, mixed-race Jamaican immigrants enter the United States with fluid notions about race and racial identifications that reflect socio-political events in their home country and that conflict with the more rigid constructions of race they encounter in the U.S. This dissertation explores the experiences of racially mixed Jamaicans in South Florida and the impact of those experiences on their racial selfcharacterizations through the boundary-work theoretical framework. Specifically, the study examines the impact of participants' exposure to the one-drop rule in the U.S., by which racial identification has been historically determined by the existence or nonexistence of black forebears. Employing qualitative data collected through both focus group and face-to-face semi-structured interviews, the study analyzes mixed-race Jamaicans' encounters in the U.S. with racial boundaries, and the boundary-work that reinforces them, as well their response to these encounters. Through their stories, the dissertation examines participants' efforts to navigate racial boundaries through choices of various racial identifications. Further, it discusses the ways in which structural forces and individual agency have interacted in the formation of these identifications. The study 
finds that in spite of participants' expressed preference for non-racialism, and despite their objections to rigid racial categories, in seeking to carve out alternative identities, they are participating in the boundary-making of which they are so critical. 


\section{TABLE OF CONTENTS}

CHAPTER

PAGE

I. INTRODUCTION 1

Theoretical Framework 4

Rationale for Population and Location of Study 13

Research Methodology and Data Analysis $\quad 14$

Defining Terms 24

Challenges and Limitations $\quad 26$

Chapter Descriptions 28

II. THE SOCIAL CONSTRUCTION OF A RACIAL DICHOTOMY IN THE U.S

Race as a Social Construction 33

Section 1 Race and Mixed-Race During Slavery: The Social

Construction of the One-Drop Rule 36

The Construction of Race During Slavery 36

Miscegenation and the Emergence of the One-Drop Rule 43

Section 2 The Rise and Crystallization of Bright Boundaries 49

Contesting Racial Boundaries: Abolitionists, Free Negroes

and Slaves Oppose Slavery $\quad 50$

White Response: Entrenchment of Racist Ideology 53

Emancipation and Reconstruction Blur Boundaries 56

Southern Whites Defend their Status, Strengthening Racial

Divides

Crystallization of the Bright Boundary: The One-Drop

Rule

62

Mulattoes, Blacks, and Boundary-Work 65

Science Supports the One-Drop Rule 66

Section 3 Blurring Racial Boundaries $\quad 71$

The Civil Rights Movement and its Impact $\quad 71$

The Multi-Racial Challenge to the One-Drop Rule 76

Why the One-Drop Rule Persists $\quad 79$

Chapter Conclusion $\quad 82$

III. THE SOCIAL CONSTRUCTION OF A COLOR HIERARCHY IN JAMAICA

Clarification of Terms: Color and Race

Section 1 Construction of Bright Boundaries: Formation of a

Tripartite Color Hierarchy During Slavery (1655 to 1834)

87

African Slavery and the Beginnings of Race Ideology

87

The Impact of Demography 
Miscegenation, Free Browns, and the Status Mixed

Progeny (Slave and Free) 93

Free Browns Become Buffer 97

Section 2 Boundary Blurring: Color and Social Status from

Abolition to the Independence (1834 to 1962) 100

Loss of Labor and Decline of the White Planting Class 100

Boundary-Blurring Continues: Rise of the Brown Class

And Black Social Mobility 103

Complicating the Color Hierarchy: East Indians, Chinese,

"Syrian" Immigrants 106

Creole Multiracialism Versus Black Nationalism 110

Persistence of a Color Hierarchy 119

Section 3 Boundary-Shifting: Race, Color and Social Status

$\begin{array}{ll}\text { after Independence (1962 to present) } & 120\end{array}$

Boundary-Blurring: Race, Color, and Social Location 120

Color as Symbolic and Social Boundary 124

$\begin{array}{ll}\text { Chapter Conclusion } & 130\end{array}$

IV. OUT OF MANY, ONE PEOPLE: RACE AND COLOR IN JAMAICA 132

Race is Not Important 136

Intersectionality: Class Plus Race 155

Color Draws Boundaries in Jamaica 161

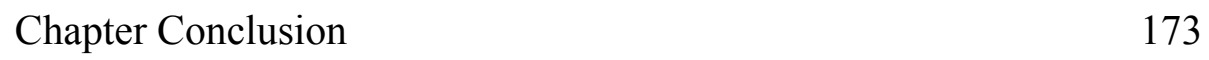

V. ENCOUNTERING BOUNDARIES AND BOUNDARY-WORK

IN THE U.S 175

Race Draws Bright Boundaries in the U.S.: The Centrality of Race

Boundary Maintenance: Two Worlds $\quad 198$

South Florida: Three Worlds? $\quad 207$

Theoretical Discussion $\quad 216$

$\begin{array}{ll}\text { Chapter Conclusion } & 225\end{array}$

VI. NAVIGATING RACIAL BOUNDARIES IN THE U.S. 228

I am Jamaican - Ethnic (Post-Racial) Identification 230

Racial Identification Choices 233

Factors Affecting Jamaicans' Immigrants Racial Identifications 251

Choice or No Choice? The Impact of Structure on Agency and

$\begin{array}{ll}\text { Vice Versa } & 270\end{array}$

Mixed-Race Jamaicans Doing Boundary-Work 276

$\begin{array}{ll}\text { Chapter Conclusion } & 287\end{array}$

$\begin{array}{ll}\text { VII. CONCLUSION } & 290\end{array}$

$\begin{array}{ll}\text { Findings } & 290\end{array}$ 
The Study's Contributions

Limitations and Directions for Future Research
296

299

302

321

332 


\section{CHAPTER I}

\section{Introduction}

Just over 15 years ago I had a memorable racial encounter with a colleague at my place of employment. The encounter involved a conversation with a colleague from another department in the university. This colleague, whom I'll call Miriam ${ }^{1}$, was older than I (probably in her fifties), white, and American. During this conversation Miriam commented on the marriage of another co-worker, June, to a dark-skinned African American male. June was a light-skinned Jamaican female who, because of her light complexion and wavy rather than "kinky" hair, had often been characterized as "Puerto Rican" in the U.S. I learned then that Miriam had objected to this co-worker's marriage on racial grounds. As she put it, "I thought June was white so when I learned she was about to marry Frank I was quite surprised." It was clear that she did not approve of interracial marriages. So I went on to ask her about just that. "Well," she said "it's just that I am concerned about the children. They don't fit in anywhere." I recall being quite puzzled. I did not at all understand what my friend meant by that statement. What did “They don't fit in anywhere" mean? Her statement implied to me that there are specific locations to which whites and blacks are assigned. I did not agree. So I challenged her on that account. But my friend remained adamant that there were two separate worlds: one that was white and one that was black. When people intermarry racially their children suffer as they cannot really belong to either world. My puzzlement and annoyance increased the longer we discussed this topic and so, exasperated, I gave up.

\footnotetext{
${ }^{1}$ Throughout the dissertation pseudonyms have been used to protect the identities of participants.
} 
While this was by no means my first racial encounter in the U.S., it was the first that brought to my attention the existence of firm racial boundaries in this country. I now view it as my first encounter with boundary-work. As I look back on that experience I am intrigued by the difference in our perspectives. They were, of course, the result of the different racial worldviews to which we had been exposed. I had come to the U.S. possessing ideas about race and race-mixing that had been formed in Jamaica. Miriam's ideas about race-mixing were reflecting a worldview she acquired from her American upbringing. It was some time before I was to become aware of certain social realities that reflect these two worlds to which Miriam referred. These realities were described in a recent newspaper article (Chicago Tribune, November 29, 2009). In the article, biracial (black/white) Tamara Field chronicles her experiences with social exclusion and racialization as she grew up. Describing her dilemma she writes, "I'm not that much closer to uncovering my racial truth than I was at Nichols Middle School, where I was warned by black girls that I'd better start 'hanging around with (my) own kind.' I hated and worshiped those girls. I desperately wanted to be considered black enough to hang with them, but I didn't want to give up my white friends to do it." She also describes more recent encounters in her adult years, in particular, comments and questions about the racial ancestries of her two children who possess different hues (her daughter's complexion is much lighter; her son's much darker making obvious his black ancestry.) Her childhood experiences with racialization and social exclusion and the resulting longing to "belong" seem to confirm the concerns my colleague expressed. They suggest that there are indeed separate white and black "worlds." They also illustrate a shared common sense understanding among ordinary people in the U.S. about the importance of 
racial borders. That is, they suggest, that people in the U.S., both blacks and whites, agree that these worlds exist and in their actions make efforts to maintain distinctions that will ensure they remain separate.

My conversation with Miriam reflects a clash of two different racial worldviews a clash that is not uncommon for black immigrants. Scholars (Davis 1991, Benson 2006, Hackshaw 2006, Vickerman 2001, Rogers 2001) in fact, agree that Jamaican immigrants enter the United States with a racial worldview that reflects historical events in their home country, and which differs from that in the U.S. Despite the fact that West Indian territories and the U.S share a history of European colonialism and settlement that depended heavily on the enslavement and denigration of Africans and their descendants, several important trends in the respective societies after emancipation led to differences in their race ideologies. In the U.S., a racial dichotomy developed under slavery that effectively saw to the creation and maintenance of two worlds: a black world and a white world. The U.S. racial dichotomy was the basis upon which the so-called "one-drop" rule evolved. Also called "hypo-descent" by anthropologists (meaning that mixed individuals are assigned the racial identity of the "minority" parent) or "traceable amount rule" by the courts, the one-drop rule has, since the end of the nineteenth century, been the primary means by which racial identification of mixed-race individuals is determined in this country (Davis 1991, Harris 1964, Williamson 1995). Based on the one-drop rule, any individual who was known as having Negro heritage, was considered Negro and relegated to the social position of Negroes - even if that person appeared to be white. Thus, under this racial binary system there have been only two options for racial identification - to be "black" or to be "white." It was Miriam's exposure to this racial 
binary that made her uncomfortable when she believed that our colleague's marriage had crossed racial lines. Significantly, despite black-white mixing in various parts of this hemisphere and other parts of the world, the one-drop rule is unique to the United States (Davis 1991). And while there is evidence in contemporary U.S. society that some mixed Americans are rejecting the one-drop rule in favor of a multiracial identity, the one-drop rule remains the dominant ideology that guides racial identification of the racially mixed.

The one-drop rule has, however, caused consternation among Jamaican immigrants who bear some African heritage but who for socio-historical reasons possess radically different perceptions about race. West Indian societies evolved "racial trichotomies" after slavery consisting of whites at the top, blacks at the bottom, and mixed persons as an intermediate group (Vickerman 2001). Jamaica's racial trichotomy has since evolved into a multilayered color hierarchy that ranks lighter hues over darker ones. This important difference has led to greater fluidity as far as racial identification. That is, black-white mixtures, unlike in the U.S., do not necessarily result in racial identification as black. In short, Jamaica has never developed a "one-drop" rule. Not surprisingly, studies among Jamaicans reveal their feelings of confusion if not consternation at the racialization they experience upon entering the U.S. (Lawrence 1995, Vickerman 2001, Waters 2001). And mixed-race Jamaican immigrants have been startled by their categorization in the U.S. as "black" (Lawrence 1995).

\section{Theoretical Framework}

The race ideology that evolved in the U.S. under slavery and crystallized after Reconstruction was based on essentialist notions that held to the existence of "race" as a 
biological fact. These essentialist ideas have long since been rejected by social scientists in favor of constructivist arguments. That is, there is now general agreement among social scientists that race is a social construction (Daniel 2004, Davis 1991, Dalmage 2000, Gilroy 2000, 2004, Zack 1993). Thus, the dissertation is situated within social construction as the theoretical framework that best explains the evolution of race and the one-drop rule, and the construction of racial identities in the United States and in Jamaica. Following Omi and Winant's (1994:60) theory of racial formation which they define as "the sociohistorical process by which racial categories are created, inhabited, transformed, and destroyed," the dissertation begins by exploring the social and cultural factors that led to the construction in the U.S. of a racial dichotomy in which there were only two choices for racial identification: to be black or to be white. In so doing, it examines how the construction of a racial dichotomy served to reinforce the power structure by maintaining the firm division between those with power (whites) and those without power (blacks). Omi and Winant (1994) point out, that the result of the construction of race in the U.S. was that race became infused into every fragment of the society. Thus, every member of U.S. society is both aware of and subject to the socially constructed rules that guide racial divisions and racial identifications. Everyone "...learns some combination, some version, of the rules of racial classification, and of her own racial identity, often without obvious teaching or conscious inculcation" (Omi and Winant 1994:60).

It is important to note here that rules of racial classification in the U.S. have not always been uniformly accepted or applied across the nation. As the ensuing chapters show, there have historically and still today, always been regional variations and 
dissenters - that is, persons and groups who have rejected the one-drop rule. Moreover, Omi and Winant's racial formation has been criticized for both reifying race (despite their strong assertions in favor of social construction) and its over-emphasis on racial projects (Bonilla-Silva 1997, Loveman 1999). It seems clear from my reading of the literature that surveys the historical construction of "race" in the U.S., however, that most Americans generally both adhere to and reinforce rules of racial categorization that reflect a black/white binary - often unconsciously. Thus, not only has U.S. society been organized historically and contemporarily around racial thinking but, as will be shown, maintaining the distinction between whites and non-whites has become central to the social structure. Despite significant changes in race thinking, that distinction remains important to many in the U.S. today.

In Jamaica, however, race and racial identifications have been constructed differently largely due to demographic differences, and divergent developments in the post-emancipation period. Rather than the rigidity that characterizes a racial dichotomy, Jamaica's complicated color hierarchy has permitted greater fluidity. This more fluid color hierarchy is nevertheless a social construction. Social construction has thus proven to be a useful framework for explaining the evolution of race and racial categories in both countries.

Examination of the data prompted the addition of a second theoretical lens: that of boundary-work. The term "boundary-work" was coined by Thomas Gieryn (1983) who defined it as "an ideological style found in scientists' attempts to create a public image for science by contrasting it favorably against non-scientific intellectual or technical activities" (1983:781). By this definition, boundary-work refers to the creation of lines of 
demarcation that distinguish one group from another. But the lines of demarcation, or boundaries, do more than just distinguish; they establish a contrast that favors those who construct them. Although originally used in reference to science, boundary-work is also applicable to the efforts that social actors make to erect and maintain social boundaries. Boundary-work, then, consists in the conceptualizing of boundaries by which people, practices, and objects are distinguished and separated, and in efforts that people make to see to their perpetuation (Lamont and Molnar 2000, Massey 2007, Sibley 1995).

Scholars in various disciplines in the social sciences have examined boundaries and boundary-work as a means of explaining various social divisions including those that are based on race and ethnicity. Indeed, the study of boundaries has increasingly played a key role in social science research and has been found to be useful in research about collective identity, race and ethnicity, census categories, immigration, groups rights and so on (Lamont and Molnar 2002). The emphasis on boundaries has been found to be useful because it is their persistence through praxis, (that is, through the work of setting and maintaining boundaries) that has ensured the continuation of social divisions.

Academic attention to boundaries can be traced back to the seminal work of Fredrick Barth (1969) who, while writing about ethnic groups, argued for the need to focus on the boundaries that maintain ethnic distinctiveness rather than cultural "stuff" contained within each ethnic group. At the time, anthropologists and other social scientists were primarily focused on the "stuff" of culture and asserted the independence of cultures by treating them as wholes, but rarely addressed the issue of how people delineated themselves from others - boundary work. While the cultural features and even membership of an ethnic group may change, Barth wrote, "the nature of continuity 
of ethnic units is clear: it depends on the maintenance of a boundary" (Barth 1969: 14). More recently, sociologist, Richard Jenkins (2004) argued that identifications (a term he prefers over "identities") are determined and negotiated at their boundaries. That is, they are determined at the juncture that divides between "us" and "them" - those who belong to a particular group and those who do not.

Lamont and Molnar (2002), who provide a comprehensive overview of scholarly literature in the social sciences emphasizing boundaries, have devised a distinction between "symbolic" and "social" boundaries that is pertinent to this dissertation. This distinction, they argue, encapsulates a thread that runs through the entire literature on boundaries. Symbolic boundaries, they assert, consist in "conceptual distinctions made by social actors to categorize objects, people, practices, and even time and space... Social boundaries are objectified forms of social differences manifested in unequal access to and unequal distribution of resources (material and nonmaterial) and social opportunities" (Lamont and Molnar 2002: 168). Thus symbolic boundaries are the ideas that people have about phenomena that guide the ways in which they go about actually categorizing them. When these conceptual distinctions are widely shared and practiced they translate into rigid, systematic, and carefully patrolled patterns of social exclusion (and inclusion). Race and the one-drop rule are both constructed based on symbolic boundaries that through vigorous boundary-work are transformed into social boundaries. While as will be shown later, the act of categorizing is a natural inclination of humans, the act does not always result in social inequality (Massey 2002). It always, however, results in the creation of distinctions that determine in-groups versus out-groups (Massey 2002, Jenkins 2004). 
Boundaries are often erected based on feelings of similarity and difference, since boundaries at once include by creating communities, and exclude by inventing the "other." Boundaries also serve as means of defining one's identity as is exemplified by the one-drop rule. Moreover, they serve to rank and stratify groups as will become evident the ensuing discussions of the U.S. racial dichotomy and Jamaica's historical racial trichotomy. In this way, boundaries become so significant that to attempt to cross them is to threaten the social order which they create. The threat is perhaps felt most severely in the case of racial boundaries which are based on essentialist notions that hold racial lines to be fixed and permanent. As Dalmage (2000:35) argues:

Borders give each person a sense of ourselves, in the world; they help us know where we fit, what our status is, and who our people are. They teach us what is significant in society. The borders maintain the shape of the category and are meant to stop one category from leaking into the next...When borders are crossed, essentialist explanations are threatened. Ultimately, borders maintain the color line and the strength of race by making race appear natural.

The boundary-work framework, as will be shown, essentially re-packages wellknown social science concepts such as "power," "structure and agency," "diversity," and "sameness," and so on, that are typically not packaged in such a succinct manner, by emphasizing the efforts which humans make to construct and maintain boundaries (in this case, racial boundaries) in order to establish and reinforce the social structure. As such boundary-work is the theoretical framework which is most appropriate for both the background to and the outcomes of this study. The histories of race in both countries are 
histories of social construction and their racial systems are socially constructed. But those racial systems were constructed through boundary-work that aimed to erect and maintain social systems organized around the idea of race. Thus in both the U.S. and Jamaica, strata have been constructed through boundary-work. Boundary-work highlights the construction of rigid racial boundaries in both territories. Boundary-work explains the reinforcement of those boundaries through the one-drop rule after the Civil War, and it explains post-Civil Rights border-patrolling that still characterizes race relations in the U.S. Boundary-work also explains the construction of different types of borders in Jamaica especially after emancipation. Thus, it is through boundary-work that racial lines were drawn and through which they have historically been maintained and/or revised. Moreover, boundary-work best helps explain how racially-mixed-Jamaicans recognize racial boundaries in the U.S. and the efforts they make to navigate these boundaries.

The dissertation also highlights distinctions between "bright" and "blurred" boundaries, concepts that were introduced by Richard Alba (2005) in his analysis of the nature of boundaries and the processes that affect them. Alba (2005) argues that the emerging literature on boundaries has not given enough attention to the fact that boundaries are not all alike. Some boundaries, he asserts, are bright. But this he means that, "the distinction involved is unambiguous, so that individuals know at all times which side of the boundary they are on. Others are 'blurry,' involving zones of selfpresentation and social representation that allow for ambiguous locations with respect to the boundary" (Alba 2005:22). Bright boundaries are rigid and therefore impermeable; blurred boundaries are less rigid, and thus likely, more permeable. The dissertation argues that boundary-work in both the U.S. and Jamaica has resulted in bright and blurred 
boundaries at various junctures in their respective histories. In both countries, bright boundaries have determined groups' social locations. And in both, various factors including opposition from disenfranchised groups have led to blurry boundaries that permit mobility across formerly rigid lines.

Also useful here is Aristide Zolberg and Litt Woon Long's typology of boundaryrelated processes (Alba 2005). The typology identifies three possible types of changes to boundaries which help explain how their impact on individuals and groups, and social hierarchies are transformed. The first, boundary crossing, involves assimilation or incorporation in the desired group on an individual level. While individuals move from one group to another, there is no change to the boundary itself. The second, boundary blurring, involves changes to the parameters of the boundary so that social distinctions between groups become less clear. In this way individuals' social location with respect to the boundary may be less definite. The third, boundary-shifting, involves relocation of a boundary permitting entry of previously excluded groups. All three processes have been relevant to the histories of race and race-mixing in both countries.

While the act of placing phenomena into categories does not necessarily result in the establishment of social hierarchies, it is the latter that was behind the evolution of race ideology, and the main force prompting the creation of the one-drop rule. Thus the rule, though a social construction, has essentially served as the bright boundary that, in the U.S., has solidified the distinction between those who are white and those who are not. Clarification and reinforcement of the distinction between whites and non-whites is essential if a social structure in which whites are dominant is to be maintained. 
The primary framework for the dissertation is thus boundary-work. The utility of the boundary-work framing becomes even clearer when one considers the ascription by scholars of boundary-work to a propensity among humans for placing phenomena into categories (Lamont and Molnar 2000, Massey 2007, Sibley 1995). According to their argument, human beings have a natural inclination for thinking in categorical terms and for dividing the world into conceptual categories. People use conceptual maps to evaluate themselves, the social roles, and the social groups and individuals they encounter (Massey 2007). Categorizing and stereotyping are tools that people use in order to adapt to their environment (Lamont and Molnar 2002). People are, in fact, hard-wired to construct categories into which they place various phenomena. Thus, this is a natural, innate tendency that all humans have - a need to place phenomena into categories in order to understand the world (Massey 2007, Sibley 1995). Given this argument it cannot be said that only dominant social classes engage in such efforts. All sectors of human societies must therefore be engaged in the work of constructing and maintaining borders. This fact is illustrated in the histories of racial formation in the U.S. and Jamaica. The idea of "race" and the accompanying racial lines and social structure were not invented by dominated groups; rather they were erected by the powerful to demarcate themselves and to preserve their privilege. As time passed, however, dominated groups have participated in their own versions of boundary-making and of boundary-maintenance. The argument that all humans possess the tendency to engage in boundary-work therefore has implications for the population under study. It is these implications that the dissertation explores. 


\section{Rationale for Population and Location of Study}

Despite interracial mixing in various parts of this hemisphere and other parts of the world, the one-drop rule is unique to the United States (Davis 1991). Scholars note a much greater degree of fluidity in racial identification for racially mixed individuals in other countries (Davis 1991, Harris 1964). Davis (1995), for example, identifies five different models for racial identification of mixed-race individuals in Vietnam, Canada, Mexico, the West Indies and Haiti. Since the 1965 Immigration and Nationality Act opened the doors to migration from non-European sources in Asia, Africa, Latin America and the Caribbean, the U.S. has received large numbers of immigrants, among them Jamaicans, with more fluid notions of race. While a great deal of attention has been given to immigrants from Asia and Latin America, it is only since the last decade of the twentieth century, that scholars have begun to turn their attention to black immigrants (Waters 1999a).

Jamaicans are among the large and growing population of black immigrants whom scholars surmise are likely to significantly impact traditional assumptions about the meaning of race and blackness in the United States, since these immigrants hold racial worldviews that derive from different histories in their home countries (Davis 1991, Benson 2006, Hintzen 2003, Rogers 2001, Vickerman 2001). In fact, Jamaicans have contributed to a large percentage of the total growth in the immigrant population (Buddington 2002). According to U.S. Census 2000 figures, there were 553,825 Jamaicans in the U.S. - some 18.8 percent of the total Caribbean-born population. Jamaicans thus constitute the third largest Caribbean immigrant group following Cuba and the Dominican Republic and the largest from the English speaking Caribbean. It has 
already been shown that while Jamaica and the U.S share a history of European colonialism and settlement that depended heavily on the enslavement and denigration of Africans and their descendants, several important trends in the respective societies after emancipation have led to the evolution of different racial ideologies (Vickerman 1999). Black immigrants are viewed as contesting traditional notions about the meaning of race in the U.S., their importance lies in their increasing numbers as well as the fact that they hold different understandings of race (Davis 1991, Benson 2006, Hinzen 2003, Vickerman 2001). Since Jamaicans have contributed significantly to growth in the black immigrant population in the U.S., it is important that their experiences and their reactions to racialization in the U.S. be thoroughly explored.

South Florida contains a large Jamaican immigrant population. In fact, South Florida hosts the second largest Jamaican immigrant population after New York. According to the Census 2000 there were 141,182 foreign born from Jamaica in Florida comprising 25 percent of the total Jamaican immigrant population. Of this figure, 89.9 percent $(127,020)$ resided in Miami-Dade, Broward and Palm Beach counties. Despite the relatively large Jamaican immigrant population in South Florida, very few studies related to West Indians and race, have been done among this group (Kasinitz 2001, Jones $2005,2008)$. None of these studies has focused on mixed race identity.

\section{Research Methodology and Data Analysis}

Since there have been no previous studies on racial identification among mixedrace Jamaicans, this is an exploratory study rather than one that tests formal hypotheses. The study aimed to explore the impact of participants' exposure over time to the racial 
worldview encountered in the U.S. on the ways in which mixed-race Jamaicans identify themselves racially. The study thus asks the following research questions:

1. What is the impact of U.S. racialization experiences on the racial selfconceptualizations of mixed-race Jamaicans in South Florida?

2. How does exposure to different ideas circulated within formal and informal social networks and by the media, affect the racial labels used by Jamaican immigrants?

The goal of these questions is to examine the impact of exposure to the "one-drop" conceptualization on how participants think of themselves racially. That is, if asked to what "race" they belong, will participants use "mixed," "white," "black," or some other term? The first question focuses on the impact of racialization and racism on the racial labels that my interviewees currently apply to themselves. The objective of the second question is to examine the influences, above and beyond racialization, on the racial labels respondents apply to themselves. Do respondents whose primary social networks are Jamaican use different racial labels for themselves than those whose primary social networks are not Jamaican but African-American, Hispanic etc.?

I had also intended to explore the impact of length of residence on racial selfcharacterizations. The recruitment of a convenience sample, however, resulted in too few participants with short periods of U.S. residence. This factor therefore could not be explored.

\section{$\underline{\text { Target Population }}$}

The target population consisted of first-generation Jamaican immigrants residing in South Florida. My goal was to recruit Jamaicans who were adults when they immigrated and who therefore entered with a racial frame of reference that reflects their 
Jamaican upbringing. In an effort to mitigate confounding factors, original research design included a carefully selected sample with biracial participants with African and European ancestry only. Participants would be between the ages of 18 and 40, and residents of Miami-Dade, Broward and Palm Beach counties in South Florida.

\section{Challenges and Modified Research Design}

It proved difficult, however, to recruit sufficient participants who met all the criteria. Significant intermixing among various racial groups (blacks, Chinese, Indians, Lebanese, whites) in Jamaica combined with the declining white population prohibited recruitment of individuals with only black and white ancestry. I therefore recruited a convenience sample by expanding the criteria to include individuals with multiple racial ancestries. The result of this change was a much more varied sample. All participants were racially mixed Jamaicans with black ancestry as Table 1 demonstrates. While some were first generation biracials with one parent of black ancestry and one parent of white, Chinese, or Indian ancestry, others were offspring of multiracial parents (see Appendix 1). Most participants were first-generation immigrants; three were of the 1.5 generation. They were born in Jamaica arrived in the U.S. between the ages of 8 and 15. And two participants were brothers who had been born in the U.S. but had been taken to the island as babies and raised there. They left the island at the ages of 12 and 8 respectively. The fact that the latter brother returned to the island many times during the remainder of his childhood as well as adolescence afforded him extended exposure to race and race thinking on the island. Thus, although a few participants were not in fact first-generation Jamaicans, all had spent their childhood and part of their teen years in Jamaica and all therefore had their ideas about race formed on the island. They thus all had a dual frame 
of reference as far race and racial identification. While participants were multiracial with varying racial ancestries, all reported having black ancestry.

Table 1

\begin{tabular}{|llcccc|}
\hline & Total & Black/White & Black/Chinese & Black/Indian & Multiracial \\
\hline Total & 34 & 10 & 1 & 3 & 20 \\
\hline Male & 16 & 6 & 1 & 1 & 8 \\
\hline Female & 18 & 4 & 0 & 2 & 12 \\
\hline
\end{tabular}

I recruited respondents by multiple snowballs, beginning by establishing contacts in various Jamaican churches and organizations in South Florida. Using one standard letter that was distributed largely by email, I described the study and the criteria participants needed to meet. I also sought the assistance of a number of personal acquaintances - particularly those who were themselves racially-mixed Jamaicans. I attended various events hosted by Jamaican organizations. In addition, I created a Facebook group and invited various Facebook friends to join the group and invite individuals who either met the criteria or would likely be acquainted with someone who did. I also recruited participants from referrals made by focus group participants and interviewees.

Knowing from experience that some Jamaicans who appear based on phenotype to be racially mixed, self-identify as "black" and may therefore be discouraged from participating in the study, I devised a measure of racial identification that included a screening questionnaire for prospective participants. The questionnaire asked specific questions about racial ancestry as far back as great-grandparents, requesting that individuals list the various heritages that compose their ancestry allowing for the 
selection of respondents regardless of the manner in which they self-identified. I issued the questionnaire to individuals who indicated their interest in participating in the study. As was done in another study (Clinton 2006), I also applied a standard visual evaluation of "mixed" phenotype that uses skin color, various hair textures and fine/thin facial features that are typically associated with people of mixed African-European descent, to select respondents. The latter strategy was particularly useful when I attended Jamaican events in search of possible respondents.

Every effort was made to recruit equal numbers of men and women and the final sample contained 16 males and 18 females. It was expected that the recruitment of equal numbers of men and women would facilitate an examination of the additional impact of gender on the experiences encountered by mixed-race Jamaicans. It has been wellestablished, for example, that since physical appearance is generally overvalued for women, mixed-race women are "particularly vulnerable to society's reactions to their ambiguous features" (Root 1997). To mitigate possible confounding factors, the study also controlled for similar socio-economic status measured by highest level of educational attainment that is: some college or college graduate.

\section{Data Collection}

The research began with a focus group meeting of five participants, two males and three females. Through the focus group I aimed to elicit racial labels Jamaicans use for themselves and what they signify, and to explore the various experiences respondents have had with racialization in the U.S. and the various ideas they hold about racial identification. Focus groups dynamics facilitate discussions that quickly identify the range in variation of ideas on topics. The expectation was that the discussion would 
reveal a variety of stories about participants' experiences with racialization, various reactions to such and how such experiences have influenced participants' racial selfcharacterizations. The focus group also provided the opportunity to test interview questions.

The core of my data, however, came from one-on-one semi-structured interviews with 34 additional respondents. Interviews were designed to collect information on (1) self-identification and (2) demographic details (such as age, sex, residence). Interview questions addressed thus ideas respondents hold about their own racial identification and sought to glean factors that might affect identifications. Interview questions generally asked about racial experiences in Jamaican, U.S. racial experiences, racial discourse among family and friends. Participants were asked how they identified themselves racially at the time of the interview, whether their racial identification had changed since entering the U.S. and, if so, why. Questions also addressed social networks, in particular the racial/ethnic backgrounds of the people with whom participants spend time for leisure and the ideas to which they have been exposed while relating to such (see Appendix 2 for details).

In order to evaluate the degree to which a mixed identity is important to respondents, I also employed a survey as part of the research protocol. Although this is primarily a qualitative study, the survey, which asked questions about participants' racial identification choices in Jamaica, in the U.S., and about their racial identifications in specific contexts, was designed to explore whether there was consistency between the results from both the interviews (qualitative) and the scale (quantitative). It would also provide initial data on racial identifications in Jamaica and in the U.S. and point to any 
evidence of changes in identifications. If there were inconsistency, the idea was to explore that with subjects. The qualitative data was expected to enhance understanding of racial identifications by eliciting not only these identifications but also explanations for these identifications. This instrument was distributed online using SurveyMonkey.

During the data collection phase I developed a relationship with a participant who invited me to attend social events with his family and friends. Such events were invariably attended largely by West Indians - almost all of whom were Jamaican and racially mixed. These occasions thus turned into opportunities for observation of the performance of identifications among mixed-race Jamaicans. Since this participant's brother had also been a study respondent, I was able to also observe the behavior of both in regard to identifications beyond the context of the interview itself. Doing so proved useful especially given the fact that identifications are often multilayered and situational - changing from context to context. The opportunities to view these respondents in their "naturally unfolding worlds" (Berg 2004:129) enhanced my ability to understand and interpret data gleaned from their interviews. ${ }^{2}$

Interviews were held in locations that were convenient to participants including their homes, offices, and public spaces such as Barnes and Nobles Bookstore and Starbucks. At the beginning of each interview, I made every effort to take notes describing the participant's physical features (skin tone, hair texture, if discernible, facial features) and, if time permitted, the physical environment. As I observed their physical appearance, I especially noted whether in my estimation, participants' black ancestry was

\footnotetext{
${ }^{2}$ Data from my interviews do point to the multilayered and situational nature of racial identifications. The above-mentioned experiences, however, highlighted how observation outside of a formal interview might reveal additional dimensions to respondents' reported identifications.
} 
visible. I had already determined that phenotype would likely impact upon participants' experiences which would, in turn, likely impact on their racial identifications. Where necessary, interviewees were contacted by email after the interview for the purpose of clarifying interview responses.

Data Analysis

The focus group discussion was recorded and the recording transcribed shortly after the meeting and stored for analysis in MAXQDA data analysis software that facilitates detailed and systematic text analysis. I reviewed the transcript several times carefully examining the document for patterns in the data and examined deviations from such patterns. Doing so helped me to identify topics that appeared to be important to participants early in the analysis process. I carefully noted these topics through a process of memo-making that allowed me to document my thoughts and observations about them. Since the focus group recording was transcribed and reviewed before I began conducting interviews, themes identified at this early stage served proved useful as I began to conduct and transcribe interviews.

Interviews were also recorded and transcribed as soon as possible after each meeting and stored for coding in MAXQDA. Doing so permitted a more grounded theory approach, one apropos when no similar research has been done (Charmaz 2001). I transcribed the focus group recording as well as one-third of the interview recordings and hired two transcriptionists to complete the rest. I carefully examined transcripts as they arrived to ensure that they accurately reflected recordings and made corrections as needed. This step was necessary particularly since one of the transcribers was not 
Jamaican and at times was not able to accurately document stories or comments that were communicated had been in the Jamaican patois.

Since the primary goal of the study had been to explore the influence of various types of exposure over time on racial self-characterization, I examined the text bearing in mind the previously mentioned dimensions of exposure and their indicators noting any patterns that pointed to their impact on racial self-identification. Early in the analysis process it became clear that the impact of length of residence could not be examined since there were too few participants who had had lived fewer than six years in the U.S. However, the remaining three dimensions of exposure (informal exposure, formal exposure and the media) were carefully explored. Also explored was the impact of other factors such as phenotype (hair texture and skin color), socialization, and family racial identity that had already been identified by previous studies (see for example, Brunsma 2005, Rockquemore 1999, Rockquemore and Brunsma 2008, Roth 2005) as having an impact on racial identification choices were also explored.

Thus my analysis combined inductive approaches that are appropriate for grounded theory with deductive approaches that responded to my research questions. First, I carefully reviewed six randomly chosen transcripts and while doing so created memos that documented my thoughts about participants' responses and identified key concepts that seemed to be emerging from the data. Concepts that had been detected during the focus group proved helpful as points of departure. Following Corbin and Strauss (2007) this early stage of analysis involved also pre-coding or the creation of initial codes based on concepts that recurred in these transcripts. "Privilege" and "loss of privilege" are examples of concepts that emerged during that early period of data analysis 
and that appeared to be important to participants. These topics were later converted into a code and sub-code. Code memos were created to describe the purpose and meaning behind each code as well as the parameters within which each would be used. While reviewing these transcripts I also continued to write memos, that is, notes documenting my thoughts about these key concepts. Memo-making permitted both documentation of these topics and exploration of specific characteristics (such as sex, age, phenotype) borne by participants who raised them. The goal was to work toward greater abstraction so that these concepts (referred to as lower-level concepts) might be subsumed under higher level concepts or themes. Additional memo-making permitted the documentation of similarities and comparisons related to these themes. That is, they permitted notetaking about how participants approached each theme noting factors about participants that might explain their emphasis on specific topics. Memo-making also facilitated examination of relationships among themes. My goal was to achieve a high level of saturation, that is, to ensure that all important concepts had been thoroughly examined, and analyzed, organized into themes and sub-themes and that no new themes were found. The latter assisted in revision of the initial list of codes and in the construction of an organized codebook. As the remaining transcripts became available and were reviewed, codes from the codebook were assigned to the text where they were applicable. This process also involved renaming and reorganizing of codes to represent concepts that more aptly represented participants' thoughts about various topics. Thus this was not a unilinear process; rather, my analysis involved a recurring process of revisiting and expansion of memos based on new information as well as the revision and refinement codes to better reflect important themes. 
My analysis was aided by the examination of the texts through demographic variables (attributes in MAXQDA). Doing so permitted the comparison of texts and text segments by, for example, women versus men, by people based on their age, and also on their years of residence in the U.S. In this way I was able to examine systematically the impact of these factors on participants' experiences and on their racial selfidentifications. Racial identification choices in Jamaica and the U.S. were also converted into attributes. The creation of attributes facilitated use of MAXQDA's visualization tools as well. For example, I was able to create crosstabs of specific codes and attributes (variables) to examine possible relationships. The use of visualization tools--akin to graphing quantitative data--was helpful as I sought to discern patterns (frequently occurring answers and correlations between those and specific factors) in the data.

Data collected from online surveys was compared against patterns that emerged from interviews for similarities and differences and for what they might signify. In particular, I examined patterns in identification choices in the U.S. paying special attention to the impact of memories of Jamaica, phenotype, racial experiences in the U.S.

\section{Defining Terms}

Rockquemore and Brunsma (2008) argue that scholars of racial identity face persistent difficulties with the clarification of labels and terminology. Her argument resonates with my experience. During virtually every stage of the composition of this dissertation, I grappled with the need to clarify in my own mind the meanings of various terms. My confusion was only increased by encounters with literature that used some terms (for example, "race" and "color") interchangeably. Yet, as Rockquemore and 
Brunsma (2008) point out, to conduct empirical research on the experiences of racially mixed individuals and their impact on racial identification choices it was important to be clear about the meanings of these terms.

In this dissertation "racial identification" has been chosen rather than "racial identity" as the focus of the study. The choice was based on an understanding of racial identity as referring to deep, foundational understandings that people have of themselves based on race (Brubaker and Cooper 2000, Rockquemore and Brunsma 2008). In this way racial identity refers to feelings that people have of themselves as reflected in statements such as "I feel black." Racial identification refers to racial labels that people apply to themselves or that they report are applied to them. While these identifications may in fact be related to deep feelings of identity, the study does not explore these deeper feelings. Brubaker and Cooper write that while the term "identification" lacks the "reifying connotations of "identity" it requires specification of who does the identifying. Moreover, they write that identification,

...does not presuppose that such identifying (even by powerful agents, such as the state) will necessarily result in the internal sameness, the distinctiveness, the bounded groupness that political entrepreneurs may seek to achieve. Identification - of oneself and others - is intrinsic to social life...(Brubaker and Cooper 2000: 14).

In this way, identification is a dynamic term, one that accounts for and allows for consideration of the impact of factors and players on the assignment of labels, as well as variation among individuals and across contexts. As such it is much more apropos for a 
study that is about the impact of changing contexts on the racial labels that individuals apply to themselves. This is a primary concern of this dissertation.

\section{Challenges and Limitations}

One challenge I experienced during the course of this study was related to the fact that I am Jamaican. I do not consider myself to be racially mixed; however the fact that I am Jamaican made me to some degree an "insider." While participants described experiences that are specific to individuals with mixed racial ancestry (for example, exposure to large numbers of family members who were not black) with which I could not identify, as a Jamaican, I found myself agreeing with many of the perspectives they shared about both race in Jamaica, and in the U.S. Being an insider proved advantageous in many respects. First, I was able to take advantage of my "insider" status as a Jamaican in order to gain entry into the community under study. In both written and telephone communications with possible recruits for the study, I made certain to indicate that I was Jamaican. Second, although English is the official language of Jamaica, participants often switched into the less formal patois in the focus group and interviews. I generally had no difficulty understanding the patois and also often understood deeper meanings of certain terms in ways that a non-Jamaican might not have. This fact facilitated transcription of recordings as well as corrections of errors in those that had been transcribed by someone else. Additionally, I recognized various locations, schools, and institutions in Jamaica that participants mentioned or described in their responses and had immediate understanding of their contextual meanings. For example, participants often named specific locations in stories of their experiences in Jamaica. While to protect participants' identities I have not named those locations in the dissertation, I understood the 
implications of having lived in an area that is known to be host to large numbers of middle-class Jamaicans versus one in an urban area in which lower-income families typically live.

However, my insider status as a Jamaican also led me to make assumptions ${ }^{3}$ that proved problematic during data collection, analysis, and writing. I found that as I listened to recordings and read transcripts, there were times in which I might have probed for more information about a particular perspective or experience had I not assumed that I understood certain meanings behind participants' stories. And during analysis I sometimes interpreted responses based on my own perspectives - especially about Jamaica. To counter the first challenge, I contacted respondents subsequent to interviews and sought clarification as needed. And to respond to the second, I revisited the data to ensure what I reported reflected participants' responses rather than my own assumptions and impressions. I also often shared pieces of the data with colleagues who are not Jamaican and sought their interpretations as well. Doing so sometimes resulted in changed interpretations and conclusions. At other times my efforts resulted in confirmation.

As is common with exploratory research the sample was small and, due to recruitment challenges, more varied than I had originally intended it to be. Since this is a qualitative study, it had never been the intention to make inferences with claims to

\footnotetext{
${ }^{3}$ Researchers who are not members of the community they are studying do also, of course, make incorrect assumptions. Zinn (2001) has shown, for example, that researchers of minority groups who are members of dominant groups often report on the lives of minorities from a viewpoint that influences the quality of the data that is produced. All researchers face challenges regardless of their relationship with the group understudy and all must then employ strategies to ensure that their conclusions closely follow the data and that bias has been avoided, as I indicate above.
} 
representativeness. Moreover, since the sample contains various possibly confounding factors (for example, participants have different combinations of racial ancestries, some are first generation biracial, others children of multiracial parents) it is difficult to examine the impact of such factors on racial identification choices. This study thus makes no pretense at either generalizing the experiences of racially mixed Jamaicans or providing thorough explanations for findings. Rather, it highlights and describes the experiences and perspectives of these 34 participants and raises questions that will lead to further study of this important group of West Indian immigrants. Nonetheless, the study's findings are likely to apply more broadly than to the mere sample of people I researched. I just cannot assert this connection, a limitation of all exploratory research.

\section{Chapter Descriptions}

What follows therefore is a discussion of the major themes that emerged from interviews with study participants. Divided into two parts, it begins in part one with a historical overview that traces the factors that led to the erection and maintenance of racial boundaries, the most rigid of which was the one-drop rule, in U.S. society and those that led to a different type of social construction of race and racial identification in Jamaica. This part thus discusses the factors that led the development of different race ideologies in the U.S. and Jamaica (racial dichotomy versus color hierarchy). It discusses post-Civil Rights developments in the U.S. that have placed pressure on the U.S. racial dichotomy and the factors that foster its perpetuation.

Divided into three chapters, part two discusses the data findings from my focus group and interviews. Chapter four describes and analyzes informants' memories of Jamaica and their stories about race, racial identity, and racial categories in their home 
country. It outlines and analyzes participants' comments about race in Jamaica and its relationship to class. It examines their memories of the place of racially mixed Jamaicans in the society and of their own experiences there as racially mixed individuals. It argues that those memories impact on how participants respond to their racial experiences in the U.S. and in turn on how they navigate racial boundaries in United States.

Chapters five and six describe participants' stories about their racial experiences in the U.S. and their responses to them. These chapters are important as they address the main focus of the dissertation, that is, participants' U.S. racial experiences and the impact of those experiences on participants' racial self-identifications. Using their stories, chapter five discusses participants' encounters with racial boundaries in the U.S. It highlights their perspectives about the salience of race in the U.S. as reflected in their experiences with racism and racialization, and their encounters with rigid racial categorization, thereby showing how, in the U.S., boundaries have been drawn around them. It argues that while for the most part their comments are not very different from those that have already been cited by previous studies of West Indians, their racially mixed background leads to experiences and perspectives that are not really addressed in the racialization literature. The chapter also deals with participants' descriptions of the peculiarities of South Florida, the location of the study. The chapter introduces boundarywork theory as the framework that best explains participants' stories of their experiences and their reactions to such.

Using both survey and interview data chapter six focuses on how participants navigate the racial boundaries which they encounter in the U.S. That is, it explores the measures respondents employ to respond to boundary-work in the U.S. The chapter is 
divided into two sections. The first explores patterns of racial self-identification; the second explores the factors that explain these patterns, focusing in particular, on the impact of participants' various experiences with racialization. Responding to the research questions, the chapter also examines the impact of three dimensions of exposure (informal exposure, formal exposure and the media).

Especially since the 1990s there has been increasing interest in the experiences of West Indian immigrants to the United States. Considerable research and theorizing have focused on the impact of race on immigrant incorporation as well as on questions of racial identity and black subjectivities (see for example, Foner 2001, Hackshaw 2006, Hintzen 2001, 2004, Hinzten and Rahier 2003, Johnson 2008, Rogers 1999, Vickerman 1999, 2001, Waters 1994, 1999). Previous studies about race and West Indian immigrants have not, however, focused on the experiences that are particular to racially mixed West Indians and none have studied racial identification among mixed-race Jamaicans in South Florida (Benson 2006, Brettell 2007, Foner 2001, Hackshaw 2006, Rogers 1999, Vickerman 1999, 2001, Waters 1994, 1999). This study thus provides an important contribution to the literature by describing these experiences and by highlighting the perspectives of this important group of immigrants. There is, moreover, increasing interest in the experiences of mixed-race people in the United States as is evidenced in the proliferation of scholarship on their various experiences (see for example, Clinton 2006, Dalmage 2000, Rockquemore and Brunsma 2008, Root 1997, 2001, Roth 2005, Sollors 2001, Williams 1996, Zack 1993, 1995, 1997). This study, therefore, also contributes to the expansion of our understanding of the ever-growing and increasingly 
more complex population of multiracial people in the U.S., a population that is most likely to bring forward a post-racial society. 


\section{CHAPTER II}

\section{The Social Construction of a Racial Dichotomy in the U.S.: the Rise and Rule of the One-Drop Rule}

This chapter outlines the social and political factors that led to the construction of the one-drop rule, as a bright boundary in the United States. It examines the ways in which essentialist ideas about white racial superiority shaped Americans' attitudes toward black-white miscegenation and how racial boundaries were constructed and patrolled in order to establish and maintain a status quo that favored whites. Boundaries that are erected for the purpose of social stratification are often contested. Therefore the chapter also examines the forces that have at various junctures aimed to dismantle racial boundaries, and it discusses the efforts that whites, and later blacks, have made to reinforce them.

An understanding of the evolution of the concept of race itself serves as an important background to this discussion. The history of the social construction of race is, however, long and the literature that covers it both vast and complex. It is difficult to provide a comprehensive overview in one chapter of a dissertation. Therefore while briefly addressing the evolution of race in the context of slavery, the main goal of this chapter is to emphasize key moments in racial boundary-making in three long eras: the early colonial period through pre-Revolutionary years; the Antebellum period through the early $20^{\text {th }}$ century; and Civil Rights to the present. While doing so, it accentuates changes in race-thinking during each era and the relationship between such changes and attitudes toward black-white miscegenation. Race-mixing between blacks and whites is central to 
my discussion, because by its very nature, it requires transgression of racial boundaries that for centuries have been considered fixed, and important (Dalmage 2000, Holt 2004, Spickard 1989). The existence of transgressors (those who engage in interracial unions and the children who are born of such unions) challenges such notions even if they do so merely by existing and not by their actions. Their existence also challenges the imagined "purity" of the races and assumptions about racial hierarchies. And it is for these reasons that U.S. individuals (like my co-worker Miriam whom I mentioned in the previous chapter) and groups have performed boundary-work to ensure that racial groups are kept separate.

A primary focus of this chapter is the historical boundary-work that resulted in the construction of the one-drop rule, which since the middle of the 19th century, has been the basis for determining racial identification in the U.S. (Davis 1991, Harris 1964, Williamson 1995). Through this rule, mixed offspring have been identified as "Negro" or "black" based on any traceable amount of Negro "blood" regardless of physical appearance (Nagel 2003, Johnson 2003, Zack 1993). The rule consolidated the distinction between whites and blacks, and has functioned as a bright (unambiguous) and impermeable racial boundary in the U.S.(Alba 2005).

\section{Race as Social Construction}

Race is a modern idea that was created as a new axis of social differentiation during European expansionism and colonization of the New World and under the institution of slavery (Alleyne 2002, Daniel 2004, Gossett 1963, Sanjek 1994, Smedley 2007). Based on popularly held essentialist beliefs in the existence of biological 
differences among racial groups, the idea of race evolved as part of the European colonial project and was essential for the creation and maintenance of a social order by which whites held blacks in subjection. These essentialist ideas held that races were determined biologically, that they are therefore innate, and that biology not only controls phenotypical features but also more intangible characteristics such as intelligence, propensity toward violence, etc. (Dalmage 2000). Aided by naturalists, Europeans thus established a system of racial classification under the colonial project that was used to justify the rigid borders that, especially in the U.S., separated blacks from whites. As the chapter shows, racial essentialism rested on the assumption that racial categories were fixed and inalterable (Dalmage 2000, Zack 1993, 1995). These ideas found support in the racial classifications provided by scientists and in polygenist beliefs in the separate origins of race that came to be widely propagated in the nineteenth century (Gossett 1963, Gould 1981, Smedley 2007). And in the 19th and 20th centuries various studies (beginning with research that studied cranial capacity and continuing with intelligence testing) were conducted prove that the white race was superior to all others in intelligence (Gould 1981). These ideas were popularized in the U.S. providing additional support for already existing folk beliefs in the innate inferiority of Africans and their descendants.

Most social scientists and other scholars have long rejected notions of race as a biological fact in favor of social constructivist arguments (Daniel 2004, Davis 1991, Dalmage 2000, Dunn 1975, Gilroy 2000, 2004, Zack 1993). They argue that race is a social construction that has been erected through "human interaction and struggles for power" (Dalmage 2000: 11; see also Davis 1991; Grillo 2003, Haney Lopez 1996, 2003, Omi and Winant 1994, Smedley 2007, Zack 1993, 1995). As a socially constructed axis 
of differentiation, race is a human categorical scheme that serves, among other such schemes, to organize humans into groups and then to rank or stratify those groups (Massey 2007). In the case of race, the organization is based on visible phenotpyical characteristics that have a strong basis in biology but do not create biologically superior and inferior groups. Rather, notions of ranking are superimposed socially. Under social construction theory race is neither fixed nor inalterable and racial categories are fluid and change over time (Haney Lopez 2003). Thus, while today people have become accustomed to assigning an inferior social ranking to those with darker skin and other African features, in the future this could be reorganized around any physical feature or around features that are not physical. The decision of the feature used to categorize and stratify depends upon those people in power who can determine the basis for the lines that divide society. These people typically choose categories that favor themselves and defend them via boundary-work.

Therefore, while essentialism guided the formation of race and racial categories, the histories of race and mixed-race both in the U.S. and in, as discussed in the next chapter, Jamaica are really examples of social constructions. Indeed, the largely historical sections of this and the following chapter are in and of themselves arguments depicting the social construction of race comparatively in the U.S. versus Jamaica. And as these two chapters show, racial essentialism provided the basis for the evolution and crystallization of the one-drop rule in the U.S., but the rule itself is socially constructed.

The social construction of the one-drop rule is directly related to racist ideas about white racial superiority that evolved under the particular circumstances of slavery in the U.S. The next section thus explores the emergence of the rule within that context. 
Section 1 - Race and Mixed-Race during Slavery: The Social Construction of the One-

$$
\text { Drop Rule }
$$

\section{The Construction of "Race" During Slavery}

Although race in America began to crystallize under slavery, it is very important to understand that the motivation for slavery was not initially racial; in fact, the gradual reliance on African labor and the fact that this led to choosing skin color as the basis for social status is likely have been based largely on convenience (Franklin 2005, Gossett 1963, Smedley 2007). The first Africans were brought by colonizers to North America early in the seventeenth century as indentured servants to supplement the local labor supply (Franklin 1967). Attempts to depend on forced Indian labor had failed and colonizers who had employed European indentured servants had to contend with the need to replace servants at the end of their term (Franklin 1967).

The Africans who were first brought to Jamestown, Virginia early in the seventeenth century were initially conceived of and treated as indentured servants (Franklin 1967, Fredrickson 1971, Gossett 1963). Similar to white indentured servants, many were freed after a limited term of service had ended (Frederickson 1971). Africans were listed in the census counts of 1623 and 1624 as "servants" and, as late as the middle of that century, many were being assigned land at the end of their periods of indenture, similar to white servants (Franklin 1976). For most scholars, these facts were evidence that color held little or no significance in the early years of settlement - at least when it came to social organization of people in the bottom stratum of society.

The situation changed gradually and with varied degrees of intensity, as colonizers' need for labor became more pronounced and as they came to realize that 
Africans could be kept permanently - thus ensuring the much needed labor supply (Franklin 1967). In fact, during the early colonial years, Africans in areas outside of Virginia had been immediately assigned slave status by landowners (Daniel 2004). By 1650 black servants had generally ceased to be considered and treated as such; they had become slaves (Davidson 1971). In the ensuing centuries, the North American version of New World slavery developed, creating in its wake a new society and an economic system that relied heavily on African (black) labor for its perpetuation.

Several factors facilitated the boundary-work that whites performed in order to enslave their African servants. The most salient of these factors was their distinctive physical appearance (Franklin 1967, Smedley 2007). Planters quickly realized that unlike white servants, Africans could be easily distinguished because of their color and phenotype. Thus African runaway servants were more quickly detected than their white counterparts. In short, their color facilitated their subjugation to white control (Franklin 1967). Additionally, their non-Christian status permitted more severe punishment than that meted out to white (Christian) servants. Africans were also thought to be better suited than European servants to plantation labor, because, unlike Europeans, they were pre-acclimated to work in hot climates (Curtin 1971, Harris 1964). Africans were, moreover, easier to enslave because they were better prepared by the cultural traditions of slavery and serfdom that had been part of many sub-Saharan African societies prior to European contact (Harris 1964). Those traditions facilitated the institutionalization of the African slave trade and, in the process, planters' ability to replenish slave labor increased. Africans quickly came to be seen as an inexhaustible labor supply (Franklin 1967). 
European colonialism of the Americas and the ensuing labor shortages the colonists encountered generated a demand for more laborers and a more compliant labor force. They could not depend upon indentured servitude to solve this labor problem and they turned to slavery, but not just any slavery. Rather, they turned to slavery predicated upon a new idea-racial stratification. This new era of slavery, thus, is the crucible in which "race" is constructed. There are a number of reasons for this. First, and perhaps most important, race served as justification for the enslavement of Africans. A justification was necessary because the institution clashed with ideals about "liberty" "equality" and "fraternity" that were shared by all Americans (Franklin 2005, Myrdal 1944, Smedley 2007). These ideals were the bases upon which the War of Independence had been fought. They stemmed from the rhetoric of Enlightenment thinkers who held that all men were created equal. Yet the enslavement of one particular group of people implied that all men were not in fact equal (Myrdal 1944).

Gunnar Myrdal (1944) refers to the conflict between the Negro's subjugation beginning with slavery and the American ideals of equality and liberty as the "American Dilemma." The solution to that dilemma was to assert the "natural" inferiority of the Negro. To early Puritan settlers, the Negro was considered inferior primarily for religious reasons. As non-Christians, Negroes were labeled by the dominant Christian population as heathens and Barbarians. Giving them these labels crafted the justification of slavery as good for Negroes because it brought them into contact with Christian values, norms, and salvation (Franklin 1967). Moreover, this characterization implied that as Barbarians Negroes "needed" the humanizing and exposure to civilization that enslavement by Christians would provide. Over time the Christianization of the Negroes, one part of the 
overall social construction of race, came to be one of the primary justifications for their enslavement. Since enslavement of non-Christians was justifiable, it soon became conceivable to focus on the Negroes who were the only non-Christian group being used for labor at that time.

Various individuals sought to solve the dilemma posed by the conflict between their values and their involvement in the enslavement of Africans by appealing to these ideas. One example is President Thomas Jefferson, who opposed the institution and who frequently wrote that he looked forward to its termination. Yet Jefferson himself owned slaves. He solved the conflict between material concerns and personal ideals by affirming widely shared notions of the Negro's innate inferiority. He argued that because of Africans' natural "inferiority" they could not survive without the "protection" provided by the institution (Franklin 1967, Gossett 1963, Smedley 2007). Abolition should therefore be postponed for some distant and indeterminate time in the future.

Slavery also fostered the construction of race because of the very nature of the institution. That is, the institution created conditions that produced in slaves, behavior that suggested they were, in fact, inferior. Under the institution, landowners understood African slaves to be their property and treated them as such. Especially in the South, several states established severe Slave Codes that prohibited slaves' testimonies in court. By these codes slaves could not make contracts, own property, or leave plantations without prior approval. The codes inflicted strict punishment on slaves who did not abide by these regulations. Slaves were excluded from participation in the dominant culture and from benefiting from civil rights such as adult suffrage and education. These and other facts produced a people who were largely illiterate, lacking in initiative, and virtually 
helpless. Smedley (2007: 154) puts it this way, "When a people were treated like beasts, they inevitably behaved accordingly. The slavish, cringing behavior forced on the slaves, the stumbling and awkwardness, the inability to remember simple directions, the feigned ignorance or ill-health, all were postulated as innate. This belief was then used as justification for the further indignities and brutalities of slavery."

Whites used such behavior as evidence of the Negro's inferiority and proof that it was to his benefit to be in bondage (Davidson 1971). These patterns implanted in whites' minds the belief that behavior and biology (race) were inseparable (Smedley 2007). Because of his presumed innate inferiority, the Negro's natural lot, they argued, was enslavement by the superior white race (Davidson 1971, Franklin 1976, Elkins 1971).

Nevertheless, enslavement continued to produce deep conflict for many Americans, particularly in pre-Revolutionary years, as Americans looked forward to obtaining freedom from an oppressive colonial power. So profoundly was that conflict felt that the result was an intensification of arguments to justify the institution of slavery and the continued unequal treatment of the Negro based on race. Part of this justification rested on Christian mythology surrounding the story of the Biblical character, Noah's son Ham. According to the story, God becomes angry at Ham for looking at his father, Noah, while the latter was naked. God thus curses Ham, assigning him the role of his brother's servant, and condemning all his descendants. Though not actually found in the biblical record, Europeans later came to interpret the curse as God's rejection of black people. Alleyne (2002: 52) argues that this interpretation had far reaching effects as it later served as justification for the subjugation and exploitation of Africans. If the Negro is in fact 
cursed by God based on Ham's sin, then the Negro is not, in fact equal in God's sight (Alleyne 2002).

During the eighteenth century as Europe moved away from reliance on religion to an emphasis on science and reason, this religious explanation no longer served its role well. In order to continue to discriminate against people of African descent, believers in this social status needed to find scientific “proof” of the Negro's innate inferiority (Gossett 1963, Smedley 2007). Fortunately for them, European colonial expansion and the development of New World slavery coincided with the rise of science (Smedley 2007). Learned men responded to the growing need that people felt for classification of different groups of people. Beginning in 1735 with Swedish botanist Linneaus' classificatory scheme, several European scientists including Louis LeClerc and German professor of medicine, Johann Blumenbach, sought to classify and rank varieties of humans. Blumenbach proposed five classifications (Caucasian, Mongolian, Ethiopian, American and Malay) which became widely used by academics (Smedley 2007).

While there was much disagreement among these individuals regarding the number and nature of these varieties, their classifications had a significant impact on the evolution of race ideology. First, in establishing these classifications, scientists assigned an air of permanence and rigidity to ideas about human differences and rendered them easily available for transmission to others (Smedley 2007). This is exactly the argument that David Theo Goldberg (1997) makes. Writing about census categories, he asserts that in "naming or refusing to name, existence is recognized or refused, meaning and value are assigned or ignored, people and things are elevated or rendered invisible. Once defined, symbolic order has to be maintained, serviced, extended, operationalized" 
(Goldberg 1997: 29). The naming of these categories, clearly a type of boundary-work by individuals with more power than those who were being bounded by racial labels, served to confirm already existing ideas that linked physical characteristics with behavior. The categories, moreover, fostered the establishment of hierarchies and inequalities among the groups being identified. Last, the fact that they had been crafted by such well-known and reputable scientists helped to justify the subjugation of non-Europeans by legitimizing as "natural" inferior qualities ascribed to them by Europeans (Smedley 2007).

In short, the classifications provided by these $18^{\text {th }}$ century scientists supported and confirmed notions about the Negro's innate inferiority. The classifications and accompanying ideas spread from the academic world and became popularized in all sectors of American society. Prominent intellectuals such as Voltaire and Thomas Jefferson publicly expressed their conviction that the Negro was a separate species, different from and inferior to Europeans (Gossett 1963, Omi and Winant 1994, Smedley 2007). Such distinctiveness was used to justify the unequal distribution of political and social rights while at the same time maintaining the ideal of equality among men (Omi and Winant 1994).

Thus far I have argued that race was constructed as a result of the specific circumstances of slavery. To secure their privileged position, slave owners required the creation of two separate and distinguishable groups: the enslaved, and the free. Once planters in the U.S. discovered that African slaves, by virtue of their dark skin color, could be more easily kept in subjugation and guarantee a labor supply, they used skin color as the primary means of distinctiveness. And since slavery conflicted with the 
widely held ideal that all mean are equal, white colonizers crafted notions about Negroes' innate inferiority and supported by scientific "proof," used those notions to ensure their subordinate position in the social hierarchy. These notions justified not only the institution of slavery but also the severe codes that the planting class established to regulate the plantation system and keep slaves in subjugation. Their actions were the beginning of what Douglas Massey (2007) has termed "categorical inequality," the result of a process by which humans assign individuals to social categories and then institutionalize practices that ensure that resources are allocated unequally across those categories.

Planters aimed to ensure the maintenance of racial purity. But their efforts were unsuccessful, largely as a result of extensive miscegenation. Race mixing, in fact, presented real problems for the status quo as it blurred the boundary that was being carefully constructed between blacks and whites in that period. The next section discusses the impact of miscegenation during slavery on racial boundaries, and describes whites' efforts, through boundary-work, to combat the threat it presented to the statusquo.

\section{Miscegenation and the Emergence of the One-Drop Rule}

To this point, the social construction of race in the United States grew from the seed of labor shortages and was fertilized multiple times by slave owners' and other whites' ideologies drawn from the Bible and science. These certainly promoted both rapid and widespread growth of race as an important force in social stratification; but it was still not institutionalized. Institutionalization was the next major step in the 
construction and fortification of race. This institutionalization came in the form of the one-drop rule, though the rule took time to take root.

The one-drop rule in the United States arose out of the alchemy of white racial superiority and fears of slave insurrection especially as the slave population grew. Interracial relationships between white settlers and Native Americans and Africans had begun to occur during the earliest periods of European settlement of the colonies, especially as white landowners did not hesitate to take advantage of their female indentured servants (Davis 1991, Frazier 1967, Reuter 1969, Spickard1989, Williamson1995). Although there was evidence of disapproval of such liaisons, in the beginning such mixing was met with relative tolerance on the part of the wider society (Davis 1991, Gossett 1997). There were initially no laws preventing or punishing race mixing or intermarriage. And the one-drop rule would not appear until later (Davis 1991).

Whites' relative leniency toward interracial liaisons that witnessed early colonial periods rapidly transitioned into active boundary work against miscegenation (Williamson 1995). While the African slave population had been small enough during the seventeenth century to allow for the demographically as well as socially superior white authorities to deal with such mixtures on an ad hoc basis, rapid growth in the slave population during the following century prompted anti-miscegenation legislation (Spickard 1989). As the slave population increased, white fear of slave insurrection grew. Therefore whites passed a number of laws to solidify the boundary between slaves and whites, and punished those (both black and white) who crossed the boundary by engaging in such unions (Spickard 1989). In time race-mixing became the single most-contested feature of race-relations. The fact is that race mixing was problematic since it implied the 
crossing of racial boundaries that in the minds of whites were impermeable. As such, miscegenation challenged widely held notions about the fixed nature of race, and racial purity. Most importantly, miscegenation thwarted whites' desire to maintain white racial purity. Thus the prohibition on race-mixing in time became the "main pillar of the American racial structure" (Spickard 1989:238).

Despite growing opposition and increasing punishment, miscegenation continued to occur on large scale. In fact, interracial sexual contact was frequent and widespread during the 250 years of slavery (Blassingame 1972, Davis 1991, Frazier 1966, Myrdal 1944, Rockquemore and Brunsma 2008, Spickard 1989, Williamson 1995). While some of this miscegenation consisted in white men pursuing lasting relationships - taking slave women as their concubines and not just fly-by-night sexual encounters--and while a relatively few such liaisons occurred between white women and black slave men, most of such contact consisted in exploitation by white males of their privileged position in society. They used this privilege to extract sexual favors from Negro women and young girls by force (slave and free) (Blassingame 1972, Franklin 1967, Frazier 1966, Spickard 1989). Negroes sometimes resisted but such resistance was often met with severe punishment. Thus, their low social status as slaves made slave women vulnerable to their white masters' advances.

The result of extensive miscegenation was the appearance of a rapidly growing mixed or "mulatto" population. Franklin (1967) reports that by the time of the first count of mulattos in the census of 1850 there were 246,000 mulatto slaves -7.6 percent of the total slave population of $3,200,000$. By 1860 this number had increased to $411,000,10$ percent of 3,900,000 slaves (Franklin 1967). Since most mulattoes were assigned the 
status of their slave mothers and enslaved as well, the implication of the growing number of mulattoes was a lightening of the slave population.

The growth of the mixed race population, albeit largely a population still enslaved, heightened whites' concerns over their ability to maintain racial purity. Whites therefore took steps, through boundary-work, to rectify the situation. Their efforts to reduce the unease caused by mulattoes were, however, gradual. Thus, at first the status of mixed offspring was uneven - varying by region. Williamson (1995) identifies two "Souths" in describing the status of mulattoes. The first is the upper South (consisting of North Carolina northward and westward as far as Pennsylvania) where mulattoes appeared early in the colonial period and where they were often the product of unions between blacks and members of the white underclass. There, the mulatto population grew rapidly and increased their number over generations, he explains, largely by establishing relationships among themselves. Since these mulattoes were mainly poor rural folk, Williamson argues, they were largely viewed as black by the white elite.

In the lower South (South Carolina south and westward toward the Gulf of Mexico) the mulatto population appeared late and grew more slowly. They were born primarily to wealthy white males, many of whom recognized and supported their mixed offspring. Thus, in contrast mulattoes in the upper South, they were considered valuable by the white elite. This was especially so in Charleston (South Carolina) and lower Louisiana where mulattoes were most numerous, affluent, and - because of constant contact with the white elite - "cultured." Rather than simply being relegated the position of slaves and, as such, identities as black, mulattoes in the lower South were therefore 
permitted the status of an intermediate group between the dominant white and subordinate black groups.

The relatively lenient response to mulattoes in the lower South was in part influenced by the importation of West Indian traditions (Davis 1991). Many of the area's first slaves and white settlers came from Barbados, where it had long been the practice for mulattoes to hold a status that is higher than that of unmixed blacks. Also influential was the legacy of French Catholicism and the large numbers of immigrants from Santo Domingo and Haiti who arrived in eastern Carolina and lower Louisiana during the first years of colonization. Wealthy mulattoes there became a dominant social group (Davis 1991, Williamson 1995). It is likely that their wealth, relative to mulattoes in the lower South, combined with their comparatively small numbers made them more acceptable as a buffer group. On the other hand, upper South mulattoes' low social status and large numbers likely rendered them undesirable and confirmed rising convictions that mulattoes, as half-breeds with black "blood," were inferior.

In other areas (such as Virginia and Maryland) the offspring of mixed unions initially held uncertain legal status. Such uncertainty was, however, gradually replaced by laws designed to relegate mulattoes to an inferior position. The first such law was passed in 1662 in Virginia. Under this law, mulatto children born to slave mothers were to become slaves (Williamson 1995). Very soon similar legislation was passed in other regions of the South. And by the middle of the middle of the $19^{\text {th }}$ century much of the nation had come to apply the rule known as "one-drop" or "hypodescent" by which the criterion used to identify mixed race offspring was any traceable amount of Negro “blood" (Davis 1991, Williamson 1995). 
The one-drop rule emerged during slavery but it did not take its most solid form until after emancipation. During the entire slave period, there were various "rules" for racial identification of racially mixed people (Davis 1991). While the one-drop rule was generally that which prevailed on black belt plantations ${ }^{4}$ the "rule" continued to be rejected in South Carolina until the 1850s (Davis 1991). Similarly the influence of French and Haitian conceptualizations of race mixing in Louisiana resulted in mulattoes being eventually being identified as "Creoles" (Davis 1991, Dominguez 1993). The "one-drop" rule did not become institutionalized outside of the slave states and across the entire nation until the 1920s - six decades after emancipation (Davis 1991).

As the modern idea of race crystallized under slavery, white Americans become increasingly concerned with maintaining racial purity, with particular emphasis on the prevention of interracial sexual contact. Their efforts at racial boundary-work reflected the emerging race ideology based on the presumption of white racial superiority. Therefore, as the mulatto population increased, white Americans, especially in the lower South, became increasingly concerned with determining who was white. Race had been constructed during slavery to establish a social hierarchy that favored whites. The appearance of mulattoes threatened that order. Their liminal state could not be endured in a social system that thrived on a rigid dichotomy. To deal with them, the one-drop rule was created. Since the rule simply assigned black identity to individuals with any trace of black "blood" in whites' minds it re-drew the line that separated whites from blacks. Their efforts at maintaining racial borders were thus reflected not only in legislation

\footnotetext{
${ }^{4}$ Geographically, the "Black Belt" included Alabama from eastern, south-central Alabama into northwestern Mississippi. Though referring to the rich, very fertile dark soil that characterized the region, "Black Belt" meant the region with the largest number of slaves. http://www.southernspaces.org/contents/2004/tullos/4a.htm
} 
prohibiting and punishing miscegenation, but also in the emergence and spread of the one-drop rule. The next section will show that as race ideology became even more firmly rooted in American society, albeit counter-intuitively, in response to the abolition movement, emancipation, and the Southern loss of the Civil War, racial boundary-work intensified and culminated in de jure segregation as well as the crystallization of the onedrop rule.

Section 2 - The Rise and Crystallization of Bright Boundaries

From roughly the antebellum period through the early $20^{\text {th }}$ century blacks and their supporters made several efforts to dismantle boundaries drawn by race. Those efforts threatened to blur the boundary between whites and blacks, and thereby whites' social status. And whites responded to each threat with boundary-work geared toward reconstituting the boundary between blacks and whites.

The black-white boundary that was constructed during slavery, though linking skin color with slave status, was about much more than just physical appearance. It encompassed all the various ways, discussed in the previous section, that blacks had been characterized in opposition to whites: feeble-minded/intelligent, not-fully-human/human, Heathens/Christians, black/white, slave/free. This cluster of characterizations was important for the maintenance of the black-white boundary. Each implied that blacks were essentially different from whites in ways that were damaging. As inferior, not-quitehuman, unintelligent, descendants of Ham, enslavement by superior whites was viewed 
as their "natural" fate. Slavery, then, was not an evil institution but, rather, the "humane" mechanism that kept Negroes safely in their rightful place.

Contesting Racial Boundaries: Abolitionists, Free Negroes and Slaves Oppose Slavery Among the threats posed to whites' social status were those mounted against the institution of slavery by abolitionists, free Negroes and slave revolts. The abolition movement began to launch direct attacks against the institution of slavery in the eighteenth century thereby challenging the boundaries it had erected and preserved (Franklin 1969, Quarles 1971). For reasons that were both economic (the Northern industrialized economy did not rely on slave labor) and ideological, most of the abolition agitation came from Northern states. Humanitarian sentiment that was influenced in part by Enlightenment ideals about human rights and also by America's own struggle for independence from England placed additional pressure on the institution of slavery. Americans became increasingly uncomfortable with the fact that while they were demanding freedom from the mother country they were themselves holding human beings in bondage (Franklin 2005, Gossett 1963, Smedley 2007).

Abolitionism thus grew on the basis that it was wrong for one group of human beings to treat another as property. Religious opponents of slavery such as the Quakers and Methodists argued that the institution stood in violation of all Christian principles about how others ought to be treated, about the equality of all men, and where they were able to successfully Christianize slaves, fellow Christians. Critics also argued that the institution countered the basic principles of America which valued freedom as a basic 
human right and that slavery was having a harmful moral impact on the dominant class (Franklin 1967).

At the same time, slaves were also making efforts to dismantle boundaries through many forms of resistance. Many slaves sought freedom by running away sometimes hiding in hilly areas close to plantations, sometimes forming or joining Maroon communities (Blassingame 1972, Franklin 1967). Aptheker (1971) reported that tens of thousands fled successfully from plantations. Other forms of resistance included malingering, sabotage of master property, setting fires to outhouses, barns and at times the manor house and slowly poisoning members of the master's family. Additionally, it was not uncommon to hear of slaves attacking overseers or masters with "clubs and knives and bare hands" (Aptheker 1971).

Slave resistance and rebellion and masters' inability to prevent their escape threatened the white elite. In addition to inciting terror among the members of the white elite, slave rebels "'curdled' the blood of many Southern whites...Symbolic of black resistance to slavery, the rebel and the runaway indicate quite clearly that the black slave was often ungovernable" (Blassingame 1972: 221). Their persistent resistance evidenced a deep desire for freedom; but it also refuted white propaganda about the Negro's docility and his contentment as a slave (Aptheker 1971, Franklin 1967). The many slave revolts in the islands and other parts of the New World only increased whites' fears. In particular, the success of the Haitian Revolution in 1804 and the subsequent ousting of the French by Negro leaders produced great terror among North American slave owners (Franklin 1967). In the wake of that Revolution, some Southern states restricted the importation of Africans. 
Yet another cause of concern for the white planter class was the growing free Negro population, which by its very existence transgressed the boundaries between the enslaved and the free (Franklin 1967). Free Negroes had been present in the colonies since the early colonial period (Williamson 1995). However, the number had been increasing due to the prohibition of slavery in several Northern states, as well as frequent manumissions prompted by egalitarian ideas of the Revolution. Other slaves found ways of accumulating sufficient funds to purchase their freedom. Children born to freed slaves added to their number. While in 179059,000 free Negroes were counted by the first decennial census, by 1830 the number had increased to 319,000 (Franklin 1967).

For planters in the South the presence of free Negroes was "a source of constant embarrassment" (Franklin 1967:214). They perceived free Negroes as a threat to the entire social system of the South which relied on and was organized around the existing relationship in which whites were dominant, and blacks subordinate to and completely dependent on the white population (Franklin 1967). Freed slaves' very existence challenged assertions about the Negro's "need" for enslavement and the protection of their masters, and in so doing challenged the boundaries that ensured continued separation from and domination by whites. Therefore increasingly every attempt was made to impede social and economic advancement.

Privileged whites grew more and more nervous about their social standing as a number of free Negroes, determined to break through those boundaries, were in fact actively involved in the anti-slavery movement from the beginning (Bethuel 1997, Franklin 1967, Quarles 1971). Free Negroes' goals were twofold: to obtain freedom for blacks who were still enslaved; and to uplift the free black population (Quarles 1971). 
Free Negroes were thus actively involved in antislavery societies (such as American Anti-Slavery Society formed in 1833) and also formed over twelve black societies by 1837 (Quarles 1971). Through their involvement in these societies, National Conventions denouncing the institution, the Underground Railroad that assisted runaway slaves and numerous publications, free Negroes contested the color line and challenged the status of whites.

In sum, white boundary-making in the U.S. was challenged very early during the era of slavery. Opposition came not only from white members of the anti-abolition movement, but also from blacks, both slave and free, who through various means of resistance, battled not only the institution itself, but also ideologies of Negro innate inferiority. The efforts of white and black abolitionists to defeat slavery intensified during the early-to-mid- $19^{\text {th }}$ century inciting panic among dominant whites. Finally, when the South lost the Civil War and slavery was abolished in 1865, whites' fears of losing their social status led to an escalation of racial and racist rhetoric and politics.

\section{White Response: Entrenchment of Racist Ideology}

Scholars (Franklin 2005, Fredrickson 1971, Gossett 1967, Smedley 2007) agree that challenges to the bright borders under slavery by slaves themselves as well as by white abolitionists actually provoked an entrenchment in racist ideology. In response to onslaughts against the institution and the consequent fears of losing their privileged status to the class of people they most despised, proslavery Southerners mounted an intense defense that was entirely based on the presumed innate inferiority of the Negro. While in the North abolitionists' activities provoked an ameliorative response and individual 
manumissions, in the South it simultaneously provoked a hardening of racist attitudes (Smedley 2007). Thus, citing Donald Noel who wrote that racism "emerged from the 'necessity' to defend a profitable institution which was under attack," Smedley (2007: 209) asserts that had it not been for the opposition to slavery, there might never have existed the need to develop such racist ideology. Fredrickson (1971: 253) agrees, writing that, "Explicit racism, a public ideology based on the doctrinaire conception of the black man as a natural underling, developed...directly out of the need to defend slavery against nineteenth-century humanitarianism." Fredrickson argues "societal racism" - that is, social practices that hold blacks in subjugation thus treating them as if they are inferior had long existed in the U.S. No firmly entrenched race ideology was needed to support discriminatory social practices generated by whites under slavery, Fredrick notes, until they were challenged by the abolition movement. Since abolitionists were appealing to the egalitarian ideals that had become prevalent during the revolutionary era, proslavery advocates had two choices: reject the idea of equality entirely or find that blacks are an entirely "different order of beings from whites" (Fredrickson 1971: 251). The latter argument was chosen partly because of the belief that it would appeal to nonslaveholding white Southerners and perhaps to some Northerners. It was chosen, more importantly, to strengthen the border that divided whites from blacks.

The pro-slavery defense riding on the Negro's inferiority took many forms. In Southern states the white elite utilized publications such as William Drayton's 1836 pamphlet entitled The South Vindicated from the Treason and Fanaticism of the Northern Abolitionists. He wrote that the Negro was “... indolent and prone to vice; that his mind is heavy, dull, and unambitious; and that the doom that has made the African in all ages 
and countries, a slave - is the natural consequence of the inferiority of his character" (Fredrickson 1971: 252). Defenders of the institution also increasingly praised the virtues of the paternalistic nature of plantation life in Southern states (Myrdal 1944, Smedley 2007, Stamp 1971). Popular ideology held due to the innate inferiority of Africans, enslavement was their natural status (Smedley 2007, Myrdal 1944). Slaves therefore "needed" their masters and were thus content with their status. ${ }^{5}$

Another tactic reinforcing existing beliefs in Negroes' inferiority and their need to be cared for under the white-dominated institution of slavery was the popularization by antebellum novelists, journalists and dramatists of the "Sambo" image (Blassingame1972, Stampp 1971). Sambo was the most frequently used of three major slave characters that repeatedly appeared in novels and plays in the antebellum years. The others characters (Jack and Nat), while less demure than Sambo, nonetheless were portrayed as deferential in the presence of their masters. Furthermore, both were portrayed as hiding strong feelings of resentment against their masters, feelings that stoked the fears of whites. Sambo, however, was whites' ideal Negro. Not concerned with attaining his freedom, he was "indolent, faithful, humorous, loyal, dishonest, superstitious, improvident, and musical... inevitably a clown and congenitally docile" (Stampp 1971). He was also depicted as having great affection and respect for his master. The popularization of Sambo was useful to Southern whites for two primary reasons.

\footnotetext{
${ }^{5}$ There was some evidence of paternal and amicable, even warm, relationships between specific slaves and masters. These types of relationships, however, usually existed only on plantations that were small enough to afford close contact between the slave and his master, and were mostly concentrated in relationships between household slaves and masters (Stampp 1971). Furthermore cases of authentic paternalistic relationships resulted in a "process of infantilization" which planters used "to prove that Negroes were a childlike race, needing guidance and protection but inviting paternal love as well" Stampp (1971:119).
} 
First, the image reflected the perceptions long held by whites that blacks were "ignoble savages who were innately barbaric, imitative, passive, cheerful, childish, lazy, cowardly, superstitious, polygamous, submissive, immoral, and stupid" (Blassingame 1971:227). Second, the idea of "Sambo" was comforting to whites particularly in the face of growing fears of slave rebellion. The Sambo image was so pervasive and so in line with whites' desires for Negroes that people, including many historians, came to accept it with no little or no research at all - as an accurate depiction of the Negro (Blassingame 1972).

Thus to counter anti-slavery arguments, whites increased their reliance on the ideology of black inferiority to defend the institution. And in seeing to the entrenchment of racist ideology based on Negro inferiority and in depicting blacks as an entirely different order of being, indeed, as not even quite human, whites effectively strengthened the color line. These acts of boundary-work began, however, before the Civil War. More extreme measures of boundary-work were established when the South lost the Civil War and along with it, the institution of slavery.

\section{Emancipation and Reconstruction Blur Boundaries}

The Northern push to abolish slavery provoked the ire of white Southerners whose social system relied on the use of Negro slave labor. The Southern economy, still primarily agrarian, lagged behind Northern states in terms of industrialization. Whites in the South therefore conceived of slavery as central to the survival of the South. Moreover, emancipating the slaves threatened to blur the carefully constructed color line that had been erected under slavery and that had carved out a status quo that favored whites. In the minds of Southern whites, emancipation would not only spell economic 
disaster for them, but would also dismantle the old and treasured social order. As pressure mounted from the North, several Southern states threatened secession from the Union, and many eventually seceded. Southerners mounted staunch resistance when, in 1861, the newly elected President, Abraham Lincoln, began to take steps toward emancipation. Civil War erupted as a result of mounting tensions; and the Southern loss of the War combined with the end of slavery incited Southern whites to unite around race in order to preserve their status (Franklin 1967).

The years following the Civil War and the Reconstruction era were also turbulent for the country, but especially so for the South. Southern states experienced great economic devastation after the War. The defeat of slavery threw the plantation system into upheaval as freed slaves left plantations, refusing to work for their old masters. As part of Reconstruction, the federal government established various federal agencies such as the Freedmen's Bureau to help former slaves with their transition into freedom (Franklin 1967). Funding was provided to assist ex-slaves acquire and cultivate land, and become educated. Radical Reconstruction in 1867 provided for black political enfranchisement (Franklin 1967, Nobles 2002). Largely due to staunch opposition from Southern whites, and to gradual withdrawal of support from the North, Reconstruction failed to provide blacks the full freedom opponents to slavery had wanted. Nevertheless, for whites, already demoralized by their loss of the Civil War, these provisions only added insult to injury (Davis 1991, Franklin 1967). 


\section{Southern Whites Defend their Status, Strengthening Racial Divides}

\section{Jim Crow: Legal and Extra Legal Patrolling of Racial Boundaries}

Their loss of the Civil War and the defeat of slavery in 1865 prompted Southern whites to search for new ways to recreate the old social system and reconstitute the boundary between them and blacks. In response to the provisions of the 1867 Reconstruction Act which disenfranchised large numbers of Southern whites, they launched a program of Restoration - to restore white rule. States passed a series of Black Codes which were so restrictive they were barely distinguishable from the abolished Slave Codes (Franklin 1976). Whites also formed secret societies that terrorized both blacks and whites representing the federal government.

Southern whites had one goal in mind: to restore white rule. And they sought to do so through Jim Crow - a carefully patrolled system of legal segregation that was officially based on the doctrine of "separate but equal." Designed to ensure complete separation of the races, Jim Crow entailed segregation in public and private spheres including: public parks, beaches, public transportation, hotels, restaurants, schools and colleges, and housing (Myrdal 1944, Nagel 2003). It came with laws banning intermarriage and punishing all forms of race mixing and the removal of voting rights (Davis 1991, Myrdal 1944).

Named for the mythical figure which served as precursor to the "Sambo" image in literature, Jim Crow symbolized whites' derogatory view of blacks as "childlike, irresponsible, inefficient, lazy" (Davis 1991: 51). During this era these derogatory notions were magnified through the addition of Zip Coon, a character that appeared in minstrel shows and that represented blacks as lazy, stupid and criminal. Through the 
Coon character infantilization of blacks evolved into active demonization. Images of blacks as dirty, foul-smelling, and violent were distributed via newspapers, magazines, various mass media. In this way whites intensified the ideology that blacks were a different order of being.

The above strategies are examples of the ways in which boundary-work is often buttressed by "moral panics" that have in various societies classified certain groups or classes whose behavior or lifestyle has been deemed offensive, as "folk devils" (Sibley 1995). Already through Sambo, Nat, and Jack blacks had been depicted as infantile, stupid, willful, and rebellious. The addition of Zip Coon served to magnify these negative and transformed blacks into "folk devils" that needed to be kept separate from and subject to whites. Their transformation into folk devils is similar to the experience of an English Christian sect, the Ranters, whose members were demonized by English society in the early modern period because their beliefs dissented from mainstream church doctrines (Sibley 1995). Demonization occurred in the form of stories that were spread verbally and in writing that linked the sect with atheism and immorality. Despite limited freedom to engage in sexual contact outside of marriage, Ranter women were portrayed as being sexually liberal. Although there was little truth to the stories that were popularized about members, the stories effectively demonized members, especially women, in the eyes of the wider Christian world.

When a group is demonized as blacks and Ranters were, the truth becomes irrelevant. Images, rumors, stories that are disseminated and widely accepted become "truth" to members of the society. Their transformation into folk devils reflects society's need to "define the contours of normality and to eliminate the difference" (Sibley 1995: 
40). As folk devils, then, they are not just different, but also abnormal and dangerous. And as such, they must be kept separate. Jim Crow provided just the means to do so.

The "separate but equal" doctrine that was central to Jim Crow was established by the U.S. Supreme Court in the 1896 case Plessy v. Ferguson which ruled in favor of segregated seating on trains providing that the accommodations were equal (Davis 1991). The Jim Crow system, which prevailed primarily in the South, was, however, anything but equal; rather, it both ensured and relied upon extreme forms of discrimination against blacks (Davis1991, Myrdal 1944, Williamson 1995). In reality, “separate but equal” was in legal fiction, designed to deal with the conflict between existing racial inequality and American ideals (Myrdal 1944). Through Jim Crow whites aimed to keep blacks "in their place." Since blacks had been deemed inferior, abnormal, and dangerous, that place had to be vastly inferior (Davis 1991, Myrdal 1944).

Southern whites who did not belong to the planter class were staunch supporters of Jim Crow because they feared that freed slaves would make their own status even more precarious (Davis 1991, Myrdal 1944). Largely responsible for extralegal enforcement of Jim Crow as well as the formation of the Ku Klux Klan (Myrdal 1944), these poor whites knew that they had to hold the line on Negroes' social advancement. They realized that the common denominator they could share with the landowners, the elite, was race. To bind themselves to the white elite, however, they had to create boundaries to blacks' advancement as powerful as those which kept Negroes circumscribed under slavery. They had to emphasize whites' difference and superiority over blacks - the classic formula of categorical inequality (Massey 2007). Jim Crow laws constructed around privileges accorded by race were the perfect solution. The laws 
homogenized internal differences within race groups — such as socioeconomic class - and streamlined status into two social classes that were based entirely on color. The one-drop rule would become pivotal at this point because it provided a bright boundary for distinguishing "white" from "Negro" and for according the lower, Negro status to those of mixed race (Davis 1991).

Viewed as a principal means of ensuring racial separation, the prevention of race mixing was at the heart of Jim Crow. It was the central concern of whites and at the root of their obsession with maintaining racial purity. Race mixing had long been viewed as a major threat to the color line. While sexual unions (excluding marriage) between white men and black women occurred frequently and were often overlooked, mixing between white women and black men was especially abhorred (Davis 1991, Myrdal 1944, Smedley 2007, Williamson 1995). In fact, guarding "white womanhood" was the "hallmark of the Jim Crow system” Davis (1991: 62). During Jim Crow long-held ideas portraying black males as highly sexual and desiring white women were widely disseminated and used to justify intense border patrolling that characterized the period.

Jim Crow intensified white border patrolling to prevent race mixing. White concerns about miscegenation resulted in the rapid passage of anti-miscegenation laws in Southern states after Reconstruction. Sixteen of the seventeen states that had part of the slave South in 1861 passed laws prohibiting mixed unions and the one state that refrained from doing so (West Virginia) made provisions to punish white persons who engaged in such unions (Williamson 1995). Increasingly, more states outlawed miscegenation to one degree or another. So central was anti-amalgamation sentiment to the Jim Crow system that its proponents became obsessed with barring race mixing not only by law but also 
through extra-legal measures (Davis 1991, Myrdal 1944). In the early years of Jim Crow the most feared extra-legal punishment for race mixing was lynching. According to figures kept by the Tuskegee Institute 1,111 blacks were lynched during the last decade of the nineteenth century (Davis 1991). And among the most common reasons given for lynching were rape or attempted rape of a white woman (Davis 1991, Norrell 2005).

\section{Crystallization of the Bright Boundary: the One-Drop Rule}

The most significant outcome of this turbulent era was the solidifying of the onedrop rule. While it had emerged during slavery, the rule actually crystallized during the period the changeover in race relations between 1850 and 1915 during which time white semi-acceptance of mulattoes was gradually replaced by outright rejection (Williamson 1995). The rule crystallized as a result of rising fears among members of Southern whites about abolitionism, insurrection and the loss of privilege. To deal with such fears, whites searched for an order that would locate groups in specific and determinate social locations. That order was based on the erection of dichotomies (black and white, slave and free). There was no place for mulattoes in that dichotomy. As a result white agitation against free mulattoes gradually intensified and increasingly mulattoes were enslaved. In essence this new order created two classes - slave and free, and as there was no room for a middle category, relegated mulattoes to slave status (Williamson 1995).

Thus the process of crystallization the one-drop rule began in the $1850 \mathrm{~s}$ in the latter years of slavery. As states continued to outlaw interracial unions it became even more necessary to determine just who was black (Davis 1991, Williamson 1995). Additionally, while until Reconstruction Southern white planters had often shown 
preferential treatment to slaves with lighter complexions, they increasingly joined with poor whites in the enforcement of Jim Crow. That is, race trumped old class divisions. Not surprisingly, mulattoes, frustrated by their loss of status, began to identify with the black population (Davis 1991, Williamson 1995). This unification strengthened their determination to draw brighter boundaries where blurred boundaries existed: between "pure" whites and people with degrees of African ancestry. Setting specific genetic boundaries became the province of different states: Seven states assigned Negro identity to persons with any Negro ancestry; seven (including Maryland, Florida, South Carolina) declared that anyone with one-eighth such ancestry was a Negro; and others such as Virginia used much smaller fractions - so that often Negro ancestry was difficult to discern by sight (Williamson 1995). In codifying race this way, it became deceptively more and more biological obfuscating race's socially constructed nature. Legal designations were, however, not the main determinant of racial identification of mixed persons. As far as most Americans were concerned, the one-drop rule prevailed regardless of legal definitions (Williamson 1995).

It is important to note that the one-drop rule was at no time completely uncontested (Davis 1991, Dominguez 1993). Creole elites in South Carolina and Louisiana resisted and continue to resist the rule by referring to themselves as "colored" (Davis 1991, Dominguez 1986). Dominguez (1993) notes that among Louisiana Creoles there continues to be a value hierarchy that is ordered by physical appearance and by which "whiter" leads to better status. Similarly, white Hispanic Americans and multiracial persons with Native American ancestry have steadfastly avoided black racial identity wherever and whenever possible (Davis 1991). Moreover Davis (1991) notes that 
in states such as New York, Maryland, West Virginia, Mississippi, several small isolated communities of racially mixed individuals who avoid the one-drop rule continue to exist. Such cases of resistance, however, have been the exception rather than the rule. In spite of such resistance, the one-drop rule has generally prevailed.

During Jim Crow, whites' efforts to police the border drawn by the one-drop rule intensified. In part, this intensification was the result of an ironic outcome of the one-drop rule: the passage of laws designating Negro identity to individuals with Negro ancestry, regardless of phenotype, had created new fears among whites of "invisible blackness." Since physical appearance no longer determined racial categorization, increasingly individuals who looked white were being classified as Negroes. More than two centuries of miscegenation had, however, made it virtually impossible for whites to be certain they had absolutely no Negro ancestry (Davis 1991, Williamson 1995). In fact, many mulattoes had no idea of their mulatto status.

The white appearance of many mulattoes permitted the phenomenon of "passing as white" by which racially mixed individuals crossed the color line and lived their lives as whites. The choice to "pass" was difficult as doing so often meant completely cutting ties with black family members. The fear that their black ancestry might be discovered made the experience not just nerve-wracking but also dangerous. Yet passing provided opportunities for individual mulattoes to escape the repressive conditions that were increasingly being enforced. Thus passing peaked between 1880 and 1925, a particularly repressive period of the Jim Crow era (Davis 1991).

Whites, paranoid about invisible blackness, therefore conducted a great deal of boundary-work to prevent accidental marriage to a Negro. Their fear of invisible 
blackness reached a fever pitch during the years of Jim Crow. During those years whites became so fearful that they insisted on attitudes of "closed ranks" among whites (Williamson 1995: 107). Border patrolling of marriages intensified. The heritage of intended spouses was subjected to intense scrutiny to ensure there was not a trace of Negro ancestry-a practice that continued well into the $20^{\text {th }}$ century (Williamson 1995). Even casual contact between whites and blacks was monitored. The term "white nigger" was applied to whites who collaborated with blacks to any degree at all (Williamson 1995).

Mulattoes, Blacks, and Boundary-Work

The impact of white withdrawal of support for mulattoes during and after Reconstruction had important implications for the one-drop rule and should not be overlooked. As mulattoes, frustrated by their loss of status began to align themselves with the black community, an era of cultural fusion of black and mulatto worlds began (Williamson 1995). Identification as black became an important rallying point as mulattoes and blacks united in their struggle against discrimination. Blacks, aware that the relative sophistication that many mulattoes possessed would be useful to their struggle, were willing participants in this new alliance. Soon mixed race individuals would become prominent and influential leaders in the black community. Mulattoes such as author Langston Hughes, W.E. B. Dubois, and NAACP leader Walter White who appeared to be white, were all leaders in the Harlem Renaissance in the early $20^{\text {th }}$ century (Davis 1991, Williamson 1995). Mulattoes were among the black men and women who took the lead in pre-civil rights and civil rights activism (Davis 1991, Norrell 2004). Thus 
despite some mulatto resistance especially among Creole elites in South Carolina and Louisiana, mulattoes have largely accepted the one-drop rule.

The cultural fusion of black and mulatto worlds into one "black" world has implications for the boundary-work that has maintained the one-drop rule. I have argued thus far that the one-drop rule was constructed through boundary-work on the part of white Americans to preserve their social status. Yet black and mulatto support for the rule has also contributed to its persistence. Blacks have joined in border patrolling, opposing intermarriage, and criticizing any appearance of weak allegiance to their community (Davis 1991). Black border patrolling, as section three will show, was to continue well into the $20^{\text {th }}$ century, in fact until contemporary times.

\section{Science Supports the One-Drop Rule}

Scientists also came to play an increasingly important role in policing the boundaries between black and white and in opposing miscegenation. They affirmed the existence of important genetic differences between the "races." They argued that racemixing produced a breed that was so inferior to that of its progenitors that it could not reproduce beyond the second generation and would thus soon cease to exist. In general, such ideas were based on a polygenist theory of origins. Led by Dr. Samuel Morton, American polygenists argued for the separate origin of the Negro. Morton believed that hybrids provided proof that Negroes were a separate species. From studies he had conducted among mulattoes he argued that mulatto women procreated only with great difficulty (Gossett 1963). Procreation with other mulattoes would lead to eventual extinction. The "fact" that there was thus, in the long term, no future for mulattoes led 
Morton to conclude that Negroes were not simply a variety of humans, but rather an entirely different species. In essence, they treated white-black offspring as analogous to the mating of a horse with a donkey resulting in the sterile mule. The invocation of genetics-based reasons for separating the races created a new ideology to legitimate race, much as Linnaeus' race typology and the story of Noah and Ham had done in the past.

The U.S. Census Bureau has also played a significant role in racial boundarywork. Though the census taking has in a sense responded to the needs of the state, it has also affected how race is conceptualized as well as how race serves to organize American political and social life. Census bureaus, argues Nobles (2002:43), “...are neither disinterested registers nor innocent bystanders. Rather, they are active, if overlooked, participants in racial politics.” In so doing, the census has supported white American boundary-work.

Census involvement in socially constructing race in the U.S. dates back to the first census in 1790; however, the "mulatto" category was not added until 1850. The addition of the mulatto category signaled a convergence of scientific thought about race and statistics in shaping public discourse about slavery. The category was created for the 1850 census specifically to facilitate scientific inquiry into the nature of mixed individuals. It was part of scientists' quest to prove the innate inferiority of blacks (Anderson 2001, Nobles 2000). In 1847 polygenist Josiah Nott who was one of the principal proponents of counting mulattoes as a separate race category in the census, justified it by saying, "If the blacks are intellectually inferior to the whites - if the whites are deteriorated by amalgamation with the blacks - if the longevity and physical perfection of the mixed race is below that of either of the pure races, and if the negro is 
by nature unfit for self-government, these are grave matters for consideration" (Nobles 2000:37). If census data could demonstrate that mulattoes could not procreate, they would prove the ideology of Negro and mulatto inferiority. Although there was no conclusive scientific proof that mixed-race persons could not reproduce, this argument continued to be widely used to support punishment of race-mixing until the middle of the 20th century (Gossett 1963, Smedley 2007).

As Jim Crow became established across the South, polygenists' arguments for the separate origin of the Negro, and mulatto inferiority continued to buttress whites' obsession with the maintenance of white racial purity, and to justify racial border patrolling through the one-drop rule (Fredrickson 1971, Myrdal 1944, Smedley 2007). They were used as the basis for the "no-social-equality" doctrine that formed the basis of this legal segregation and especially to support anti-amalgamation sentiment and laws (Myrdal 1944). To further test the polygenicists' theory of mulatto frailty and to determine whether the mixed population was indeed on its way to extinction, categories for "Octoroons" (1/8 Negro ancestry) and "Quadroons" (1/4 Negro ancestry) were added to the 1890 census schedule (Nobles 2000, Thornton 2004). The primary concern was to provide data to support polygenists' objection to race mixing. Results gleaned from census data would be used to explore the degree of racial mixture among blacks, and to determine whether the racially mixed were, as a group, becoming less "mixed" and more "purely black." The presumption was that the mixed population would eventually disappear into the dominant Negro race. The Negro race was considered to be "dominant" only in the sense that any amount of mixture with Negroes resulted in racial 
impurity. In the imagination of race scientists, only blacks and other non-whites might be racially mixed. To be white, one had to be "purely" so (Nobles 2000).

Polygenist arguments gave way late $19^{\text {th }}$ century and early $20^{\text {th }}$ century arguments emerging from Lamarckism, the eugenics movement, and Social Darwinism that attributed human characteristics such personality traits, behavior patterns (especially deviancy) and special abilities to hereditary origins. These assertions were used to further support persistent convictions about white/black differences, black inferiority, and the dangers of racial hybridity. Proponents of eugenics held that various human frailties including diseases, crime, laziness, alcoholism and prostitution were inherited. Deviant behaviors all had genetic causes (Smedley 2007). It is no accident that most supporters of the movement in the U.S. were white middle or upper-class, Anglo-Saxon and educated. The overarching goal of the movement was to improve the (white) race by selective breeding. The prominence of ideas such as these help explain the continued potency of the one-drop rule as the bright and unambiguous boundary that determined the social location of racially mixed individuals with black ancestry.

The work of Mary Douglas (1966) helps shed some light on whites' obsession with patrolling racial boundaries. In her discussion of notions of dirt and pollution in both early and modern societies she argued that dirt is symbolic as "matter out of place." By that she meant that all cultural systems are systems of order and dirt symbolizes disorder, things that do not fit the expected order. All cultures, she argues, contain established systems and patterns that involve clear categorization. The meanings and values attached to those categories are understood and accepted by all. Therefore aberrant phenomena, anomalies, or ambiguities create great discomfort. Societies therefore create provisions for 
dealing with such including: (1) the reduction of ambiguity by choosing one interpretation or another; (2) labeling of anomalies and ambiguities as "dangerous." Though she did not write specifically on race, her insight can easily be applied. In a racially polarized cultural system of white and black, free and slave, any intermediate group or groups such as mixed race people and particularly mixed race people who were not slaves but could not hold the same status as whites "dirtied" the social system. They created disorder and disorder creates in people anxiety. Jim Crow and the one-drop rule served as whites' weapons of boundary-work to remedy those dangerous ambiguities. The one-drop rule, however, as the ultimate tool of boundary-work, was whites' primary provision for dealing with the ambiguity that race-mixing created. The rule placed the racially mixed population in one (black) category ensuring, once and for all, both their separation from and subjugation to whites. Folk ideas buttressed by the scientific "proof" that mulattoes were inferior to both blacks and whites, supported perceptions that they were dangerous. The message: racemixing was deleterious to the white race and was therefore to be prevented; but where it had occurred and where it had resulted in mixed-race offspring, the one-drop rule was to be applied in order to reestablish the social order.

The previous sections examined the social and political processes of boundarymaking that led to the development in the U.S., of race ideology, and to the construction, of the one-drop rule. As was shown, the rule finally crystallized toward the end of the nineteenth century in response to the abolition movement, the Civil War and Emancipation, and the social dislocations accompanying Reconstruction, all of which were challenges to the racial boundaries which had been erected under slavery: white and black. Southern whites responded to these challenges by vigorous boundary-work 
through Jim Crow, anti-miscegenation laws, and the one-drop rule. Even in the North where there were no actual laws segregating the races, de facto segregation with the accompanying social sanctions became the norm (Davis 1991, Myrdal 1944).

Referring back to the key theoretical distinction offered on boundaries by Alba (2003), through the one-drop rule, race again functioned as a "bright" boundary whose parameters were clear and unambiguous - much as it had when it was originally invented during early colonialism. When emancipation and Reconstruction resulted in boundary blurring, Jim Crow was the means by which bright boundaries were restored. Racial segregation with the accompanying anti-miscegenation laws and the one-drop rule continued to characterize U.S. society until the civil rights movement in the 1950 s and 1960s culminated in legislation that dismantled Jim Crow. As the next section will show, racial boundaries are once again threatened when the activism and gains of the civil rights movement permit radical changes through non-European immigration, growing rates of racial intermarriage, and agitation on the part of multiracial Americans for inclusive racial categories on government forms - all factors that pose a challenge to the one-drop rule.

\section{Section 3 - Blurring Racial Boundaries}

\section{The Civil Rights Movement and its Impact}

Civil rights leaders during the 1950s and 1960s argued for legislation designed to ensure equal rights for black citizens. Through various measures including sit-ins, marches, demonstrations, freedom rides and numerous speeches by leaders such as 
Martin Luther King Jr. they launched an extensive and aggressive protest that sought an end to segregation, and equal opportunities for housing, education, employment as well as voting rights for Negroes (Norrell 2005). Civil rights leaders sought primarily to combat the "separate but equal" doctrine upon which Jim Crow had been built and which continued to secure white supremacy until the middle of the $20^{\text {th }}$ century (Norrell 2005). They also countered negative images of blacks that had become popular in the South during slavery and that were transferred North during post-Emancipation migration (Omi and Winant 1994).

Several factors fostered changing racial attitudes among white Americans in the first half of the $20^{\text {th }}$ century, and helped facilitate the success of the civil rights movement (Smedley 2007). Ideas that developed in the wake two World Wars, German Nazism, and demographic changes resulting from a more varied immigrant population were in part responsible for such fluctuation. Of these, most important was the effect of German Nazism. As Americans became more aware of the racist ideology behind Nazi beliefs and as the world learned of the atrocities that had been committed in the name of racial purity, Americans increasingly began to adopt anti-racist attitudes facilitating the success of the civil rights movement (Gossett 1963, Smedley 2007). Thus when Americans fought anti-Semitism abroad, they faced a dilemma similar to the one caused by the American Revolution almost two hundred years earlier (Gossett 1963, Norrell 2005). Additionally, the enlistment of black soldiers in the U.S. military and their participation abroad exposed them to other environments in the world in which were not characterized by racial discrimination. Such exposure increased their expectations for full citizenship within their own country. Moreover, U.S. politicians became increasingly concerned 
about the country's image in the global context, especially after the establishment of the United Nations (Gossett 1963, Norrell 2005).

The civil rights movement resulted in the passage of laws that eliminated "race" as an official and legally sanctioned means of social organization. These new laws destroyed the mechanisms by which racial boundaries had been re-entrenched under Jim Crow, and which had determined social status by enforcing separation of the races, and ensuring unequal access to resources (Norrell 2005, Nobles 2000, Vickerman 2001). In dismantling these barriers, they ushered in yet another era that threatened boundary blurring in the U.S.

Among the outcomes of the civil rights movement that threatened to blur racial boundaries was the passage of the Immigration and Nationality Act of 1965 which resulted in fundamental changes to U.S. immigration patterns. Until 1965 immigration was overwhelmingly European. Although this was not the intention of the government, the Act resulted in a sharp increase in non-European immigrants from the developing world - in particular from Central and South America, the Caribbean, Asia and Africa (Isbister 1996, Lee and Bean 2007). This new immigration has significantly impacted the racial and ethnic make-up of nation that formerly had been primarily black and white. While in 1970 Hispanics and Asians had comprised 5 and 1 percent of the nation's population, by 2005, these percentages had risen to 13 and 4 percent, respectively (Lee and Bean 2007). Not only do these immigrants represent a multiplicity of racial and ethnic groups but they also hold ideas about race and racial identification that reflect social constructions in their home countries. 
Among these new immigrants are black immigrants who comprise approximately seven percent of the foreign-born population and six percent of the black population in the United States (Tormala and Deaux 2006) and who have contributed about twenty-five percent of the growth in the United States black population in the last ten years (Benson 2006). This percentage marks a dramatic increase from the 0.7 percent calculated in 1960. The increasing numbers of black immigrants is likely to contest the ideas about the meanings of blackness that have developed in the United States (Benson 2006, Davis 1991, Hintzen 2003, Rogers 2001, Vickerman 2001, Waters 2001). This is especially so in areas such as New York and Miami, where large concentrations of black West Indians have settled (Rogers 2001, Vickerman 2001). Studies conducted among black West Indians already reveal these peoples' feelings of consternation when they are racialized upon entering the U.S. (Foner 2001, Waters 1999, Vickerman 1999). They report difficulties adjusting to the salience that race (in particular "blackness") holds in everyday experiences. Encounters during which they are victims of racism evoke strong feelings of both shock and anger as well (Foner 2001, Vickerman 1999). Thus along with other non-European immigrant groups, their increasing numbers combined with their different racial worldview has resulted in new blurry boundaries, more complex blurriness that can no longer be accommodated by an outmoded racial binary system. As important a challenge as non-European immigration has been to racial boundaries, an even more significant threat emerging from the civil rights movement was the revocation of anti-miscegenation laws. Since the 1967 case of Loving v. Virginia, in which a black-white couple challenged state laws prohibiting racial intermarriage, and following which the U.S. Supreme Court finally abolished the remaining anti- 
miscegenation laws (Root 2001, Fernandez 2001, Spickard 1989) the number of mixed marriages has accelerated, tripling from 1970 to 1991 from 310, 000 to 994,000 (Davis 1991). Black-white intermarriages are a small fraction of all intermarriages and blacks are still less likely to marry whites than other ethnic groups (Roth 2005). Nevertheless black-white intermarriage increased by 414 percent between 1960 and 1990 - rising from 51,000 to 211,000 (Sanjek 1994). By the year 2000 the number of interracial marriages had climbed to 3.1 million (Lee and Edmonston 2005). The importance of these developments cannot be overemphasized given the centrality that preventing race mixing (especially intermarriage) has held for centuries in U.S. history.

As might be expected, increasing intermarriage rates have resulted in a growing population of mixed-race individuals (Norrell 2005). Between 1960 and 1990, the number of children born of interracial unions increased from 500,000 to 1.5 million (DaCosta 2007). The presence of racially mixed individuals is in some sense not remarkable given centuries of miscegenation in the U.S. But the legalization of intermarriage removing legal, if not ideological, constraints to race mixing, can only serve to further disturb a rigid dichotomy. Importantly, while in the past the one-drop rule restricted such individuals to black racial identity, new ideas about race and identity and the emergence of the multiracial movement have begun to pose a challenge to the rule. The next section discusses the emergence and arguments of the movement and the likely impact of their gains for racial identification and the one-drop rule. 


\section{The Multi-Racial Challenge to the One-Drop Rule}

Yet another outcome of the dismantling of Jim Crow, and a crucial challenge to

the one-drop rule, was the emergence of the multiracial movement in the late $20^{\text {th }}$ century (Fernandez 2001). Initially led primarily by parents of mixed-race offspring, members of the movement claimed the right to report all races in one's background which they believed was a basic civil and human right (Davis 1991, Daniel 2004, Fernandez 2001, Root 1996, Williams 2006). The movement began in the late 1970s when a number of concerned intermarried couples and mixed individuals formed local state organizations designed to foster community and provide opportunities for socialization (Fernandez 2001, Williams 2006). Members were brought together by shared experiences of outright racism, and thinly veiled disapproval (Dalmage 2000, Williams 2001) and simply by the need to find a safe place for them and their children (Williams 2006). Parents were also particularly opposed to school forms that forced their children to choose one a single racial category. Many complained of adverse effects on their child's self-esteem. By choosing one racial identity, the child was being forced to acknowledge the existence of one parent while virtually denying that of the other (Spencer 1997, Williams 2006).

Members of the movement therefore formed several multiracial organizations whose shared concern was the creation of an official government classification of "multiracial" or "biracial" that would permit the inclusion of the two or more racial ancestries borne by them and their children (Fernandez 2001, Spencer 1997, Williams 2006). The organizations thus lobbied for modification of the U.S. Census Bureau's Directive No. 15. Established in 1977 as the official standard for collection of ethnic and racial data, Directive No. 15 had created five racial and ethnic categories: black, white, 
Asian/Pacific Islander, Hispanic and Native American/Alaskan Native). In response to the multiracial movement's demands the Office of Management and Budget (OMB) proposed that a category of "other" be added to facilitate racial identification for individuals who did not fit into those established in 1977. Many multiracial individuals also called for an additional category of "multiracial" or "biracial” (Daniel 2004, Fernandez 2001).

Despite being under-funded and loosely organized, and despite holding divergent views, the movement's leaders enjoyed some success. A "multiracial" category was added to school forms in thirteen states: six of which passed multiracial category legislation between 1992 and 1998; Florida and North Carolina added a multiracial designation by administrative mandate and legislators introduced multiracial category bills in Minnesota, Texas, Oregon, Massachusetts, and California (Williams 2006). On the national scene, the AMEA $^{6}$ appeared before Congress in 1993 to formally request an additional category "multiracial" on census forms. Though their request was not approved, allowance was made for the first time in U.S. history, for individuals to check one or more categories on the census forms.

While still restricted to existing racial categories, this new option opened the door for new identifications that challenge the one-drop rule. In the 2000 census, 6.8 million Americans selected more than one race in response to the race question. This figure and the continued efforts of multiracial organizations, some of which are still hoping for the "multiracial" identifier to be added to census schedules, suggest the possibility of an environment for new ideas about racial identity (Williams 2006). In fact, scholars (Davis

\footnotetext{
${ }^{6}$ The Association of MultiEthnic Americans (AMEA) was the first national multiracial organization, formed in 1988. The AMEA was intended to serve as an umbrella organization for the more than fifty local groups that were operating across the nation (Daniel 2004).
} 
2001, Williams 2006) speculate that in the long term the movement's efforts will likely result in an end to the one-drop rule.

Recent studies demonstrating that black-white mixed-race individuals are choosing from a variety of racial identification options, serve to further suggest that the country's bright boundary - one-drop rule - is becoming "blurry" (Brunsma 2005, Rockquemore 1999, Roth 2005). In her study of biracial students at the University of Notre Dame, Rockquemore (1999) argues that there are four possible paths for racial identity including: a biracial or "border" identity; an exclusively black or "singular" identity; a contextual choice of black, white and/or biracial or "protean" identity; and a "transcendent" or no racial identity. Of the total sample, more than half (55 percent) chose the "border" or biracial identity. Similarly, Roth (2005) finds that most multiracial families are rejecting the one-drop rule.

As Roth (2005) points out, however, most children born to black-white couples were given interracial identities. The fact is that crossing the color line is more difficult for people with black ancestry than it is for other racial groups (Lee and Bean 2007, Roth 2005). Of all racially mixed children, those with black ancestry are the least likely to be assigned identity as white. Had the one-drop rule lost its potency, more of such children might have been assigned identity as white. For these children the choice of an interracial identity, is a means of getting around boundaries, rather than an indication that they have been dismantled (Roth 2005). 


\section{Why the One-Drop Rule Persists}

Thus Non-European immigration, increase in racial intermarriage and the burgeoning multiracial population that increasingly reject the one-drop rule raise questions about the salience of the black-white color line. Yet the rule continues to be generally supported by Americans. There are several reasons. Among the most significant of these is that the rule is supported by the African American community. While blacks have fought to destroy the barriers that blocked their access to resources, the one-drop rule itself was rarely challenged after the 1920s until the appearance of the multiracial movement. Black racial identification, as mentioned before, had become an important rallying point for mobilization of African Americans, particularly during the civil rights era (Rogers 2001). Blacks, in fact, opposed the changes proposed by the multiracial movement (Daniel 2004). Civil rights groups and individual African-Americans feared that since most blacks are of mixed origin, the creation of a separate racial category would result in the reduction of the African American population. Census data had been used since civil rights to monitor adherence to laws governing equal employment, and housing, and to determine government funding for schools and important community organizations. A reduction in the number of African Americans was therefore likely to reverse the gains of the civil rights movement (Daniel 2004, Williams 2006).

Blacks, albeit for reasons that are very different from those of whites, have therefore conducted their own version of border patrolling. Black boundary-work has occurred through the "roots" movement to trace heritage back to specific tribes in Africa (Adeleke 2005). Movements and groups such as Black Power, the Black Panthers, and Afrocentrism that have fostered "black pride" and black mobilization in the struggle for 
equality have also, most likely unintentionally, resulted in the continued reification of both “race" and the one-drop rule (Adeleke 2005, D'Souza 1995). Blacks have also continued to oppose interracial relationships and transracial adoptions that involve adoption by white parents of racially mixed children and/or black children (Davis 1991, Dalmage 2000).

Blacks are, of course, not alone in contemporary boundary-work. Border patrolling occurs on both sides of the color line (Dalmage 2000). The fact that despite the growing number of interracial marriages, the out-marriage rates of blacks remain quite low demonstrates the potency of border patrolling to prevent intermarriage with blacks. White border patrolling through racism has persisted, and blacks (and other minorities) have continued to experience various forms of discrimination (Feagin 1991, Bell 1993, BonillaSilva 1997, Haney-López). Racism, as several scholars (Bell 1993, Feagin 1991, HaneyLópez 1996, Sanjek 1994, West 1993) have shown, is no longer legal, but has continued to be institutionalized. Every-day boundary work occurs in public places (restaurants in which waiters seat white customers and ignore blacks, white clerks who refuse to put change in the hands of black customers, black middle-class professionals who experience discrimination in the form of "hate-stares" or police harassment while out jogging or walking in their neighborhoods) - racism remains a major problem (Bell 1993). And redlining in the housing market has been a primary means of maintaining the color line to present day (Douglas 2000, Massey 2007). The failure of civil rights legislation to eliminate de facto racism led Omi and Winant (1994) to conclude that race will always be at the center of American life. Race, as a cultural construct, remains a salient. Civil rights legislation dismantled the mechanisms through which boundaries were patrolled, but they have not eradicated the cultural and ideological boundaries centered on race. 
Thus despite challenges posed by post-civil rights changes, the one-drop rule remains salient. As Daniel (2004: 282) put it, "the one-drop rule is the linchpin of the U.S. binary racial project. It has become what Pierre Bourdieu calls doxa, a sacred, sacrosanct, and unquestioned social concept or dogma." As a cultural construct it remains rooted in the minds of most Americans

Several key developments in the post-civil rights era are blurring formerly bright racial boundaries thereby placing pressure on the black-white binary (Fernandez 2001, Vickerman 2001). Post-1965 immigration has led to a significant increase in non-white (in many cases, multiracial) immigrants who come from countries in which there is no onedrop rule. Civil rights legislation abolishing anti-miscegenation laws has facilitated an increase in racial intermarriage, a growing population of mixed race offspring, and the multiracial movement that has secured the ability to officially incorporate all races represented in one's ancestry. Recent research reveals different paths for racial identification among the racially mixed, further indicating increasing rejection of the onedrop rule. These developments combine to suggest the possibility that U.S. society is slowly moving away from the race ideology that led to the development of the one-drop rule and, perhaps, toward its eventual eradication.

As I have shown, however, the one-drop rule is still largely intact. The above developments certainly raise questions about the likelihood that a rigid racial binary can persist in the long term. But the concept, "blurred boundaries" implies greater fluidity than currently characterizes the U.S. racial system. The boundaries are weakening; but any blurring that is occurring is limited rather than pervasive. Race and the one-drop rule remain salient. 


\section{Chapter Conclusion}

In this chapter, I described the social construction, through boundary-work, of a racial dichotomy in which the one-drop rule has functioned as a bright boundary between blacks and whites. Prompted by concerns about class concerns, and by their obsession with maintaining racial purity, various sectors of white society (politicians and law makers, law enforcement officers, census workers, and lay individuals) have exerted great effort in the construction and management of racial boundaries. While the boundaries drawn by race and the one-drop rule have been contested and blurred at various junctures of U.S. history, white boundary-work has seen to their reconstitution. Thus, although at first not uniformly applied across the entire country, the one-drop rule came to be accepted by all (including blacks) by the early 20th century (Davis 1991). And despite divergent views regarding racial identity exemplified by the efforts of the multiracial movement, the rule continues to guide Americans' ideas about racial identification.

While the one-drop rule still persists, the arrival of large numbers of nonEuropean immigrants, representing a variety of racial and ethnic ancestries, raises questions about the persistence of the black-white racial dichotomy. Many of these new immigrants are black and they enter the U.S. with racial worldviews that reflect understandings of race and blackness that were developed in their home countries. The next chapter focuses on one such group: Jamaicans--the immigrant group that is the focus of this dissertation. Unlike the rigid racial dichotomy that was constructed in the U.S., Jamaica evolved a complicated and much more fluid color hierarchy (Lowenthal 1971, Henriques 1968, Vickerman 1999). This more fluid hierarchy implies that blurred, rather 
than bright racial boundaries characterize that society. In short, race boundaries and along with them, racial identifications, have evolved differently in these countries. Jamaican immigrants therefore enter the United States with ideas about race and racial identifications that reflect a Jamaican racial worldview. The next chapter explores the factors that led to the construction of this different racial worldview. 


\section{CHAPTER III}

\section{The Social Construction of a Color Hierarchy in Jamaica}

In Jamaica, like in the U.S., contemporary racial boundaries have origins in colonial times. While Jamaican boundaries also emerged from a historic bright boundary between slave and free persons, very different processes of boundary-making, boundaryblurring, and boundary shifting, have led to the construction of a more complex color hierarchy. Thus, despite sharing with the U.S. similar circumstances of European colonialism and enslavement of Africans and their descendants, race has been constructed differently in Jamaica. Jamaican immigrants therefore enter the U.S. possessing notions about race and racial identification that reflect those cultural constructions formed in their home country. This chapter explores the primary factors that led to these different cultural constructions of race. In so doing it explains why, rather than a racial dichotomy, Jamaica evolved a tripartite color hierarchy under slavery. That is, the chapter explains how and why instead of a one-drop rule that draws bright boundaries restricting racial identification and determining social status, Jamaica constructed complex notions of color that permits more fluidity with regard to race.

Race and racial identifications in Jamaica are social constructions, erected through the boundary-work initially of the dominant white elite, and later, increasingly also by dominated black and racially-mixed groups. Similar to the U.S., race initially drew bright boundaries in Jamaica; but the current situation is characterized by both the shifting and blurring of boundaries. Exploration of such boundary-work and its impact on notions about race, color, and social status in Jamaica, provides a much needed explanation for a different construction of race on the island, and for the more complex 
understandings of race that my racially mixed participants hold and which they take with them to the U.S.

Several factors are identified as bringing forth this different construction of race and these factors are thoroughly explored in their historical context. They include: (1) the higher ratio of blacks to whites (2) the huge decline in the white population and active boundary-construction processes (3) integration of other groups into intermediate (not white) social strata (4) intermarriage and race-mixing (5) internal boundary-work of "browns" to maintain a historical distinction from blacks and (6) black social mobility.

\section{Clarification of Terms: Color and Race}

I wish to clarify my use of "race" and "color" in reference to Jamaica. "Race" here, denotes racial categorization and refers to groups identified in Jamaica as white, black, Indian, Chinese for example (Smith 1974). I recognize that skin color is and has long been the primary indicator of race. But in the Jamaican context color has evolved into a much more complex construction as the chapter shows. Thus, "color," as used in Jamaica, refers to a combination of skin color, hair type or texture, facial features all of which emphasize degrees of distance from those normally associated with people of African descent and nearness to those associated with people of European descent. Extensive intermixing in Jamaica and the Caribbean and complex interrelations of race, social status and color further complicate notions of color on the island. Consequently, my use of color conforms most closely to that of M.G. Smith (1974: 60) as follows, "As normally used in the British Caribbean, the term 'color' connotes a combination of physical characters, such as skin-color, hair-type, form of facial features, prognathism or 
its absence, so forth. . . In British West Indian colonies there is a clear overt rank-order of different phenotypical colors in terms of a prestige scale, which places white phenotypes at the highest and black phenotypes at the lowest points." Smith goes on to explain that notions of color are often influenced by behavior patterns. "Thus, in Jamaica for example, there is a set of expectations which define the behaviors of whites, browns, and blacks. In terms of these expectations, a white person whose behavior conforms more closely to that of the brown population is culturally brown. Similarly, a pure Negro may be culturally white or brown, which simply means that his behavior is analytically homologous with that distinguishing these color groups as cultural groups" (Smith 1974: 63-64). By this definition, color, in Jamaica, and indeed in much of the English-speaking Caribbean, incorporates various distinctions of complexion and phenotypes within racial groups, racially mixed Jamaicans, and behavior patterns (such as, speech including ability to speak English rather than only the Jamaican patois, "good" manners, etc.) normally associated with specific racial or cultural groups.

It is important to distinguish between race and color because in the Jamaican context they are both salient and separate concepts that have, over time, drawn both symbolic and social boundaries, as well as bright and blurry boundaries. Color, however, currently takes precedence over race proper in social organization (Henriques 1968, Smith 1974). That is, while the importance of racial distinctions has diminished over time, and to a great degree has disappeared from daily discourse, differences in color have become more important and are currently still openly discussed.

The chapter is divided into three sections which cover three periods of Jamaican history. The first period begins with the arrival of the English in 1655 and ends with 
emancipation in 1834. The second period covers the post-emancipation era to independence in 1962. And the third period focuses on developments in Jamaica since independence. The first section discusses the factors linked to the plantation system that produced a tripartite social hierarchy that was based on color, and in which "white" was at the top, "black" at the bottom and "brown"" (mixed) an intermediate category. The second section examines several developments that after emancipation both solidified the intermediate position of browns and that caused the rigid pyramid-like social structure to become transformed into a more fluid color hierarchy. The third section examines social transformations since political independence in 1962, the relationship between color and class, and the place of the racially mixed in all of this.

\section{Section 1 - Construction of Bright Boundaries: Formation of a Tripartite Color} Hierarchy During Slavery (1655 to 1834)

\section{African Slavery and The Beginnings of Race Ideology}

Africans slaves were first taken to Jamaica in the early $16^{\text {th }}$ century by the Spanish who colonized the island from 1509 to 1655 . Under Spanish rule, exposure to European diseases and unfamiliar labor had virtually decimated the indigenous Arawak population, making it necessary to find labor from other sources (Headley 1984, Sherlock 1998). The colonial social system based on the racial dominance of Africans by

\footnotetext{
${ }^{7}$ In Jamaica black-white mixed race individuals were known as "coloreds" during and after slavery. "Colored" was replaced by the term "brown" during the early-to-mid $20^{\text {th }}$ century and is now widely used in daily parlance. Since "brown" is also the term currently used by Jamaican scholars, I have chosen to use it throughout the entire chapter, except in direct quotes which use another term (usually "coloreds" or "coloureds."
} 
Europeans, thus began under the Spanish. Relations between African slaves and Spaniards on the island were, however, comparatively benign (Sherlock and Bennett 1998). There had been no large plantations on the island while under Spanish rule. Most holdings (farms or ranches) were small and produced crops (such as cocoa, plantains, and cassava) that required no more than two or three slaves to maintain them. Many masters worked in the fields cultivating these crops alongside their slaves. In time "a trust developed between them to the extent that on occasion slaves were allowed to carry arms in defence of the island" (Sherlock and Bennett 1998:75).

It was under the English that severe practices geared toward degrading and dehumanizing African laborers began to occur (Sherlock and Bennett 1998). The African population had remained very small comprising only one-fourth of the entire population of 6,000 when the Spanish were ousted by English colonizers in 1655. Under English rule, however, the cultivation of large sugar estates needing a massive labor force ensued. And as the plantation system became central on the island, slavery there took on a more sinister character, with the slave being considered no more than mere property and the institutionalization of race as the primary means of social organization.

As in all European colonies in which the plantation economy relied on African slaves for labor, racist notions about white superiority and black inferiority served as the justification for slavery in the West Indies (Headley 1984, Henriques 1968, Lowenthal 1971). To ensure retention of their political and economic power, and to maintain white supremacy, whites relied upon the persistent subjugation of all non-white groups (Headley 1984). Folk ideas about the inherent inferiority of non-Europeans in general and Africans in particular, supported by scientific theories saw to the ratification of race 
ideology on the island during slavery as they had in the U.S. Plantation society therefore involved processes of socialization that resulted in the acceptance of these ideas by all its members - black, and white, slave and free (Henriques 1968). It would become "natural" to link both race and color with status. Therefore, even blacks who had been manumitted or were born free experienced subjugation in the form of laws designed to disenfranchise and to restrict their access to civil liberties (Campbell 1976).

Also, as occurred in the United States, miscegenation during slavery in Jamaica was widespread; but unlike most of the U.S. (except Charleston and New Orleans) the rapidly growing mixed progeny were accorded the status of an intermediate group between blacks and whites. While racially mixed individuals were largely held in disdain by the white elite, they too denigrated blackness and exalted whiteness reflecting the "white bias" that came to characterize attitudes of blacks, and browns during slavery (Nettleford 1970, Henriques 1968). Thus members of hybrid populations, though experiencing rejection from both groups (black and white), were likely to "strive for the impossible, that is, for complete identity with the white group" (Henriques 1968: 52).

Whereas civil status (slave or free) initially determined one's social status, race and color quickly became the primary determinants of individuals' location in the social hierarchy. Plantation society evolved a tripartite color hierarchy with a pyramid-like structure. At its apex was the dominant white minority (Lowenthal 1971, Vickerman 1999). Blacks who comprised the majority of the population fell at its base while the offspring of white-black relationships (for much of Jamaica's history referred to as "browns") comprised the intermediate group (Campbell 1976, Lowenthal 1971). In reality the structure was much more complicated since within each stratum of the 
hierarchy further stratification was done based on both color and occupation (Vickerman 1991). Yet through boundary-work, whites ensured that boundaries were drawn between the three primary groups in terms of how the society and institutions functioned.

During slavery, boundary-work, primarily on the part of whites, ensured that their lives were separate from that of free browns and blacks (slaves were, of course, separated by their status as property). Holding both browns and blacks in contempt, whites prohibited the admission of the children of free browns to the island's public schools, the admission of blacks and browns to events planned for whites, and in churches and the theater seating was segregated based on color. These divisions were institutionalized and widely practiced. The result was that the three groups led separate lives. “...blacks had their own life in town and on plantations, the wealthy free coloureds had theirs, mainly in the large towns, and the whites had theirs" (Brathwaite 1971: 186).

It was within this framework that, rather than a racial dichotomy buttressed by the one-drop rule as in the U.S., Jamaica constructed a complicated color hierarchy involving degrees of color (Henriques 1968, Lewis 1985, Lowenthal 1971, Zarembka 2007). And with a great deal of modification, that color hierarchy has persisted to a great extent until today. So although permitting much greater fluidity, one may say that that Jamaica is, "divided into three social sections...the white, the brown and the black, this being the order of their current and historical dominance, and the exact reverse of their relative numerical strength" (Smith 1974: 163). Within these three social sections there are hierarchies of skin complexion in which lighter hues are generally ranked more highly than darker hues. This is why race in Jamaica is often described as a complicated continuum involving degrees or gradations of color (Lewis 1985, Lowenthal 1971). As 
such it stands in contrast to the U.S. racial dichotomy by which gradations of skin color make very little difference outside of the African American community ${ }^{8}$. In Jamaica, however, they are important.

In Jamaica color has taken on a fluid character that has further complicated ideas about race on the island, since "color" as a symbol of status is not based only on phenotype but also on culture, behavioral patterns (such as speech habits), achievements, and socio-economic status (Lewis 1985, Lowenthal 1971, Smith 1977). This complex social construction of "color" is summarized in the popular phrase "money whitens" - a phrase that usually indicates the possibility of being perceived as socially (if not, racially) "white" by virtue of having achieved social mobility through higher education or success at business (Lewis 1985, Lowenthal 1971). Jamaica's color hierarchy and notions about color and status are rooted in historical processes that began under slavery. The following section of this chapter examines the forces, which under slavery, led to their emergence.

\section{The Impact of Demography}

Demography, in particular the existence of a small number of whites compared with a very large black slave population, explains much about the development of Jamaica's color hierarchy (Bryan 1991, Curtin 1955, Lowenthal 1971, Vickerman 1999). The white population already quite small at only 3,600 at the beginning of the period of

\footnotetext{
${ }^{8}$ While organized as a complicated color hierarchy rather than a black/white racial dichotomy, Jamaica's racial system does, of course, still reflect a black-white axis. Not only does the color hierarchy ranks lighter hues over darker ones, but, as is shown later in this and the next chapter, power and prestige continue to be associated with those possessing lighter complexions. Moreover, while distinctions made based on race and color in Jamaica are "diffuse rather than sharp" (Vickerman 2001:240), the fact that they are made is indicative of the ways in which the black-white racial poles are still at work in Jamaica - even if in covert, rather than overt ways.
} 
English settlement, experienced rapid and continuous decline in proportion to the entire population (Alleyne 2002). Between 1662 and 1692, the white population fell from 86.8 percent of the population to 15.3 percent (Burnard 1996). In 1739 the black-white population ratio stood at approximately 10:1 with a count of 99,000 Africans and 10,000 whites (Sherlock and Bennett 1998). In fact, that 10:1 ratio of blacks to whites was to continue for much of the slave period (Brathwaite 1971).

The small size of the white population was, in part, due to high rates of absenteeism among planters many of whom left the island with their families, placing accountants or overseers in charge of their plantations (Bryan 1991, Sherlock and Bennett 1998). Unlike the United States, British West Indian territories did not become settler societies (Brathwaite1971, Burnard 2002, Franklin 1967, Lowenthal 1971). Rather, they were sites from which Europeans aimed to quickly procure wealth from the gold and other precious metals as well as from agricultural cultivation on large plantations so that they could live comfortably in their home lands (Brathwaite 1971, Segal 1995). Absenteeism occurred from the earliest periods of English settlement of Jamaica and increased over time so that by emancipation more than eighty percent of the sugar plantations were owned by absentees (Sherlock and Bennett 1998).

Other reasons that explain the declining white population include fear of natural disasters such as hurricanes and earthquakes, external threats from Spain and France, and fear of slave insurrection. But perhaps the most important factor was the white death rate which was so high that Jamaica was considered a "killing grounds" for whites, thousands of whom died between the late $17^{\text {th }}$ and early $18^{\text {th }}$ centuries (Burnard 2002: 80). The death rate of Europeans was much higher than that of Africans so that "newly arrived 
young European adults died at about four times the rate of newly arrived Africans of the same age" (Burnard 2002: 80). Most of these deaths occurred as a result of the 1692 earthquake that sank the town of Port Royal, killing close to 2,000 people and that brought with it an outbreak of malaria (Dunn 1972). The steady arrival of un-acclimated whites, lacking immunity to tropical diseases, led to later outbreaks as well (Bernard 2002, Dunn 1972). At the same time that the white population was falling, the black population was rising as large numbers of African slaves were imported to supply labor for these plantations (Campbell 1976, Dunn 1972). The preceding facts combined with the white exodus to England, quickly led to the demographic breakdown described above (Campbell 1976, Sherlock and Bennett 1998).

Miscegenation, Freed Browns, and the Status of Mixed Progeny (Slave and Free)

Similar to other slave societies, miscegenation between blacks and whites was widespread. In large part this was due to the absence of English women. But in addition to fulfilling sexual desires, the use of black and brown women by white men was a matter of power. Most of the race mixing that occurred consisted in the taking by force of the "most comely" slave women by slave masters (Campbell 1976, Henriques 1968). As in the U.S. white men "took" slave women with or without their consent - because they could; and resistance of unwanted advances resulted in severe punishment (Campbell 1976). Among the various forms of exploitative unions between white planters or overseers and slave women, was the taking of female black (and later brown) slaves as concubines or "housekeepers" as they were called (Campbell 1976). 
Yet force on the part of the planter or overseer was not the only reason for the prevalence of concubinage. To slave women, concubinage was often perceived as advantageous as it provided relief from field labor; it also offered special privileges including the possibility of manumission for themselves or their children (Henriques 1968). The brown female who became housekeeper for a white male was considered by other browns and blacks (often members of her family including her mother) to have done well (Campbell 1976). Miscegenation was therefore encouraged by slaves themselves seeking better conditions for themselves or relatives. That is, the belief that concubinage elevated one's social status contributed to growing rates of race mixing as well.

The result of such widespread mixing was a quickly growing mixed-race population that soon far outnumbered whites (Campbell 1976). Since the dominant race ideology held to the superiority of whites, these mixed offspring, who were tainted by their black parentage, were generally considered inferior stock and accorded the status of slaves. However, quite frequently many were granted preferential treatment, removed from the field and assigned domestic duties (Campbell 1976, Henriques 1968). Regardless of their assignment members of the mixed-race slave population demonstrated a tendency to consider themselves superior to black slaves. Light skin, even among slaves, was given high value; dark skin was denigrated (Campbell 1976). Their color and their white heritage were so important to them that brown slaves considered themselves to be superior even to free blacks.

The emergence of a racially mixed population, though caused by whites themselves, was a source of embarrassment to whites (Campbell 1971). The prevalence 
of miscegenation and the fact that white men drawn from all ranks of the white population (from governor to overseer) were involved was, to many whites, the reflection of moral breakdown. Their consternation is expressed in this comment by J.M. Phillippo: "Unblushing licentiousness, from the Governor downwards throughout all the intermediate ranks of society, was notorious in the broad light of day" (Campbell 1976: 26).

Ideas about race mixing were, of course, no different from those that were being circulated in the U.S. at the same time. One of the primary reasons behind objections to miscegenation in Jamaica was the fact that racial mixing blurred the racial distinctions and, therefore, those boundaries that were so important for the maintenance of the social ranks (Campbell 1976). And as in the U.S. whites sought to deal with problem posed by a rapidly growing mixed population by disseminating ideas about the inability of racially mixed individuals to procreate. These notions were quickly dispelled by the bourgeoning population of browns who, of course, continued to reproduce.

Largely because of the continued paucity of white women on the island, race mixing continued to occur on a large scale, despite these objections. And although many of the mixed offspring were relegated slave status, a large number of white fathers evidently manumitted or sponsored the manumission of their mixed offspring. Brown domestic slaves and concubines were also frequently manumitted. The result was a rapidly increasing and progressively assertive population of freed browns - a particularly significant factor behind the development, in Jamaica, of a tripartite color hierarchy during slavery (Campbell 1976, Davis 1991, Henriques 1968). The fact that before emancipation free Negroes and free brown were often classified together makes an exact 
count of the latter impossible. However, it is estimated that in 1791 there were 10,000 freed Negroes and browns; at the time there were approximately 30,000 whites (Henriques 1968). By the time of the first census in 1844 the brown population had risen to 68,529 while the number of whites stood at 15,776 (Campbell 1976).

The large number of free browns was a source of great concern to members of the diminishing white elite who, feeling their high status threatened, made every effort, through boundary-work, to restrict their social and economic advancement (Curtin 1968, Campbell 1976). Whites erected bright boundaries by passing a number of restrictive laws including the 1711 act that prohibited all non-whites (including Jews who at the time were not considered "white") from being employed in any public office on the island, and deficiency laws that established a minimum number of whites in proportion to the number of slaves on each plantation (Burnard 2002, Campbell 1976). These laws were particularly restrictive as they prevented free browns from being employed as accountants, or bookkeepers on plantations (Campbell 1976). Free browns were prohibited from voting, serving as jurors and holding military officers' commissions (Davis 1991, Campbell 1976). Additionally, limits were placed on the amount of property that could they could inherit from white persons (Davis 1991). Whites also excluded browns from private social gatherings such as formal balls and dinners. Browns, moreover, could not enter the theater by the same door as whites or sit with them inside (Heuman 1976). 


\section{Free Browns Become "Buffer"}

Nevertheless, in comparison to the experience of mixed-race persons in most of the Southern U.S. during the same period, the brown population in Jamaica enjoyed a relatively favored status. That status privileged freed browns over unmixed blacks, both those who were slaves and those who were free (Brathwaite 1971, Campbell 1976, Davis 1991, Henriques 1968). The fact is, in the eyes of the white elite, while browns' black "blood" rendered them inferior in the minds of whites, their white ancestry made them somewhat more acceptable than unmixed blacks. Thus, in spite of increasing white resentment of browns, the insignificant size of the ruling class compared with the bourgeoning slave population, prompted their treatment of the brown group as distinct from and superior to pure blacks (Campbell 1976, Heuman 1976). In the face of a rapidly increasing black slave population browns served as an important buffer group between blacks and whites (Campbell 1976, Curtin 1955).

For more than a century and a half browns made no collective effort to improve their condition. It seemed that they accepted their intermediate position in the color hierarchy including their inferior status to whites (Campbell 1976). By the early years of the nineteenth century, however, their apparent deference was to disappear. A number of factors that had facilitated their favored status also fueled the ambitions of browns. Many had been educated - often in England - and some had also inherited property from their white fathers. Those who had been educated in England had often been treated by whites as equals there. These experiences and privileges only increased their desire for equality with whites (Campbell 1976, Davis 1991, Henriques 1968). 
In the wake of the Haitian Revolution of 1804, humanitarian sentiment and activism in Britain, as well as the decline in the plantation system and their own increasing wealth, browns in Jamaica began to challenge boundaries to their social mobility by demanding that legal restrictions be abolished. Taking advantage of proabolition arguments, browns petitioned the Jamaican Assembly for an extension of their rights (Brathwaite 1971, Campbell 1976). They argued that of the three racial groups on the island, they were the only "true Jamaicans" and the "rightful sons of the soil" as theirs was the only group that had been produced by the peculiar circumstances of colonial life. As "true Jamaicans" they claimed that they deserved special concessions (Campbell 1976, Nettleford 1970). By 1830 their efforts had been successful as the Assembly passed a privilege bill which declared that free browns, "shall be entitled to have and enjoy all the rights and privileges, immunities and advantages whatsoever they would have been entitled if born of and descended from white ancestors."(Campbell 1976: 140) By this bill then, browns were granted full civil rights and a measure of political power as well, being enfranchised and taking seats in the assembly (Campbell 1976, Heuman 1976).

The efforts of browns to dismantle social and political boundaries drawn around them had achieved results by 1830 , three years before the passage of the Emancipation Act in 1833, and four before it took full effect in 1834. These changes indicated that boundaries were beginning to blur for browns. Blurring of those boundaries would permit consolidation of their intermediate status in the social hierarchy throughout the rest of the $19^{\text {th }}$ century.

It is important to note that certain whites (especially the planter class) did not support browns' demands for equal rights. Those white planters who supported removal 
of restrictions were concerned about attacks against slavery and believed that browns would join them in defense of the institution. In fact, between 1823 and 1830 when brown activism intensified, several white members of the Assembly argued vehemently against the changes they demanded. Had it not been for intervention from the Imperial Parliament that bill may never have been passed. Thus though granted all the rights of free men, browns as a group were never accepted as whites. Rather, browns were largely still held in disdain by whites and continued to be excluded from white society. For example, practices barring browns from formal white social events such as balls, continued to occur. As a group, browns were thus not able to realize their desire for equality with whites.

Despite a blurring of boundaries occasioned by the 1830 Privilege Bill, the pyramid-like structure based on color had not been fundamentally transformed. Browns, disdained by whites, in turn disdained blacks. So, although the 1830 bill had also blurred boundaries for free blacks, browns continued their boundary-work reinforcing the borders separating them from the latter. Among the various examples of such boundary-work was the refusal of browns to collaborate with free blacks in the area of politics (Heuman 1976). Since they were excluded from white society and since they rejected association with blacks, browns carved out social activities (lively and expensive balls, and dinners) which were exclusively reserved for their own group.

While during slavery race and color drew bright boundaries determining social locations for both browns and blacks, these boundaries began to soften for browns particularly in the early $19^{\text {th }}$ century. Browns' disdain for, and their boundary-work against, blacks (slave and free), ensured their separation from the group located on the 
lowest rung of the social ladder. The small and declining white population coupled with a growing population of browns, permitted browns, many of whom benefited from education and inheritances, to achieve a position of relative importance. It is for these reasons that, unlike the in United States, browns in Jamaica became a separate and intermediate group between the white elite and black slave during slavery. Moreover, the passage of the 1830 Privilege Bill fostered brown social advancement so that after emancipation, browns began to emerge as an influential group that would later play an important role in the shaping of Jamaican society (Lowenthal 1971). As the next section will show, rapid decline in the white population after emancipation and reduction in the power of whites, led to blurring of boundaries drawn by color, and created the opportunity for further social, political, and economic advancement of the brown group.

Section 2 - Boundary Blurring: Color and Social Status from Abolition to the Independence (1834 to 1962$)$

\section{Loss of Labor and Decline of the White Planting Class}

The loss of dependable slave labor after abolition proved devastating for plantations and is in large part responsible for the further decline in Jamaica's white population. In an attempt to ensure a regular labor supply after the abolition of slavery, the British Crown government had established an "apprenticeship system" whereby exslaves, they argued, would acquire the qualities of industry and thrift that the white plantocracy believed they lacked and that would prepare them to continue to work for former owners on plantations (Bryan 1991, Campbell 1976, Curtin 1968). The 
apprenticeship system failed, however, and was abandoned in 1838 (Curtin 1968).

Government policy regulating apprenticeship permitted any apprentice to leave the plantations, if desired. Assisted by non-conformist missionaries who provided financial support, many chose to do so and establish their own small farms (Curtin 1968). Motivation to leave plantations also came from various forms of abuse on the part of planters and overseers.

The labor shortage thus worsened after the end of the apprenticeship system in 1838. Contrary to the expectations of humanitarians but fulfilling the predictions of the white plantocracy that emancipation would spell doom for the plantation system, full emancipation created new problems. While a few ex-slaves continued to work on plantations for wages, most chose to forsake plantations which were potent reminders of bondage. They purchased or squatted on available land, and settled in "free villages" (Bryan 1991, Curtin 1968). Missionaries, particularly from Methodist and Baptist churches, provided assistance to ex-slaves who lacked the financial resources needed to purchase land and manage small local plantations (Campbell 1976, Curtin 1968). Land owned or settled by this new peasant class expanded rapidly so that between 1841 and 1860 the number of holdings under forty acres had grown from 7,919 to 50,000 (Bryan 1991). Consequently, while plantations were falling into ruin, these settlements were growing in number and becoming increasingly important to the island's economy (Curtin 1968).

The determination of former slaves to leave the plantation demonstrated their desire for independence and challenged racist notions held by the white elite about the Negro's need of slavery and the "care" of the master (Campbell 1976). It was also a 
reflection of their desire to dismantle social boundaries that were drawn against them on the basis of color. While assistance from churches was instrumental to their achievements, their success at cultivating and marketing crops was also attributable to their ability to make use of experience gained during slavery. It had been customary in Jamaica (though not in most other West Indian colonies) for planters to provide land on which slaves could cultivate crops for sale (Campbell 1976, Curtin 1955). Ex-slaves took advantage of this experience in their efforts to achieve socio-economic mobility and, especially, independence from their former masters. Thus, ex-slaves' largely through their own initiative and industry, supported by missionaries, were able to transform themselves into a new and thriving black peasant class.

The decision of ex-slaves to leave the plantations is in part responsible for further decline in the white population. The resulting labor shortage proved devastating for sugar plantations which required large numbers of workers to perform the myriad tasks involved in sugar production. Despite the urging of planter interests in Britain, Jamaican planters had continued to employ archaic tools (such as the hoe) rather than more advanced tools (such as the plough) that might reduce the amount of human labor needed on plantations (Campbell 1976). To supplement the labor supply planters turned to Europe, China and India in search of indentured servants (Campbell 1976, Sherlock 1998). In spite of such importation, plantations crumbled as their owners abandoned the island. Moreover, the passage in 1846 of the Sugar Duties Act that removed preferential tariffs West Indian colonies had previously enjoyed, spelled ruin for many white plantation owners. As plantations closed and many planters returned to England with their families, the white population experienced further decline (Campbell 1976, Curtin 
1968). Between 1891 and 1911 the white population declined from 2.29 percent to 1.88 percent (Bryan 1991).

Boundary-Blurring Continues: Rise of the Brown Class and Black Social Mobility

The declining white population created an opportunity for the already influential brown population to experience additional social advancement (Bryan 1991, Campbell 1976, Henriques 1968). While the white population was diminishing, and while the planter class was experiencing failure, members of the brown class were acquiring wealth and education, and becoming increasingly visible. By the beginning of the nineteenth century they had become particularly assertive in their demands for the removal of restrictions on their progress (Campbell 1976, Henriques 1968). In large part as a result of the flight of whites from the island, obstacles to brown advancement were further relaxed.

During this period, browns increasingly achieved additional political mobility. By the 1860s the Speaker of the House, the Attorney General, and the Chairman of the Quarter Sessions were all brown men. Moreover, browns had by then become a strong faction in the Assembly - a fact that enabled them to influence its activities and decisions. Browns also experienced economic progress as well, expanding their influence in the area of business (Heuman 1976, Lowenthal 1971). For example, browns were increasingly able to import food supplies to meet the needs of a rapidly diverse middleclass, leaving behind their dependence on the declining white population (Heuman 1976). By 1838 trade in the island was being passed on to brown merchants. Brown men were 
also able to move into positions that had formerly been restricted to whites, becoming bookkeepers, tradesmen and even overseers (Heuman 1976).

Campbell (1976) illustrates the rising fortunes of brown Jamaicans through the person of George William Gordon. Today one of Jamaica's national heroes, Gordon was the illegitimate son of a white planter and a slave mother. Though apparently neglected by his father, Gordon taught himself to read, write and "keep accounts" (bookkeeping) and soon earned enough to purchase his freedom and that of his mother and sisters. By his twenty-first birthday he was a successful merchant and businessman. His story of increasing prosperity at the same time that his father was losing a number of estates reflected a pattern in which many white planters were experiencing economic ruin while non-whites were enjoying economic progress. So successful was Gordon that he was able to rescue one of his father's failing plantations and return it to him (Campbell 1976).

During this period blacks increasingly joined browns in positions of relative prestige as educational opportunities expanded, and as opportunities for suffrage became available to non-whites (Bryan 1991, Campbell 1976, Lowenthal 1971). Mobility among blacks was facilitated by the presence of ameliorative conditions, an example of which was the provision of primary (elementary) education by the Church. Primary schools had been established mainly for the children of lower class ex-slaves. Members of the black middle-farming sector (owners of small and medium farms) eager to provide their offspring with elementary education were, however, their principal supporters. In addition to providing their children with basic numerical and literacy skills, primary schools created opportunities for teaching positions and thus a means by which black middle-farmers were able to escape manual labor (Bryan 1991, Lowenthal 1971). By the 
1880s, in addition to black landowners, teachers and artisans, there were increasing numbers of black civil servants, police constables, legislators, judges, and doctors (Bryan 1991, Lowenthal 1971).

Most middle-class blacks were, however, comfortable with colonial rule and oriented toward Britain, British education, and British culture (Nettleford 1973). For this reason they were dubbed "Afro-Saxons" - meaning that they were "black men with white minds" (Lowenthal 1971: 372). Almost 200 years of British colonial rule had resulted in a tendency among Jamaicans to hold what was British (read, white) as superior. Regardless of color, it was at that time essential to adopt British cultural norms in order to attain and maintain status. Internalization of these norms by the black-middle class thus symbolically maintained a color hierarchy that held "white" over "black." Therefore, although themselves members of the black community, they did little to alleviate the status and living conditions of the black masses. Their support of British colonial rule fostered, in turn, a degree of comfort with the internal system of stratification. Few sought to challenge the hegemonic system based on color for to do so would likely result in loss of their hard-earned respectability (Bryan 1991).

The softening and then blurring of the boundaries drawn by color occasioned by emancipation and subsequent decline of the planter class, facilitated the consolidation of brown intermediate status, as well as some black social mobility. The English-oriented ideals of members of the black-middle class however, rendered them useless as far as helping to weaken barriers for lower class blacks. During this period there was yet another important development that affected demography and that blurred the boundaries 
even more by complicating the color hierarchy - the recruitment of East Indians and Chinese laborers and arrival of Jewish and Lebanese immigrants.

Complicating the Color Hierarchy: East Indians, Chinese, "Syrian" Immigrants

The recruitment of Chinese and Indian labor in the latter half of the $19^{\text {th }}$ century, and the presence of other ethnic groups such as Jews and other Middle-Easterners including Lebanese, and Palestinians (commonly known as "Syrians") created a more complicated racial and ethnic tapestry, a fact that further transformed notions of color in Jamaica (Alleyne 2002, Johnson 2005, Thomas 2004). Up to this point, except for a very small population of Jews, Jamaica had been primarily white and black (browns were both white and black). The arrival of these new groups complicated and broadened the color spectrum.

Chinese and Indians were imported to alleviate the labor shortage that plagued plantations after ex-slaves fled plantations. Jews, however, had been on the island since the Spanish colonial period (1494 to 1655). Initially imported as indentured servants to help establish the sugar industry, Jews rapidly moved away from plantations into commerce and evolved into an influential and prosperous group of merchants (Johnson 2005). Palestinians and Lebanese immigration began in the last 20 years of the $19^{\text {th }}$ century. Unlike the other immigrant groups, they did not arrive as indentured servants, but were fleeing political and religious discrimination. Following the example of more established Jews, these latter groups joined the merchant class, beginning by peddling wares (Sherlock and Bennett 1998).

The new minority groups experienced a great deal of boundary-work at the hands of whites and other Jamaicans. As non-English speaking and non-Christian groups, 
Chinese and Indians were often treated with contempt and discrimination (Johnson 2005, Sherlock and Bennett 1998). Indians, as a group, have traditionally been held in low esteem by blacks, who refer to them as "coolies" (meaning, laborers) because of their poverty and long association with the soil (Sherlock and Bennett 1998). During the immigration period no thought was given by the government to cultural accommodation and as non-Christian religions were prohibited, Indians had to meet in an ad hoc manner and wherever possible for religious activities. Additionally, the government did not recognize marriages that were not performed in Christian ceremonies; therefore Indians felt obliged to hold Christian weddings in addition to their traditional ceremonies (Sherlock and Bennett 1998). Although Indians continued to endure some social stigma as a result of their longer association with the soil through indentured labor (they remained on plantations longer than other groups) there has also been considerable social mobility of some Indians through petty commerce (Stone 1991).

Chinese immigrants also suffered discrimination but did not remain in agricultural labor for very long (Alleyne 2002, Sherlock 1998). As soon as the terms of their contracts ended they left the plantations and, using stipends awarded in lieu of repatriation to China, established business enterprises including restaurants, supermarkets, laundries and wholesale grocery trade (Brodber 1989, Johnson 2005, Sherlock and Bennett 1998). Therefore, they enjoyed rapid socio-economic mobility so that today Chinese largely belong to the middle and upper classes. Their economic success, however, evoked resentment from both whites who wanted to protect their monopoly over Jamaica's economic resources and poor urban blacks. Chinese found themselves bounded by government restrictions on further migration as well as on their commercial activities on 
the island. Black resentment culminated in outbreaks of violence in the first two decades of the $20^{\text {th }}$ century. Such boundary-work on the part of government, the white elite, and black and brown Jamaicans, provoked counter-boundary-work by Chinese. They largely separated themselves from others. In response to official and unofficial discrimination, Chinese created their own means of support through mutual benefit associations. In this way, Chinese Jamaicans have been able to develop a distinct community (Brodber 1989).

The presence and experiences of these ethnic groups have had far reaching effects on conceptions of color in Jamaica. Their relatively rapid social mobility placed them eventually within the middle and upper strata of the society. As non-African groups their relative success seemed to support notions of black inferiority. That is, they helped perpetuate ideas equating dark skin complexion with low social status. Moreover, "they established colour prejudice in the society, a variant of racism, ready to assist it in defining and to assume its role in assigning social status when the pure Europeans left the island" (Brodber 1989: 56). In other words, color, (more so than just racial) prejudice which had already emerged through the presence of browns, intensified as a result of the presence of these new groups. In the process the political and economic power of nonAfrican groups were consolidated and expanded, and color joined race prejudice in pinning dark-skinned "Jamaicans into their place at the bottom of the social hierarchy" (Brodber 1989: 56).

Another important impact of the presence of these ethnic minority groups is related to considerable mixture between them and black-white browns. Such intermixture has served to broaden the color spectrum on the island. Chinese have intermixed with blacks in higher numbers than other racial groups in Jamaica. As early 
as 1943 the census counted virtually as many mixed as "pure" Chinese (Alleyne 2002).

During the early years of the twentieth century there was also considerable mixing between Jews and browns as well as between Indians and blacks (Broom 1954, Nettleford 1998). Much of the early intermixing is attributable to a shortage of women, especially among Chinese and Indians. This fact contributed to an expanding mixed race community and to the social construction of color in Jamaica in that among the effects of such large-scale intermixture has been an expanded tendency among Jamaicans to conceive of race as a color continuum (Vickerman 2001).

During this entire period blacks achieved only minimal social mobility. Most blacks, rural and urban, were not only poor but were enduring unbearable living conditions (Brodber 1989, Charles 2010, Thomas 2004). Between 1838 when the apprenticeship system ended and 1938 most blacks were small peasant farmers, or unskilled laborers with wages less than subsistence levels. By the early $20^{\text {th }}$ century, jobs for those whose livelihoods were tied to plantations became scarce as estates failed; and those who found jobs continued to suffer low wages (Stone 1991). The deplorable conditions with which they had to contend were the primary reason behind blacks' resentment of ethnic minorities expressed in outbreaks of violence against these groups at the turn of the $20^{\text {th }}$ century. Rising discontent culminated in a number of labor riots across the island in the 1930s (Sherlock and Bennett 1998, Stone 1991).

In sum, despite some blurring of boundaries permitting social mobility among browns and a small number of blacks, the three sections of Jamaican society - white, brown (now including ethnic minorities), and black - remained intact. In the process "color" joined "race" in establishing social locations of Jamaicans. Race was of course 
still drawing bright boundaries since browns despite their success were still being bounded by whites. Browns and now other immigrant groups, moreover, found ways to draw boundaries around themselves. Furthermore, since middle-class blacks developed English-oriented norms they were no help for poor urban and rural blacks. The situation threatened to become tense as the black masses increasingly linked their race with their relative poverty.

Nevertheless, during this period, social boundaries drawn by color were definitely blurred, permitting political and economic mobility especially for browns. The intermediate position of this group is thus consolidated by the end of the $19^{\text {th }}$ century. Beginning in the late $19^{\text {th }}$ century and intensifying in the early $20^{\text {th }}$ century brown men, who by then possessed tremendous political power, took steps to break away from British colonial control. In the process they disseminated a new ideology of race and color, which finds itself in competition with notions of blackness.

\section{Creole Multiracialism Versus Black Nationalism}

While the post-Emancipation developments described above were reinforcing the importance of color in Jamaica, the island witnessed the development of a new ideology that emphasized Jamaican nationhood. This new ideology of nationalism - a Creole multiracial nationalism - came to dominate Jamaican politics by the time of independence. This new ideology had its roots in "late nineteenth century perceptions of Africa, in the history of consistent and extensive migration and in the emphasis on the part of (black and brown) middle-class mobilizers upon cultural modernization and progress" (Thomas 2004: 30). Creole multiracialism sought to combat the ideology that 
elevated British culture. British-oriented ideology had been reinforced by Crown Colony government (by which the country was ruled directly by the Crown through British governor and his deputies) which had been established in Jamaica in 1865. It was just this ideology that Creole multiracialism sought to combat. The idea was to obliterate Jamaicans' long-held orientation toward England and develop an identity that was specifically "Jamaican." The first half of the $20^{\text {th }}$ century saw the creation of various institutions and programs designed to foster the development of approved indigenous cultural art forms. That is, only select cultural art forms, that were deemed refined enough to impress the British government, were chosen for these projects. The goal was to demonstrate to the British Crown not only that the country was mature and ready for independence, but that it was also culturally distinct from Britain. As various forms of cultural expressions that were created in the "Creole" context, they demonstrated that Jamaicans were developing their own national identity. Seeking to minimize the importance of race in Jamaica, to, in fact, present the image of a society that was in effect "non-racial," the ideology also emphasized the multiracial nature of the island's population (Nettleford 1999, Thomas 2004, Vickerman 1999). The latter goal became increasingly important given the fact that the society was still very much stratified along lines of race and color. That is, given existing social stratification based on race and color, Creole multiracial ideology essentially sought to blur the symbolic (if not necessarily the social) boundaries drawn by race and color.

Scholars (Curtin 1955, Nettleford 1998, Thomas 2004, Vickerman 1999) attribute the tendency of many contemporary Jamaicans to deny the social significance of race in Jamaica to this non-racialist doctrine. From the 1930s onward, political leaders such as 
Alexander Bustamente and Norman Washington Manley who were of mixed racial origin but white (European) in phenotype and therefore perceived as white, aggressively promoted the importance of social unity, and also firmly denounced social activities that they perceived as divisive - especially on racial grounds (Nettleford 1970, Richards 2002). Manley and Bustamante who later established and led the People's National Party (PNP) and the Jamaica Labor Party (JLP) respectively, continued to oppose any claims that were made in the name of race, as the country moved toward independence from British rule. Norman Manley became obsessed with Jamaica achieving nationhood. His primary concern was for Jamaicans to conceive of themselves as one people who, though bearing varied origins, were one in their "Jamaicanness" (Nettleford 1970). It was the objective of both Manley and Bustamante to make non-racialism a symbol of Jamaican character. They declared that Jamaica and the West Indies were "made up of peoples drawn from all over the world, predominantly Negro or of mixed blood, but also with large numbers of others, and nowhere in the world has more progress been made in developing a non-racial society in which colour is not psychologically significant" (Nettleford 1998: 23-24). Similarly, in the previous year, Bustamente who was then Leader of the Opposition denounced the appeal for militancy among black Jamaicans made by the widow of Marcus Garvey, arguing that such "racialism" was a "menace to our future" which for Bustamante meant destroying the foundation of nationhood (Nettleford 1998).

Efforts at nation-building in various colonial societies have shaped constructions of race and ethnicity (Appelbaum et al 2003, Foote 2006, Johnson 2005, Spickard 2005, Stone 1973). In many colonial societies, concerns regarding nation-building centered on 
the development within a particular collectivity of a shared sense of identity and the desire for self-government (autonomy) (Spickard 2005). In Jamaica, as has been shown, the light-skinned men who led the country into independence from Britain in 1962 emphasized pride in nation and deemphasized the importance of "race" through the motto "Out of many, one people" as the country neared its independence (Johnson 2005, Stone 1973, Vickerman 1999). They frequently boasted that the country had rid itself of all racial discrimination and in the rhetoric of those light-skinned men the "black man" became the "small man" (Nettleford 1970). Their de-emphasis of race was an intentional attempt to minimize the possibility of social unrest as these light-skinned leaders were very aware of the persistent racial disparities that plagued the country. As Stone (1973: 100) put it, "The official ideology of multiracialism should therefore be seen as an attempt to neutralize the hostility of the black masses towards a situation in which whites and other racial minorities dominate and control the local economy."

Since the late nineteenth century, however, a competing ideology that embraced blackness, had also begun to emerge. Such an ideology would not have been necessary had the island been devoid of racism. Black activists led movements of various kinds designed to combat racist notions that elevated whiteness and denigrated blackness and to develop among blacks a sense of pride in their race (Thomas 2004). They also sprang from efforts to alleviate the poor living conditions which many blacks suffered. Examples of such efforts include Marcus Garvey's nationalist and repatriation to Africa scheme, and religious movements such as Rastafarianism and Bedwardism (Austin-Broos 1994, Thomas 2004). 
Garvey's first experience with race prejudice occurred during his childhood when his white female playmate was forbidden from further association with Garvey because he was black (Hutton and Murrell 1998). But his travels throughout Central America, Europe and the United States, during which he was exposed to the terrible conditions under which blacks worked, are responsible for his radical worldview on the plight of blacks in the New World (Austin-Broos 1994, Hutton and Murrell 1998). Garvey was committed to elevating the status of blacks across the world. And he was convinced that in order to achieve that goal, blacks needed to develop pride in their "race." As such he was a strong advocate of black ethnic pride and racial exclusiveness. Among his goals was the repatriation of New World blacks to Liberia in order to establish an independent black nation. Garvey therefore opposed the state sponsored ideology downplaying race, and argued that in ignoring race Jamaican blacks were doing themselves a disservice. He was unapologetic in his appeal for racialism among Jamaican blacks. In a 1916 letter written to Major R. Moton, of the Tuskegee Institute Garvey wrote:

The black people have had seventy-eight years of emancipation but all during that time they have never produced a leader of their own, hence they have never been led to think racially but in common with the destinies of the other people with whom they mix as fellow citizens. After emancipation the Negro was unable to cope intellectually with his master and perforce he had to learn at the knees of his emancipator.

He has, therefore, grown with his master's ideal and up to today you will find the Jamaican Negro unable to think apart from the customs and ideals of his old slave masters. Unlike the American Negro, the Jamaican never 
thought of race ideals much to his detriment, as instead of progressing generally, he has become a serf in the bulk and a gentleman in the few. Racial ideals do no people harm, therefore, the Jamaica Negro has done himself a harm in not thinking on racial ideals with the scattered Negroes of other climes (Lowenthal 1973: 4-5).

Garvey's emphasis on race as inextricable to black identity, though popular among the black underclass in the United States, held limited appeal in Jamaica (Brown 1974, Sherlock and Bennett 1998, Thomas 2004). In part this was due to lack of support from the country's leaders whose de-emphasis of race conflicted with Garvey's focus on racial thinking and racial exclusiveness. It was also due to the fact that his repatriation scheme was not attractive to most black Jamaicans. Nevertheless, the followers he did have in Jamaica were attracted to his efforts to elevate the status of poor blacks by calling for protection of labor through the establishment of a minimum wage and land reform (Thomas 2004).

Rastafarianism and Bedwardism were Black Nationalist projects that built allegiance through both religion and race. Influenced by Garvey's philosophy they both rejected the Christianity of white colonizers. Rastafarians generally held that Africa (Ethiopia) was their home and Haile Selassie, Ethiopia's emperor, their God (Brown 1974, Hutton and Murrell 1998, Murrell 1998, Thomas 2004). The ways of the white man were thought to be evil, especially for blacks (Murrell 1998). Rastas favored African repatriation as they considered Ethiopia to be "heaven" and Jamaica, the land in which they were held in subjugation, "hell" (Brown 1974). Through his revival movement, the Native Baptist Free Church, Alexander Bedward preached about the oppression of blacks 
by white colonizers and criticized the Anglican Church. Bedward challenged the incorporation in the Christian religion of ideas linking "black" with "evil" opposing even prayers in which black Jamaicans asked God to wash them "white as snow" (Chevannes 1998: 57). He declared himself the deliverer of black people; for him, deliverance was spiritual (Thomas 2004).

The importance of the above-mentioned movements to Jamaican race ideology lies in their common appeal to race in spite of politicians' appeals for emphasis on a unified national identity rather than on race (Thomas 2004, Vickerman 1999). They point to deeply felt concerns, even desperation among black Jamaicans for radical change in their social status. They demonstrate a desire to combat long-held notions of black inferiority. Most importantly they indicate that, at least in the eyes of adherents to these ideologies, race was still drawing some boundaries for black Jamaicans. Creole multiracialism and the state sponsored ideology downplaying race, seemed to have as its goal the dismantling of symbolic boundaries drawn by race - at least in the minds of dispossessed blacks. Black Nationalist movements on the other hand, re-erected those boundaries in their efforts to emphasize racialism and pride in blackness. Theirs was, however, a different type of boundary-work as their specific goal in drawing lines around themselves, was to create a collectivity that could smash existing boundaries to their social mobility.

Despite the efforts of Garvey et al. to encourage racial thinking governmentsponsored ideology downplaying the importance of race has impacted Jamaicans' attitudes toward race. While Jamaica is by no means entirely non-racial, Jamaicans' discouragement of racial discourse, as expressed in the motto, "Out of many, one 
people," has had the effect of muting race consciousness in sectors of post-Independence Jamaican society (Curtin 1955, Vickerman 1999). Thus although racial concerns are still present, particularly among poor blacks, a tendency to deny that race is important in Jamaica may be found in many Jamaicans, including blacks. And to a great degree the tensions between state-sponsored non-racialism black Nationalist sentiment explains the complexities and contradictions that characterize understandings of race in Jamaica.

An example of the impact of the state-sponsored ideology on Jamaicans attitudes toward race may be found in the absence of overt racial activism in the Jamaican trade union movement. Glen Richards (2002) in his analysis of trade unions in Jamaica argues that unlike most other British West Indian territories, Jamaica's labor unions were characterized by an "absence of pronounced race consciousness"(Richards 2002: 340). The arguments and activities of trade unions in Trinidad and St. Vincent, in contrast, were carried out along strong racial overtones. Despite the efforts and ideas of Marcus Garvey, racial overtones were missing from Jamaica's unions. Richards (2002) explains this missing racial element by focusing on the Jamaican trade union leadership. The earliest attempts at organized labor occurred in 1898 - fifty years after emancipation and were conducted by artisans who themselves were black. These attempts were short lived, largely due to the scattered nature of workers as well as to the lack of a common unifying cause (Richards 2002). Early in the twentieth century, brown leadership had completely taken over. It was primarily due to the dominance of the brown middle class that race was muted in the labor organizations:

Brown middle-class ascendancy over the Jamaican labour movement helped to firmly entrench, within the black working population, the 
middle-class belief in the mutual interests of the employing and employed classes, and ensured that the divisive issue of race did not surface or was easily contained. Organized labour in Jamaica consequently became an instrument for securing the political leadership of the brown middle class, by successfully suppressing or subverting any hint of racial or colour consciousness within the ranks of the labour force (Richards 2002: 349). The rise of brown men to political leadership in the twentieth century is, therefore, largely the result of their involvement in labor unions. This is certainly true of both Norman Manley and Alexander Bustamante both of whom spearheaded the labor union movement of the 1930s. They used their leadership of labor unions to convince their largely black working class members that employers and employees had mutual interests, hoping, in so doing, to subdue racial discontent, and prevent disturbances motivated by race.

It is important to note, however, that workers who joined trade unions did in fact hold racial concerns, even if there were no outbreaks or divisions based on race. The very reasons for the labor riots which led to the establishment of these unions were racial disparities in employment, and especially wages that discriminated against blacks. Black workers across the island staged labor riots during the 1930s in protestation of their low wages. What Richards alludes to then is that unlike trade unions in other parts of the West Indies, racial overtones were not encouraged by union leaders. 


\section{Persistence of a Color Hierarchy}

While there was considerable social mobility among blacks, the number was relatively small and likely restricted to descendants of free blacks. The vast majority of black ex-slaves remained at the bottom of the social hierarchy. In part, their place there was reinforced by boundary-work on the part of browns who continued to find ways to dissociate themselves from blacks even those who are members of the middle-class. Of course such boundary-work had the specific purpose of avoiding the stigma associated with African ancestry in a society that still held Britain and whiteness as the ideal. After emancipation, browns continued to demonstrate hostility toward blacks in various ways. Politically, browns declined to collaborate with blacks - at times even opposing black presence in the Assembly (Heuman 1976). Browns who had been enslaved refused to work with blacks in the field, at times as going as far as to refuse even to shake hands with blacks. In fact, less affluent browns, seemed particularly anxious to avoid association with blacks.

In the 130-year span between emancipation and independence, Jamaican society witnessed many developments that complicated the color hierarchy that had been constructed under slavery. For much of this period the hierarchy remained virtually intact: black ex-slaves had formed a peasant class and remained at the bottom of the hierarchy; a small white population maintained economic and political domination; and the 1830 removal of restrictions to brown mobility created the opportunity for the consolidation of the brown class' influential position in the middle. Yet with the significant social, political and economic gains achieved by the brown group and the emergence of a small but visible educated black middle-class, the relationship between 
color and social status was already becoming quite flexible by the middle of the twentieth century. Immigration of individuals from India, China, and the Middle East only further blurred previous social categories.

Race, though still drawing boundaries between whites and blacks, and between whites and browns, is overshadowed by color, which takes over as the primary means of distinctiveness. Gradations of skin complexion, social status, English-oriented ideals and behavior, continued during this period as dominant determinants of social location. Brown leadership helps to elevate the importance of light skin complexion. What begins to emerge then is a much more fluid situation in which the boundaries drawn by color are at first bright, then increasingly with these different criteria determining social status, blurry. The next section discusses the impact of additional challenges to bright boundaries.

Section 3 - Boundary-Shifting: Race, Color and Social Status after Independence (1962 to present)

Boundary-Blurring: Race, Color, and Social Location

After political independence from Britain in 1962 the white population experienced further demographic declines primarily as a result of the repatriation of many in their ranks, especially those in military and civil service, to Britain (Headley 1984). According to the 1970 census count, whites comprised a mere .66 percent of the entire population, a drop from 0.77 in the 1960 census. By 2001 the white population had fallen to 0.18 of the population. Consistent with previous periods in Jamaican history when the 
white population declined markedly, the vacuum in social power was filled by browns (now identified for census purposes as "mixed" but still popularly known as "browns.") They advanced into the upper-class - though not into the 'elite' which was still held primarily by whites (Stone 1991, Thomas 2004).

Some scholars, notably M.G. Smith (1974) and Fernando Henriques (1968), have argued that in the years immediately following independence the tripartite color hierarchy remained more or less intact. While political power had been handed over to members of the brown and black middle-classes, they argue, economic power was still largely restricted to upper-class browns and to the remaining members of the small white elite (Nettleford 1970). Moreover, while a majority of blacks who shortly after independence comprised 78.1 percent of the total population still belonged to the lower class, most browns continued to occupy the middle-class as well (Gordon 1991, Henriques 1968, Stone 1991).

$\underline{\text { Blacks and Social Mobility after Independence }}$

Persistent black activism in the form of Black Power in the 1960s, (that is before and after independence) demonstrated ongoing concerns about the condition of the largest sector of the population. Black Power advocates accused the country's leaders of having failed to deliver their promises to liberate the masses (Nettleford 1970). Adherents to the Jamaican Black Power movement were varied and ranged from black intellectuals to brown middle-class individuals who demonstrated a commitment to the black masses (Nettleford 1970). In general, supporters objected to foreign domination of Jamaica's natural resources (such as bauxite), to their continued dominance of the sugar industry, and to the fact that the nation's wealth was still largely in the hands of the minority - 
upper and middle-class whites, browns, Chinese and Syrians or Jews (who by then were generally lumped together with whites) (Thomas 2004). Rastafari also continued to denounce persistent white bias and to struggle for elevation of blackness in the 1960s and 1970s (Murrell 1998, Nettleford 1973). These activities demonstrated persistent concerns for the plight of blacks.

In early years of Michael Manley's government through the People's National Party (PNP) from1972 to 1980 it seemed there was hope for change in the status of poor blacks (Thomas 2004). Manley aimed to establish a strong state sector and see to the transfer of both economic and political power from the traditional elite to the new rising elite. His policies included the nationalization of key sectors of Jamaica's economy and the establishment of a number of social programs designed to foster social and economic development through educational and community development programs. Manley's government aimed to elevate "blackness" while at the same time providing for "tangible" benefits through social advancement (Thomas 2004). Manley's policies were, however, doomed to failure. His declaration of "democratic socialism" at the beginning of his second term in 1976 and his increasing connections with Cuba caused alarm among the nation's white and brown elite. Several elite families fled the country taking their money with them. To take a stand against communism, private sector organizations and sections of the religious establishment also abandoned the party for the opposition Jamaica Labor Party. The PNP therefore lost much of its economic support and Manley was unable to finance his social programs (Thomas 2004).

The preceding developments had a two-fold result for Jamaicans. Rapid and widespread flight of elite families led to the sudden creation of opportunities for 
economic advancement for some black Jamaicans (Kaufman 1985, Thomas 2004). Middle-class blacks who, having previously taken advantage of expanding educational opportunities, already held white-collar and professional positions in the public sector abandoned the latter and sought opportunities in the private sector. Therefore, despite severe national economic decline, blacks throughout the 1970s comprised forty to fifty percent of the top middle-level private sector positions, signaling significant changes in the racial make-up of the division of labor (Kaufman 1985, Thomas 2004). In this way, middle-class blacks experienced greater economic success.

For the very poor black masses, however, not much had changed. Cultural development and elevation of blackness meant very little in the face of persistent poverty. Manley's failure when combined with the historical relegation by plantation society of blacks to the lowest stratum of Jamaican society led members of the black urban and rural poor to increasingly link their poverty to their blackness (Thomas 2004).

\section{Brown, Mixed, and Ethnic Minorities}

Meanwhile, further brown economic advancement after independence was fostered by structural factors including continued flight of the white elite (especially during the Manley regime) and the expansion of tourism, export, and manufacturing industries as the plantation economy declined (Stone 1991). The fact that browns had historically enjoyed privileges such as access to higher education and property also provided a foundation that facilitated their continued privileged position (Stone 1991). That is, the fact that browns were already generally located in the intermediate stratum of Jamaica's social structure gave them a head-start as far as further social advancement. 
The contemporary mixed group has been transformed by the incorporation into its ranks of ethnic minorities such Chinese, Jews, Lebanese, and Indians. Chinese, Jews and Lebanese used their experience with petty commerce to gain entry into large scale manufacturing and tourism services, which increasingly became central to Jamaica's economy with the decline of plantations. Intermarriage among these groups has facilitated the consolidation of the control of capital among members of this intermediate class. Stone (1991) argues the choice of browns and ethnic minority groups to marry among themselves was a deliberate strategy for ensuring the maintenance of their higher social status. By the 1970s and 1980s ethnic minorities owned most of Jamaica's large business enterprises. In this way browns and ethnic minorities were engaging in a type of "opportunity hoarding," (that is, in restricting access of other group to those resources) and in so doing reinforced their monopoly of the business sector (Massey 2007). Thus, despite significant social mobility among blacks, the intermediary group comprised of traditional browns and ethnic minorities has emerged as powerful capitalist class based in urban areas (Gordon 1991, Stone 1991).

\section{Color as Symbolic and Social Boundary}

The boundaries drawn by color that have traditionally determined social locations have shifted for blacks and browns. Color is no longer the only determinant of social status. Yet the expansion of the middle stratum into a powerful capitalist class has at the same time reinforced the symbolic link between color and class, since it has strengthened notions that link lighter skin and non-African phenotypes with middle-and-upper class status. As such color functions primarily as a powerful symbolic boundary. 
The role of color as a symbolic boundary is demonstrated by the continued tendency among many contemporary Jamaicans to idealize "light skin" (fair complexions) and European or simply non-African phenotype (Alexander 1977, AustinBroos 1994, Miller 2001, Nettleford 1998, Thomas 2004). And the higher status that is accorded to light skin and non-black phenotype is reflected in popularly held notions about female beauty. Many Jamaicans tend to denigrate non-European phenotypes, especially dark skin and "bad" (kinky) hair - particularly in women. European features, and "good" (straight or curly and perhaps, long hair) are considered to be more attractive (Alexander 1977, Miller 2001, Mohammed 2000). Alexander (1977) cites a female respondent who defined "better looking" thus: "Straighter nose. You know when people say good looking they're always talking about the nose" (1977:418). Errol Miller's study of body image among teenagers also revealed a preference for features that approximate the "Caucasian" type and dissatisfaction with "Negroid" hair and nose (Miller 2001: 307). Similar tendencies were also noted among Chinese respondents who expressed specific dissatisfaction with the "slanted" eyes typically associated with people of Chinese descent.

Racial mixtures are also idealized, particularly among middle-class Jamaicans (Nettleford 1973). Such idealization is, in part, due to the fact that non-African features, especially light skin, are believed to grant access to social mobility (Alexander 1977, Alleyne 2002, Miller 2001). The phenomenon of skin bleaching reflects this belief (Alleyne 2002, Charles 2003, 2009, Taylor 2006). Skin bleaching, occurs globally and involves the application of skin lightening creams, or homemade lotions. Individuals who bleach their skin generally argue that lighter skin will afford them higher social status, 
and women argue that lighter skin makes them more attractive (Charles 2009). In fact, a recent study conducted among 58 high school students and young adults found that a majority of bleachers give beauty-related reasons for bleaching their skin Charles (2009). The study demonstrated the pervasiveness of norms holding lighter complexions as superior to darker ones that evolved under slavery and persist today. Thus “...skin bleachers alter the physical self after equating light skin with beauty, attractiveness, popularity, social acceptance, high status, and prestige, which they elevate over its opposite dark skin and equate with ugliness, coarseness, low social status, and low prestige and social stigma"(Charles 2009: 166). One woman who bleached her skin, Tamara, insisted that "white people get jobs easier, earn the highest salaries and attract handsome wealthy men" (Andrew 2002).

The symbolic value of light skin is also reflected in a prevailing preference for light-skinned women in dating relationships and in the choice of a life partner (Alexander 1977, Campbell 1976, Lowenthal 1971, Mohammed 2000). This preference has its roots in slavery, where black and brown women welcomed the advances of white men because they believed such liaisons might improve if not their own status, perhaps that of their light-skinned progeny (Campbell 1976). For similar reasons, many black and brown women, both slave and free, preferred concubinage with a white man over marriage or cohabitation with a black man. But the preference for light-skinned women is also linked to a larger process of sexualization through which the racially mixed woman was portrayed as particularly exotic, desirable, and hypersexual (Mohammed 2000, Root 1997). 
The preference for the "browning" or light-skinned, mixed-race woman has persisted in contemporary times (Alexander 1977, Alleyne 2002, Lowenthal 1971, Mohammed 2000). Such preference is, for some, based on the belief that a mate with lighter skin will "improve" an individual's progeny in terms of phenotype and therefore increase chances for social mobility (Alleyne 2002). The persistence of such ideals is illustrated in the words of a dancehall song written and produced in the 1990s by one of Jamaica's most popular dancehall artists, Buju Banton, "Mi love mi car, mi love mi bike, mi love mi money and ting. But most of all, mi love mi browning” (Mohammed 2000). The term "browning" emerged in Jamaica in the 1980s and generally refers to the mixedrace or light-skinned woman. Rooted in notions linking status to light complexions, the term also connotes privilege as explained below:

The browning in Jamaica comprises a recognizable combination of black and white (and/or other ethnic groups such as Chinese or Jews). More apposite, the browning in Jamaica also represents a class of people, the post-colonial inheritors of privilege and status passed on by the white upper class. Blacks are still perceived to occupy the lowest rung of the class pyramid in Jamaica, although there have been considerable changes since the nineteenth century. It is no longer simple to pin down class and status by colour. Nonetheless, the legacies of the colonial past are still evident, and the clear skinned or fair skinned, straight ('tall') haired woman still figures as a desirable catch. (Mohammed 2000: 35)

Notions linking feminine beauty to light skin are also reflected in Jamaica's beauty contests. Barnes (1997) shows how beauty contests in Jamaica have historically 
featured women who were white or who looked white. Public outcry, especially in the 1970s and 1980s, against the practice resulted in a reduction of white-looking finalists and an increase in brown, racially-mixed, and especially Indian women, who by virtue of their long straight hair and non-African features are, at least in terms of beauty, ranked higher than dark-skinned blacks on the color hierarchy (Mohammed 2002, Nettleford 1973).

Thus the perception held by skin bleachers that light skin will enrich their lives socially reflects notions formed in colonial times that continue to plague Jamaican society. Since most white and light-skinned Jamaicans still occupy the upper and middle classes the persistence of these notions is not surprising. As Nettleford (1998: 24-25) writes, "In the minds of many Jamaicans, it is still a poor-black, a middle-class and privileged brown man, and a rich or wealthy white man." For many Jamaicans, then, color still functions as a symbolic boundary that assigns social location. That is, many Jamaicans continue to make assumptions about social status based on skin color. And the fact that the persistent presence of racially mixed and light-skinned Jamaicans in the upper echelons of the society suggests to some Jamaicans, that color still functions also as a social boundary.

Idealization of mixed blood, denigration of black phenotype, and preference for light-skinned or racially mixed women are all examples of how color functions as a symbolic boundary in contemporary Jamaica. Black and brown social mobility especially in the $20^{\text {th }}$ century suggests that race and to a great degree, color have been decoupled from class. Thus despite the assertions of skin bleachers, it is unlikely that an individual may be denied employment solely based on race or color. Yet the practice of skin 
bleaching and the reasons provided for such are a reflection of how color still draws both symbolic and social boundaries. They are symbolic boundaries in that they exist in the imagination and discourse of contemporary Jamaicans including urban skin bleachers and the middle-class Jamaicans (Alexander 2001, Miller 2001). And where it comes to intimate relationships they are transformed into social boundaries. Thus while color itself no longer functions as a bright boundary that determines social status, and while individuals may thus interact with others of varying races and hues, boundaries are often redrawn for Jamaicans in intimate relationships and especially in marriages (Thomas 2004).

Since Independence in 1962, the boundaries drawn by race and color have shifted. Such boundary-shifting has permitted admission of browns and blacks into the upper and middle-class respectively. The remaining small white elite, virtually invisible to large sectors of the black population, though largely controlling economic resources in the country, has removed itself from symbolic control of the island. Race and color have thus ceased to be the primary determinants of social location; that is, race and class have been decoupled. But as has been shown, this is true only to a degree, since the fact that browns, ethnic minorities and whites still largely control economic sector, and since most blacks are still poor, there is still a tendency among the poor black masses still link color and with status. Moreover, color continues to draws symbolic and social boundaries in ideas about feminine beauty, beauty pageants, and choices for marital partners. One may argue, therefore, that a color hierarchy remains in effect, but only to a certain degree.

What is important is that the boundaries currently drawn by color are blurry, rather than bright. A great deal of boundary-shifting especially after independence has 
resulted in a decoupling of race and class. Moreover color appears to be drawing primarily symbolic boundaries, perhaps drawing social boundaries only in the most intimate spheres (marriage and the joining of families).

\section{Chapter Conclusion}

Thus unlike the U.S. which evolved a rigid racial dichotomy, buttressed by the bright boundary of the one-drop rule, Jamaica has constructed a complex and fluid color hierarchy in which color draws boundaries that are blurry, rather than bright. As the color hierarchy is constructed during and after slavery, joins race in assigning social locations of Jamaicans. Continued weakening of the boundaries in the $20^{\text {th }}$ century permits considerable social mobility among blacks. Race and color then cease to be the primary determinants of social status, particularly as extensive intermixture among the various groups further complicates notions of color. Moreover, despite several indications of boundary-blurring as far as social mobility, color still draws both symbolic and social boundaries in notions of beauty and intimate relationships.

Jamaica has constructed a racial worldview that has been significantly more complex than the dichotomous classification derived from the "one-drop" of the U.S. though, as explained in the last chapter, the U.S. racial hierarchy is undergoing some transformations that are producing shifts in its worldview. The different construction of race in Jamaica, one that emphasizes color, grants racially mixed Jamaicans a position of relative prestige in Jamaica. There, color continues to draw boundaries, primarily in intimate relationships, and in so doing preserves browns' privileged position in the color hierarchy. Jamaica's more fluid color hierarchy, moreover, explains the absence of a onedrop rule that limits racial identifications for people with black ancestry. It is with this 
more fluid frame of reference that mixed-race Jamaicans enter the U.S., and encounter an unfamiliar and much more rigid racial system. That their discovery of the one-drop rule causes them great consternation is therefore no surprise.

In describing the construction of race and color in Jamaica, this chapter has relied on the arguments of scholars. The literature has, however, provided little opportunity for exploration of the experiences of mixed-race Jamaicans in contemporary Jamaica. Participants in this study have provided stories that fill the gap. The next chapter thus discusses their memories that participants share about their experiences with race and color in Jamaica. 


\section{CHAPTER IV}

\section{Out of Many, One People: Race and Color in Jamaica}

"I grew up thinking of Jamaica, in terms of race, as a predominantly black country. It's a very mixed culture because our motto is 'Out of many, one people.' We learned that in school. The schools that I've mostly attended have that racial mix (because Jamaicans are mixed). It seems that people assume that every Jamaican is black with dreadlocks; but that's stereotypical. The truth is that there are a lot of races there," said Karen, when I asked her to describe to me what "race" was like in Jamaica. A 26year-old graduate student who entered the U.S. shortly after graduating from high school in Jamaica, Karen had come to the U.S. in order to pursue a university degree. Shortly thereafter she became a U.S. resident. She has lived in the U.S. for nine years. During her interview, Karen told me that she had always conceptualized herself racially as "mixed" while in Jamaica. She described her father as black, and her mother, as Indian. And while she referred to her mother's ancestors as "all Indian," she described her paternal grandmother as Indian, black and Chinese - a factor that only increased her sense of being racially mixed. I asked Karen to share a story that illustrates her impressions of race in Jamaica and she shared the following, "I think it became an issue for me when I was still very young - because my mother is Indian, and my father is black. She migrated to the U.S. when I was only six years old. So I grew up with my father. Now I specifically remember going to his work with him and someone had said to him, 'Oh that's such a beautiful child. Whose is it?' My father was immediately offended. And as I look back I realize that the reason he was offended is because the person was suggesting that a black person could not have a child like this." 
Karen also told me of encounters with her mother during which her mother made disparaging remarks about blacks. She also remembered, in particular, her mother's complaints about needing to straighten Karen's hair because "black hair" was so difficult to handle, "My mother would say, 'This is too difficult for me to manage. I don't know what to do with this type of hair. I'm not used to it. It's 'nappy' 'knotted' black hair. So let me straighten it. So she straightened my hair! To this day she still says those things, “That's black hair. It's impossible to comb it.' Or 'straighter Indian hair is better than you know wavy hair."' Given her black ancestry, these experiences and comments were disturbing for Karen.

Yet not all of Karen's memories were of unpleasant experiences. Karen also remembers that as a light-skinned, mixed-race female she had enjoyed a great deal of privilege in Jamaica, "Now when I was growing up [in Jamaica] people thought they were more elite if they were mixed as opposed to black. So even in Jamaica prejudice occurred between racially mixed people and blacks. So I guess while I was there, because I'm mixed...I had the sense that I was more elite, and that people looked at me differently. And even as I got older most men (not so much women) would say, "Oh yes she's mixed!" or sometimes, "She's a browning!" or something like that. So it [race] was there. There were terms that they would separate you from everybody else in the country."

Thus, in addition to learning during her childhood that she was considered especially pretty, she also recalls feeling that she belonged to an "elite" group, being viewed as "different," and having her mixed racial ancestry being commented upon, especially by men. She recalls being given preferential treatment by her teachers. She 
remembers, in particular, that students with lighter complexions were often spared the harsh criticisms that teachers wreaked out on students with darker complexions.

Karen's story provides clues to the meanings attached to being racially mixed in Jamaica and those meanings, in turn, indicate the ways in which race functions in that society. In her introductory statement, she refers to the motto "Out of many, one people" explaining that although demographically the country is primarily black, the motto demonstrates its multiracial character. That she begins with the motto, even mentioning that it is taught in schools, suggests that it holds some meaning for her. As her story progresses, it becomes clear that Karen experienced life in Jamaica not merely as a Jamaican, but as a racially mixed person. It becomes evident moreover, that being racially mixed meant something to her as well as to the Jamaicans who commented on her physical appearance. In underscoring the special meanings that being racially mixed holds in Jamaica, Karen's memories and her commentary provide clues about how social hierarchies are constructed and expressed on the island. They also provide clues about how Karen's perceptions of herself and her place in that social hierarchy were formed. And they raise questions about how those perceptions might have influenced upon her reactions to her U.S. racial experiences.

Relying on the arguments of historians and other intellectuals, the previous chapter argued that while, as in the U.S., race initially drew bright boundaries in Jamaica, different processes of boundary-blurring and boundary-shifting have led to the construction of a complicated color hierarchy. Within this hierarchy, color more so than race, now draws boundaries that are more blurry than bright. Using my interviewees' stories, this chapter discusses what mixed-race Jamaicans' experiences on the island 
reveal about constructions of, and boundaries drawn by, race and color there. Their stories correspond to the literature in that they demonstrate complex understandings of race and color. Moreover, based on their unique experiences, they provide additional clues about the various ways in which boundary-work still takes place there. That is, my participants' experiences as racially mixed Jamaicans generate data that are not thoroughly explored by the literature. Moreover, like Karen's, my interviewees' memories provide an important backdrop to their reactions to their migration experiences, and the impact of those experiences on their racial-self perceptions.

The stories that are shared here represent themes that respond to the following basic questions:

- What do participants' memories reveal about constructions of race and color in Jamaica?

- What do they reveal about where and how are boundaries drawn?

- How are boundaries expressed and socially enforced?

That is, according to participants' memories, and even as they assert that race is not terribly salient in Jamaica, how is boundary-work done in Jamaica? Exploring what racially mixed Jamaicans have experienced on the island that determined their social status, this chapter analyzes the ways in which contemporary Jamaican social status is inflected by much more than race or color. This chapter is, therefore, as much about social construction as it is about boundary-work; it is about the social construction and mutual constitution of different axes of identity that produce social status in Jamaica.

This chapter does not intend to describe race in Jamaica. To do so would require systematic data collection in Jamaica and among Jamaicans who live on the island. This 
was not part of my research methodology. However, during interviews people offered their memories of race and racial experiences in Jamaica and, in a few cases, impressions from recent visits. In this dissertation I explore the conceptualizations of race Jamaican immigrants of mixed racial ancestry hold in their heads, the impressions and memories they hold of race in Jamaica. I am aware that as migrants their memories may not be completely accurate. As migrants they may hold idealized memories of the island. Moreover their memories and how they recount them are also likely influenced by their migration experiences. Yet this is precisely what the chapter intends to reveal: the impressions they hold of race in Jamaica and how these affect how they react to the racial system they encounter in the U.S. What do these impressions tell us about participants and how they view themselves?

\section{Race Is Not Important}

Thirty-six-year-old, biracial (black/Indian) Anita frowned as she answered my question. We were seated at her dining table in her comfortable two-story townhome in Palm Beach. I had asked her to tell me as much as she could about race in Jamaica. "Race is not an issue over there in Jamaica," she asserted." We all consider ourselves as one over there. People don't worry about whether you're black or white. Jamaicans are, on the whole, friendly people. Whether you're black, whether you're white, whether you're Chinese - I think Jamaicans embrace people as, well, people! Although they will look and say, 'That is a white person or that person is Chinese.' I think they still see everyone as 'one.' They are not racists. I didn't at all see a lot of racism in Jamaica.” 
Anita's response is typical of that of my interviewees who, by and large, dismissed race as having social significance in Jamaica. That is, they told me that race had little or no impact on one's daily experiences or chances for social mobility. They asserted that the island was multiracial, admitted to the existence of different racial groups, but insisted that the groups co-existed in a situation of virtual racial harmony. Anita's quote nicely summarizes participants' comments in this regard. Her comment "we consider ourselves as one" suggests racial harmony, and while she indicates that people are aware of the existence of different racial groups and will sometimes identify individuals in racial terms, "that person is a white person or that person is a Chinese person," she insists that racial unity characterized the society. Frowning once more, she paused before responding to my request to describe her experiences with race in Jamaica: Well in Jamaica whenever people first saw me they didn't look at me as a black person. They looked at me as Indian. They would look at me and ask, "What are you? Are you Indian?" because in Jamaica it's mostly Indian and black. They also asked me where in Jamaica I was from. But growing up in Jamaica, I didn't have any bad experiences at all. People just asked me questions about my race.

Anita, who explained to me that her mother was black and her father was Indian, has very fair skin, long dark hair with large curls, and fine facial features. Her appearance evidently made her stand out among members of her rural community in south western Jamaica. Yet despite the many questions about her racial ancestry, which in themselves indicate that race holds some meaning in Jamaica, she insists that her experiences were devoid of racial tension. Anita evidently thinks of race as holding significance only if 
there is blatant hostility among racial groups. Merely asking about someone's racial ancestries does not necessarily suggest hostility. She states she did not see much racism, suggesting she either observed or experienced some. But she does not seem to think of any such experience as having been at all significant.

Twenty-six year old multiracial (black/Indian/white) Kevin shared similar opinions, arguing that, "In Jamaica there is a tendency to notice people's racial identity. But I don't think it's about discrimination or segregation. In Jamaica they referred to me as 'coolie' or 'Indian' because my father is Indian and I guess because my hair type is a little different from the African Jamaicans' hair. But Jamaica is pretty mixed. I went to school with Chinese guys, fair-skinned guys, white guys, Indians, and blacks, and there was really no segregation. No one made an issue out of whether one was Chinese or Indian. People just referred to you as what you were and it wasn't an issue.”

Kevin, like most participants, was bent on describing Jamaica as lacking in racial tensions, in spite of the existence of different racial groups. Like Anita he insisted on virtual racial harmony: "No one made an issue out of whether one was Chinese or Indian." Interestingly, he says this while at the same time pointing to racializing encounters in which Jamaicans take note of people's appearance, ask pointed questions about their non-black ancestry, and use racial terms to make distinctions, without attaching any significance to those encounters.

Responses such as those provided by Anita and Kevin indicate something about social constructions of color in Jamaica. They are reflective of a construction of color that identifies racial differences but, according to them, does so without attaching social significance that includes feelings of resentment, or hostility. I argued in the last chapter 
that color (primarily skin complexion) had taken precedence over race proper as a basis for boundary-work in Jamaica. Moreover, any boundaries currently drawn by color are blurry rather than bright, and often symbolic, rather than social. That is, people associate skin complexion with social status, locate individuals in certain categories based on these assumptions about that relationship. But allocation of and access to resources based only on color rarely, if ever, occurs now—unlike in the past. And while intermarriage among ethnic groups and brown Jamaicans ensured a degree of opportunity hoarding especially in the 1970s and 1980s, there is no evidence that doing so completely excluded blacks as a group. In sum, whereas in Jamaica during slavery race categories became the basis for social stratification, in post-slavery Jamaica social stratification along racial lines appears to have been overcome even though people still pay attention to and even rank racial categories, only renaming them as "color" not race.

My interviewees' insistence on racial harmony thus likely reflects the construction of a color hierarchy within a social context in which race does not appear to be tightly associated with either social status or social mobility. That a majority of participants denied that race is important in Jamaica was, moreover, an expected outcome given similar findings in the literature addressing race in Jamaica (Alexander 1977, Waters 1999, Vickerman 2001). Interested, however, in what might explain participants' memories of racial harmony, I carefully examined the data for clues and found two dominant explanations. In the first place, participants denied race as socially significant largely due to the influence of the motto, "Out of many, one people." Secondly, interviewees asserted that class, rather than race drew significant boundaries in Jamaica. 


\section{Out of Many, One People (No Racial Boundaries)}

I met 24-year-old Nicola at the Jamaican Jerk Festival (an annual event held in Broward County). Based on her phenotype (curly rather than "kinky" hair that did not appear to have been straightened with chemical crèmes, fair skin by Jamaican standards, ambiguous facial features) I surmised that she might be racially mixed. She was selling green tee shirts bearing pictures of the doctor bird, Jamaica's national bird. I approached her stall, examined the shirts, and purchased one. As we conducted the exchange I asked her if she had grown up in Jamaica, described my study to her, and invited her to participate. She agreed and we met for the interview a few weeks later in her Palm Beach County home. When I asked Nicole to describe race in Jamaica it did not surprise me that she immediately invoked the national motto, “Our motto is 'Out of many, one people,' so that should say something. There are very few people in Jamaica who belong to one specific race. Most people are biracial or multiracial so we can all identify with each other more easily. And there's very little racial segregation.”

I had already conducted more than half of the interviews by the time I interviewed Nicola and her invocation of the motto was already becoming a trend. That Nicola's reference to the motto was echoed by almost one-third of my respondents suggested that the ideology linked to this motto is rooted in Jamaicans' minds and influences their perception of race in Jamaica. It was, in fact, their immediate response to my question about race in Jamaica. Nicola's comment 'Our motto is 'Out of many, one people.' That should say something" suggests that in her view the motto, more than just an ideal, reflects the reality that is lived on the island. 
In fact, interviewees seemed to link the motto, "Out of many, one people," to their ideas about race in Jamaica. That is, the fact that they invoked the motto when asked to describe race in Jamaica suggests that hold it responsible for the understanding they hold of race there. Thus one of the reasons why participants dismiss the importance of race in Jamaica is the influence of the motto which indicates that while the island is multiracial, Jamaicans are "one people." Forty-four year-old Glenn was particularly anxious to explain the influence of the motto on his view of race, "I think the whole idea of race is stupid because I saw myself as a Jamaican person. In Jamaica, in school they instilled "Out of many, one people" and that's how I think a lot of Jamaicans see it. It's the motto. We talk about it in school, in primary school, I mean; it was instilled [italics added]. So we're very tolerant of people of different races and backgrounds." Also a Palm Beach resident, Glenn had resided in the U.S. for 29 years at the time of our interview. Describing himself as multiracial owing to his black, Chinese, and Indian ancestries, Glenn also said, "In school in Jamaica, I was proud to think we were 'Out of many, one people.' Everyone is mixed there. Some have less mixture than others; but I guarantee you, there are many with African and Indian, or African and Chinese backgrounds." Glenn refers to the motto because he really believes that it has influenced the ways in which Jamaicans think about race. He intimates that the motto is taught in schools with the intention of teaching Jamaicans, during their youth, to see the island as a multi-racial space, and to think of themselves as primarily Jamaican. As was the vision of Jamaica's Creole nation-builders, nationalism would trump old racial divides.

As did most participants who invoked the motto, Nicola and Glenn explained the motto: (1) as indicating that Jamaica is a multiracial, "melting pot" composed of different 
cultures and races that are both celebrated and appreciated; (2) are all racially mixed, so that they are themselves a blend of different races and cultures; and (3) as indicating that while Jamaica is composed of people of different races/cultures/nations, the Jamaican national identity and culture are paramount; racial and cultural differences, while celebrated and appreciated, are far less important. Based on their explanation, Jamaicans' ideas about race are constructed within a context in which racial distinctions are downplayed. The implication, as Glenn points out above, is that Jamaican society displays a great deal of racial tolerance, "So we're very tolerant of people of different races and backgrounds," he says.

These explanations suggest a situation in which the national "Jamaican" identity functions as an unbounded category. Different races, cultures, and ethnicities are celebrated within the nation, but owning one or more of these is far less important than belonging to the nation. Being Jamaican, then, is paramount to being "Chinese," "Lebanese," "black," or "brown." The motto thus implies not the absence of racial differences per se but the absence of rigid racial boundaries that significantly impact Jamaicans' lives in terms of allowing or denying them access to resources. The Jamaican state's strategy promoted through the motto was to become a post-racial society, to get past historical, rigid racial boundaries. Instead of the state doing boundary work, the state undid boundary work. The strategy was to overlay national belonging on top of racial divides and to help those divides lose their depth. This strategy helps explain why my interviewees, upon experiencing much more rigid color boundaries in the U.S., emphasize claims to a Jamaican national (and incidentally post-racial) identity that unites Jamaicans of all races. 
Biracial (black/white) Deborah held similar ideas about racial unity under the banner of nationhood. A university professor who had herself studied race, she was reluctant to declare the island to be entirely post-racial. Nevertheless when comparing the racial systems of the U.S. and Jamaica she also referred to national identity as a force/factor that unites Jamaicans of all racial backgrounds. "The key distinction has to do with the ability in Jamaica to hold on to a cultural identity, to claim a national identity in a way that becomes unifying across color and class lines," she explained to me. "So, for instance, when a Reggae Boys' [Jamaican soccer team] match comes, everybody gathers in the stadium and sits together regardless of racial or ethnic origin. And they can and do organize around that national identity." Deborah went on to state that the same thing occurs in the U.S. That is, Americans also have strong feelings of national identity which are displayed during international competitive sports events. "But," she said, "I think there is a much longer history of exclusion of blacks, Hispanics, and other minority groups from full claim to legitimate American citizenship. That is why you can have a rally with Sarah Palin at which people are yelling 'terrorist!' and 'He's an Arab!' in reference to Obama. This kind of thing can happen here because of the much longer history of xenophobia in the U.S." She suggests that, unlike in the U.S. where race divides citizens despite the fact that they all share a national "American" identity, all Jamaicans, regardless of racial identification choices or racial ancestry, are allowed full claims to Jamaican citizenship and become, as it were, members of one (Jamaican) "race."

Arguing in a similar vein, Audrey, a 35-year-old biracial (black/white) guidance counselor in a South Florida high school attributes the sense of being "one people" to 
demography. That is, most (91.61 percent $\left.{ }^{9}\right)$ Jamaicans identify as black and virtually all have some black ancestry.

I think the issue was that in Jamaica the majority [of people] looked the same, where here [in the U.S.], we're the minority. So the idea that we are "one people" probably comes from the fact that we were all so similar. There was light-skin, dark-skin, whatever, but we all pretty much felt we were the same race: Jamaican! Chinese-Jamaican, white-Jamaican, blackJamaican, brown-Jamaican: we were Jamaican!

What Audrey intimates but does not say directly is that within the largely black Jamaican population there is a variety of hues that are the result of centuries of intermixture among racial groups. Audrey, who describes her mother as black and her father as biracial (black/white), distinguished herself in Jamaica based on her complexion as "brown." She asserted, however, that this distinction held very little meaning to her since what mattered most, was that they were all "Jamaican." For participants, then, the argument is not that Jamaicans are unaware of racial differences. Nor is it that Jamaicans never make distinctions based on race or color. Rather, the argument these interviewees make is that these distinctions are rendered unimportant by their identification with their national identity.

Thus, while acknowledging the existence of different racial groups, respondents typically insisted that race was not a "major issue" in Jamaica. And a noticeable number of participants attributed that "fact" to the Jamaican motto, "Out of many, one people."

\footnotetext{
${ }^{9}$ This figure is based on 2001 Census data. For census purposes, race is counted based on selfidentifications. Therefore the figure may include Jamaicans with knowledge of non-black ancestry who nevertheless identify as black.
} 
The motto, they claimed, was not only taught in schools, but had also become part of the discourse of ordinary citizens. As explained in the previous chapter, Jamaica's motto "Out of many, one people" was developed as part of Jamaica's nation-building project that culminated in political independence from Britain in 1962. Communicating the idea of Jamaica as an island in which many races, ethnicities, and cultures are present and celebrated, the motto served to help develop a national identity that emphasized "Jamaicanness" and that minimized, in the minds of Jamaicans, the social importance of race and color. While the various mixtures of races, ethnicities, and cultures were to be celebrated, what was more important was the possession of a national "Jamaican" identity. Other post-colonial nations including those in the Caribbean embarked on similar projects during the first half of the twentieth century. A notable example is the efforts of former Prime Minister of Trinidad, Eric Williams, to develop both national pride and a national identity through various programs, projects and publications (Tsuji 2008). For Williams creating national identity and pride required a casting off of cultural dependence on the mother country, England, so that Trinidad and Tobago would become its own "mother." Williams' efforts were also geared toward the celebration of racial and ethnic diversity. The latter came with the understanding that this was "one nation." Williams' preoccupation was with how to convince the people of Trinidad to be both "ethnic" and "national" at the same time (Tsuji 2008: 1152).

In regard to Jamaica, Johnson (2005) argues that despite the evolution of hybrid cultural forms as part of a process of creolization, as the country approached its independence the presence of sharp distinctions among the racial and ethnic groups necessitated an ideology that emphasized "oneness." That is, this ideology of unity under 
the banner of nationhood was deemed necessary to counteract distinctions among these groups, and especially to dampen unrest sparked by perceived disparities based on race and color. As indicated in the previous chapter, scholars (Nettleford 1973, Vickerman 1999) have attributed the tendency among many contemporary Jamaicans to display a "lack" of racial consciousness to the nation-building project. In this way, state-sponsored rhetoric celebrating multiracialism while downplaying racial divisions coalesced into non-racialism and effectively muted race consciousness in many Jamaicans (Vickerman 1999). At least this was the goal of the state. Post-colonial leaders, moreover, have pointed to the absence of explicit racial dogma from Jamaican politics as one indication that their goal to overcome racialism has been achieved (Johnson 2005).

The fact is that the nation-building project had to invent non-racial nationalist rhetoric given that race really was still a major problem at the time of independence. The majority black population was still largely poor. Black power advocates argued that blacks were excluded from economic advancement. Tensions and divisions still existed between blacks and ethnic minorities, especially Chinese and Indians for these very reasons. And some scholars actually argue that the state's goals (muting race consciousness) were largely realized (Vickerman 1999). Therefore my participants' evocation of the motto which summarizes the nation building project, seems to indicate these scholars are correct. That is, in turning to the motto "Out of many, one people" to explain the absence or racial tensions in Jamaica, mixed-race Jamaicans, are demonstrating that they have be influenced by strong ideological norms denouncing racial discourse. 
What stands out in my interviewees' recollections of life in Jamaica is the harmonious relationships they recalled having with classmates, neighbors and others of varying races and racial mixtures. As Paul, a 26-year-old biracial (black/Indian) undergraduate student put it:

In Jamaica, it was it was different [than in the U.S]. I think we had neighbors that were Chinese, white, and then we had neighbors that were really white. But I don't remember my parents or anybody ever saying, "Oh those are Chinese, stay away from them." Or "that person is white, stay away from them." We all went outside and played all the time after school and I never thought, "I'm black, he's white," or "I'm black, he's Chinese." I've always had white friends but they were just our people to me. I never thought "I'm better because I'm black," or "he's better because he's white," or they never said that. So growing up I never had any of that in Jamaica.

While Paul clearly expresses his awareness of the existence of different racial groups on the island, he insisted that he never thought about these as signifying different social statuses. In claiming not to have been advised by parents or anyone to choose friends based on race, he suggests that racial harmony was fostered by a lack of racial (or racist) preferences and discourse among Jamaicans. Forty-three year-old Althea shared similar memories, "I grew up with Chinese friends, but the differences were not as pronounced. It did not make a difference whether your friends were Chinese or white Jamaicans. And also there was race mixing in my family between whites and blacks. So it just wasn't an issue." 
These participants therefore described Jamaica as a society in which race had ceased to be a significant axis of differentiation leading to social status distinctions. Race, they argue, was therefore not talked about. Althea made just this point while discussing her family, "Race was not discussed or at least it hardly ever came up. I remember that my mother never talked about it. My father was very fair and she was very dark. But the only remark her in-laws ever made about her was that she was very young. They asked him why he was marrying such a young girl." When I asked her, "So they never made comments about her skin color?" Althea replied," Not about color, no." Not "Race" but "Class"

It is clear that Jamaica worked hard to inculcate a post-racial national identity. But social scientists know that social hierarchies marked by boundaries that need to be maintained always lurk in societies. So if race was eschewed, what were the social borders that mattered in Jamaica? Around what do people do their boundary work? To answer these questions I turn to several interviewees' voices: “Racial prejudice does not exist in Jamaica, but social prejudice does exist," 27-year-old Andrew explained to me. A multiracial man with black, white, Chinese and Indian ancestry, he went on to explain that the key to understanding social prejudice is about "your earning potential," his phrase signifying socioeconomic class. His view was also echoed by 34 -year-old Cecile whose background is black, Cuban, white, and Indian. "We don't really have a race problem. What we do have though is a social class problem which still exists today," she explained. "I didn't have a lot of issues with [class] that were directed at me, but I saw it. It was very prominent. And 26 year-old multiracial (white, black, Chinese) Damian said, “With Jamaica it's not so much so a matter of race, it's class. You know, because you 
have the upper-middle class Jamaican people, black upper-middle class Jamaican people, calling the helper boy or maid "Old Nayga" ${ }^{10}$ you know. So I don't think it's about race as much it is about class in Jamaica to be honest with you." The strongest statement on how class is viewed as eclipsing race in contemporary Jamaican social stratification, however, comes from Christine. Forty-eight years old and of mixed ancestry (black, white, Indian), she insisted, “I don't think race is important. I think the question is class. Even though the largest percentage of those Jamaicans who fit in the poor class is of strong African descent, I would not say that there is racism in Jamaica. But I would say that there is absolute "classism" in Jamaica." She continued to explain how disparities in Jamaica are most extreme along income. "We have a population of approximately two million people, according to the census, and one percent of the Jamaican population might be called wealthy, five percent of the Jamaican population are working-class or middle-class, and the other eighty or ninety percent are poor working people."

Class, then, is identified as the principal organizer of distinctiveness and even a source of conflict in Jamaica. The above responses are illustrative of the whole data in that they point to how participants, when asked about race in Jamaica, deflect race toward class. The prevailing belief among participants is that one's location on the socioeconomic ladder holds more significance to Jamaicans than one's racial background. Therefore it is class, rather than race, that is used as the primary means of social differentiation and exclusion. In Jamaica, class determines in-groups and out-groups.

\footnotetext{
10 "Old Nayga" defined by another participant as: “. . . a poor, uneducated farmer, laborer, domestic helper; someone who is not a part of the wealthy class or the middle class; someone who is uncouth, lacking in social grace." Note that "nayga" is the Jamaican Creole version of "negro" so that its usage is associating people from the lower classes with Black (African) ancestry.
} 
Yet it is important to state that these four participants, as well as the majority of those interviewed, all identify themselves as middle-class Jamaicans. As was mentioned in the previous chapter, studies have shown that while poor urban and rural black Jamaicans tend to feel that race is a stratifying force in their lives, not just social class, middle-class Jamaicans tend to place much more importance on class as Jamaica's primary social stratification boundary (Alexander 1977, Thomas 2004, 2006, Vickerman 2001). Of course, not all middle-class Jamaicans have overlooked the role of race in Jamaica's social hierarchy. Black and brown middle-class intellectuals are increasingly interrogating race as a continuing, not eliminated, boundary and socially stratifying force, (Cooper 2004, Gordon 1991, Munroe 1991). Yet their scholarship has not necessarily permeated the thinking or discourse of the middle-class broadly speaking. My research certainly indicates that middle-class Jamaicans of mixed heritage generally do not see race.

Thus, one's location on the social hierarchy helps determine the importance one gives to class vis-à-vis race. It does not require much in the way of imagination to understand why middle-class Jamaicans, black and brown, might have internalized the post-racial doctrine while poor blacks may not have done so as completely. Jamaica's social hierarchy, as the last chapter showed, places racially mixed Jamaicans in the middle-and upper-class. As middle-class Jamaicans, then, my participants likely found themselves largely unaffected negatively by race. In some ways, their experience may be likened to whites in the U.S. who, unexposed to and unaffected by racial disparities on a daily basis, have been known to discount its potency — even its continued existence-- in U.S. society (Dalmage 2000). 
To this point, then, we have seen how several different criteria are used to determine social status in Jamaica. While this is true elsewhere, a key point to keep in mind is that whereas in the U.S. race is the principal social boundary marker, this is no longer the case in Jamaica - at least for many people in that society. Rather, Jamaicans draw upon multiple criteria to determine social standing including membership in families that have historically been part of Jamaica's upper-class or middle-class, income and/or profession, level of educational attainment, behavioral patterns, or residence. The latter criterion refers both to the type and size of one's home as well as its location. Twenty-eight-year-old multiracial (black/white/Indian) Jennifer explains this criterion: "I don't think people in Jamaica think about race very much because there's so much mixture. It's more about where you are from, or where you live: whether you live in uptown or downtown. To me, class is really where you live in Jamaica; that was more the concern: where you live."

The distinction made between those who reside "uptown" and those who live "downtown," 11 a distinction used in quite frequently in daily parlance in Jamaica, also featured in respondents' stories. "I guess I'd have to say that I am upper class," said multiracial (black, Chinese, Indian) Denise when I asked her to explain class in Jamaica.

\footnotetext{
${ }^{11}$ In Jamaica "uptown" and "downtown" have evolved into idioms that denote class. Thus "uptown" individual denotes a member of the middle or upper-class, is usually racially mixed and/or lightskinned and perhaps well-dressed. Importantly the individual also usually uses speech patterns that are less common among the urban poor. That is, she demonstrates the ability to speak English rather than only the Jamaican patois. "Downtown" refers to folk who reside in the poor urban areas. They are usually (though not always) dark-skinned, poor, and less refined by Jamaican standards in their behavior patterns and speech. Often the individual is not proficient in English. She understands it; but expresses herself most easily in the Jamaican patois. The terms "uptown" and "downtown" are used in reference to a geographical demarcation of Jamaica's capital city, Kingston represented by Crossroads - a busy intersection in the heart of the city. Generally, areas north of Crossroads are known as "uptown" areas and are the areas in which the more privileged are likely to reside, work and attend school.
} 
Below she explains the importance of and the meanings that are attached to where one lives:

I would say that I am upper class because I am UPT, which is the new slang now. When we say someone is UPT, we're saying that he or she is in the upper class. UPT is short for uptown. It's uptown versus downtown. I guess I did live in the uptown areas, but I didn't go to the uptown schools, so the difference with me is that I had more friends who weren't so much uptown. Some of them took the bus. And some didn't live in nice areas. As I get older I'm becoming more aware of it. I find myself thinking that gee, I lived in this house and my friend lived in a little tenement yard; but we were still really good friends. So I guess I had the privilege of seeing both sides since even though I was uptown, I still hung out with the downtown people.

Denise's statement that she related to "downtown" people even though she was "uptown" reflects the belief that there is a firm boundary between the two. It is not clear from this comment whether the boundary is based solely on class or whether, in her estimation, race also plays a part. What is clear is that participants believe that in Jamaica the distinction between "uptown" and "downtown" individuals is important. So important is that boundary that Denise expresses some surprise as she looks back and recalls that as a child she had crossed class lines and made friends with "downtown" Jamaicans. And her surprise suggests that a great deal of boundary-work is done around class.

My interviewees' convictions about the relative salience of class in Jamaica are buttressed by the social mobility gained by blacks since the middle of the $20^{\text {th }}$ century. 
Thus, multiracial Christine asserts, "People in Jamaica have gotten to the point now where because we have had many years of social democracy, because all of our leaders are black and admittedly so, because all our institutions are run by blacks, because all our teachers are black, our doctors are black, our bus drivers are black, and our domestic helpers are black, they no longer think of race as so important. All you see in Jamaica now are people who look black, or some variation of black. These include very welleducated ministers in our government, men and women, young and old, who are black, who have risen to middle-class status." The fact that for more than half a century blacks have been visible in various positions of leadership and influence, and that blacks have acquired access to material resources, eliminates race as a significant barrier to social mobility in the minds of many Jamaicans. Christine continued, "The reasons why Portia Simpson-Miller ${ }^{12}$ lost that election were not because she's black, but because they were able to say she's not a part of our class. They spoke about the language she used, about her close identification with hundreds and thousands of poor people in Trench Town ${ }^{13}$. They spoke about her lack of education. And these are the characteristics that defined her and determined the results of the election."

Considerable black social mobility and influence indicate to my interviewees that race and even color have ceased to function as bright boundaries in Jamaica. In the process class has taken over as the island's primary social boundary. The symbolic value

\footnotetext{
${ }^{12}$ Mrs. Portia Simpson-Miller became the first woman Prime Minister of Jamaica in March 2006 when Prime Minister P. J. Patterson resigned. Currently leader of the Opposition party (People's National Party) Mrs. Simpson lost the elections in September 2007 to opponent, Bruce Golding, currently Prime Minister and leader of the Jamaica Labor Party.

${ }^{13}$ Trench Town is an inner city area of east Kingston which is characterized by extreme poverty and crime. It is known as the political stronghold of criminals with affiliation to one of Jamaica's two major political parties.
} 
of class is such that Jamaicans use markers of class to determine who may do what. Thus, Christine points out, the country's first black Prime Minister, P. J. Patterson was deemed acceptable despite his dark skin, "But when you look at Percival James Patterson, when you look at his education, he's Oxford educated. He had the very best of the education system in Jamaica and then went on to Oxford. So he spoke the language of the wealthy Jamaicans, as well as the middle-class Jamaicans, and he cracked the global political society." Dark-skinned Jamaicans, then, by virtue of career and/or income, and by their ability to display the behavior patterns (manners, speech, dress) that are associated with the middle-class, might be accorded higher social status and treated accordingly.

The implication of all the above assertions is that Jamaicans do most of their boundary-work along the border of class, more so than either race or color. This implication is substantiated by my interviewees' testimonies. For example, female focus group participant Dana insisted that, “...the system that Jamaicans tend to operate on is class: if you're uptown, if you're privileged, if you have status in Jamaica. Your socioeconomic status is far more important to Jamaicans in terms of how they relate to each other, than color." Likewise biracial Audrey insisted that her family had rules that drew boundaries around class and norms associated with class, "So for instance we couldn't speak a certain way [implying that they were not allowed to speak the Jamaican patois ${ }^{14}$; we couldn't hang out or be friends with certain people who were seen as lower class. It

\footnotetext{
${ }^{14}$ The Jamaican patois, while a symbol of national pride, and while spoken by most Jamaicans, is still largely stigmatized. An important measure of social status is the ability to speak Standard English and to use the patois minimally or only in certain informal contexts. Audrey's father was thus likely prohibiting a reliance on the patois, rather than any use of it at all. This is self-administered boundary work via language.
} 
wasn't so much about color. It was just always the type of music, the people with whom you associated, like where people lived, what they did for a profession."

Boundary-work based on class was also reported in the area of entertainment. Multiracial (black/white/Indian) Cecile, while discussing the importance of class as a means of social distinctiveness, illustrated this point, “They used to have different carnivals. One was called Oakridge Carnival and it is supposedly exclusive. You could only attend if you had money or if you were from the upper-class. I remember a few friends who they wanted to attend. They were from the middle-to upper-class but they decided to pretend that they were from the lower-class and give the Oakridge guys a call indicating that they wanted that experience, that they didn't want to be part of the public Jamaican carnival. The people in charge made it very clear that they could not attend that special carnival. They had to fill out a form indicating their income, where they lived, what kind of cars they drove. It was that explicit."

\section{Intersectionality: Class Plus Race}

While my interviewees argue that social distinctions in Jamaica are made based primarily on class not race distinctions, I have already argued that Jamaica has, since the middle of the $20^{\text {th }}$ century, become characterized by a complicated inter-relationship between class, on the one hand, and race and color on the other. More than half of my informants (52.9 percent) pointed out that relationship: that in Jamaica race and class are closely intertwined. Twenty-six-year-old multiracial (black, white, Indian, Chinese) Michael explains the interrelationship, “In Jamaica race is intermingled with class. I can’t think of one without thinking of the other. So if you have lighter skin or straighter hair, 
then it means not just that you're from possibly a different race but you're also from a different social background, and your history and your experiences and the people you associate with are going to be different."

This relationship between race and color on the one hand, and class on the other is recognized by participants as being the remnant of the rigid social stratification based on race during slavery. Despite the socioeconomic gains that have been made by black darkskinned Jamaicans, persistent and pervasive poverty among the black urban and rural poor, and the concentration of wealth among the small white and brown elites, have continued to reinforce a tendency among Jamaicans to associate color with class (Nettleford 1998, Thomas 2004). Participants' testimonies reflected this tendency. Fortyeight-year-old multiracial Christine, for example, told me, "They [blacks] are the majority of the population, and they are, I would say, the most underprivileged historically, coming out of slavery and not having had the wealth handed-down, you know, slave masters, who were white and had multi-racial children, or who came as business people and handed down their wealth, or who came as Chinese merchants and handed down their wealth." And 24-year-old Denise, a multiracial (black, Chinese and Indian) graduate student, said, "It's really unlikely that you'll find someone in Jamaica who is light-skinned but not upper-class, or who does not live in certain regions. I mean you very rarely find somebody who is light-skinned who does not drive a fancy car or is not living in a nice neighborhood. I hope that doesn't sound snobbish. I guess I became more aware of that when I went to Cuba in 2003. It was the first time that I saw lighter skinned people, white people lining up for the bus. In Jamaica, you don't really find light skinned people lining up for the bus. That's the truth." 
The racial disparities that Denise perceives are revealing. Jamaicans are not only conscious of racial differences but are also cognizant of social disparities on the island that are based on race. As Denise says, Jamaicans assume that non-black or racially mixed light-skinned individuals reside in the better neighborhoods, attend better schools, drive better cars (or simply do not take the bus). Her statement, then, also demonstrates that Jamaicans, despite the fact that many deny doing so, place individuals into categories that are based not only on class, but additionally on the bases of race and skin-color. That is, on the basis of phenotype Jamaicans make assumptions about a person's place in the greater social hierarchy. Anticipating that participants would entwine race and class, I had posed this very question to the focus group. And they provided examples of the tendency to use phenotype as a marker of social status. As one female participant put it: I think that what is more important to know is that while class is more important generally speaking in Jamaica one tends to identify your class by your race. So if you have not spoken and I don't know how you speak (that is, whether you can speak English or can only speak Jamaican patois) the first the first thing I am going to use to identify your class, the thing that is the most important identifier is how you look. If you have curly hair, if you have brown skin, typically you're from a higher different class. I guess to sum it up, class and race are important. I would say that class is more important in our society. But how do you define one's class? Typically if you see one person just standing, and you have no idea where he lives, what kind of car he drives, then you'll make that determination based on his race. That's how you're going to define that person. 
While asserting that class is Jamaica's primary social boundary, participants also show that color serves as an initial indicator of class - a fact that complicates their understanding of the importance of color. The result is a complex and sometimes apparently contradictory situation in which class and color intersect as powerful symbolic, yet deeply important, social boundaries. In this way, participants' views reflect the complex construction of color discussed in chapter three.

The contradictions inherent in Jamaica's social hierarchy lead to ambivalence in Jamaicans about the exact nature of the relationship between both race and color, as well as between these and class. The responses of my participants reflect such uncertainty. As they grapple with the question of which (class or race) is more important, it become clear that while as the above quote demonstrates participants deem race less salient than class, they also believe that there is a relationship between race or skin color and class. That is, that race is involved in determining class. A male focus group participant's comments help to explain this relationship:

But it does seem that race has played a very instrumental role in my Jamaican experience primarily because although Jamaica seems to be more caught up with class, race does identify class. So for example you could have many different class structures which determine what you can do in Jamaica; but color does play a part and, as such, race therefore comes into play. As a light-skinned Jamaican who some people call "redman," "brown-man," or "white man" I often enjoyed certain privileges based on the assumption people made that I belonged to a particular class meaning the ruling class, the high privileged class, or those with money. 
So is race there? Yes in that about 90 percent of Jamaica is the same or close to being the same race, again depending on how you define race. Class is really the more defining thing in Jamaica in my experience. But race does play a part because it helps determine how we assume one's class.

This participant's ambivalence about the roles of race and class rests on the fact that despite the importance he assigns to class, he also recognizes that people's daily experiences vary because of their appearance (especially skin color). The fact is that, in Jamaica, as well as in the U.S., skin color evokes assumptions about one's place in the social structure (Austin-Broos 1994, Grillo 2003). Since Jamaicans tend to associate lighter skin complexions with higher social status, this focus group participant, by virtue of his skin complexion, enjoyed a degree of preferential treatment. People assumed his social status was higher than theirs and generally treated him accordingly. Therefore, while he concludes that class holds more importance in Jamaica, he cannot possibly dismiss the ways in which Jamaicans use color to distinguish people, and to determine their place in the social structure.

Interviewees' ambivalence regarding the relationship between race and social status is largely due to the fact that in Jamaica as elsewhere identities are not negotiated separately but are mutually constituted (Austin-Broos 1994, et al. 2006, Grillo 2003). That is, social status is determined by a variety and sometimes, a combination, of markers: color, dress, speech patterns, residence, employment, family and so on. People are not always aware of these relationships; instead, as with my interviewees, they tend to see only one or a few factors which influence social status determinations. In the case of 
Jamaica, the blurring of and shifting of boundaries drawn by race and color during the $19^{\text {th }}$ and $20^{\text {th }}$ centuries helped raise the importance of class over race in people's minds. Despite such shifting and blurring of racialized ideas over the value of African heritage and of British norms as the "standard" for behavior, color and class continue to entwine Jamaica's social hierarchy. Despite state-sponsored support for indigenous music, dance and art forms (through the Creole multiracial project) and despite growing pride in blackness, color continues to represent/indicate status to most Jamaicans.

Viewing color and class as inter-related in Jamaica is confirmed by the work of Alexander (1977). For example, one of Alexander's respondents whom he named Sears asserted "in rapid succession that it is class not race that counts in the perception of people, that people are very conscious of hair, and that people use race terms without much conscious thought" (Alexander 1977: 424). Alexander argues that ambivalence about the significance of race has two sources: (1) the belief that since race makes invidious distinctions among people, it is not something which ought to be discussed and (2) informants' uncertainty about the "relative importance of achieved and ascribed characteristics" (Alexander 1977: 425). That is, while on the one hand respondents held to notions of a individual's ability to make of herself whatever she wanted, they also believed that external forces that may hinder success despite one's best efforts. Moreover, one may not have much control over how one is perceived by others since in Jamaica color signifies social location to many. 


\section{Color Draws Boundaries in Jamaica}

\section{Privilege and Assumptions of Privilege}

At the beginning of the chapter, the story of biracial (black/Indian) Karen demonstrated the special meanings attached to being racially mixed in Jamaica. Karen's story suggests that given the strong association between color and class, being racially mixed in Jamaica involves the assignment a social status that is perceived to be higher than that held by so-called un-mixed blacks. This is especially so for those individuals whose ambiguous phenotypical features make their non-African ancestry obvious. Thus Karen told me, "So I guess while I was there, because I'm mixed, I had the sense that I was more elite, and that people looked at me differently."

Twenty-six year-old multiracial (black/white/Chinese) Justin agreed:

The positive thing about being a non-black person in Jamaica is that there is preferential treatment, meaning preferential treatment from the blacks. I experienced this in both high school and as an undergraduate student at the university. The thing is it just puts you in an uncomfortable situation. Even someone like me who really doesn't think myself that way since I have pretty much have all the different races in family. It's bad to see how a black person would favor helping out a Chinese or white person over helping out his own black brethren. I've seen it. That's how it is.

I studied Justin's features as he spoke. His fair skin, straight black hair and slightly slanted eyes bespoke his Chinese ancestry. In fact, his black ancestry was not obvious to me. His physical appearance evidently marked him as belonging to minority ethnic (and privileged) groups, as holding higher social status and somehow deserving of preferential 
treatment by dark-skinned Jamaicans. In stating that he did not perceive of himself in that manner, he places the responsibility for such experiences on dark-skinned blacks. Similar sentiments about color-based privilege were shared by biracial (black/white) Deborah, "I would say that, certainly when I was growing up one's socio-economic position and one's racial identity - it's kind of hard for me to separate race from color - might grant one a greater or lesser degree of access. So there were places where because I am light complected I was granted greater privileges." Focus group participant, biracial (black/white) Christopher, for example, insisted that he was "allowed admission to allinclusive hotels without question" simply because of his skin color. He continued, "But a friend of mine who looked more genuinely African descent or only African would not have such luck." And also by multiracial (black/white/Indian/Chinese) Vivica who said, "Well you know the brownings [laughing] are better off than people with darker shades. And of course everybody assumes that the browning is a better and more educated person. I don't know what caused it. But as a browning, I seemed to have had more opportunities."

Brown privilege was often expressed by my interviewees in relation to notions of beauty, especially for women. That is, racially-mixed Jamaicans whose phenotypes reflect racial ambiguity and suppressed their black ancestry, they said are deemed more beautiful in Jamaica. This tendency is revealed in Karen's story at the beginning of this chapter. Biracial (black/white) Norman explains that, "In Jamaica the epitome of beauty was defined based on people who have European features primarily. For example, Miss Jamaica year in and year out used to be a Caucasian-looking woman. And even though this has changed somewhat over the years, I would argue that for the men, like my 
brothers and uncles, the epitome of a beautiful woman generally bears European features, or is a fair-skinned type of woman." While Norman emphasizes the importance of European features, biracial (black, Indian) Karen's experiences show that other nonEuropean features are idealized as well. In fact, they demonstrate that what's important is bearing a minimum of the features typically associated with people of African descent. Women, like Karen, with Indian, Chinese, or Middle-Eastern ancestries are also likely to be considered more beautiful. It is clear however, that in considerations of physical beauty Jamaicans emphasize fair complexions and long straight, wavy or curly (rather than kinky) hair. Several participants made this very point. "Well the concept of beautiful" says biracial (black, white) Althea, "means that you would have lighter skin, long hair." And biracial (black, white) Audrey said, "The lighter your skin color was the more beautiful or the more favorably you were seen."

A clear trend emerged in which participants agreed that as mixed-race Jamaicans privilege had been part of their experience on the island. This is a significant finding as it is one indication of the meaning attached to color in Jamaica. That is, the fact that racially mixed Jamaicans have experiences of privilege in their homeland demonstrates how, despite their assertions to the contrary, color still draws boundaries on the island. This trend is not mere perception. Scholars for some time have noted that the racially mixed population has historically held a place of some privilege vis-à-vis unmixed blacks (Campbell 1976, Henriques 1968, Heuman 1976). Studies of post-Independence Jamaica (Alexander 1977, Barnes 1997, Miller 2001, Mohammed 2000) find that black features continue to be denigrated while light skin and non-black phenotype idealized. My data show that notions of brown privilege along with preferential treatment and ideas about 
beauty persist. That such preferential treatment continues to be granted reflects the persistence of deeply internalized notions about black inferiority (Lowenthal 1973). And this fact has implications for the meaning of color to Jamaicans. Based on interviewees' experiences as documented above, privilege for mixed-race Jamaicans was not only about family access to or control of material resources. Rather the belief that they were privileged was reinforced by special advantages accorded them by dark-skinned Jamaicans. That mixed-race Jamaicans are accorded high social status and treated as such is, however, not the whole story. The data clearly show that dark-skinned blacks have not always acted favorably toward those deemed "privileged." Black Boundary-Work: Privilege but Resentment and Exclusion Too

While my interviewees agreed that as mixed-race and light-skinned individuals they enjoyed privilege over darker-skinned Jamaicans, their experiences were not always pleasant ones. The assumption of privilege and of higher social status at times resulted in boundary-work on the part of dark-skinned blacks. That is, there is evidence that when dark-skinned blacks assumed that individuals with lighter complexions and European or other non-black phenotypes were privileged and wealthier, they translated these perceptions into efforts to create or reinforce boundaries of exclusion. Biracial (black/Indian) Albert spoke bitterly about his experience with such assumptions. "There were a few times while I was growing up," he recalled. "I was in school-I think in primary school-that because I wasn't fully black, I was presumed to have money. It's a natural stereotype in Jamaica that people who are mixed come from money. So I was always the last to be chosen for certain things. For instance, I found out after the 
Common Entrance Exam ${ }^{15}$ that the teachers used to conduct individual tutoring for certain children in class. I was never told about this. And they trained them in order to make sure that they got government scholarships because they were poor blacks." And, Albert told me that these types of experiences were not limited to his primary school. "In high school there was this teacher who was in charge of the interviews for going into sixth form, ${ }^{16}$ because as you know, when you graduate from fifth form, you have to go through interview for one of the few sixth form slots. Although there was an entire panel of teachers, it was this teacher who asked the questions. At the end of the interview, she said to me, 'Albert, tell me why should we let you go to sixth form? Because after all, you are brown and you come from money. You're going to do nothing for Jamaica!'” The latter confrontation with Albert's high school teacher and the fact that he had been deliberately excluded from certain opportunities, demonstrate that assumptions of brown privilege evoke expressions of resentment from darker-skinned black Jamaicans. The teacher's comment "You're going to do nothing for Jamaica," moreover suggests that she did not consider "browns" to be authentic Jamaicans. Such expressions are important as they serve as additional evidence that Jamaica reflects less racial harmony than participants have suggested.

\footnotetext{
${ }^{15}$ The Common Entrance is a standardized examination that until 1998 was used to award successful candidates a place in one of the island's high schools.

${ }^{16}$ In high schools in Jamaica, the Grade, as in level in school, was originally termed "Form" following the British system. Students began high school in first form (Grade Seven) and at the end of fifth form (Grade 11) sat the Cambridge General Certificate of Education Ordinary Level Examinations the results of which determined eligibility for promotion to sixth form. The latter was divided into two years (lower sixth and upper sixth) at the end of which students sat the Cambridge General Certificate of Education Advanced Level examinations. These British exams have been replaced by the Caribbean Examinations Council (CXC) and the Caribbean Advanced Proficiency Exams (CAPE) respectively. Select high schools have added an interview to the screening process.
} 
Albert's stories also demonstrate that resentment of brown privilege often resulted in boundary-work. Several examples of such boundary-work emerged from the data, but the most poignant example is that of Brian, a 37-year-old biracial (black/white) man who grew up in an urban area in West Kingston. Brian told me that he had many negative experiences in Jamaica due to his physical appearance. Brian's white father left him and his black Jamaican mother when he was still a child, and returned to England. After his father's departure, they moved to a town in the inner city in which his mother's family resided. It was there that he had his earliest experiences with resentment from darkskinned Jamaicans:

When I was younger in Jamaica, the area in which where I grew up was mostly black. I grew up in a ghetto. I had issues with my identity because people would pass my home would classify me as a "sailor-man pickney" [child of a sailor]. So during those days I started to wonder about my identity. Because although I grew up knowing that my pigmentation was different than the rest of my family, they did not treat me as a white child. They did not treat me as being a black child either. They simply treated me as a child. Yet on the streets people often passed by me and were critical of me especially whenever I took the public transportation. People told me I should not be taking the bus. They said, "Yu a white man." "Yu a sailor-man pickney." "Yu madda sleep with a sailor." [You are white. You're a sailor's child. Your mother slept with a sailor.]

Brian's physical appearance evidently marked him as an outsider. His blond hair, blue eyes, and very fair complexion were especially remarked upon during his time in 
that inner city town. Brian spoke of having been rejected by members of the community who insisted that because he was white he did not belong there. His experiences of being harassed in public spaces, of being told to get off public transportation because as a white, and presumably privileged, boy he should not be taking the bus, and of being called a "sailor-man pickney," indicate that because of his skin complexion he was perceived as an outsider. He recalls feeling that he had to prove that he was "one of them."

Brian's experiences are primarily about color; but they are also about how color and class intersect in Jamaica. Members of the community ascribed higher social status to Brian because he appeared to be white. They resented the status he seemed to represent. In so doing they were patrolling and reinforcing the boundaries that determined in-groups by drawing lines of exclusion. Since in Jamaica color and class intersect to determine social status, Brian's skin complexion determined that he might not be accepted as part of that inner city community.

Brian explained that he continued to have those experiences of exclusion even as an adult, "As a grown-up I used to play football [soccer] for communities that are basically garrison communities. ${ }^{17}$ So I faced it also a grown-up where they would say, 'Wey dis white bwoy a do ya?' [What is this white boy doing here?] or, 'Dem bwoy yah rich! Dem bwoy nuh fi dey ya! A poor people ting dis.' [That is a rich man He should not be here. This is for poor people.] And usually it was not until after they had had a chance to get to know me that they would classify me as one of their own. 'Rhatid him mother

\footnotetext{
${ }^{17}$ Garrisons are inner city communities in sections of Kingston which are known for extreme poverty. They are usually controlled by hardened criminals (drug lords or "dons") who possess connections with one of the two major political parties.
} 
black! Him brother dem black! All of him friend dem black! Dat yute deh nuh really a uptown yute!' [Damn! His mother is black! His brothers are all black! All of his friends are black! He is not really an uptown youth!]"

The fact that whenever residents met his mother or siblings who all appear to be black, all was well, but that on his own he was just perceived as white, deemed to be privileged and therefore, an outsider demonstrates how closely Jamaicans (especially the poor) link skin color to social status. It also underscores the assertion of most participants that while color is often linked with class, it is the class distinction that matters most to Jamaicans. In other words, while it was his color that elicited initial reactions to him, it was really the social status that his color represented that made his presence objectionable. He was deemed an outsider because his color suggested that he was from a different class. As a "white" man he could not possibly belong to their community. Only knowledge of his black relatives, could legitimize his presence, and render him acceptable to the community.

Patrick, also 37-years-old, told me he considered himself "mixed" while in Jamaica owing to his black, Mexican, Lebanese and Italian ancestry. My notes about his physical features indicate that he appeared to be "Indian" based on his somewhat dark brown complexion, straight dark hair, and the absence of the facial features typically ascribed to people of African descent. (It turned out that Patrick was not aware of any Indian ancestry.) Like Brian, Patrick shared that because his phenotype marked him as "privileged" he had encounters in which dark-skinned Jamaicans expressed resentment, “When you're racially mixed sometimes people despise you too for no reason; just because you're mixed. They do it because they think that you're more privileged." I 
asked him to share a story that illustrated this point and he continued, "My first experience with any form of, I'll call it 'racism' was in high school. When I was in first form, people use to make comments like I'm 'Indian,' I'm 'uptown,' and they would treat me differently. It took a while for me to get accepted. I remember when we had P.E. [Physical Education] I never got selected for teams. I would sit down and watch.”

Thus, because of his physical appearance, Patrick stood out among his peers in the high school he attended - a high school in Kingston that typically attracts students with darker hues. As he put it, "In my classes most of the students were of a darker complexion." Yet the difference in skin tone is not so much the point here. What matters is that due to his appearance Patrick feels he was treated differently as he was racialized as "Indian," viewed as "uptown," and excluded from sporting teams. Similar to Brian, lines of exclusion were drawn around him by darker skinned Jamaicans who felt he did not "belong" to their group.

The above stories demonstrate that class is not the only border around which Jamaicans do boundary-work. Color evidently also holds enough importance to warrant a great deal of boundary-work as well. It is clear that this is so largely due to the fact that Jamaicans associate color with class. The legacy of a history that privileged white and brown over black (dark-skinned) Jamaicans is evident in resentment among the latter. And as part of this resentment, and in reverse of how racial privilege operated under slavery, it is those of lower status who do boundary work to keep the privileged away from their territory. The stories of both Brian and Patrick demonstrate this fact very well. 


\section{Brown boundary-work: Racial Exclusiveness}

As may be expected, given the historical privileged position of non-blacks in Jamaica, boundary-work based on color was not conducted only by dark-skinned blacks. Interspersed throughout participants' stories were examples of various types of boundarywork by privileged groups (whites, browns, and ethnic minorities) demonstrating racial exclusiveness and even outright discrimination. Multiracial (black, white, Chinese, Indian) Michael provides an example from his own family. Explaining that his paternal grandfather had come to Jamaica directly from China he said, "My father's grandmother rejected him because he was not purely Chinese. Chinese are very clannish and they tend to stick to their own kind. So being a half-breed is looked down upon." Similar thoughts were shared by biracial (black/white) Patrice when asked to describe race in Jamaica, "There were clear distinctions with Jamaican Chinese: they stuck together. As I recall the Chinese population at my school did not mix very much with the black children. They didn't leave school together or hang out together after school. They stuck with each other. So I saw clear distinctions where that was concerned."

Among the factors, then, that contradict assertions that Jamaicans are "one" under the banner of their national banner identity are stories of "clannish" behavior especially among ethnic minorities and whites. Participants shared experiences for example in which they attended parties at which only white, light-skinned, or mixed-race individuals were present. Stories about racial exclusiveness were generally shared by those participants who, by virtue of their own experiences, had reason to be aware of such. These were usually individuals who were likely to be invited to 'white only' parties because although they also possessed African ancestry, their phenotype, and perhaps, 
their socialization, did not make such ancestry obvious. Multiracial (black, white, Indian) Caroline is one example. Her light skin, long brown hair and fine features gave little indication of her black ancestry. Caroline had insisted that while Jamaica was a "classist" society, race also held some importance there. When I asked her to explain she said, "I have been to functions and parties in Jamaica where the only black people who were present were the help (waiters, waitresses and bartenders).” And multiracial Patrick whose experiences with exclusion in school were shared above told me, "There are other sides in Jamaica, different communities. And although it's not as intense as it is here [the U.S.] the subject of race does come up. I have been to parties in which only high colored Jamaicans are present." "What do you mean by 'high colored'?” I asked. He replied, "You know, like the lighter complexion."

Thus, by and large, participants' stories indicate ways in which race and color still draw boundaries in Jamaica. It is therefore curious and telling that participants largely deny the social significance of race, despite evidence to the contrary that appears in their own stories. The fact that my interviewees' testimonies contain contradictions reflects the complexities that characterize Jamaica's social hierarchy in which status is based on groupings of race and/or color, and class (Austin-Broos 1994, Vickerman 1999). While color and class both constitute factors determining social status, these groupings intersect and overlap making the maintenance of really bright boundaries difficult. That is, the complex interrelations between race and color on the one hand, and class on the other, render boundaries drawn by all three (race, color and class) to be blurry - that is, ambiguous in terms of parameters determining individuals' locations on either side. The 
blurring of those boundaries in turn permits movement across them. It is for these reasons that Jamaicans possess complex understandings of race and color.

As I argued in the previous chapter, social status on the island is marked by contradictions that were produced by historical and social forces that have shaped Jamaican constructions of race and color. Vickerman (1999) summarizes these factors:

Jamaica is, at one and the same time, a country that has traditionally denigrated African ancestry, but not so much that it has prevented upward mobility for some of these individuals; confined the mass of the black population to poverty, but historical changes in the society have loosened the traditional correlation between skin color and social class; exhibited a "white bias," but the society has defined race so broadly that the exact meaning of racial designations is subject to a good deal of negotiation; and, overall has been quite racially conscious, yet strong social norms prohibiting race thinking have effectively convinced many in the population that race is not a factor in Jamaican society. (Vickerman 1999: 26)

While in pointing to the muting of race consciousness Vickerman makes a valuable point, it is important to reiterate that this does not mean that in the minds of Jamaicans the society is entirely devoid of racial concerns. My informants' stories demonstrate this point. Yet black social mobility and the presence of blacks in positions of significance, combined with a nation-building ideology downplaying the importance of race, have produced in many Jamaicans a great deal of ambivalence about the importance of race. This ambivalence is reflected in their stories. And their recollection 
of a society characterized by very little racial tension despite the apparent socio-economic stratification along color lines renders their ambivalence understandable.

\section{Chapter Conclusion}

To conclude, my data show that, by and large, mixed-race Jamaicans recall a society in which race held little social significance. That is, race had little or no impact on one's daily experiences or chances for social mobility. They attribute the society's less racial nature to inculcation of the motto, "Out of many, one people," which, they argue, reflects the society's appreciation for multiracialism. They argue, however, that the society remains unified under the banner of national identity to the extent that racial distinctions then are subdued. The motto had been crafted by the state with the intention of muting racial consciousness; and participants' assertions suggest that the state achieved its goal. By and large my respondents agree that class, not race, is the boundary along which Jamaican society is organized and divided. Several examples of how class distinctions work are provided.

Yet even as Jamaicans claim they are all one and the same, they provide numerous examples of the opposite. Jamaicans continue to entwine class and race, indicating that race (viewed through skin color) is more important than they claim when asked directly. Their stories are saturated with evidence that contradicts notions of Jamaica as post- or even non-racial. Stories of exclusiveness especially among whites, browns and Chinese, of brown privilege, and of resentment from unmixed blacks of the disparities they perceive, are all indications of both overt and covert boundary-work along lines of race and color. 
In this chapter I argue that based on participants' stories social status in Jamaica is determined by more than color - also class (measured by education, employment, family, residence, speech). I also argue that while no longer drawing bright boundaries, race and especially color do draw blurry boundaries that are somewhat permeable. Such permeability implies that large numbers of individuals may cross social boundaries regardless of color. And that fact combined with deeply rooted notions muting racial discourse results in a tendency especially among middle-class Jamaicans to be ambivalent about the role of race. Thus my interviewees largely eschew the importance of race (and color) in Jamaica, and they argue that it is class that draws bright boundaries. They make this argument despite stories from their own experiences that demonstrate that color still holds strong symbolic value for Jamaicans. As racially-mixed Jamaicans, they experience that meaning in ways that are largely beneficial to them. The very fact that there is resentment on the part of dark-skinned Jamaicans demonstrates their privileged location in the social hierarchy relative to unmixed blacks. Regardless of such expressions of resentment, since most of my participants bear phenotypes that reflect their racially mixed ancestry, they benefit from the symbolic value attached to color in Jamaica. How will these brown Jamaicans who despite their privileged past deny the importance of race, experience the legacies of the one-drop rule in the U.S.? It is this question that the next chapter addresses. 


\section{CHAPTER V}

\section{Encountering Boundaries and Boundary-Work in the U.S.}

I met 42-year-old Caroline late in the afternoon in her office - a small real estate company owned by her and other family members. As Caroline prepared for the interview, I studied her features. Based on her phenotype I thought she appeared to be white. I also thought that in the South Florida context her skin complexion, which was a little darker than one might expect from Anglo-Americans (or white Americans), and her dark brown hair might possibly lead to characterization as Hispanic by some onlookers. I studied her facial features as well and noted her very straight nose and thin lips. There was, in my estimation, little to indicate her black ancestry.

Caroline indicated that she had lived in the U.S. for 19 years. When I asked about her early racial experiences in the U.S. she said that her only racial encounters had involved her Jamaican husband whom she described as "tall and dark and handsome." "We had just moved here and one day we stopped at a gas station to get gas and this African American young lady started quarreling with my husband," she recalled. "I was in the car. He had gotten out of the car to get gas. And then I said to him: 'Do you know her?' He said: 'No but she's quarreling with me.' She was cursing him. She was asking: 'Why doesn't he stick with his own?' I didn't understand. It was not until we had driven off that I got what she was saying." "That is a very interesting story," I told her recognizing that Caroline had been interpreted as white. "What was the other experience?" I then asked. She continued, "The other one was when we went to see Jungle Fever [the 1991 movie about a love relationship crossing racial lines, the 
advertising for which featured a black and a white hand with the fingers laced and meant to be provocative] at the cinemas. As we were walking out after the end of the movie a lot of people were staring at me as if that was the only time. ..." She hesitated so I asked: "They thought they were seeing an example of "jungle fever?" "Right!" she exclaimed. We both laughed. I continued: "So how did that experience at the gas station make you feel?" "Well," she replied, "I wanted my husband to return (we had already driven off) so I could confront her and tell her off. But he refused to do so. I wanted to tell her that he and I had come from the same place. I was amazed. I couldn't believe what I had heard. I thought she had a nerve. I mean I didn't understand how she could think he and I were different, because, to me, we were both Jamaican. Now I can look back and I can say 'Ok she's not coming from the same place as we are.' So to her one is black; one is white. But that's not how I was raised."

Caroline's statement "she's not coming from the same place as we are" reflects her realization that in migrating to the U.S. she had entered a racial system that differed in some ways from the one she had left behind. And her latter statement "that's not how we were raised" shows how her reaction to those experiences were influenced by her memories of her experiences in Jamaica. As illustrated in the last chapter, my informants' stories about their memories of Jamaica reflect a social construction of race and racial identification there that is different from that of the U.S. There, the boundaries drawn by race are blurred rather than bright. Under the motto "Out of many, one people," Jamaicans recall that on the island race holds relatively little salience vis-à-vis class, which today functions as the primary criterion for determining social status. Racial mixtures are perceived of and celebrated in Jamaica as "normal;" everyone is "mixed," 
and there exists relative fluidity as far as racial identifications. Mixed-race Jamaicans like Caroline enter the U.S. with perspectives about race that are framed by these memories of race in Jamaica. Thus the African American woman's question "Why doesn't he stick with his own?" initially held no meaning for her. Given her Jamaican understanding of race, she and her husband were not different, but were the same; that is, they were both "Jamaican."

What follows is an analysis of my informants' encounters, through their experiences of racialization, with an unfamiliar racial system in the U.S. During my interviews with them, participants were asked to share their racial experiences since entering the U.S. Based on these experiences, they were asked about their impressions of race in the U.S. and how race in this context might be similar to or different from race in Jamaica. They were asked about their reactions to their experiences and observations. While there were various responses to these questions, the ensuing highlights those responses that occurred most frequently and that seemed most important to respondents. They have been chosen because the frequency with which they appeared in the data indicates trends in the racial thinking of my sample. ${ }^{18}$

\section{Race Draws Bright Boundaries in the U.S.: The Centrality of Race}

It never dawned on me about your skin color or anything, until I came to America. Here, it doesn't really matter where you come from, but just

\footnotetext{
${ }^{18}$ Note that the stories that follow reflect participants' descriptions of and impressions about their experiences in the U.S. Descriptions of racial boundaries in the U.S. are therefore written as they are viewed by participants themselves. Except for one sub-section that is specific to South Florida, the stories largely generalize about the U.S. based on respondents' experiences and observations. Therefore, for the most part, the descriptions that follow do not necessarily reflect regional variations as far as racial categorization and the one-drop rule.
} 
because of your skin color they look at you differently. When you walk in the store, when you even go to work for people, they look at you differently. I didn't know before I got here that race was such a big thing or that people really took time out and were so interested in it. (Anita, biracial: black/Indian)

Given their idealized memories of a virtually "non-racial" Jamaica and taking into consideration similar findings by previous studies of black immigrants, it did not surprise me that participants such as Anita commented at length on the relative salience that, in their view, race holds in the U.S. especially as compared to Jamaica. In fact, when participants were asked if they ever thought about race, most replied that they had not done so, or had rarely done so, until they entered the U.S. where race holds much importance. Anita's comments exemplify a larger pattern of sentiment shared by most participants in the study. They described the processes by which they learned that in the U.S. their "race" has a significant impact on how they are perceived by others. The relative importance of race in the U.S. holds implications for this racially mixed group of Jamaicans most of whom believe that they lived a virtually "raceless" existence in their home country only to find that in the U.S. race lurks everywhere. Race as a bright boundary in the U.S. has implications not just for how participants are perceived and treated but also for how they respond to their various racial encounters. I share below participants' stories of how they learn about the relative salience of race in the U.S., and the implications such salience holds for then. 


\section{It's Because I'm Black: African Americans and Race}

Respondents' experiences with race and racial boundaries in the U.S. occur in large part via their encounters with African Americans and with what they view as African Americans' hypersensitivity to matters related to race. An example, is 27-yearold Andrew, who described himself as "mixed" owing to his Indian, black, Chinese, and white ancestry. Andrew was particularly caustic in his critique of African Americans, asserting that, in his view, they are subject to a "form of mental slavery." "A lot of people like to find excuses for why they can't succeed," he said, "so they think, oh it's because I am black why certain things aren't happening or I didn't get the job because I am black." He continues:

[Race] might play a role; but I think when you start constantly saying that 'It's because I am black' you are making yourself a victim, and I was taught never to get up and make myself a victim. . .Sometimes it has nothing to do with being black. It has nothing to do with your skin color sometimes. I see what people from the Caribbean with the same skin color have come to America and achieved versus what black Americans have achieved. And the only difference I can see is the way we were raised. We were not brought up in a racial society. We were not constantly seeing race or making ourselves victims. We did not always assume that problems occurred because we're black. And it seems that black Americans automatically jump on the idea that it is because they are black. Andrew's harsh critique reflects opinions shared by most participants, who, by and large, were critical of African Americans, especially of their focus on race. Interviewees 
accused African Americans, stating that they "have a chip on their shoulder," are "too militant," "make excuses," "assume that every negative experience is based on racism," "have made themselves out to be victims," use racism "as an excuse for bad behavior," and "think they can't achieve." Such critiques reflect opinions that have long been shared by foreign-born blacks who live in the U.S. and whose uneasy relationship with African Americans is well-documented (Foner 2001, Hintzen 2004, Waters 1999, Rogers 2001). Waters (1999) attributed the tendency among West Indians in New York to be highly critical of African Americans' concerns about race to long-held beliefs that it is possible to overcome racism by hard work. Moreover West Indians view themselves as highly successful in comparison to African Americans especially in the workplace. If they, despite being blacks and foreigners, are able to succeed, they ask, why then can African Americans not do the same? As Hintzen (2004) has shown, West Indian blacks have both been viewed and have viewed themselves as a "model minority" largely due to beliefs about their relative success vis-à-vis African Americans. Hintzen argues that while these beliefs have been discounted by studies that have provide evidence to the contrary, they are evidently still held dear by West Indians.

Forty-three year-old Patrice shared observations that were very similar to Andrew's. As a second-generation biracial woman with dark skin, she had always conceptualized herself racially as black. Thus being viewed as black in this country is neither strange nor objectionable to her. Yet, like Andrew, Patrice remarked on the fact that African Americans identify racism as the principal factor behind virtually any negative experience, especially in the workplace: 
But in the work environment when I worked with a mixture of blacks and whites, the blacks always complained. Complain, complain, complain, (the black Americans I'm referring to) they always complained. They would associate any negative thing that happened, even if it was their own fault, with race. And I could have taken that both ways. I could have thought about it and maybe considered it. There were times when I felt I could understand this tendency because I felt that they had such strong beliefs based on how they had been brought up in a country with lots of racial prejudice especially in the time of Martin [Luther King Jr.] We never went through that. Well, maybe our ancestors did years and years ago when they were under the Massa-type [slave term for "Master"] thing, they could have talked about it. But I never was exposed to that in Jamaica. So coming here and hearing it from Afro-Americans-- Oh my God, they are very different.

Andrew and Patrice both allude to their Jamaican upbringing as the factor that explains both their critique of African Americans' sensitivity to racism and their refusal to adopt a similar attitude. For both, this observation reflects a very stark difference between the two countries' attitudes toward, but not necessarily histories of, race. Andrew's comment "We were not brought up in a racial society..." and Patrice's statement that "We never went through that" reflect heretofore mentioned--and likely idealized--memories of life in Jamaica as not focused on race, as even non-racial or post-racial. Regardless of how close to or far from they are to the truth, it is with these memories that participants confront the racial experiences they experience as blacks in America. These comments demonstrate, 
moreover, that respondents are aware that African Americans have largely had a different experience. Participants' criticisms of African Americans' preoccupation with race should therefore not be taken to mean that they deny the existence of racism in the U.S. As the next section shows, their own experiences preclude them from doing so. Encounters with Racialization and Racism

Participants discover the centrality of race in the U.S. in large part as a result of their experiences with various types of racial boundary-work here. The vast majority (in fact, 88 percent) of participants shared stories in which they or their family members had various types of racial experiences which ranged from relatively mild encounters with different types of racialization to outright racism.

Among the various types of racialization shared by participants were experiences in which assumptions were made about their abilities or skills based on the presumption that they were black. One of Albert's first such experiences occurred while he was attending a university in Boston. According to Albert, this well-known and highly ranked university is held in high acclaim in part for its sports teams, comprised of a large numbers of African American students who are awarded scholarships for the purposes of recruitment.

I went to [names of institutions have been deleted to protect interviewees' identities] College on an academic scholarship, but whenever I walked around off-campus in the town, people would say things like, "What's up Champ, how is it going this year?" "You're training hard?" Sometimes I'd even walk into places and they would give me free things. They assumed I was an athlete, and I was offended. Even though I was getting 
free things, I was offended because I was there on an academic scholarship, and they totally negated that by assuming that I was an athlete - because I'm black. I mean they assumed I'm black. I was highly offended.

Andrew, a twenty-seven year-old university graduate, had a similar encounter in Miami. For him the encounter was startling. I had asked what he had learned about race in the U.S. and Andrew insisted that the major difference between race in the U.S. and race in Jamaica, was that here it seemed race was so much more important (that is, part of daily discourse whereas in Jamaica this was not so). I asked Andrew to share an experience or encounter that illustrates what he was describing and he recounted the following:

In Jamaica, we used to swim in prep school and in high school I swam for the school team. One day while I was a university student in Miami, I was swimming in the university pool, and the [black] lifeguard came over to me and just stood up and was watching me. So I stopped and asked, "You know, is there a problem?" She responded, "No, I just, you know just, watching you swim." And I asked her why. And she said, "You're not American are you? You're not black American?" I asked "What you mean? Why? I'm, Jamaican". She's like, “Oh, because you can swim." And I was like "What?!?! What you mean?" And she's like, "Black people can't swim. Most black people can't swim. We don't have pools in the ghetto and we don't have access to pools to swim and pay for swimming lessons. We're not near the beach. So it's just amazing to see a black man swimming. Do you mind if I sit and watch?” And I was just 
like, "Suuure". And I kept swimming. And that was something that floored me. I would never in a million years have thought that was even possible.

The observer in this incident was African American. She had evidently been raised in a low income environment (she mentions the ghetto) in which access to certain resources and luxuries were limited. Her comment is therefore likely more a reflection of her own exposure and experience than the intentional assignment of negative stereotypes. This is not surprising given that the prolonged history of boundary-work around racial lines in the U.S. has resulted in a persistent relationship between class and race (Massey 2007). In other words, blacks and other minorities are, generally speaking, not likely to have had the same opportunities as whites. African Americans are often painfully aware of this fact, as this woman's comments demonstrate. Andrew, however, given his more privileged experience as a racially mixed middle-class Jamaican, may not have made this connection. For him the fact that his ability to swim had attracted such attention due only to the stereotypical belief that blacks cannot swim, was simply shocking.

Andrew, who phenotypically appears to be black, informed me that he had never thought of himself in racial terms when living in Jamaica. There, he said, he had never been asked to identify himself racially in formal situations (such as forms, applications etc.) Moreover, as has been pointed out, race is not perceived as being central to Jamaican society. He therefore identifies adamantly as "Jamaican" in this context and selects the racial category "black" on forms only if a racial category is absolutely required (that is, if an official insists that he must indicate a race.) Nevertheless, his reaction to this incident likely had little to do with the fact that he had been characterized 
differently from his self-conceptualizations, or even that he had been identified as black. He was simply responding to what he perceived as a negative and inaccurate stereotype. Other participants, however, find being characterized in the U.S. differently from their own self-characterizations, especially when coupled with the assumptions that are attached to such characterization, disturbing. Mixed-race Jamaicans' experiences vary based on their phenotypes; the assumptions made by people in the U.S. depend upon how the Jamaicans look to Americans. These are the building blocks of racial boundary work. A good example is 46-year-old Sean, who describes himself as Chinese, black, Indian and white because he was born to multiracial parents (he described his mother as Indian and black; his father Chinese and black; and his maternal grandfather as white.) Because of his physical appearance, Sean had always considered himself Chinese while in Jamaica. There, his self-conceptualization as Chinese had been affirmed by other Jamaicans as well. His first racial encounter in the U.S., however, dramatically impacted that self-characterization, "The day I landed, I was asked some questions at the airport because I was actually coming to stay. I was migrating. I hadn't visited. One of the [immigration] officers asked me, 'Race?' And I said, 'Chinese.' Immediately I was told very bluntly that I was black. So it was a wake-up call that first day I got here that hey, you're no longer what you think you are. This is a category that we're going to put you in."

For Sean, this experience of having his racial self-identification as Chinese refuted was clearly disconcerting. His reference to the experience as "wake up call" indicates his realization that he had entered a country with a different racial system. He realized that in this racial system he would not be viewed in the manner in which he had 
previously viewed himself. Caroline, whose encounter with race in the U.S was shared at the beginning of this chapter, describes below a similar experience as she waited in line to enroll at a local community college.

About 16 years ago, my sister and I were waiting in line to enroll at [name of institution suppressed.] A little white old lady was handling the forms. I handed her my form. I had put black in the section that asked about race. She handed me back my form and told me it was incorrect. And I asked, "What?" And she said "your race." And she crossed it [black] out. And I said, "No! I put the right thing!"

Caroline's encounter with racial characterization was different from Sean's in that while her identification on the form as "black" was challenged by this community college employee, it was Sean's non-black self-conceptualization (as Chinese) that was refuted. In both cases, however, the assumptions these officials made about their racial identities, were evidently made based on the respondent's physical features, and by the assumptions attached in this context to specific features.

These experiences of Sean and Caroline with racial characterization represent two clear trends that have emerged from the data: those participants whose phenotype bears any trace of black ancestry are automatically classified as black by observers from the U.S.; and those whose black ancestry is less visible (or not visible at all) are less likely to be so characterized as "black." That these trends emerged is not surprising since skin color has long been the sine qua non of racial identification in the U.S. Moreover it remains the case that any trace of black ancestry leads to characterization as "black." This documents the continued existence of the one-drop rule. Moreover, as participants learn, 
being characterized as black in the U.S. has important implications, one of which is greater vulnerability to racism.

In fact, a common complaint of those participants with visible black ancestry was about their various experiences with outright racism. As might be expected given the well-known correlation between gender and racism, men were more likely to report racist encounters than women. Of those participants who reported experiences with outright racism, 88 percent were men. One such male was tall, light-skinned Leighton whose facial features bespoke his black ancestry. Below, Leighton remembers one of his earliest experiences with racism which occurred while he worked at the airport in Miami:

My job in the airport was in customer service. So I remember walking through the airport and encountering a woman who clearly appeared to be lost. Although she was not a passenger on my airline I walked up to her and asked if I could be of any help. And she started talking and it became apparent that maybe she was a little bit drunk. So it caused me to ask more specific questions, "Gee are you trying to catch a flight? You just came off a flight? Are you looking for your bags?" But we were having some trouble communicating. Eventually the woman became frustrated and said, "You know what? Next time I'm going to ask a F-ing white person." For Leighton this experience was stupefying. It amazed him that someone who needed his help would respond to him in that manner based entirely on race, "I thought, how sad for this person! Here she is in need, and I'm trying to help her and ... she. . . Boy, she's messed up really badly! [laughing]" Though shocked, Leighton claims he was not offended. "I was surprised when I realized that this did not offend me. I mean, someone 
cusses at me, I should be offended. But it was like water off a duck's back. And I walked away from that experience actually feeling very good about myself."

Most participants, however, did not as walk away from such experiences unscathed. An example is 48-year-old multiracial Christine, the only female participant who reported an experience with outright racism. Christine, who considered herself both "brown" and privileged, in Jamaica, first encountered racism when she applied for a job at a restaurant in Kendall.

I thought I could be a waitress at this restaurant. I waited just about two hours after filling out the application form. Eventually a waitress very nicely said to me, "You're never going to get hired here. We don't hire blacks as waitresses here. You're wasting your time. And I thought I would just tell you that because you've been here for two hours." And so I went home completely bewildered and realizing for the first time, "Oh, I'm really black. And that really means something here."

As Christine's latter statement indicates, in addition to intensifying their awareness of the centrality of race in the U.S., experiences with outright racism evoked feelings of bewilderment in participants. As with Christine, these types of experiences have led to the realization that regardless of their own self-identifications, they are perceived as "black" in the U.S. Moreover they realize being "black" holds completely different meanings in this context. Garry, who had perceived himself as "Indian" while living in Jamaica, made a similar discovery when he encountered racism at the hands of a police officer in Miami. While Christine's encounter with the store clerk had occurred almost 30 years ago in the early 1980's, Garry's occurred much more recently. 
I remember one time, while I was attending [name of institution has been removed] and I was waiting for a friend of mine in the supermarket parking lot across the street from the university. I had the music playing and this Latino police officer came by and he just asked for my license and registration so I'm like "I'm parked. Can I ask why?" And he was like, "Listen nigger!" and he's like, "I'll rip my shirt and then hit you and then tell them that you attacked me first so just give me the license and registration." Honest to God, that's how he spoke. So yeah, so I have been classified as nigger here.

Through encounters such as this one (this was not the only encounter in which Garry was the victim of racial slurs) Garry came to understand that in this country he had been assigned a new and different racial identity - as "black" in the best of times and as "Nigger" in more hostile situations. More importantly, he realized that as someone who was perceived as "black" he was always going to be susceptible to racialization events such as this. When asked about the impact of these experiences Garry said, "It was a little bit of a shock you know. Initially, I must admit, I was upset. I even wanted to retaliate. But after you calm down, you know, you feel sorry for them. You pity them more than anything else."

The impact of these experiences is clear: participants react with shock, anger and consternation. These types of reactions have been well-documented by other scholars (Waters 1999, Foner 2001,Vickerman 2001) whose research has shown that black West Indians are generally astonished when they experience discrimination due to racism in the U.S. Yet experiences with racism have had another impact that is pertinent to this 
dissertation. Previous scholarship has focused on West Indians who are presumed in this context to be black. They have given little or no focused attention to racially mixed West Indians who may possess different racial self-conceptualizations. Black West Indians are shocked by racism; and they learn that being black might have severe consequences in this context. Mixed race Jamaicans learn similar lessons; but in the process their racial self-conceptualizations also change.

Biracial (black/Indian) Albert is among those respondents who reported that as a result of their racial experiences in the U.S. they have had a complete change in racial self-identification. Albert stated succinctly that having experienced racial profiling in stores, having experienced violent confrontation from white youth, he now considers himself "black" and while he did not do so at first, he now selects the racial category "black" on forms. The next chapter will address more in depth, participants' racial selfidentifications in the U.S. as well as the factors that explain their identification choices. I share this point here to emphasize that the impact of racist experiences on my participants was not just the realization that they were perceived as black. Rather, that perception and accompanying discrimination resulted in the adoption of a new racial identity. It is wellknown that racial identities are formed through a process of negotiation between individuals and those they interact with and/or make judgments about them. Scholars (Waters 1999, Omi and Winant 1994, Landale and Oropesa 2002) have shown for immigrants the process is also affected by specific contexts and locations. While my informants' experiences in Jamaica had in most cases formed their self-identifications as mixed, brown, Chinese, or Indian, racist experiences in the U.S. changed selfidentifications to black. 
Among participants reporting racial experiences were those whose exposure to such occurred through the experiences of family members including children. Participants with offspring were especially concerned about how racism had affected or might affect their children, sometimes much more so than how racism might affect their own lives. As Deborah told me, "I've had to deal with race in South Florida more so as a mother with my daughter going through the school system than I have had to deal with it personally. For example, while she was in kindergarten, having a white male child say to her that he doesn't play with brown people.” Caroline and Althea shared similar concerns about their teenage sons. In their cases the concerns were mainly that as young men they were likely to be subject to racial profiling. Caroline said, "I think about race in regards to my children more so than myself." I asked her to explain and she said, "Well my son is going to be 16 and if he stays out past his curfew my mind is already racing towards thoughts about if he's ok, if the police have stopped him." Althea's concerns have grown in part out of stories told to her by people at her church about the experiences of their young, black sons. But they have also arisen as a result of her son's actual experiences and his reactions to them. She shares one below:

The other day he went to the mall with some of his friends, both white and black, and the police said to them, "You can't walk in such a big group. You have to walk in groups of four." They don't allow so many, all eight of them to hang together. And he came back and he said, "Oh, mom, these police are prejudiced." I said, "Maybe, they weren’t being prejudiced. They just didn't want a big group of teenagers walking together." But, he's so aware of the racism here. 
Despite her uncertainty that the policeman's behavior had in fact been motivated by racism, Althea was moved by her son's reaction to the incident. Parents like Althea and Caroline agonize over finding ways of protecting their children from experiences such as these. Aware of the stigma that is attached to blackness in the U.S. they search for ways made to avoid that stigma and thereby keep their children safe. They make efforts to teach them how to dress and behave in ways that might distinguish them as wellbehaved children. As Caroline put it:

I think we feel that we have to do better than anybody else. So we push our children because we don't want them to be at a disadvantage here because they are black. So we let them know that they have to do well in school; they have to get straight A's; they have to behave themselves. They have to be careful on the street. Especially the boys.

While virtually all participants reported racial experiences (either their own or those of family members), their experiences varied based on their appearance (phenotype) and gender. As mentioned before, far more male than female participants reported racist experiences. Darker skinned men were more likely to report outright experiences with racism and racial slurs. Light-skinned men whose facial features did not make their black ancestry obvious had completely different experiences. Some of them were presumed to be Hispanic - since they did not appear to be completely white either.

Thus, as participants experience racial boundary-work, they come to learn, by experience, about the centrality of race in the U.S. And through their interaction with African Americans, participants become aware race holds particular salience for people of color. For the majority who find that, based on their skin color and/or facial features 
they are characterized as black in this country, the lesson includes discovering the meaning of being black in the U.S. Even the 20 percent of participants who had considered themselves black in Jamaica were startled by this discovery. The following sub-section examines comments from participants about what they learn it means to be black in America.

\section{Being Bounded as "Black" in America}

Norman, a 46-year-old dark-skinned biracial male has lived in the U.S. for over 20 years. While aware of his racially mixed ancestry, he had always identified as black even in Jamaica and continues to do so in the U.S. Norman bemoans the relative value assigned race in the U.S., noting in particular, specific assumptions that are made about people of various races that demean and derogate people of black ancestry:

They assign more value to [race] here in the U.S., value in that a person who is white is deemed to be less of a public threat, is seen as smarter, is seen as more enlightened, is seen to be even more civil. In contrast, a person who is black is perceived as less educated, potentially violent, not industrious, and lazy.

For Norman, the "value" that is assigned to race in the U.S. is about rigid parameters that are drawn around racial groups and assign specific skills and behavior patterns to each race. Negative stereotypes are attached to minorities (especially blacks); more positive ones are attached to the whites. Thus Norman learns that to be black in America is to be automatically perceived as naturally inferior and to therefore be treated accordingly. Opportunities are assigned or withheld based on race; blacks are not 
necessarily treated fairly or politely in public spaces or in business transactions. He cites examples below:

Well, the classic example is I am walking on the street and a woman who sees me approaching will cross over to the other side of the road or maybe clutch her handbag [purse] a little bit tighter. Or even in terms of how people relate to you sometimes during a business transaction: the level of service, you feel, (sometimes this might not be justified, you know, this might be simply be a person delivering poor service, or being impolite in general) but sometimes I've noticed that even when you're being served you wouldn't, as a person of color, get the same level of politeness and courtesy that others would. Or when you go into stores sometimes store employees would kind of monitor you. And you're conscious of that. Of course that might be the job function you know, so, but I was acutely aware of those situations.

Damian, a 38-year-old biracial (Chinese/black) male participant shared similar sentiments. Speaking of how blacks are viewed in the U.S. he said:

Of course they are viewed differently. It's inherent for people in this country to automatically downgrade someone who appears to be black without even hearing them speak, or seeing what they're capable of doing. If you had a whole bunch of people in a room lined up for a specific task or role and they were all wearing the same thing (say they're all wearing a white smock) you would naturally not want to select a black person. And that's the impression I got. 
Regardless of how participants view themselves racially their realization that being black or being perceived as black in the U.S. is accompanied by negative social stigma, and the knowledge that blacks are still likely to be subject to discrimination, are disturbing. While this is especially so for those lighter-skinned participants with memories of a privilege in Jamaica, participants like Norman with darker complexions find this difference just as unnerving. Experiences such as being followed around in a store or being avoided simply based on one's race, while quite common occurrences for black males in the U.S., are unheard of in Jamaica. As Kevin (multiracial: black, white, Indian) put it, "I guess black people, people of darker-skinned color going into stores and being followed around and questioned was just something that I wasn't used to. I really didn't expect that coming from Jamaica, you know, because everybody treats you pretty much the same."

Participants also said that since their migration they had learned that it is dangerous to be black in the U.S. Below, 48-year-old biracial Christine, describes Arthur McDuffie's story as the incident that brought that realization home to her. McDuffie was a black insurance executive who was beaten to death by four City of Miami police officers in 1979 (Dunn 1997). According to Christine, she was hardly aware of race until this incident occurred. It was then that she realized not only that she was black, but also that being black had implications for her safety.

The greatest thing that happened in the U.S. that changed my perception of myself is the murder of Arthur McDuffie. I had just come to the United States from Jamaica and knew nothing of race, racial identity. I certainly didn't know that I was black and what that meant; I didn't know the 
history of the struggle of African Americans; I didn't know very much about Martin Luther King and Malcolm X and Angela Davis, or Thurgood Marshall. And so I was a sponge, soaking up everything about this culture at that point.

When asked how the McDuffie incident had affected her, she said:

It changed my perception of myself because I realized that I could be in danger. I could have no rights. The police officers were acquitted. They were never found guilty. The city government's only compromise was to create a Community Relations Board to help promote blacks throughout the system. So the barriers were still in place, but that was what came out of it. And it just brought home to me for the first time that this is a dangerous county. And so I became politically active then.

Thus far I have argued that participants' encounters with an unfamiliar racial system have been disconcerting largely because they are so different. As they have become aware of the centrality of race in the U.S., participants have developed a much more heightened awareness of race than they had held in Jamaica. They are discovering that in this context, the one-drop rule draws bright boundaries around them, cutting them off from the mainstream and all its additional opportunities. The one-drop rule singularly—-regardless of social class, education, etc.--determines their social location. Thus, as some discover that in this country they are perceived as black, they also learn that black phenotype makes them subject to racism rather than just racialization. Participants learn that "black" is not just a label; it is the lowest rung on a very rigid social hierarchy. The latter realization is especially difficult to accept given the relatively 
privileged experience that characterized the lives of most participants while in Jamaica. They were privileged because they were of mixed ancestry but in the U.S. the one-drop rule pushes them down to the bottom. What my participants are describing in this section is their encounter with what Omi and Winant (1994) refer to as the "social meaning" of race - a social meaning that is unique to the U.S. and that they believe is not like that of their home country. The social meanings of race in the U.S. have historically been limited to the political, cultural, or economic arenas of life, but have had implications for each of these lived experiences (Omi and Winant 1994). In their experiences with racism and racialization they learn about these social meanings. They learn, however, from the perspective of racially mixed Jamaicans whose experiences in the home country afforded them relative flexibility and mobility, and in most cases, privilege.

Yet it is important to note that what is different for my participants is not that race holds meaning in the U.S. context. As pointed out in the last chapter, even while denying that race held social significance in Jamaica participants' stories reflected racial consciousness even among themselves. What they perceive as different is the intensity with which race works in the U.S. compared to Jamaica. This reaction is not an unusual one for immigrants as previous scholarship has shown quite clearly. But as racially mixed immigrants their comments reflect concerns that have not really been addressed by previous studies. The next section explores one of the major concerns of a group with memories of racial fluidity who encounter greater rigidity, and what they recognize to be two separate worlds. 


\section{Boundary Maintenance: "Two Worlds"}

At the time of her interview, 27-year-old Tracy had lived in the U.S. for 9 years. She described her mother as "mixed with Thai, German and Chinese" and her father as "predominantly black, Indian and Scottish.” As I had done with other respondents, I studied Tracy's features. In my estimation she was not very light-skinned by Jamaican standards. But her long, straight, dark-brown hair and ambiguous facial features certainly would have marked her as not (just) black in Jamaica. When I asked about her experiences with race in the U.S. Tracy told me, "I don't think they view race anywhere similar to how they view race in Jamaica. I think the categories here are much more defined. The need to put you in one box and not to think that you're in between both is much stronger here than it is in Jamaica."

Tracy's recognition of the existence of "more defined" racial categories in the U.S. reflected a major theme among participants. Through their encounters with racialization and racism in the U.S. they have come to perceive racial categories that are more rigid when compared to those they had left in Jamaica. As the last chapter indicated, participants remember a Jamaica in which racial mixing was not unusual, and racial mixtures were accepted, even idealized. It seemed to participants like Tracy that this was not so in the U.S. Thus Tracy's observations reflect a clash of racial worldviews. Her worldview, formed within an environment in which boundaries are blurry; and that of the U.S. constructed in a situation in which boundaries are bright. The former permit liminality; the latter do not. 
Multiracial Andrew gave also pointed to rigid racial categories when I asked him to share his impressions of race in the U.S. His response was particularly interesting as he referred to reliance, in the U.S., on census categories:

I'd say that in the States the first thing they look at is black, white, Hispanic, they automatically categorize you the way that the census is categorized. In Jamaica the first thing they look at is your shade of color, what grade are you. Are you really a black man or are you a brown man? Are you yellow? Chiney? [Chinese] That's the sort of thing we look at. We look at shades, and Americans look at specific races. (Andrew, 27, multiracial: black, white, Chinese, Indian)

It is not clear to me whether participants were aware of the role of the Census Bureau in creating and monitoring racial categories and the collection of racial data. Andrew was the only interviewee to actually mention the census. It was clear, however, that all had encountered these categories on formal documents (immigration forms, job applications, college or school enrollment forms, and so on). And the fact that in the U.S. both public and private agencies collect such information proved disconcerting for these racially mixed Jamaicans who do not recall having to define themselves racially in formal situations in Jamaica. As one female focus group participant put it, "That was my major difficulty--having to define my race because I had to--not because I particularly wanted to."

It seems evident from this respondent's comment that participants' discomfort goes beyond the requirement to define oneself racially. For one thing, as has been noted, these Jamaicans are accustomed to conversations on the island in which questions are 
asked or comments are made about their racial ancestry. There are two crucial differences, however. In the first place, while in the U.S. racial identity translates directly into social status, this was not the case in Jamaica. In the second place, Jamaican society permits fluidity in racial identification. In the U.S. context, however, and as evidenced in this chapter, Jamaicans are forced to utilize the five racial categories established by the Office of Management and Budget in 1977. Although for the first time in U.S. history the 2000 census permitted the selection of more than one racial category, various racial and ethnic organizations representing multiracial Americans, Arab Americans, and others, continue to believe that the current categories are restrictive. As such they have argued that the categories do represent their self-identifications and have therefore lobbied for the inclusion of other categories on the census (Nobles 2000). Female focus group participant Jacqueline and others share similar concerns. One of the primary reasons for which Jacqueline finds it difficult to complete forms that collect racial data is that, in her view, there is no category on these forms that reflects her own racial selfconceptualization. As she put it, "I found myself having to define my race and I was at a loss about what I was. Ok, so what am I? I just wasn't sure. And of course they didn't have a mixed race box, right?"

Similar concerns were shared by interviewees of various racial mixtures. Twentyfour-year-old Denise, who describes her mother as Chinese and black, and her father as Indian, expressed her frustration and discomfort at being forced to select a particular race:

Whatever racial boxes they ask you to select, since I'm mixed, I always have a lot of problems. If there isn't a "mixed" or "other" box, I don't know what to select. Sometimes I just leave it out. And I think it's unfair 
for people who are mixed to have to choose between whether they're black, white or Chinese, or pink, or purple or whatever.

For study participants, this emphasis on racial categories which they encounter in the U.S. goes beyond mere collection of racial data. They feel that U.S society is divided into two worlds: a black world, and a white world. Damian put it this way, "Now we're in America, and we're talking about 'black' and 'white.' There's the 'white world' and there's the 'black world,' period." Although no one actually used the term, they are in fact recognizing the U.S. racial binary system which though continually challenged by racial intermarriage and migration from non-European sources continues to influence racial thinking in this context. And as has been noted by previous scholarship on the experience of multiracial Americans (Davis 1991, Root 2001, Spickard 1989, Zack 1993) the rigid divide between these two worlds does not permit liminality or "inbetweenness" like the mixed categories permitted in Jamaica. Thus, my informants tell me that, unlike their experience at home in which their racially mixed background was celebrated, and as Damian indicates above, they feel great social pressure in the U.S. to choose one "world" or another. That pressure comes in part from the feeling that in the U.S. a racially mixed individual is not completely accepted by either racial group and as Michael shares below, this is an unfamiliar experience - one they claim never to have had in Jamaica.

You're not really accepted by whatever group of people you're mixed with. Because black people don't really see you as black and white people definitely don't see you as white. So, sometimes you are left to find your own people. Whereas in Jamaica if you're mixed you can still have friends and still be an integral part of society. It's not an exclusionary 
characteristic. (Michael, 26, multiracial: black, white, Indian, Chinese; 6 years in the U.S.)

Damian told me that he became aware of the existence of "two worlds" partly through stories from his wife's childhood. A second-generation Jamaican immigrant, his wife is biracial with Jewish and black ancestry. He tells of her complaints that she was never fully accepted by either of the "worlds" to which she had been exposed while she grew up in the U.S.

Here's where she had problems. She was light-skinned, and as per standards she had good hair. So when she was in school, she wanted to hang out with the Jamaicans because her parents were Jamaican. By all means, since her father used to play loud reggae music all day and all night in the house, she was Jamaican. But the Jamaican kids would not accept her. Neither would the black American kids.

“Why wouldn't the Jamaican kids accept her?” I asked. He replied, “Because they'd say she's a Yankee." "So why didn't the black American kids accept her?" I followed. And he replied, "Because she's light."

Experiences such as that described by Damian's wife are not uncommon for multiracial Americans. One such story is cited in the introduction to this dissertation. Racially mixed Jamaicans insisted, however, that because a majority of the Jamaican population has black ancestry and thus most are racially mixed, it is easier to "have friends" and "be an integral part of society" there. As Michael put it, the sharp divisions among racial groups which they encounter in the U.S.-- particularly the ways in which those divisions are expressed in daily experiences of exclusion--are startling. Thus 
participants take note of and react to the rigid racial lines that have been constructed and maintained in the U.S. and compare them to their memories of relative fluidity in Jamaica. And they note the existence of two worlds (black and white) and the boundarywork performed by members of both worlds make to ensure that they remain separate and distinct.

Despite rising rates of interracial marriage and a growing multiracial population, it seems that in the minds of most Americans, there is still no room for crossing racial lines. In other words and even in a racially complex context such as South Florida—as I shall discuss shortly—for people of African ancestry the one-drop rule still rules. Jamaican immigrants find that there is little to no room for racial liminality in the U.S. and in stark contrast to Jamaica. Karlene, who like most participants, believes that to be racially mixed is not really acceptable in the U.S. summarizes this observation:

In Jamaica even though you know we have the classism and the fact that people talk about the 'browning' and the 'coolie', I think that due to our motto, "out of many one people" we understand that we have come from different backgrounds. So people are more comfortable with that. And here because of the slavery and the stupidity that carried on up here, people are not as comfortable really with somebody being a product of two different races. (Karlene, 26, multiracial: black, white, Indian; 4 years in the U.S.)

Biracial (Chinese/black) Damian shares similar views:

Jamaican people can identify with mixed people by their familiarity with their parents and the characteristics of a mixed person. Here they don't 
know what the hell I am. They're not quite sure if I'm black, but I've been identified as Filipino, Chinese, Spanish, Polynesian. Most people think I'm from Hawaii. But when I go back to Jamaica [and walk by] a strange man on the street (I don't even know him) will say, "Whappen Mr.

Chin" [What's up Mr. Chin?] because he knows just by looking on me that I have Chinese background. That's because Jamaican people have more exposure to mixed races.

Given the fact that Karlene and Damian are among respondents whose mixed racial ancestry was noticed by classmates, friends, and others in Jamaica, their keen sense of this difference in perceptions about racial mixtures might be expected. One might also expect participants whose mixed race ancestry is not as visible, to be less aware of such differences. Yet my data clearly indicate that this is not the case as even dark-skinned participants who identified as "black" in Jamaica held similar perspectives. One such individual is Norman, who phenotpyically appeared black to me and who spoke of the relative acceptance of racial mixtures in Jamaica, "Well, in Jamaica I think we can really see people there and know that this person is mixed. We don't necessarily just see them as just a black person." And he refers to the tendency noted in the U.S. to emphasize placing people into a specific racial category as the "bright-line rule, where you're eitheror."

Norman goes on to explain that in the Jamaican context it's one's non-black ancestry that is recognized. Black, not white, is the unmarked category to which other categories implicitly refer. "We can say for example that a person is 'half-Chiney,' or 'half-Indian.' We recognize that other genetic component of the person, that racial 
component, without necessarily assigning a value. But we do recognize it." Norman is here pointing to a key difference between the two racial systems that is noted by participants. The fact that most Jamaicans are black renders one's black ancestry commonplace. Moreover, the persistence of pejorative notions about blackness and of the idealization of non-black ancestry makes it much more likely that that the latter will be emphasized in Jamaica's racial system.

Thus, unlike their descriptions of Jamaica as a society in which racial boundaries are permeable owing to class and the Jamaican national identity as exemplified by the motto "Out of many, one people," participants describe experiences in the U.S. that point to rigid boundaries that have been constructed specifically to divide the races (especially blacks and whites). Participants note how these boundaries are carefully patrolled and are thus largely impermeable in the minds of most Americans. Therefore, in terms of racial identification, there is little or no room for multiple identities or for "in-betweenness." Moreover, as Tracy's comment (at the beginning of this section) shows, to be "inbetween" is permitted, even valued in Jamaica, while in the U.S. this is not the case (Daniel 2004, Root 2001, Williams 1996, Williams 2006, Zack 1995). Scholars studying multiracial Americans argue that there has been and continues to be little to no space in the American racial system for multiracial or mixed identity (Root 2001, Zack 1995). It is just this very issue that the multiracial movement set out to counter in their quest for a “multiracial" category on census forms (Daniels 2004, Williams 2006). In her discussion of "what are you?" encounters (that is, encounters in which their racial identity is questioned) of biracial Americans, Williams (1996) argues that in the U.S. deeply ingrained beliefs in distinct monoracial and pure "races" are overwhelmingly 
fundamental to this highly racialized society. Multiracial individuals challenge assumptions of fixed and separate racial categories as "what are you?" encounters demonstrate.

Comments from participants highlighted their belief that while in Jamaica being racially mixed was considered to be "normal" (for some participants, being racially mixed is the norm since although this may not be the case, they believe that everyone in Jamaica is racially mixed) this is not so in the U.S. For participants, the existence in the U.S. of bright, rigid and carefully patrolled racial boundaries fits hand in glove with an apparent discomfort with racial mixtures. For them the existence of rigid racial boundaries has been especially disconcerting when they consider the more fluid situation in Jamaica. It is not that racial categories do not exist in their home country; it is that it is much more possible to cross those boundaries and to cross back as well. That is, the categories are permeable and flexible as against much greater experienced rigidity in the U.S.

In this chapter so far, there have been various voices from Jamaicans of mixed ancestry who encounter rigidity in race categories and fierce racialization in the U.S. But they are actually expressing these experiences in South Florida, one of the most diverse regions of the United States. The population of South Florida, Miami-Dade County in particular, is ahead of the country in terms of profound demographic shifts largely owing to immigration. South Florida is much more Hispanic (Miami-Dade County is 57 percent Hispanic and Broward County, 17 percent Hispanic) and much more black (21 percent in 
both Miami-Dade and Broward counties ${ }^{19}$ versus 13 percent on average) than most other regions. The black and Hispanic populations in all three counties (Miami-Dade, Broward and Palm Beach) together comprise 49.8 percent of the total population. Therefore, it makes sense to expect that racial boundaries and racial boundary work would be different in South Florida than in other areas. So far the data presented do not support this supposition; the one-drop rule seems as enforced in this region as in regions without so many Hispanics and other peoples who phenotypically can be situated between the poles of black and white. But the issue of context merits greater attention and I turn to that now.

\section{South Florida: Three Worlds?}

While few of the participants in my study addressed the particular South Florida context as they described their racial experiences, the fact that any comments were made about the peculiarities of this region grabbed my attention. Multiracial Susan (Chinese, White and black) is among those who noted regional differences when asked her opinion about the ways in which Americans versus Jamaicans view race, "It depends, because an American from South Florida is very different from an American you'd find in Kansas." I asked her to explain this statement and she continued:

I really don't think that Americans from South Florida have a problem with race. I mean they've been exposed to diversity. There are a lot of black Americans and Caribbean blacks here and lots of Hispanics too.

Every now and then you come across a Chinese person or a white person.

\footnotetext{
${ }^{19}$ U.S. Census 2000
} 
So I think that they really don't think about it too much. I think that Spanish people [Hispanics] are different too because it depends on what part of the Americas they come from. Because in Cuba there are a lot of Afro-blacks or Afro-Cubans there.

In Susan's estimation, the dominant Hispanic population in South Florida coupled with the presence of blacks and other racial groups from the U.S. and elsewhere provides South Floridians with exposure to various races and ethnicities, and affords them less intense experiences with race or racism. She believes that it is for this reason (that is, not having personally had negative racial experiences) that she has not thought very much about race here. Biracial (black/white) Deborah shared similar views when I asked about conversations she may have had with friends about race:

I think one of the challenges in South Florida is that because South Florida tends to be so multi-ethnic and multi-racial the ways in which race gets framed are a little bit different than it gets framed in the northeast, at least from my experiences. So I would have probably had more, and again it was a different time too, but those of my friends who are both African American and Caribbean who lived in New York, or New Jersey, or Philly (my entire family is in Philly), the discussion around race and racial difference and prejudice and dealing with discrimination and so on tends to be far more frequent than I think is the case in South Florida.

Thus for these participants, the multiracial make-up of South Florida creates possibilities for more peaceful coexistence and, perhaps, even tolerance of different races. Both individuals claim to have been exposed to less severe racial experiences in South Florida 
than might be expected elsewhere or than their relatives and friends have had in other regions. The region's demographic make-up thus suggests possibilities for experiences that perhaps include greater fluidity in racial identities and might even produce in the future a post-racial environment. And the experiences of some- - but certainly not all-participants as far as racial characterization by others in South Florida suggest that this may be so. Multiracial (Chinese, white and black) Justin, observes that he is often viewed as "Hispanic" in Miami, according to him, because he's "mixed." I can clearly see Asian ancestry, but the operative issue here is that he is racially mixed, and in Miami "mixed" often becomes conflated as "Hispanic":

In Jamaica, in a lot of ways you're either black or you're not. And the "not" means white. That was my experience there. Here. . Well Miami is a bad example; but this is where I came. Even though I didn't think of myself as white that's what I was classified as in Jamaica. It never ever felt that way here because I clearly am not white here. That's not to say that I necessarily think of myself as black. I know what I look like [Chinese] but I don't interact that way. A lot of people assume that I'm Hispanic because I'm mixed and I do speak a little Spanish. But here the difference is really I'm not white even though I already knew that. You understand what I'm saying? But Miami is not representative of America. Justin clearly realizes that his experiences are due to the context in which he lives. He repeatedly states that Miami is not representative of the nation as a whole. Justin is not the only participant to have been characterized as "Hispanic." Multiracial (black, Chinese, Indian) Denise shares her frustration at her "race" not being recognized and at 
South Floridians' surprise when they discover that she is not from the Dominican Republic or Cuba, but Jamaica. And when asked about his early racial experiences in the U.S., multiracial (black, white, Indian) Garry replied, "White people, well, I am sometimes considered Hispanic. I guess people assume that I am Hispanic. So I go with that."

The point here is that Justin and Denise demonstrate awareness of how South Florida is different as a region in terms of racial experiences and racial identifications. Justin continues by saying, "People from Jacksonville, people in Atlanta, people in the Midwest still think about race, don't like black don't like colored people. So there's still a lot of that in the U.S. But not so much here [in South Florida] where it's so racially mixed." It is not clear exactly how he knows about how people live and experience race in other parts of Florida (Jacksonville) and other states or regions, but he shows that he is aware that the multiracial make up of the South Florida region permits fewer racial confrontations and greater fluidity as far as racial characterization.

Despite these comments by several interviewees, the evidence still weighs much more heavily on continued racialization and racism in South Florida than on the side of great openness to mixtures. In their own stories, in fact, participants identify ways in which they have experienced boundary-work at the hands of Hispanic South Floridians. Various examples were given above, although I did not identify them explicitly as boundary-work. Among them was Spanish language use in public spaces as biracial (black/white) Patrice explains:

I recall an incident that happened not so long ago in the office. As I mentioned before the office is predominantly Spanish [Hispanic]. The top 
surgeon is Spanish, and all his employees or people that he employed were Spanish. I only got that job because Dr. Smith [pseudonym] moved and wanted me there. So that day a white person came into the office and while she was there, as they always do, they were all speaking Spanish. I had had a struggle because I had wanted for some time to tell them not to speak Spanish if someone is around who does not speak Spanish. But the opportunity had never come up before then. I had also wanted to avoid offending them. But on that day this patient came in and they assumed that she didn't understand Spanish. They said something rude about her, and she left crying. Her mom called and asked to speak to the office manager and she told me everything. So I finally got my chance. I went out there and I addressed the problem. I told them, "You know, we live in the U.S. and in this country the main language is English. Spanish is the language that makes you comfortable. I don't have a problem with you speaking Spanish. But don't assume that everybody around understands what you're saying. If I don't speak Spanish, and if every time I approach you're speaking Spanish, I might think that you're talking about me.” I told them, "It's very rude." And then I qualified what I said based on the report I got from the patient. So now they say, “Patrice is coming. Don't speak Spanish.”

I had asked Patrice about how, if at all, people talk about race at her workplace. That her response was about Spanish language use was revealing. In choosing this example, Patrice showed how, intentionally or not, boundaries were being drawn, through the use 
of a language, to exclude those who do not speak it. In this case, she was able to take advantage of an incident of professional misconduct to make her point. But she makes it clear that she had long since objected to Spanish being used in large part because she felt excluded by the act. In fact, the entire story reveals a general feeling of discontent at Hispanic dominance in her workplace. She suggests that the chief surgeon who is Hispanic intentionally hires only Hispanic staff. Her own employment had been possible only because of the efforts of her (black) boss for whom she had worked elsewhere prior to taking this job.

Another example of boundary-work by Hispanics, expressed by participants, involved concerns about hiring practices that favored Hispanic employees over others. Twenty-four year-old multiracial (black/white/Indian/Chinese) told me, "Because of the racial composition in South Florida, Hispanic people tend to be in a better position than other races. And as a result the hiring practices are very discriminatory. So once you get the first Hispanic boss you notice that all the other promotions tend to be Hispanic too." Another example of perceived boundary-work on the part of Hispanics was provided by multiracial (black, Chinese, Indian) Denise. Although she had been mistaken as Hispanic by some South Floridians, Denise expressed frustration at her Hispanic boyfriend's characterization of her as 'black' - a characterization with which she could not identify:

I had a Hispanic boyfriend, I was actually surprised when we started going out and he said that he considered me black, and I was like: Excuse me! Which part of me is black? Do you need to fix your glasses? Do I look black to you? And he said, "Yeah, you're black." And I said, "So why do 
you say that I am black?" But he looked at my brother, who is a little bit lighter than me and looked more Chinese, he wouldn't call my brother black, but he would call me black. And it was something that caused a lot of tension between us and that was a large part of the reason for us breaking up. And he just said, “Well I couldn't really tell what you were, so I just call you black.” And the same thing, we actually had another argument with his family. His family called me black. I was actually very offended and I got into an argument with his family and they said, "Oh, you still going out with that black girl?" and he came back and told me, and I was. . .up to this day, I'm still a little upset about it. But I was just so surprised that I could look [emphasis mine] Hispanic, but because I'm not Hispanic and I don't speak Spanish, and they don't really know what I look like, they just call me "black."

I studied Denise as she shared this story. In my estimation, she is light-skinned by Jamaican standards. It seemed to me that her long straight hair (which she explained to me was really curly but had been straightened by chemical crèmes) and her facial features which lacked visible African or Chinese characteristics, would likely lead to characterization in South Florida as Hispanic. Moreover, in Jamaica, she had been characterized as Indian, Chinese, or "brown" but likely not generally as black. Denise's experience with her boyfriend and his family was unpleasant not only because of their racial characterization of her as black but also because of the boundary she felt he and his family were drawing by excluding her from the possibility of Hispanic identification. The fact that their characterization of her as black was at least in part responsible for the 
demise of their relationship demonstrates the importance that being placed in that racial category held for her. It is also apparent that she believed they held negative impressions of blacks. The statement "you still going out with that black girl?" in addition to demonstrating the ongoing potency of the one-drop rule, suggests a degree not only of racialization and boundary-work but also of not very veiled rejection on their part. It also seems important that she points to the discrepancy between how she is perceived "I could look Hispanic" and how she is received "They just call me black." It indicates that her expectation is that she will be characterized based on her physical appearance. Of course, given that this young man was her boyfriend, it is also likely that being excluded from Hispanic identification was much more personal for her than it might have been had the characterization come from individuals who were less important to her.

Other examples of boundary-work by Hispanics included outright racism. One such case is that already-cited experience of Albert who recounted an incident of police harassment in Miami. Albert described the police officer as Hispanic. Albert's comments about Hispanics in fact revealed a degree of resentment:

I think that Hispanics, although they're numerically the majority at the school, I think they want to be perceived as a minority. So they're constantly trying to juice that, you know, to get some leverage from that. My teachers, though, are all from different places. I have some teachers from Africa, from Asia, and so on. For the most part, I don't feel any racial tension from them. But the Hispanic ones, I feel it. They talk to me differently. They mark my paper differently. I have to really fight with them. 
In accusing Hispanics of wanting to take advantage of minority benefits despite their numerical dominance, Albert is expressing his distrust of members of this community. He feels that Hispanic professors evaluate his work "differently" and shares that he has had to confront them. Although he provides no evidence to support his accusation, it is clear that he feels particularly threatened by this group.

Although there were relatively few comments that focused on South Florida as a region, that participants recognized this difference at all is significant and needs to be addressed. The study did not set out initially to examine this factor. But as it has emerged from the data, it is worthy of mention. The importance of such comments lies in the degree to which they demonstrate that mixed-race Jamaicans understand the U.S. racial system as divided into two worlds nationwide, but into three worlds in the South Florida context. As one male participant points out, in the South Florida context there are three palpably different racial worlds: the white, the black, and the Hispanic:

Now we're in America, and we're talking about black and white. There's the white world and there's the black world. Period. South Florida there's also a Hispanic world. And as far as the media is concerned I think there's a clear separation of those three things here in South Florida. I think being somebody who's mixed or from another culture you have to kind of identify with one of those three. (Damian, 37, biracial: black, Chinese)

I have argued that through their various racializing and racist encounters my respondents discover that in the U.S., and even in multicultural Miami, race functions as a bright boundary that separates groups and determines their locations in the social hierarchy. As such, most find that their black ancestry locates them in the lowest rung of 
that hierarchy. They discover moreover, that liminality is not permitted in this more rigid racial system. They are not permitted to be mixed, but must be rigidly categorized. These facts are difficult for them to accept given their more fluid experience with blurred boundaries in Jamaica. When boundaries are blurred groups are permitted simultaneous locations on either side of the line of demarcation. Thus these racially mixed Jamaicans their and that they hold memories of privilege in their home country.

\section{Theoretical Discussion}

The racial experiences of my interviewees demonstrate how people living in the U.S., regardless of how deeply or shallowly rooted, consciously or not, are constantly engaging in boundary-work in order to preserve the racial categories and the borders between them that have been erected historically in the U.S. The study participants' expressions of surprise, consternation, and anxiety reflect their realization that in these experiences with racism and racialization as well as racial categories, people draw boundaries around them that enforce American (not Jamaican) racial characterizations. These characterizations assign specific value and meanings and that exclude them from membership the mainstream of America society, regardless of socio-economic status, and this fact is particularly disturbing for participants.

I have already pointed out that the work of erecting and maintaining boundaries results simultaneously in feelings of similarity and difference - people are at once included by the creation of communities, and excluded by being cast as the "other." Boundaries also serve as means of defining one's identity as exemplified by the U.S. racial dichotomy guided by the one-drop rule. Moreover, boundaries are the foundation to 
the overlay of social status. If there are no internal fracture lines to a group there can be no social strata; similarly if peoples are not differentiated first (us/them at a minimum), there can be no superior and inferior groups. In both the U.S. and Jamaica, the demand for cheap labor and the "convenience" of the arrival of cheap labor that appeared physically different than the landowners_-black slaves_-became the building blocks for race boundaries which then served the purposes of social rankings, except except under slavery these rankings not only became permanent for life, they also were passed down from generation to generation. Since their invention, racial boundaries have been used in both countries to assign people to specific locations within their stratification systems. They have become divisions that make inequality seem "natural."

The primary focus of this discussion is, however, on the boundary-work that ensures the continuation of social boundaries. Boundary-work has proved a useful theoretical framework for explaining the social construction of rigid racial boundaries that occurred under slavery in both territories. It also explains border-patrolling (boundary maintenance and fortification) that still characterizes race relations in the U.S. Caroline encountered border-patrolling when her husband was accused by an African American woman of not marrying his "own kind." Boundary-work is, in fact, what my participants encounter through their various experiences with racialization, racism, and rigid racial categories. As the next chapter will show, it is also what they do as they begin to participate unawares in creation of new boundaries.

As indicated in the introduction, scholars ascribe boundary-work to the human propensity for categorizing (Massey 2007, Sibley 1995). According to Sibley (1995) categories become so important that the inability, for any reason, to place things into 
separate, discrete categories, leads to great discomfort. That is, anything that cannot be easily categorized creates a type of social problem, crisis even. This very point was made by anthropologist Mary Douglas, who long ago identified the problems societies "feel" when they encounter liminal, middle, indeterminate items that cannot easily be categorized. Certainly, racially mixed people represent a middle racial ground that disturbs nicely bounded categories. The one-drop rule in the U.S. has operated long and hard to handle this unsettling ambiguity; but as the U.S. population incorporates more and more people who cannot be fit neatly into the black catchall category, the rule, though still operative as this dissertation clearly shows, has weakened.

It is not categorization per se that causes so much difficulty, nor is it even the indeterminate situations, the ones that are hard to fit into the categories. Rather, it is the second aspect of categorization in human societies - the assignment of social significance to categories through varied statuses - that drives boundary work's importance. In his work on stratification in the United States, Douglas Massey (2007) demonstrates how social inequality based on race has been organized and maintained through boundarywork even long after many overtly racist aspects of this work have been eradicatedslavery, lynchings, anti-miscegenation laws, etc. Arguing that white Americans have seen to the development of categorical inequality through mechanisms that are based on two basic strategies: "exploitation" and "opportunity hoarding," Massey traces the history of social stratification based on racial categories in the U.S. in pre-and-post-Civil Rights eras. He argues, for example, that New Deal legislation was crafted to ensure exclusion of blacks from coverage and he outlines efforts to dilute post-civil rights legislation in 
order to preserve white privilege. Such efforts have been particularly evident in persistent and deliberate stratification in the housing market.

Importantly, Massey also points out that the attitudes of many white Americans toward people of color (that is, all those deemed non-whites) continue to reflect negative and derogatory stereotypes. While many white Americans have abandoned conscious support for racism, he writes, ... it does not necessarily follow that they feel comfortable with African Americans in practice or want the government to ensure that civil rights laws are obeyed. Although whites may no longer be principled racists, conscious adherence to the abstract principle of racial equality does not automatically translate into acceptance and liking; nor does it imply that negative beliefs about African Americans-prejudicial stereotypes-will simply vanish. On the contrary, the negative feelings and demeaning stereotypes attached to African Americans over the centuries have proved to be remarkably resilient (2007: 68-69).

He continues the argument by describing the persistent prejudice and discrimination that continue to characterize the housing and job markets as well as the judicial system. Citing several studies, he writes that approximately 50 percent of whites hold negative stereotypes of African Americans and blame negative behavior among the latter (deviancy, laziness etcetera) rather than systemic racism for their low social status. At the same time he shows how these stereotypes lead white Americans to make decisions (higher interest rates for mortgages, redlining, etc) that lead to further segregation and therefore to an intensification of stereotyping. All of this is due in large part to the ways 
in which civil rights legislation was passed and enforced. It is also due to the fact that many white Americans believe that racism has been eradicated and therefore resent any government action intended to improve the status of blacks.

These attitudes help explain my participants' various racist encounters-despite not living in a region characterized by large numbers of whites and where Hispanics are politically—and increasingly economically--dominant. Their experiences also demonstrate the ways in which race still draws bright boundaries in the U.S. that determine how people with black ancestry are viewed by other groups in the society. Leighton's encounter at the airport serves as a good example. While not denied access to resources (housing, employment) the traveler's comment 'Next time I'm going to ask a F-ing white person" suggested that she associated Leighton's blackness, as she evidently saw it, with ability. That is, their failure to communicate was not simply a mutual miscommunication. This employee was black, and since blacks are inferior, he must therefore be at fault.

Rigid racial borders, of course, have also historically had implications for immigrants (Jaynes 2004, Lee and Bean 2007, Massey 2007, Sibley 1995). Immigrants, particularly those who easily varied phenotypically from the white majority (e.g., Asians, West Indians) but even those who would later be allowed to become white (Italians, Poles, etc.), challenge racial boundaries because they bring in new groups that have to be categorized Many of these groups are intermediate, liminal, mixed and thus disturb existing categories. Various reasons including concerns for both protecting white privilege and for eliminating competition have prompted action on the part of dominant whites geared toward restricting immigrant access to certain resources. While certain 
European groups especially those from Southern and Eastern Europe have at different times been excluded from incorporation into white America, these groups have largely come to be accommodated into mainstream America and are now considered 'white'. As Lee and Bean (2007) point out, however, similar accommodation has not been made available to immigrants of color, especially those who by virtue of their dark skin color and socio-economic status might be lumped together with the "underclass."

Massey (2007) traces persistent anti-immigration sentiment since the late $19^{\text {th }}$ century - especially highlighting the demonization of Japanese during the $19^{\text {th }}$ and early $20^{\text {th }}$ centuries and, more recently, undocumented immigrants, particularly Mexicans. Massey argues that at one point, Mexican labor was considered preferable to Japanese (the latter's success at business was perceived as a threat to white privilege). He shows however that beginning shortly after the 1929 crash of the American stock market and continuing to present day, Mexicans, especially the undocumented, have increasingly been viewed as expendable laborers and unassimilable as a group. Even those who live and work legally in the U.S. or were born here to Mexican immigrant parents are tainted by the discourse that frames all Latinos as "illegals." Though they cross the Mexico-U.S. border, they are not fully accepted inside the socio-cultural boundaries of the U.S. as a nation. As a result they have experienced increased racialization and demonization along with other Latino groups. A very current case in point is the passage into law of Arizona Senate Bill 1070 in April 2010, which aims to stem the flow of undocumented immigration. Among other things, the law enforces the federal requirement for aliens to bear immigration documents at all times, a mandate that critics argue will foster increased racial profiling - a particularly insidious form of boundary-work. These experiences have 
not occurred by chance. Massey shows that members of various sectors of American society (including "academics, pundits and politicians") have participated in boundarywork geared specifically toward presenting Latin American immigrants as both a threat and as socially undesirable. Examples cited by Massey include Harvard political scientist Samuel Huntington who argued in 2004 that the growing immigrant Hispanic population threatened the cultural and linguistic unity of the nation and conservative pundit Patrick Buchanan who as recently as 2006 compared Mexicans to "barbarians invading ancient Rome," warning that Mexicans would attempt to invade the U.S. and re-acquire the American Southwest (Massey 2007: 146).

Jaynes (2004) argues that contemporary middle-class Americans have constructed notions about "the Other" that are constituted by the invention of the "underclass." The term, originally introduced by social scientists as a clinical term to describe changes occurring in America's racial and class structures in post-World War II America, has resonated with historical long-standing notions among Americans who have always viewed the U.S. as a middle-class society built on the principles of a Weberian version of the Protestant Ethic (which demanded that everyone followed a 'calling.') There is no room in that belief system for "unproductive and parasitic classes" of society. Americans have thus come to view any group whose socioeconomic status and behavior are oppositional with those normally linked with the middle-class as culpable for their low social status and therefore part of the "underclass." While "underclass" has various referents, the term has come to be linked with the nation's poorest urban classes and especially their offspring who typically display socially deviant behavior. And typically poor blacks and more recent immigrants from Latin America and Asia have 
disproportionately comprised this group. Thus although whites have made distinctions between blacks as well as Latino and Asian immigrants who have achieved social mobility and those who belong to the underclass, there still appears to be a clear link between race (people of color) and membership in the latter.

Massey and Jaynes view the boundary-work conducted by whites in America as efforts oriented toward preserving their privileged position, a position long held in polar opposition to denigrated blacks. Thus, it is those in the most privileged positions of any society who have the most to gain (and lose) by erecting and maintaining boundaries that segregate themselves off from peoples who are marginalized — and to make sure that both the privileged and the marginalized help reproduce these borders. That is why "naturalizing" boundaries is so critical; to the degree boundaries are viewed by people in a society characterized by these boundaries as normal and even natural, then there is no need to explain nor change them. Dalmage (2000) demonstrates this point very well in her discussion of the border patrolling that has historically characterized marital relations in the U.S. Focusing on interracially married (black/white) Americans and their progeny, Dalmage shows how, for different reasons, border patrolling has occurred on both sides of the color line. During and after slavery, and especially during the Jim Crow era, while whites sought preservation of racial borders to ensure the separation of whites from slaves/blacks; blacks, intimated by their low status and fearing violence especially lynching participated in boundary-work by developing a basis for their own cultural unity. At the turn of the twenty-first century, borders continued to be patrolled by both whites and blacks. Dalmage writes that whites feel the right and obligation to act out against interracial couples. They do so in various ways including disowning family 
members who cross racial lines. She argues that while some "grant acceptance by making an exception to the "rule"' and others feign color-blindness, neither attitude really challenges the color lines that circumscribe groups. Once again, it is worth underscoring that inbetweenness is problematic to established categories; boundary-work not only must erect and maintain the distinctions, it also must find ways to categorize those who are mixed. Both those who are privileged and those who are marginalized, however, feel disturbed by mixed people and work toward resolving the contradictions; that is, both typically try to keep mixtures from happening in the first place.

Border patrolling by blacks, according to Dalmage, occurs largely due to strong feelings of betrayal of the black community by black transgressors into white terrain, when a black person chooses to cross the color line. Objections often come from family and close friends some of whom make repeated efforts to convince these transgressors to abandon their interracial relationships. In addition to strong feelings of betrayal, black border patrollers believe that interracially married blacks endanger themselves. Dalmage, a white woman who is married to a black man, writes, for example, of a black woman who approached her husband and advised him that being in that relationship could lead to his being killed. But their objections seem to be largely based on concerns about loyalty to the black community. Intermarriage with whites is viewed as complicity with the white oppressor.

Boundary-work thus consists in the efforts all humans engage in to construct and maintain social boundaries that at once include (by creating community) and exclude (by inventing the "other"). It originates in humans' need to organize their world culturally since we are not born with innate behavioral organization (i.e. instincts). Through 
boundary work we erect symbolic boundaries (or conceptual distinctions) among groups but these are not epiphenomenal symbolisms; these are categories with real world consequences because the categories become the basis for social hierarchies. When these conceptual distinctions are widely shared they translate into rigid and carefully patrolled patterns of social exclusion (and inclusion). While boundary-work that is conducted by those members of society who have control over the means of production often leads to social stratification and inequality, the less privileged also participate in boundary-work.

\section{Chapter Conclusion}

Understanding how boundary-work occurs is helpful for explaining the racial experiences, as well as racial categories and identities that my participants encounter in the U.S. These experiences are themselves expressions of boundary-work. Experiences with racial slurs, police harassment, exclusion from employment based on race, etcetera are examples of privileged groups acting to preserve the boundary between whites and non-whites. The South Florida situation is more complicated as participants find that boundaries are being drawn by Hispanics as well, in large part because Hispanics predominate. Regardless of the source, what my Jamaican interviewees express is how boundaries that they do not feel comfortable with are being drawn around them. They are being drawn by whites, by Hispanics, by those who seek to place them into rigid racial categories and who are uncomfortable with their own more fluid self-conceptualizations. Jamaicans perceive or feel the boundary-work more consciously in the U.S. since the boundaries themselves vary from those Jamaicans grew up with in their homeland. Thus, the context of having migrated to a location where race has been socially constructed 
differently yet operates much as race operates elsewhere - as organizing humanityaffords Jamaicans a different perspective on race and themselves.

It is participants' discovery of racial boundaries that in the U.S. are much more rigid and more carefully patrolled than they are in Jamaica that is most startling for them. They are perhaps less concerned about being excluded from any particular racial group than they are about (1) having to 'define' their race in ways that place them in one racial category or another and (2) being forced into the 'black' category and thereby, ipso facto, the underclass. The former concern is no different from that held by members of the U.S. multiracial movement who have clamored for more racially inclusive categories on census and other government forms. The difference is that the latter are battling a binary system in which they were raised, and to which they are accustomed, while my participants, as immigrants, are facing a racial system that is largely unfamiliar and thus discomfiting.

Mixed race Jamaicans I interviewed definitely "see" race in the U.S. As evidenced in their own words in this chapter, their daily lives involve encounters with U.S. constructions of race. The literature on boundary-work makes clear, however, that boundaries — although frequently not erected by those who become marginalized—nonetheless are typically maintained by those who become marginalized. The critical next question to ask, then, is whether or not mixed race Jamaicans whose understanding of racial boundaries is enhanced in the cross-cultural context of life in the U.S. apply this analytic advantage to themselves. Do mixed-race Jamaicans living in the U.S. not only perceive how American racial boundary-work operates on them but how they, 
themselves, do racial boundary work on each other? This is precisely the question that I pose in the next chapter. 


\section{CHAPTER VI}

\section{Navigating Racial Boundaries in the U.S.}

Shortly after his untimely death on June 25, 2009, well-known African American musician and performer, Michael Jackson was honored at the 2009 Black Entertainment Television (BET) Awards Ceremony. The ceremony's host, musician and actor Jamie Foxx (also African American), opened by stating, "Michael Jackson, a black man, is being celebrated. He was a black man. He belongs to "us!" The latter statement was made emphatically and repeatedly, while Foxx strutted from one side to the other of the stage. This was an interesting claim given that Jackson's popularity and wide appeal crossed racial, ethnic, and national lines. The claim was striking to me also because Jackson had been hailed as the musician who through his talent and music had broken down barriers for black artists, broadly speaking, by producing works that attracted the attention and adoration of a wide variety of fans representing various cultures and even generations. Moreover, Jackson's personal life, especially his marriage to two white women suggested a comparatively cosmopolitan attitude (that is, compared to that demonstrated by Foxx's statement at this event). So, while Jackson had been recognized as an African American and therefore as racially "black," his life suggested that he possessed a cosmopolitan attitude that stood in contrast to Foxx's claims. Foxx's act of claiming Jackson as "belonging to us" seemed to dismiss his cosmopolitanism as well the broad appeal of his work. It was also an act of boundary-work.

The previous chapters have explored boundary-drawing and boundarymaintenance in Jamaica and the U.S. In both societies the boundary-work explored has been primarily carried out by powerful sectors (whites, browns) so that the discussion has 
centered on the use of boundary-work to create and maintain social hierarchies where the creators and maintainers are the ones who benefit from this work. Boundary work, then, is not just about creating classifications but about sorting humans into separate groups. That is, in the chapters to this point I have emphasized the use of boundary-work by various groups to both reinforce their relative power and to ensure that their higher social status is maintained. I have documented, moreover, the efforts of those dispossessed by these boundaries to challenge, transgress, and dismantle barriers to their social mobility. In the last chapter, I explored study participants' experiences with boundary-work in the U.S. emphasizing stories that described the various ways in which they felt that racial boundaries, not of their choosing, had been drawn around them.

Using survey and interview data, this chapter explores participants' responses to their encounters with boundary-work in the U.S. and their efforts to navigate racial boundaries. It analyzes respondents' various racial identification choices in the postmigration context and identifies the factors affecting such choices. The chapter addresses the following questions: How have these mixed race Jamaicans responded to the boundary-work they encounter in the U.S.? How do they navigate U.S. racial boundaries? Do they navigate these boundaries in ways that reflect race as they remember it from Jamaica and, if they do, does this suggest that they might work toward a post-racial society in the U.S.?

In an interview in May $2009^{20}$ with academy award winner Sidney Poitier, the actor who migrated to the U.S. from the Bahamas, he shared his encounters with extreme racism in Florida in the 1940s. He recalled never having felt so "described" before

\footnotetext{
${ }^{20}$ The interview aired on NPR's morning edition on May 20, 2009.
} 
moving to Florida. Like my study participants, Poitier had left a West Indian country (in his case, the Bahamas) with a racial worldview that had been formed there, and encountered a racial system in U.S. that was entirely different. The change in context exposed him to a different social construction of race, and to racist encounters that were particularly difficult to face. As Poitier recalled it, "I couldn't adjust to the racism in Florida. It was so blatant that I decided that it was not a good mix. I had never, in my early life, been so described [italics mine] as Florida described me. I think...Eventually I think that Florida said to me: "You are not who you think you are. We will determine what you are. And I decided 'no' I will determine who I am. And I wound up in New York!" Poitier's response to the feeling of being "described" was to flee Florida for New York. But my participants all continue to reside in Florida. Moreover, as the previous chapter documented, for some the feeling of being "described" was as a result of racialization in U.S. locations other than South Florida. This chapter explores their response to those descriptions.

"I am Jamaican" - Ethnic (Post-Racial) Identification

As indicated by my survey ${ }^{21}$ data, an overwhelming tendency among my participants was to elect ethnic (Jamaican or West Indian) identification. That is, when given the choice, survey respondents indicated that they preferred ethnic (Jamaican) identification over any racial label. In response to the nine survey questions that addressed racial identification choices in specific contexts (see Appendix 3), the vast

\footnotetext{
${ }^{21}$ Surveys with questions about racial identifications in Jamaica and the U.S. were distributed via Survey Monkey to all interviewees before their interviews. Of the 34 interviewees, 33, 16 males and 17 females, completed the surveys.
} 
majority - over 75 percent - selected "Jamaican" rather than a specific racial label. As was mentioned in chapter two, this finding resonates with those of various studies about West Indians in the U.S. (see for example, Brettell 2007, Waters 1999, Hintzen 2004). West Indians with black ancestry learn about the stigma attached to black racial identification in the U.S. and elect an ethnic identity ("Jamaican" "Trinidadian" "West Indian") in their attempt to avoid that stigma. Writing about Jamaicans, Brettell (2007: 67) argues that they "not only attempt to distance themselves from the unflattering assumptions that are made about blacks, they also ally themselves with Grenadians and Barbadians whom they would see as different if they were in Jamaica. Similar observations were made earlier by Nancy Foner (1987) who described "Jamaicanness" or "West Indianness" as a way for islanders to draw boundaries to separate themselves off from low status African Americans as well as to express ethnic pride, and, she adds, to claim superiority.

The preference for ethnic rather than racial identification was echoed by a small number of my interviewees as well. Among those participants was thirty-four year-old Cecile who told me she had viewed herself as "brown" in Jamaica, although she had been frequently called "white girl" by her peers. In explaining her racial ancestry, she described her mother as "black," her father as "mixed," and her maternal grandparents as "white" (grandmother) and mixed (grandfather). Her paternal grandparents were described as "white" (grandmother) and "black" (grandfather). Cecile had lived in the U.S. for 19 years. I asked if she remembered what racial category she used to select on government forms during her early years in the U.S. She replied, "Black, and I hated it." We both laughed. "Why did you put black?” I asked. She replied, "Because I had no 
other choice. And if the 'other' [category] existed, I am sure I chose 'other,' because I don't see myself as African-American." She continued, “Ok. This was the order. If there was 'other' I'd do 'other'. If there was 'black,' then I'd do 'black.' But that was my second choice. But if there's 'African American,' I will not select it!’ Cecile indicated that she views herself as primarily Jamaican and thus prefers to apply an ethnic, rather than racial, label to herself, "I identify myself as not black, not white, not mixed. I just see myself as a Caribbean person, as a West Indian person.” As such she struggles to navigate racial categories and resolves the conflict by attempting to avoid racial labels altogether.

The use of ethnic rather than racial labels by individuals might be viewed as reflecting post-racial attitudes and therefore unbounded ones, rather like that of the national identity participants claimed that they held dear in their home country, Jamaica. Yet this choice, while seeming to be boundary-free as far as race, is really also a type of boundary-work in that it involves the drawing of lines of demarcation that determine ingroups and out-groups. Moreover, holding an ethnic identification does not necessarily entirely preclude the use of racial labels. That is, the fact that based on survey results, participants indicated a preference for ethnic identification does not necessarily mean that individuals have adopted a post-racial stance. Indeed, identifications are often complex, and multidimensional. Unlike face-to-face interviews, surveys leave little room for exploring the multiple dimensions of identities or the factors that explain them. The next section thus examines interview responses to questions about participants' current identifications. 


\section{Racial Self-Identifications "Choices"}

"I am not black": Mixed, Multiracial, Other

In contrast to survey responses that showed over $75 \%$ of the sample selecting ethnic rather than racial identifications, only a few interview and focus group responses showed a similar tendency. In fact, the overwhelming majority of interviewees $(82.3$ percent), indicated that they currently hold racial identifications. Of that number, more than half (56 percent) of the sample reported adapting non-black racial identifications in the U.S. context. And of this group 12 (or 35.3 percent) indicated mixed-racial or multiracial identification. Among those who indicated the "choice" of a racial label as "mixed" was 37-year-old Patrick who when asked how he characterized himself told me, "I see myself as mixed; always mixed." Patrick, who at the time of his interview had lived in the U.S. for 18 years, explained that despite his current self-characterization as "mixed," during his early years in the U.S. he used to check "black" on forms that collected racial information. The reason, he explained was while laughing, was that "they didn't have 'mixed' at that time." Patrick went on to tell me, "I know that some people see me as being black. In fact I think a large number of people in this country do. This is the feeling I get all the time. A small number recognize that I am mixed. But I tend to be labeled much more quickly as being black." Thus, while Patrick has evidently had racial encounters in the U.S. in which he had been characterized as "black" he now holds unwaveringly to his self-characterization as "mixed" regardless of others' opinions or the constraints imposed on him by existing racial categories on forms. Additionally, while after immigrating to the U.S. he initially checked "black" on U.S. forms, he says, he did so only because there was no blended or mixed category available in those days. I asked 
which option he now chooses on forms and he replied, "I always try to look for mixed or bi-racial." And where he cannot find one of those options, he checks "other" and writes "multiracial" in the section that permits clarification.

Thirty-two year-old Vivica shared very similar perspectives, that is, she was equally adamant in her resistance to being identified as black. Vivica who had lived in the U.S. for 15 years, told me that she had identified as Indian in Jamaica. She described her mother as Indian and her father as mixed (Spanish [white], Indian and black). Vivica attributed her self-identification as Indian to the fact that she had been characterized by others this way in Jamaica. But upon arriving in the U.S. she recalls selecting "black" on forms during her early years here. "Why did you select black?" I asked. "Well," she responded, “because when I went for my driver's license at age 18, that's what the lady put. When I went for other documents that's what they would put. They would have their impression of me and just mark it." Vivica explained that she no longer makes this selection on forms. She explained how it occurred to her to change her racial identity: "But then I started to think, 'I am not black. I'm not 100 percent black. Why does everybody keep putting black?' And so the first form I came upon that actually had an option for two or more races, I thought, 'Well I'm definitely two or more races.' So I started putting that on forms.” These two cases show mixed-race Jamaicans going through a process in which immediately after immigrating they accepted the racial classification assigned to them then and then later rejected it. The question is: what explains that change for these individuals? I discuss factors below that explain identification choices but the data does not explain their initial apparent acquiescence to their racialization beyond perhaps the likelihood that participants did not believe then that 
they had a choice. The latter comment certainly suggests that when an alternative became available, participants took advantage of it.

Forty-four year-old Glenn was particularly emphatic as he explained his selfidentification as multiracial. Glenn, who described both parents as "multiracial" had lived in the U.S. for 29 years. He explained his self-identification in this way:

I put "multiracial" on forms, because I feel that this is the appropriate option. America is changing. I never used to do so (I used to put "black") because the choice was not there. But it does exist now. So I guess in a sense my racial identity is changing. Well not so much changing. I'm also trying to force America to recognize the fact that there a lot of different people out there [like me]. I want America to recognize that there's no pure race: there are no pure white people; there are no pure black people. I guess someone could argue with me but these facts are supported by research that has been published in Time magazine. All sorts of researchers write about these things. Archaeologists too. So what I'm saying is that America should be forced now to allow the multiracial option. The fact that some are not willing to do so sheds light on the attitudes of those who create those forms.

Glenn had evidently not only given considerable thought to the idea of race but, perhaps unlike most participants, had also read extensively about the subject. During his interview he seemed anxious to convince me that race, as it is understood, does not really exist. When I asked, as I had done with other interviewees, what the term "race" meant to him, Glenn replied, "I think we assign people to a certain race as a way of separating people 
and holding certain people down. There's really no race. If you consult classical books archaeologists have found that everything started in Africa. We have proof of that. I can send you an e-mail with the article I read on that. We really started with one set of people." Yet despite this and other similar assertions, Glenn does not avoid racial labels. Rather, he identifies as "multiracial" and, in so doing, he acts in contradiction to his assertions.

Twenty-six year-old biracial (black/white) Peter struck me as a particularly interesting case. The son of a black Rastafarian man and a white Jamaican woman, he also happened to be Rastafarian. When asked how he had identified racially in Jamaica, Peter told me that he did not recall thinking about race:

When I was in school in Jamaica, the idea of my race never came to mind, nor was it ever an issue when my mother came to pick me up from school. However, when I first began school in the States, I remember my mother coming to class one morning and the children, most of whom were black, looked at her in awe. I specifically recall that a few of them turned to me and asked, "Peter that's your mom?" The tone of their question made me feel so uncomfortable that I asked my mother never to come to school again because she was white. I began feel awkward in public places after that.

Peter went on to explain that in the wake of these early encounters he began to identify as "black." "I attribute this forced blackness by those school mates to my identification with the hyper-black consciousness of Rastafari." Yet by the time of the 
interview his self-identification had changed to "mixed." I was intrigued. "So if I'm hearing you correctly," I asked him, "you went from not really thinking about race in Jamaica, to thinking of yourself as black here in the U.S., and then to beginning to acknowledge being racially mixed. Is that so?" He replied, “That's right. As I have grown older, I visited Jamaica over the past few years more frequently. And I have begun to realize that I'm not black, I'm not white...I'm racially mixed you know. So for instance when I was applying for my undergrad degree, I put 'black.' But I'm currently applying for the Ph.D. and I'm putting 'racially mixed."”

Given Peter's Rastafarian orientation I had expected him to hold firmly to black racial identification. Additionally, Peter, who although light in complexion, in my estimation bore phenotype that revealed his back ancestry. Peter, though born in the U.S., had been taken to Jamaica when he was still an infant and raised there until he was approximately eight years old. His early return to the U.S. during his formative years and his evident exposure to an overwhelming black community in his high school seemed to inflect his black racial identification. Indeed, previous scholarship has shown that the social networks to which both pre-adult and adult individuals are exposed and the interaction that occurs in those networks are likely to influence racial identity formation (Rockquemore 1999, Rockquemore and Brunsma 2008). Peter's transition from having no racial identification in Jamaica to a black racial identification during his early years in the U.S. met my expectation that as a Rastafarian he would identify as black. His more recent transition to mixed racial identification, however, was intriguing. That is, I wondered what factors might explain this change. Further analysis provided an explanation that is reviewed later in the chapter. 


\section{The "Other" Race Category}

Among participants electing non-black racial identifications are those who told me that they select the "other" option on government and other types of forms. The "other" category has been found to be particularly popular among English speaking West Indians, who after selecting the category rather than choosing a race, then enter their country of origin (Waters 1999). And that popularity was reflected among study participants over 40 percent of whom indicated that at one point or another they had selected that option. Multiracial (black, Indian, white) Karlene laughed as she told me, "It depends on how I'm feeling. Sometimes I put African American/black. And sometimes I put 'other."' "When you select 'other"” I asked, "Do you do so with or without clarification?" She replied, "I put 'other' and beside it I put 'mixed."' I asked her to explain her choices and she replied, "It's probably just because even though I really try not to identify with racial barriers or anything like that I guess that's how I was raised you know--as a black Jamaican.” I further probed, "So when you do put 'mixed' why do you make that choice?” She responded, “Because I don't like to be called 'African American.' I am not American. I'm Jamaican. Or sometimes I'll put 'Jamaican' just to be mischievous. You know it irks me that they need to know all of this information. Why do they need to know that?"

Karlene did not avoid being identified as "black" as she had identified as black in Jamaica. Her objection was to the collection of racial data. Decisions to check the "other" category were made by her, moreover, when "African American" was the only available category on a form for people of African descent. Since she did not view herself as "American" she was not satisfied with that category. Biracial (black/Indian) Anita 
expressed similar views. At the time of her interview Anita was 34 years old and had lived in the U.S. for 15 years. While she claims not to have thought much about race in Jamaica, she recalls being perceived as "Indian" there. When I asked her if she currently thinks about race, she said:

Yes. I think about race rather frequently, especially when we have to fill out applications. They always have black and Hispanic and white, and others. And I only look at myself and my husband and my father, even my son. We have conversations about who we are, that is, whether we are black or Indian, because I'm half-Indian and my husband is fully Indian. My son, I guess, would be considered three-quarters Indian. My son and I talk about race frequently when we go to fill a job application. I don't consider myself like straight black. So I usually show my son the section that says "other." I think that's the part that fits us.

Anita's response to my question suggests that, in the U.S. context as opposed to in Jamaica, she has become preoccupied with the question of her racial identity. While she clearly understands that she is viewed as black in the U.S., she is uncomfortable with that designation. Thus in a clear act of boundary-work, she instructs her son to select "other" as the category that is most appropriate for their family.

The "other" option, then, was presented as the preferred "category" for Jamaican immigrants like Anita when the existing racial categories did not reflect that individual's racial self-characterization. Its popularity among my participants arises from the fact that it permits people to avoid choosing a true racial category and, for those inclined to do so, the option of writing in the "category" they feel really describes themselves-Jamaican 
or "mixed" for example. That is, the 'other' category permits insertion of a racial or ethnic label that fits better than the standard categories for race on forms in the U.S. Asian (Indian/Chinese) Identifications

The typical race categories found on forms in the U.S. are particularly confusing and disturbing for participants who have Asian (Indian or Chinese) ancestry since they feel that the "Asian" category refers to people who were born in Asia and their descendants. Their West Indian ancestry makes it difficult for them to neatly fit themselves into that category. Only one participant, 25-year-Susan, indicated identification as Chinese in the U.S. "I guess I think of myself as more Chinese than anything else," she told me. But the thing is that I also do have black blood in me and maybe a little bit of white. But what does that mean to me? For me it's just about my heritage. It's where I'm coming from." Susan explained that although she is aware of being racially mixed, she does not really view herself as "mixed." "I say that though because so many people look at me and say 'Oh but you're not mixed. You're Chinese!' And I just cannot be bothered to argue about it. I don't feel like dealing with history. So I just say 'Yeah I'm Chinese.' It's just easier, I guess.”

While five other individuals indicated initially identification as Chinese, Indian, or Asian during their early periods in the U.S. they had either since changed their racial self-identifications, or reported viewing these identifications as one among others. That is, these participants did not report Chinese, Indian, or Asian as exclusive identifications. Rather they reported using multiple racial identifications, one of which might be Chinese or Indian in certain contexts, and using other labels (such as "black" or "Jamaican") in 
others. Sometimes these participants also resorted to the "other" racial category when completing forms.

\section{$\underline{\text { Contextual Identifications }}$}

My racial identity has fluctuated over the years I think as a result of the environment I'm in. I have moved around, as you know, so I feel like my surroundings affect how I relate to people and how I'm perceived.

Currently, I identify with being mixed but being predominantly Chinese since I have more knowledge of my mother's ancestry than my father's. On a form I typically check "other" and write "mixed." If I don't have an opportunity to check "other" I usually mark "black" and "Asian."

As I had done with other interviewees, I studied Tracy's features as she spoke. She appeared to me to have a "Chinese" phenotype (light skin, long dark-brown hair, slightly slanted eyes). I asked her to describe her parents racially and she said, "My mother is mixed with Thai, German, and Chinese. Her father was literally a run-away from China. My father is predominately black, Indian, and Scottish.” Tracy told me that during her childhood in Jamaica she had primarily identified as "black" since most of her friends were black. But this changed during the latter three years in high school when she made friends with schoolmates who were racially mixed. Her above-cited statement indicating changing identifications refers primarily to the U.S. and the different contexts in which Tracy has found herself in this country. After migrating Tracy lived in New Hampshire for 18 months. During that time she joined the International Students' Organization in her university. "There were two guys: one from Trinidad, one from Tobago. There was another guy from Puerto Rico. We had a quite a few members from 
China and other countries. So it was interesting because there were periods during which I identified with the Asian culture because of the Chinese students who were members. There were other times I thought I was just black. And then there were times in which I just couldn't quite figure out quite where I fit in.” Tracy's exposure in that student organization to various racial and ethnic groups facilitated the shifting of her identification from group to group depending on the group she was with. Her identifications "fluctuated" during that period as she struggled to find her "place."

Tracy's shifting identifications reflect those of just over one-quarter ${ }^{22}$ of my participants for whom context is important to their racial identifications. Multiracial (black/white/Indian) Nicole for example, told me that she primarily identifies as "mixed," she does not always select that category when completing forms. She explains, "I think that sometimes it just depends on how I am feeling that day. Sometimes I will put "mixed," sometimes I will just put "black" because I don’t feel like explaining."

Biracial (black/Indian) Karen shared similar sentiments when I asked her if she had had any experiences in the U.S. that had changed her perception of herself. "Well here's my dilemma," She responded. "When you're applying to universities you're told that if you check black then you tend to get scholarships. So it's beneficial for you to do so. And my friends have always joked about the fact that I can get away with it because I can put that I'm black and I can put that I am a woman! So I can get away with achieving that. But I have abused it because I have used it only when it's convenient. In reality if I'm just generally asked to indicate my race, I would put 'mixed' or 'other.'” As she

${ }^{22}$ Given that identifications are situational (Cornell and Hartmann 1998, Hintzen 1999, 2004), it is possible that identifications changed based on context, even among participants who reported the use of only one racial (or ethnic) during interviews. Opportunities to observe participants outside of the context of the interview might have revealed other dimensions to their identifications. 
finished, I probed saying, "It sounds like you're saying it's kind of contextual; it depends on the situation?" "Yeah!" she replied. "So," I probed further, "does that mean that your perception of yourself has not changed? You identified as 'mixed' in Jamaica, identified as 'mixed' when you arrived, and you still identify as 'mixed' except for where you think it may be useful to do otherwise?" "Well," she continued, "it depends because if Obama wins the election I'll be like, 'Yes! I'm proud because I'm black!'”

Karen's comments illustrate that not only is racial identification flexible and contextual, it can also be instrumental. It is true that she may select the "black" category school or scholarship application forms in order to take advantage of scholarships and other benefits reserved for racial minorities. It is also true that that she primarily selfidentifies as "mixed." Yet her strong identification with blacks, especially in the wake of the 2008 U.S. presidential election in which Barack Obama was a candidate, suggests that suggests that while Karen possesses and utilizes multiple identifications she still has a dominant identification--black. The question is whether participants, who like Karen, possess more than one racial identification, hold one of them as the true identification while using others where convenient (such as to take advantage of minority benefits) or when they are forced to do so (such as when an official insists they make a racial choice on a form) or whether they, in fact, view themselves as holding both or all these identifications.

It is well-known that people's identities are neither fixed nor static. Individuals often develop multiple identifications. As Reuel Rogers (1999:166) put it, "Racial and ethnic identities are complex, fluid categories. Individuals may have multiple identities that they hold simultaneously and manage differently within the varying contexts of their 
social and political lives." Scholars of the multiracial experience have noted that many multiracial individuals possess multiple identifications and that their identifications are often situational in nature. One type of identification may be evoked in specific contexts while another may be called up under other circumstances (Cornell and Hartmann 1998, Daniel 1996, Hintzen 1999, Rockquemore 1999, Rockquemore and Brunsma 2008). While scholars (Rogers 1999, Waters 1999) have shown that as Caribbean immigrants hail from multiracial and multiethnic societies they do not deem it necessary to choose between racial and ethnic identifications, Hintzen $(1999,2004)$ has argued that West Indians in the San Francisco Bay area perform different identifications in different contexts, often seeking to manipulate their multiple identifications for instrumental purposes. While they evoke an ethnic West Indian identification, and in particular, make use of the myth of their status as a "model minority" often to avoid association with low status African Americans, these immigrants evoke "black" identification in order to take advantage of educational and other opportunities reserved for African Americans. They perform different identifications with an intentionality that is akin to Karen's when she indicated that she identifies as "black" whenever there may be some financial benefit for having done so.

What I found, then, was that mixed race interviewees preferred forms that permitted them to elect more than one racial category. They took advantage of this new option whenever possible. If this option does not exist they tend to select 'other' race unless that is not an option. Some participants elect the "other" category even if the multiple race format is possible because they can then write in what they truly wish to answer such as "Jamaican." Members of the latter group are largely dissatisfied with 
existing racial categories and/or have not encountered forms that permit more blended identifications. And still others demonstrate multiple and multi-layered identifications as might be expected from a group of racially mixed individuals. What I interpret these "everyday forms of resistance" (Scott 1985:xvi) to racialization to signify is that mixed race Jamaicans push back the one-drop rule boundary that, nonetheless, presses constantly against them in daily life. Others classify them as 'black' but they push back that classification for one or more of the reasons mentioned above. These efforts confirm my expectation that given changing racial dynamics in the contemporary U.S., various possibilities for racial identification might exist for my participants. That is, as I surmised at the beginning of my research, given post-1965 demographic changes in the U.S., participants would encounter more than just a racial dichotomy and as such, would demonstrate various identifications after migration. It is important to note, however, that not all participants are holding non-black identifications. Just under one-third (11) of my participants indicated that they currently identify exclusively as black. Of this number, 6 indicated they had also identified in this manner in Jamaica. In sum, of my 34 respondents, only 5 (or 2.5 percent) had experienced an identification shift from nonblack identification in Jamaica, to exclusive black identification in the U.S. Their number, however small, is suggestive that some people acquiesce to the one-drop rule. The next section, thus, explores the testimonies of this group.

\section{$\underline{\text { Racial Identification Shift: "I See Myself as Black" }}$}

Thirty-five year-old biracial (black/white) Audrey explained early in her interview that in Jamaica she had lived an experience of some privilege owing to her mixed racial ancestry and "brown" identification. Insisting that her family never talked 
about race, as other participants had done, she emphasized that concerns related to class had taken precedence over race in family discussions. Nevertheless, she felt that her light complexion had earned her preferential treatment especially in the schools. When I asked about her racial identification in Jamaica, she told me she viewed herself then as "brown." And when I asked about her racial identification in the U.S. she said, "I don't have the same kind of privileges here in the U.S. I'm only seen as black and that's it." I pressed, "So you're telling me how you think you're seen. I'm interested in how you now see yourself? When you arrived here you said that you would have identified yourself as "brown." "Yes," she said, "Or checked 'other.' Now I check 'black."” I sought further clarification, "Well you know, one might check 'black' on a form..." She interrupted, "I see myself as black."

Audrey is among the very small number of participants who reported that their racial identification had shifted from something other than "black" in Jamaica to exclusive identification as "black" in the U.S. Most of these individuals felt that the change was hardly their choice. That is, identification as "black" was forced on them by external or structural forces. Multiracial (black/white/ Indian) Jennifer expressed similar feelings of being forced into identification as black while responding to my question about how she completed the race category on forms:

I had to get used to calling myself black (fully) because that's the only thing I could do. The only options were white, black, Asian, Pacific Islander, other, or Hispanic. So for me, here, my race was black. Because the only type of Indian they had on forms was "Native American Indian" and I'm not a Native American Indian. I guess because I was dealing with 
a different country, I just wrote black. It was easier to just write black, because I knew it would be difficult to explain that I am also Indian. If somebody asks me about my looks, then I'll say I have a mixture of Indian. But I am not likely to start that discussion because I know race was very much a big thing here. I mean that's the way I'm seen here anyway. People here just tend to think of me as black.

Jennifer's current self-identification as "black" evolved in the U.S. context. In Jamaica she had become accustomed to identifying with her Indian ancestry. As she put it, "I never considered myself as black in Jamaica. In Jamaica I was considered Indian or coolie." Upon her arrival to the U.S. she had searched for a racial category that matched her self-conceptualization. In her view, it was the absence of such a category, as well as the knowledge that in this country she is generally viewed as black, that pushed her toward identifying as black.

Another case of changing to "black" was multiracial (black/Chinese/white) Sean, whose story of being told at the airport that he was "black" not "Chinese" was shared in the last chapter. Biracial (black/Indian) Albert who also shared with me several encounters in the U.S. in which he had been racialized as black. As a result of these experiences Albert's self-identification gradually changed. Among the first of these encounters was one that occurred while he was an undergraduate student. He recalled that "When I first went to [a university in Boston] in 1998, they used to hold lots of workshops about race, culture shock, and cultural identity. I remember sitting around the table with a lot of people. Some of them were friends then and are still friends now. Some students from Africa used to attend those meetings. And once, a certain girl from Egypt 
came. She was brown and she had curly hair. She and I began to argue when we had to talk about race. I had informed everyone [before] that I didn't think I was black. I told them I thought I was Indian. She got very upset and she asked, 'What else could you be? You don't know who you are!' This was somebody who at that time I thought would have been able to relate to me. I would never have thought that she would consider herself black, just because of what she looked like, and because there are people from that part of Africa, Egyptians, who as far as I have noticed, don't at all look like what I would have called 'black' at that time."

For Albert this encounter had clearly been disconcerting. He had viewed this young woman's "brown" phenotype through the more multicolored lenses of Jamaica. In his mind, she was similar to himself, that is, belonging to an intermediate group, as he had in Jamaica. Her confrontation and accusation were thus completely unexpected. This was just one of several instances in which Albert's former identification as "Indian” was contradicted in the U.S. I asked Albert how he identified racially at the time of the incident and he responded, "Other; just other." But Albert continued to have experiences with racialization, "One time, here in Miami, not in Boston, I was at the mall with some friends. I was sitting a little apart from them. I was waiting to watch a movie. The movie hadn't started yet, so they haven't allowed us inside. So we were just sitting down waiting. And these white boys kept passing by. One of them came over to us and said, 'Why you're looking at us like that?' And we said, 'We weren't looking at you. You're passing in front of us. We see you; but we're not looking at you.' They started giving us an attitude and we walked off. But about ten minutes later we noticed that the place was filled with white people. But not your typical white people: these were rednecks. And 
before we knew it, we were surrounded. They were pointing in our faces and asking 'Why are you looking at these girls like that? You know you shouldn't be looking.' They were calling us 'Nigger' and stuff like that. And, I was like, 'Listen, I'm not even from here and I don't understand what's going on. We just want to watch a movie.' And I was trembling. And then it got physical. We were in a fight and the police had to come and separate us." "What happened when the police came?" I asked. "Nothing. Nothing ever came out of it no matter how much we complained." When asked how these encounters had affected him, Albert indicated they had impacted his racial selfconceptualization, that the boundary-work had caused him to rethink his race. "I now consider myself black." He told me. "And I tell you something else: when I go to Jamaica now, I no longer consider myself to be Indian. I tell people there that I'm black."

Not every individual who reported a change to racial identification as black felt forced into that transformation by racial encounters and boundary work. Some participants spoke of their current black identification as their own choice. One such person was 48-year-old multiracial (black/white/Indian) Christine, who in my estimation appeared clearly to be multiracial, owing to her light complexion, European facial features and brown wavy hair. Despite being aware of her membership in the "brown" class, Christine claimed to have held no racial identification in Jamaica. Christine explains her black racial identification in the U.S.:

In Jamaica I didn't have a racial identity, even though when I visit, I can see that there are still the lingering forms of privilege there which seem to decrease every day [laughs]. Here, however, I identify myself as AfroAmerican. Jamaica is a part of North America, geographically, and I am 
of African descent. I think it's important to identify with the Diaspora.

We have a huge African Diaspora outside of Africa that forms a voting bloc, and this is the bloc that I'm driven to identify with: African Americans and Afro-Caribbeans and other parts of the Diaspora. We are a huge voice.

Christine's strong political identification with African Americans, and therefore as "black" is likely the result of racial encounters, such as the one shared in chapter five, in which she was denied employment on racial grounds. And her activism over racial concerns is likely attributable to those encounters. Early in her interview, Christine shared that she frequently thought about race due to her work with a civil rights organization whose mission, she says, "is to level the playing field for minorities, women, elderly, handicapped, immigrants, so that they can have equal opportunities." In explaining her black identification, however, Christine does not mention her negative racial experiences. Instead she emphasizes her strong sense of connectedness to people of African descent globally. It seems that in Christine's estimation, the decision to identify as black is one that she made of her own volition based on her commitment to civil rights activism.

Interviewees' responses contradict indications from survey data from that most (over 70 percent) participants prefer ethnic (Jamaican) identification over any racial label. Most participants, in fact, hold specific racial identifications as multiracial or mixed, Chinese or Indian, or black. My findings therefore support assertions that changing demographics in the U.S. are increasingly rendering existing racial categories obsolete (Lee and Bean 2007, Rockquemore and Brunsma 2008, Waters 1999). Furthermore, my 
interviewees' selection of primarily non-black identifications provides additional evidence that there is a growing number of people who are challenging the one-drop rule. Yet, as my research has shown, despite these challenges, the one-drop rule continues to be the primary force that determines racial identification in the U.S. It is therefore significant that most are not electing a black identity. And their failure to acquiesce to the one-drop rule raises questions about what factors explain this outcome. The experiences of Garry and Christine shared in this section, point to racism as one of the main factors affecting racial identifications. Analysis of my data revealed additional factors that have affected interviewees' identifications in the U.S.: phenotype, characterization by others, and socio-cultural interaction. These factors are discussed in the next section.

\section{Factors Affecting Jamaicans' Immigrants Racial Identifications}

\section{Phenotype and Characterization by Others}

Previously in this chapter I shared biracial (black/Indian) Anita's preoccupation with racial identification, and in particular, her concerns about holding an identity that did not restrict her to "blackness." As I reviewed Anita's stories, it became apparent that her racial characterization as "Indian" while in Jamaica had strongly influenced her perception of herself. I asked her how she would have characterized herself racially had I interviewed her while she was in Jamaica and she replied, "I would have told you that I'm black, but I'm also Indian.” "Ok," I said, "and did you characterize yourself as black but also Indian based on your skin color, hair, lips or some other feature or reason?" She replied, "It was due to the fact that my dad is Indian. It had nothing to do with hair or skin color or anything else.” That is, she denied that her phenotypical features had influenced 
her racial self-identification. As the interview progressed, however, it became clear that her characterization by others as "also Indian" in Jamaica due to her physical appearance was another possible source/cause, "In Jamaica when somebody looked at me the first thing they thought... They didn't think of me as a black person; they thought I was Indian. They don't look at me as what I will call a Negro. Sometimes they would look at me and ask, 'What are you? Are you Indian?' because Jamaica is mostly Indian and black." ${ }^{, 23}$ Anita's recollection of her Indian ancestry being recognized in the Jamaican context has dramatically impacted her racial self-conceptualization. As discussed at length in chapter four, participants whose phenotype made them stand out in Jamaica (that is, those with fair complexion, long and straight, or curly hair) have strong memories of being racialized in varying degrees in the home country. Like these participants, Anita recalls being asked "What are you?" questions and believes she was characterized as Indian because of the large number of Indians in her community. "What are you?" questions continued to be asked of Anita in the U.S., "Often when we go out people look at us and ask, 'What are you?' They tend to think of me as being black but they seem to also realize that I'm mixed with something else. So they will always ask me, 'What are you?' or 'What are you mixed with?' and I always say, 'I'm Indian.'” Anita's experiences in the U.S. served, it seemed, to affirm her self-characterization as not "just black." That is, she continued to be characterized by others as not just black, "They never look at me as a straight black person. Even at work, people never seem to think I am light-Jamaican or black or whatever. They will always look at me as Spanish [Hispanic]

\footnotetext{
${ }^{23}$ Anita's latter comment is, of course, not quite true. According to Jamaica's last census count in 2001, Indians comprise only .89 percent of the total population. Anita's perspective appears to result from exposure through her family and community in a rural parish of western Jamaica.
} 
or Indian or whatever." Thus, while she recalls that in the U.S. she initially checked "black" on forms that collected information about race, she began to question the appropriateness of that category for both herself and her son. "My son and I talk about race frequently when we go to fill out a job application. I don't consider myself, like, straight black. So I usually show my son the section that says 'other.' I think that's the part that fits us.” For Anita not identifying as black has evidently become so important that, as noted above, she has given her son instructions for the future, "Ian, if you're going to complete an application, don't put 'black'," she tells him.

As Anita continued to speak it became clear that her refusal to accept the onedrop rule was related to the rule's application without regard for physical appearance. For Anita, phenotype clearly takes precedence over all else in determining racial identification, "The other day I spoke to my 14-year-old niece Sanya who is mixed with Indian, black, and white (but when you look at her, she doesn't at all look black). But she said to me, "Aunty, I am black!" "Was she born and raised here in the U.S.?" I asked. "Yes, she was born here; raised here. Her mom is white, but her dad is Indian and black. She said, 'Aunty, I told the kids at school, I'm not white!' But if you could see Sanya, you would consider her white. Based on Sanya's skin tone I think of her as white. Yet she told me, 'Aunty, but you know what? I know who I am. I'm black. And nobody can tell me anything different. I told the kids at school." Anita was evidently shocked that her niece, whose skin marked her as white to Anita, and who had also been characterized as white by others, had chosen to self-identify as black. Sanya's perspective stands in contrast to that of her aunt, who, likely based on her own experience primarily in 
Jamaica, but also in the U.S., holds phenotype to be that which should determine one's racial identity.

The impact of phenotype on racial self-characterization is also demonstrated by the stories of 24-four-year-old multiracial (black/Chinese/Indian) Denise. Indicating that while in Jamaica, non-black color terms such as "browning" "Indian" "Coolie" "Miss Chin" had been used in reference to her, Denise told me that her primary identification then had been as "Indian." The reason, she explained is, "Nobody ever really called me 'black." She shared, moreover, that in the U.S. she had often been assumed to be Hispanic (from the Dominican Republic) based on physical appearance. When asked about her racial self-characterization after five years in the U.S., Denise indicated that it had not changed. I asked specifically which category she checked on forms and she replied, 'I would fill out 'other' or 'Asian/Pacific Islander.' I don't really do that anymore because I am really not from Asia or the Pacific Islands. I didn't come straight from India."

Denise's experience demonstrates that phenotypes influence the ways in which one is characterized racially by others. Denise who, in my estimation, lacked the facial features typically assigned to people with either black or Chinese ancestry, continued to have her non-black identification affirmed in the U.S. by the racial characterization by others as "Hispanic." While not confirming the connection she had with her Indian ancestry, such characterization meant that the one-drop rule was not automatically applied to her. Denise indicated that when deemed useful (such as on college applications) she selected the "black" category on forms. But she made it clear that her instrumental use of that category did not reflect her self-characterization. Nowhere is this 
made clearer than her consternation at being referred to as "black" by her Hispanic boyfriend (see, chapter five) and his family - apparently her only encounter with black characterization.

One's phenotype thus affects how one is characterized by others and as the above stories demonstrate, phenotype combined with characterizations by others dramatically impacts on individuals' racial self-characterizations. The importance of phenotype lies in the meanings attached to such in specific contexts. In Jamaica, any visible sign of nonblack ancestry is duly noted and may mark someone as at the very least, "mixed" or "brown" and therefore, at least presumably, privileged. In the U.S. any visible sign of black ancestry is likely to mark one as black, not mixed. And, as argued in chapter five, the South Florida context creates multiple possibilities for identifications by others, which Denise and others discovered when they were frequently characterized as "Hispanic." These various characterizations may either confirm or contradict previous identifications.

Generally, participants whose previous identifications are confirmed in the U.S., continue to identify racially as they did in Jamaica, and/or to hold non-black identifications. Multiracial (black, white, Indian) Caroline is a case in point. At the time of her interview, Caroline was 42 years old and had lived in the U.S. for 19 years. When I asked Caroline how she would have characterized herself racially while in Jamaica if I had interviewed her then she said, "If I was living in Jamaica maybe I would have said 'white.' But I never thought that growing up. People have called me that. I think at that time if anyone asked me about my race I used to say 'mixed.' I have always used the word 'mixed.' I would tell them I'm mixed: black, white, and Indian." Caroline went on 
to explain that in her neighborhood people referred to her frequently as "the little white girl" or the "little browning" or the "light-skinned girl." And when she moved to the U.S. her non-black identification was confirmed by various encounters in which South Floridians assumed she was white. While Caroline claims to identify closely with her black (dark-skinned) husband and son, and while she referred to herself many times during the interview as "Afro-centric," she also stated vehemently that she continues to view herself as "mixed." Therefore when asked if her racial identification had changed since entering the U.S. she said, "No. I am a Jamaican from beginning to end. [Laughing] I'm mixed and I'm proud of it."

When participants' self-conceptualization(s), as developed in Jamaica, are not affirmed by experiences they have in the U.S., however, there is likely to be a change toward black identification. Although there were only five such cases among my participants, they are important as they serve as good examples of the impact of being characterized, and denigrated, as black; that is, of one-drop rule boundary-work. Studies of U.S. multiracials show, in fact, that both phenotype and affirmation of racial identities in social interaction are primary factors accounting for racial identity formation (Rockquemore and Brunsma 2008). Using symbolic interaction as a framework for explaining racial identity formation, scholars have argued that racial identities develop and change based on and through affirmation or negation during social interaction. Basing their arguments on the assumptions of symbolic interactionism, that not only do humans come to know things by their meanings, but meanings also develop and change as a result of social interaction, these scholars assert that identities are "validated selfunderstandings" which "depend upon confirmation from others in order to be developed 
and maintained" (Rockequemore and Brunsma 2008:20-21). Whether identities are negated or affirmed in social encounters is closely related to/inextricable from racial labels that are attached to specific phenotypical features. Rockquemore and Brunsma (2008:79) argue: "We consider appearance to be both a personal and a social characteristic; that is, one perceives their skin color, but one also interprets their appearance through the eyes of others within any given interactional sphere."

Thus phenotypical features and the racial characterizations elicited by them both in Jamaica and the U.S. have a dramatic impact on identifications that participants currently hold. It is much more likely that a participant will hold a non-black identification, if her non-black ancestry has been affirmed by her experiences in either context, but particularly if such affirmation continues to occur in the U.S. It is clear from participants' stories that their mixed physical features confuse people in both countries resulting in frequent questions like "What are you?" Especially in the U.S., these questions indicate that their phenotype makes it difficult to place them in one of the existing racial categories. These "What are you?" questions can and should be interpreted as the ways that people try to affirm boundaries when in the presence of people who do not conform to the familiar boundary categories operative in that society. People categorize and ambiguity complicates neat boundaries. The solution is to do more boundary-work to fit ambiguous people into existing categories or, more rarely but this does occur, to change the boundaries themselves. Informal Exposure: The Influence of Family: Family Racial Identity

Phenotype, like racism, is a factor that one would expect to affect people's racial identifications. Another factor that will not be surprising is family. A case in point is 
that of Deborah. As she had done frequently during her interview, 38-year-old biracial (black/white) Deborah hesitated before answering my question. I had asked what it meant to her to be racially mixed. "Wow," she replied. And after hesitating again she continued, "You know, I don't know if I could really put it into words other than to say that it is not my foremost identity. My foremost identity is that of a black woman who is culturally Jamaican and whose mother is white--if that makes sense." Deborah described her father as black and her mother as white and British. She indicated that she had characterized herself as black in Jamaica and continues to do so in the U.S. I carefully searched the transcript of her interview for clues that might explain her identification as black in Jamaica, especially given her acknowledgement that as a "brown" individual she had benefited from preferential treatment there. And it was there that I found one important clue: her family's racial identity. When asked about her family's ideas about race, Deborah responded:

I think one of the differences is that my father and my father's family are Afro-Jamaican. My great-great-grandmother was a maroon [escaped slave or descendant]. So the kinds of pejorative or negative notions that usually surround blackness were just not a part of our discourse. Because the family was black! So, yes, I have a white mother. But she married into that. So we were surrounded, in terms of family, by people who I imagine would have considered themselves black if asked. I never heard some of those typical Jamaican phrases/comments like "nuttin' too black not good" [nothing that is very black can possibly be good] or "Lawd a so him black!" [Good Lord! He's so black!] That was just not part of my family's 
discourse. But, I would say that that had to do with the specificities of my situation. And I would hazard a guess that it would have been quite different if the racial composition had been different.

Deborah's family members, the people around whom she was raised, were primarily black. According to her memories, pejorative notions of blackness were not part of her family's discourse. Conversely, they were very proud of their heritage. Her mother is white; but she had married into a black family. The combination of celebrating blackness (including historical resistance to whites as represented by her maroon relative) and being surrounded by primarily black relatives led to a strong sense of black racial identification. Moreover, she does not recall anyone ever questioning her identification as black until she migrated to the U.S.:

When I arrived in the U.S., I was required to complete the senior year in high school (there is an additional year here). My mother came with me to register for school and as we (that is, my mother, the minister for the Church who was a good friend of the family who was black, and I) are sitting there when the white registrar asked "So what race do you consider yourself?" So I said "black!" I wasn't sure what she meant or why she had asked. What else could I possibly be? And it was in that moment that I became very conscious of having a white mother. I had always been conscious of having a British mother, you know? But it was not until I came to the U.S. that I absolutely saw her as "white." And it was largely because of my experiences here. Incidents like going to the supermarket and people asking, "Are you together?" 
Deborah's story demonstrates how family racial identity can impact on one's selfconceptualizations.

Deborah had made it clear that while in Jamaica, although identifying as black, she had been very aware that she was biracial (given the fact that her mother is white). Yet, despite the fact that she was raised on an island in which racial mixtures have been idealized, her identification had always been as "black." I asked her if she had an idea why this might be so. Deborah laughed as she responded, "I don't know," she said, "other than to say that maybe some Freudian thing with my father. I don't know! But I was raised from very early to be attuned to the history and the culture and the language and the people and the music and all of that of Jamaicans." She went on to explain that her mother studied English Literature at the University of the West Indies. And during that time her mother exposed her to important literary works from the island and the West Indies generally:

...she was the one who was bringing me Ananci [African folk tales that are common in Jamaica] stories and she also shared with me the works of people like V.S. Naipaul...So you know Naipaul at that time was Caribbean before he was British [both laugh]. So again there is a degree to which because of who she was she sort of helped to reinforce that cultural identity Jamaican identity--a culture that I think is predominantly African! I mean that's what it is! There are other influences certainly, that is probably the strongest.

"Did anyone in your family ever tell you that you should view yourself as black?" I pressed. "Never." She replied. "Because it was never questioned." 
While Deborah's current identification is strongly influenced by the identity her family held while she grew up in Jamaica, biracial (black, Indian) Karen developed a sense of identification with blacks based on contact with family members in the U.S. As was demonstrated previously in this chapter, Karen is among the participants who hold multiple identifications. In her case, she understands herself to be racially mixed. As she put it, 'In reality if I'm just generally asked about my race I would say 'mixed' and on forms that have nothing to do with minority benefits 'mixed' or 'other." Karen indicated that she has taken advantage of opportunities to receive scholarships by claiming her black ancestry. But, as shown above, she realizes that in this country regardless of selfperception, she is viewed as black.

Race here was [hesitates]... Well first of all Jamaica is predominantly black; America is predominantly white. So I would say I would fall more in the bracket of being black. Once I came to the U.S. I felt more of a minority in comparison to everyone else. I wouldn't go as far to say that I was mixed. I would always say I'm black and I think it stems from hearing my mom say things like, "Those are white people." or "They're prejudiced." or "They don't like black people." So that was how I came to realize, “Oh! I'm black!”

Karen thus attributes her initial realization that she is perceived as black in the U.S. to racial comments made by her Indian mother. Her mother had lived in the U.S. for many years before Karen had migrated. Karen went on to explain that her mother's early experiences reinforced this sense that in the U.S. their family was racially "different" and treated as inferior stock. 
Like many Jamaicans my mother worked as an aid and took care of old people when she first arrived. Whenever I visited, I stayed away from them because they were old white people and they looked weird and because she'd have to assist them, I guess. But seeing her respond to these people you know, I guess in the back of my mind it was just like - in Jamaica we have helpers. So I thought, "Ok she's their helper." But I didn't think much of it at that young age. Once I got older however I analyzed that entire situation and I compared it to what I had learned about slavery. Even though slavery has been abolished on paper, it still exists in different forms. Certain kinds of people will still do the work of assisting someone with the domestic chores of other kinds of people. But now they're being paid for it. I believe that it's also an immigration issue. Some immigrants can't do better but to take these domestic jobs for legal and cultural reasons.

Karen evidently viewed her mother's low-status job as an "aid" or live-in helper to white people as the continuation of whites' domination over blacks and therefore as reflecting the remnants of slave society. She later acknowledges that this is an "immigration issue" but does not seem to dismiss the importance of race. In fact, her comment that it is for cultural reasons that immigrants take these types of jobs suggests that she sees a connection between race and the low-status employment of her mother, a connection that appears to have motivated her to identify as "black."

Family influence cuts both ways. While Deborah's black identification was largely influenced by her long exposure in Jamaica to a family that embraced its 
blackness, Karen, who holds multiple racial identifications one of which is "black," really began to identify with blacks owing to her mother's racial comments and low status job in the U.S. Biracial (black/white) Peter serves as an additional example of the impact of family racial identity on one's self-identification. Previously in this chapter, I indicated that given Peter's visible black phenotype, and his Rastafarian orientation, I had expected that he would hold firmly to black racial identification even after migration. I mentioned then that identification shift from "black" to "mixed" was intriguing. He explains the shift below:

Well, what influenced my going from being black to mixed, aside from just magic [laughs] would have to be my recent trips to Jamaica. It was that experience of seeing what a person of my racial background and complexion is in Jamaica, versus what he is here. Here in the U.S. I'm no, I don't have [privileges.] No. So what I'm saying is that in Jamaica I feel more at home amongst others who are brown or mixed or whatever. I feel like them; not ideologically, but just naturally. Personality-wise, I feel more in place. More at home I guess. Whereas here in the U.S. I had been saying that I was 'black' but I think even then I always knew in the back of my mind that wasn't really the case. I feel like I always knew that I was not really black.

Peter attributes his transition from identification as black during his early years in the U.S. to identification as mixed, more recently, to the transnational connections he began to maintain with his family. While during his adolescent years in the U.S. he had begun to strongly identify with blacks, he feels that black identification had been virtually 
forced on him in this environment - a strong example of boundary-work operating. When he began to frequently visit Jamaica in his early twenties, however, that boundary-work was not operating and he felt greater latitude to identify. He found himself identifying most closely with the "brown" members of his family and community there. In his own words, he felt "at home" when he was among them. He felt more comfortable with Jamaica's more fluid racial system. It was this recent contact that brought on a change in how he now chooses to identify racially as expressed in how he completes forms that collect racial information.

\section{The Influence of Family: Socio-Cultural Interaction}

Peter's brother, Damian, though also biracial, described his father as black and his mother as Chinese. Damian indicated that he had never thought of himself racially while in Jamaica. He left Jamaica for Canada while still young (at the age of 12 or 13) and moved to the U.S. 18 years later, that is, at age 30. I asked Damian how he would have characterized himself racially if I had interviewed him then and he replied, "As a Jamaican." Then I pressed for a racial identity by asking, "When asked to select a category on a government form then, what did you select?" He replied, "I put black." And when asked how he currently identifies on forms he said, "I think I put black. I don't check other." I probed further, "At times there is a difference between what racial category individuals select on forms and the ways in which they perceive of themselves. Would you say you see yourself as black, as mixed, as Chinese?" He replied, "My conditioning is that of a Chinese Jamaican person. And being Jamaican obviously brings along the black culture with it. So I think I see myself as a Jamaican first. And again this 
is about the whole race thing. I really don't care about race. It's the culture that I am more focused on."

For Damian, the answer to my question was complicated. His first impulse was to want to avoid race completely by identifying only as Jamaican. Yet when asked to think specifically about race, he evoked his Chinese ancestry. What seems important to him is being both Jamaican and Chinese. And while he also acknowledges his black ancestry, his comment, "being Jamaican obviously brings along the black culture with it" seems to render "black" as less important. That is, when asked how he views himself racially (versus what he writes on forms) at no time does he apply the label "black" to himself. It was also interesting to me that he refrained from either using a blended term such as "mixed" or from referring to himself as both black and Chinese. I suspected that when he thought about "race" [or racial identity] his Chinese ancestry, in his opinion, was more salient. And, of course, I wondered why.

I found the answer during several opportunities in which I was able to observe Damian after this interview. One such opportunity was the wedding of his brother, Peter. I noticed that Damian made repeated references to himself as a "Chiney" [Chinese] and, in particular, that he tended to make assertions about the "virtues" of Chinese Jamaicans. Peter's new bride is second-generation Jamaican and biracial (black/Chinese). During Damian's toast to the couple he lauded the bride's various qualities, emphasizing "thrift" and "industry" as typical Chinese traits. These observations confirmed my suspicions about the importance of Chinese identification to Damian. While understanding that based on the U.S. racial worldview he is considered "black" here, and despite acquiescence at the very least when completing forms, Damian identifies most closely 
with his Chinese ancestry, and while neither necessarily denying nor renouncing his black ancestry, he seems not to assign it much importance as, for him, blackness is automatically linked with Jamaican culture.

My conversations with both Damian and his brother, Peter, provided additional clues about the factors that might explain Damian's strong Chinese identification. Peter explained that Damian had been raised by his Chinese grandparents. Damian confirmed that fact noting that this meant exposure to Chinese culture, "I was exposed to family discussions about racial identity because like I was raised in a predominantly Chinese home in Jamaica. Also I would say maybe fifty percent of my friends were Chinese. And as you might expect, their parents would come over our home, and we'd go over to their house and we would pick lychees and do all the typical Chinese things." He continued, "My grandmother always wanted me to marry a Chinese woman. Definitely not white. She never had any strong opposition to black girls, but whenever marriage came up in a conversation she would say, 'Why not marry somebody like this person?' and it would always be the case that she was referring to a Chinese girl. I was also exposed to lots of Chinese slang." What neither Damian nor Peter say is that Chinese have come to hold a position of some prestige in Jamaica's social hierarchy. Thus being Chinese likely holds strong significance as a status symbol for Damian. His comments about Peter's wife certainly suggest that he associates positive traits and habits people of Chinese ancestry. And the comments about his grandmother's boundary work document how effective it was on him.

Damian's exposure to various aspects of Chinese-Jamaican cultural habits and to race talk about their Chinese identity impacted on the way he viewed himself racially, 
and continues to do so today. Note also, that as shared in the last chapter, Damian is among participants who while having been racialized as black in certain contexts in the U.S., have also been characterized as non-black (in his case, as Filipino and Hispanic.) Encounters such as those likely also served to reinforce his non-black identification.

Damian's case demonstrates how family can influence racial identification through enculturation. And the impact of such enculturation on the formation of racial identifications should not be understated (Clinton 2006, Roth 2005.) Roth (2005: 43) has argued that multiracial individuals who display a stronger connection to a specific racial group, may do so due to, “...exposure to aspects of that group's culture or heritage, leading to a positive association with the group. This cultural connection may shape racial identification, and this may be called a cultural conformity model of identity. Roth explains what while one's cultural heritage is generally linked with ethnicity (more so than it is with race) rarely do individuals distinguish between the two in their daily lives.

My data indicate that among participants with Asian ancestry, social interaction that involves performance of cultural rites that are linked to their Chinese or Indian ancestries, dramatically impacts on individuals' self-identifications. Damian's exposure to Chinese culture through his family and friends evidently caused him to forge a strong sense of identification as “Chinese." Multiracial (black, Indian, white) Garry, who has had various racial encounters and has been victim of racial slurs (such as "Nigger") likely due to his dark skin complexion is an additional example of participants who, despite being racialized as "black," continue to hold non-black identifications, in his case, as "mixed." Garry told me that in Jamaica he had identified as "mixed." When asked why that was so he replied, "I think it has a lot to do with culture. My family on my mom's 
side observed many Indian traditions. Each year there were several events. We attended at least one event each month. And at each event we would always have traditional Indian dishes and spend time with her family most of whom live in [a certain parish ${ }^{24}$ in Jamaica] in which there is a large Indian population." I asked Garry to provide examples of such Indian cultural events and he responded by saying, "Well in Jamaica there was an event called Hosay which had the main purpose, I guess, of honoring one of the Indian gods. So they would build this float that was supposed to represent bad spirits. They would march with it a few miles down to a river and then they'd throw it over the river to signify washing away all the evil spirits."

As Garry explained the event to me he seemed unclear regarding details of the special meanings attached to it. I asked him to spell "Hosay" and he admitted he did not know how to do so. Despite not being fully versed on the meaning behind the event, it is one that provided him with close connections to what he knows as "Indian culture" and one of the activities to which he attributes his "mixed" racial identification. He continued, "Once a month we would meet with my grandparents in the country and have traditional dishes like dahl pourri and roti and pumpkin takari. So that's why I identify with Indian culture since these are not practices that all Jamaicans have."

As Garry spoke about his current identification as "mixed" he said, "And I am aware that whereas you have more of an identity in Jamaica as a mixed or whatever, once you come here you're no longer mixed or whatever. You're black, or white, or Hispanic. No in-between. So that's one of the reasons why I still enjoy hanging out with family at these Indian festivals. They allow me to enjoy what makes me a little bit unique. I think

\footnotetext{
${ }^{24}$ Jamaica is divided into 14 political subdivisions known as "parishes."
} 
everybody has that little bit of desire in them: to want to be a little unique.” Thus Garry continues to view himself as racially mixed largely due to his exposure, through family members, to various cultural practices celebrated by the Indian community in Jamaica. And in the U.S. context, he has continued to attend similar events in order to preserve his sense of connectedness to his Indian ancestry.

The above stories demonstrate that socio-cultural interaction with family and friends, both in Jamaica and in the U.S., impact on participants' racial self-identifications of my participants. These interactions are varied, ranging from being raised by family members who held a particular racial identity (black in Deborah's case, Chinese in Damian's) to characterization by others and/or racializing experiences in either location, yet they are all correlated with identification outcomes in the U.S. Participants with Asian ancestry who have been exposed to cultural practices linked to Chinese or Indian traditions are much more likely to hold blended or, perhaps, Chinese/Indian identifications. And even if racialized as black in the U.S. these people may, like Garry, seek to continue association with their Asian cultures in order to preserve their blended identifications.

The most prominent factors influencing racial identifications of my participants are therefore racialization and racism, phenotype, characterization by others, and sociocultural interaction, especially with family. Of these factors, the most salient is phenotype particularly given the fact that phenotype interacts with and leads to racial characterizations. An additional factor that appeared, initially, to be important is gender. Further analysis of the data, did not, however, support these early suspicions. That is, I 
could find not clear link among my participants between gender and racial identification choices.

\section{Choice or No Choice? The Impact of Structure on Agency and Vice-Versa}

An important implication of the argument that both phenotype and racial characterizations imposed by others affect mixed-race Jamaicans' racial identifications is that it suggests that individuals have no choice in the racial labels that are assigned to them. Indeed, the stories shared above describing the impact of phenotype and sociocultural interaction on participants' identifications, suggest just that. Since race and racial identifications are socially constructed, the meanings attached to phenotypical differences in specific contexts may impact to varying degrees whether an individual feels free to choose a racial identification or not. Thus, the racial identifications that my participants held in Jamaica were a function of their physical features, the socioracial hierarchies operative in Jamaica while they were in their formative years, their family and friends' influences, the meanings attached to race categories in the Jamaican context, and their own agency.

Rahier (2003) describes the impact that the different meanings ascribed to his ambiguous phenotype in different contexts have had on his racial identifications in Belgium, Ecuador and the U.S. The son of a white Belgian man and a black, Congolese woman, Rahier was dubbed, metis (mulatto) in Belgium, negro fino (educated black) in Ecuador, and "black" in the U.S. Each label reflected commonsense understandings shared within the three cultural contexts. As he put it: 
Race is, indeed, a floating signifier: it means different things, at different times, in different places. While in Belgium I have always been treated, in one way or other, as an outsider, as a foreigner. Strangely enough most Ecuadorians have been unable to think of me without locking me up into Belgianness, despite the fact that. . .I have found myself unable to embrace fully or claim Europe as my own. (Rahier 2003:101)

For Rahier, there was little choice permitted him in either context as far as racial self- identification. Recounting his first racial encounter in the U.S., Rahier shares the consternation he felt when, unaware of the one-drop rule and the various types of boundary work that perpetuate it, he referred to himself at a social gathering as "mulatto" and was accused of rejecting his "blackness." "I would have liked to clarify to my interlocutor at the barbecue that where I grew up, I was left with no other choice by to self-identify as a métis," he continued, "that in order to claim 'blackness' for myself, that is to say, to claim 'Africanness,' I would have been expected to demonstrate -in addition to having darker skin -the particular cultural knowledge that comes along with such an identity." (2003:102)

My data provided much evidence that, like Rahier, some participants felt constrained by external forces to identify racially in specific ways. Biracial (black/white) Brian, is a case in point. Brian, who describes his mother as black and his father as white, in my estimation appeared to be white based on his blond hair, blue eyes and very fair complexion. As shown in chapter four, Brian's phenotype had earned him experiences of extreme racialization and, paradoxically, exclusion in the Jamaican inner city community in which he was raised. While Brian wanted very much to be accepted as 
a member of his community, his phenotype marked him as an outsider in Jamaica where people overwhelmingly can claim African ancestry. Brian is the only participant who had held white racial identification both in Jamaica and in the U.S. I asked Brian for the bases upon which he had characterized himself as "white" in Jamaica and he replied, "Oh my physical features: the pigmentation of my skin, my eyes, my hair. I could not tell anybody I was anything else." Brian feels that due to his appearance, he has not to be able to choose a racial identification. That is, he had no option but to characterize himself as "white." He was completely bounded.

Thus some participants, like Brian, felt constrained by external factors (such as phenotype and the racial labels linked with such in both contexts) and do not test these boundaries drawn around them. Yet there were also several participants who demonstrated a great deal of agency in the construction of their identifications in this context. Some participants constructed racial identifications in defiance of structural factors that might otherwise constrain them. Among these participants was 22-year-old Cynthia. Cynthia, who had lived in the U.S. for six years, described both her parents as mixed. She described her maternal grandfather as "Scottish Chinese" and her paternal grandfather as "black Indian." When asked how she had identified racially in Jamaica, she replied, "Black. That's what people see.” As I studied Cynthia's features I found myself agreeing with her. In my estimation, she was dark-skinned and her full lips and kinky hair gave me no indication of her mixed racial ancestry. But when asked about her current racial self-identification Cynthia indicated that she identifies as "mixed":

When I first came to the States I was black. But I have started to become upset when people ask me what race I am or when I am filling out an 
application about race, because I feel like I can't just be whatever you want me to be. Who are you to tell me what I am? I can be white, I can be Chinese, I can be black. I can be whatever is in my blood. I could be any of those. You can't tell me they are not in my blood because they are. But what you see is what you want me to tell you and that is frustrating for me. I tend to shy away from those conversations. But when I do speak about race, I do tend to say that I am mixed. At first I use to say "black," then it became "Jamaican." Then I would say "Jamaican black." But now I classify myself as mixed. I'm mixed and I'm happy to say I'm mixed. Thus, despite Cynthia's appearance which bounds her as black in contexts, she now adamantly identifies as mixed. And she does so in defiance of her phenotypical features and the meanings attached to them both in Jamaica and the U.S. Focus group participant, Lissette expressed similar views. Lissette who is biracial (black/white) shared that while in Jamaica, she had identified as black, largely because of a conversation with her mother in which the latter told her she was black. While she claims never to have questioned her mother's characterization of her as black during her years in Jamaica, more recently she has begun to do so. Lissette was among the focus group participants who currently identify as "mixed." While she does not explain the reason for her current characterization, she states adamantly that she refuses to be defined by others. As she put it, "I decided that I was not going to allow these people to define me. I am going to define myself." Lissette had herself been racialized as black in the U.S. She shared the following incident that had occurred shortly before the discussion in Texas: 
I've been here for 17 years and when I first came the racial issue was stark. I think that things have changed somewhat so I had kind of forgotten about the race issue, except for when I have to complete a form that asks about race. Then it's like, oh my goodness: this again! However, we are moving to Texas and I went there about two weeks ago to try and find somewhere to live. I drove around with this white realtor, with blond hair, who was showing me apartments. As we drove we chatted and he asked if I spoke Spanish I said "yes" and he asked where I was from and I said, "I'm from Jamaica.” And he said, “Oh you're Jamaican!” And he said, "You know my dealer is Jamaican. He's married to this Dutch woman. And I was like, "Oh that's great." And then he said, "And he has a lot of dark-skinned children just like you. [Incredulous laughter] And [still laughing] and man it was a weird moment! I didn't know what to do. And it, my race, hit me then. For the first time in many, many, many years, I thought, "Oh! Maybe I'm dark-skinned compared to the rest of you."

For Lissette that encounter threw off any blinders to the one-drop rule she had worn in the U.S. However, it also appears to have motivated her to resist the very boundaries drawn around her, launching her into insisting that, despite her unambiguous appearance, she was going to assert an ambiguous, "mixed" identity.

Another participant who demonstrates agency in identity construction is multiracial (black/white: Italian, Mexican, Lebanese) Patrick. Patrick had had various racial encounters and had been the victim of racial slurs (such as "mule") likely due to his dark skin complexion. Like Garry, whose story was shared above, Patrick has continued 
to adamantly identify racially as "mixed." While Garry attributed his mixed racial identification to exposure to Indian cultural forms, Patrick made no mention of exposure to cultural expressions linked to his Lebanese, Mexican or Italian ancestries. I therefore searched his transcript for factors that might explain his mixed identification. Though dark in complexion, Patrick's phenotype (facial features and hair type) were in my estimation European rather than African. He noted that his physical features have elicited "What are you?" questions in the U.S. context. Patrick is evidently among participants who have experience both racialization as black (and in his case, racism) and racialization as not black. It is my belief that the latter served to affirm his mixed identification. Therefore, while Patrick has been bounded as black through his experiences with racism, structural forces do not determine a particular racial identification. Though the "What are you?" boundary work tries to continually place him into existing, neat U.S. racial categories, he does not succumb.

Scholars (Brettell 2007, Glick Schiller and Fouron 2001, Jaynes 2004, Portes and Stepick 1993, Sibley 1995, Stepick et al. 2001) have argued that immigrants encounter boundaries that constrain their lives and their identification choices. Moreover, encounters with boundaries that prevent their full social inclusion on racial or cultural grounds are disturbing for immigrants (Hintzen 2001, Portes and Stepick 1993, Sibley 1995). In the previous chapter, I argued that my participants face racial borders in the U.S. that they believe limit their full inclusion into the American mainstream. In some cases, these racial boundaries both determine and restrict self-identifications. Yet, it is also true that these racially mixed Jamaicans have not only been defined by others owing to their ambiguous phenotypes and ancestries, but they have found ways to take 
advantage of the same ambiguity and/or to resist others' boundary- work toward them. The question which remains, however, is whether or not mixed race Jamaicans are only responding to boundary-work others do or if they, themselves, engage in boundary-work and, if so, what do they do and why?

\section{Mixed-Race Jamaicans Doing Boundary-Work}

Taking an agency lens to the stories told in this chapter so far reveals that participants are engaged in boundary-work. Two levels of boundary-work are at play here: there is boundary-work at the structural level as demonstrated by already existing racial borders for categories that are patrolled to mitigate others from crossing from one category into another. The effect of this patrolling, as shown in these last two chapters, is participants feeling boundaries being drawn around them. And there is the transgressing form of boundary-work shown by participants trying to carve out new or revised — and especially mixed (since these are unsettling to category makers)--identifications for themselves. To this point I have focused primarily on how mixed race Jamaicans "encounter" the one-drop rule in the U.S. When they encounter this rule, they find the boundary-work applied to them and they react to it. In a sense, the boundary-work they experience tries to draw them into the black/African American identity in the U.S. It is thus at once inclusionary (you are black, you belong to black in the U.S. racial world view) and exclusionary (you are black so you belong at the bottom of the racial hierarchy). In this section, however, I will also document how Jamaicans themselves do boundary-work. This is tricky boundary-work since in many cases it embraces blackness while holding at bay the African-American moniker. 
The main point of this section of the chapter, then, is to highlight how mixed race Jamaicans who so ardently dislike the boundary-work they perceive done against themparticularly but not uniquely in the U.S. - nonetheless actively engage in the very boundary-work of which they are so critical. Moreover, while they certainly perceive the boundary-work of others on themselves, they appear to be unaware of their own efforts. Why would they not see in themselves what they see in others? It has already been shown that scholars of boundaries attribute boundary-work to a human propensity for categorizing. As Massey (2007: 10-11) puts it, “All human beings, whether they think of themselves as prejudiced or not, hold in their heads schemas that classify people into categories based on age, gender, race, and ethnicity...They cannot help it." Indeed, scholars argue that it is so "natural" for humans to categorize phenomena (including people) that children begin to classify humans based on race in their preschool years (Hirschfeld 2005, Massey 2007). Hirschfeld (2005) writes that while toddlers display color-blind attitudes in the choice of playmates, they begin to discriminate based on race and exercise prejudice starting around age 3 or 4 . They begin to consistently associate negative behavior with blacks but positive behavior with whites - evocative of the famous doll studies done by Kenneth and Mamie Clark in the 1940s in the U.S. The Clarks offered young black children the choice of a black or white doll to play with and most chose the latter. When asked why, the children responded saying that the white doll was pretty and the black doll was ugly. Kenneth Clark testified about the research during the Supreme Court hearings on segregation and contributed to the infamous Brown v. Board of Education ruling outlawing segregation by race in 1954 . 
While this dissertation does not focus on children, the research with children helps explain the behavior of my participants. If, as Massey (2007: xv) writes, "inequality is rooted in the human proclivity to think in categorical terms," then since in the U.S. social status is organized primarily based on race, individuals are likely to seek to carve out identifications that do not carry negative social stigma (or else to erase or transform pejorative notions about denigrated racial groups). All of my participants have African ancestry; and most bear some phenotypical features (skin tone, ambiguous features) that indicate their black ancestry and that therefore make them susceptible to racialization in this context.

As the stories in this chapter demonstrate, my participants actively sculpt selfidentifications in response to feeling bounded within the U.S. racial system. While very few interviewees indicated outright rejection of racial labels in favor of identification as "Jamaican," more than one quarter (26.5 percent) preferred an ethnic over racial identification. Multiracial (black, Indian, white) Paul is among interviewees who reported rejection of racial labels in favor of identification as "Jamaican." Paul, who was 26 at the time of our interview, had lived in the U.S. for 15 years. In my estimation, there was little to indicate Paul's non-black ancestry; he was dark in complexion yet with a few ambiguous facial features. Paul declared that he had not thought about race or racial identity in Jamaica and that he currently identified as Jamaican. He explained that he feels culturally different from Americans, "I think if you're Jamaican then you have a cultural kind of bond with each other. I would separate myself from being American. I feel more...I don't know if you want to say 'American-Jamaican.' But I would say I am 
Jamaican. I'm a Jamaican person. My family is Jamaican; we have our own culture. And I'm proud of that."

The recent "I am Caribbean" web-based Census 2010 campaign is a reflection of this ethnic sentiment among West Indians. In a notice that was distributed by e-mail and posted on several Jamaican-American websites, people with Caribbean ancestry were encouraged to identify their country of origin on the 2010 census form. The letter publicizing this campaign cited Sheldon Mundle, president of CaribLifeCentral.com, who stated that underrepresentation of Caribbean Americans in the census has, "adversely affected our community in terms of quality of education and business investments...In question 9 of the Census form, individuals are allowed to identify themselves with multiple racial origins," explained Mundle. "We are encouraging people of Caribbean ancestry to exercise this option by also selecting 'Some other race' and writing in their nationality." ${ }^{25}$ I made several attempts to contact Mr. Mundle and learn more about the campaign. Although I am myself Jamaican, I was uncomfortable with the idea of selecting "some other race" and writing "Jamaican." As I saw it, the label "Jamaican" might represent ethnic identification; but it certainly did not represent a "race." While I was not able to reach Mr. Mundle, I noted that in their Facebook status updates, several of my Jamaica friends posted comments encouraging West Indians to support the campaign. Virtually every comment indicated that completing the form by selecting "other" race and filling in the accompanying black with "Jamaican" was the only way of ensuring that Caribbean Americans are counted by the census as a separate group. In the

\footnotetext{
${ }^{25}$ I received this notification by email from a family member. The letter directed readers to http://www.cariblifecentral.com/page/i-am-caribbean for additional information on the campaign.
} 
theoretical framework of this dissertation, the census campaign can and should also be viewed as doing boundary-work among people of African ancestry against their categorization with African-Americans.

Such boundary-work is not new. Several scholars (Brettell 2007, Foner 2001, Hintzen 2004, Rogers 1999, Vickerman 2001) have shown a marked tendency among West Indian immigrants to hold ethnic rather than racial identifications. Some of these researchers (for example, Brettell 2007, Rogers 1999, Vickerman 2001, Waters 1999) argue that while ethnic identifications serve as "alternative self-definitions" for West Indians, and while many hold their West Indian ethnicity as their primary identification, they largely see no conflict between ethnic and racial identifications (as black). That is, the fact that West Indians seek to distinguish themselves on ethnic grounds, is not necessarily an indication of outright rejection of black racial identification. It is certainly true that ethnic identification does not completely rule race out for some of my participants. Of the nine interviewees expressing strong ethnic sentiment, six also reported racial identifications.

The difference is that most of my participants hold racial identifications as "mixed" or "multiracial" (or Chinese); and some do not at all view themselves as black or of African ancestry. In the case of these racially mixed yet non-black Jamaicans, then, they have to do a different form of boundary-work; they have to assert their membership in an identity be that identity "Jamaican" or "mixed" or another. That is, in the U.S. context they do not neatly fit into any given race category so they must find ways to transgress those borders; but they enjoy more options than their compatriots of African ancestry who feel the weight of the one-drop rule pressing hard upon them. The 
experiences of these mixed race West Indians is not really discussed in the existing literature.

Regardless of whether they hold African ancestry or not, mixed race Jamaicans I researched engage in boundary-work to reinforce the divide between themselves and African Americans. The vast majority (76.5 percent) reported having primarily West Indian friends. Only seven (20 percent) reported having African American friends. Participants who reported having no African American friends were asked to explain why. Most seemed unsure of the reason; some explained that their socialization had not exposed them to African Americans. The following conversation with biracial (black, Indian) Kevin exemplifies these responses:

Q. Do you have any close African American friends?

A: [Laughs] I honestly can't say that I do.

Q: And can you think of why that might be so?

A: Well when I was in school I had a couple of African American friends and we were pretty close. I was particularly close to one named Dave, and he was a great guy. Even though, I have a stigma about African Americans in general, I thought he was great guy: very intelligent, very talented. But I can't say why I don't have any close African American friends. I guess, just haven't in most of my interactions. At work most of the people are white. There aren't any African Americans at work. And at church, even though it's a mixed, most members are white or Caribbean.

Kevin seemed either unable or, perhaps, unwilling to explain his lack of social engagement with African Americans. But I found a possible explanation elsewhere in his interview. While explaining why he initially selected the "other" category on forms in the 
U.S. he said, "I had a stigma about African Americans and on the forms it usually just says African American and probably Asian, white. I really didn’t identify with African Americans." Kevin was referring, here, to his earliest years in the U.S. It is likely that those negative notions had not changed by the time of our interview.

It is clear from study participants' various comments and their often caustic critique of African Americans that many hold negative impressions of them. Chapter five outlined some of these impressions. For example, Jamaicans, like other West Indians, quickly learn about the low social status that people of African descent hold in this country. African Americans bear the brunt of this social stigma. Jamaicans with black ancestry thus seek to find ways to distinguish themselves as different. In part they do so because they perceive strong cultural differences based on their West Indian upbringing. But, as the following comments by multiracial (black, Indian, Chinese) Tracy demonstrate, it is also clear that, in some cases, participants make these distinctions on racial grounds:

I think there is more freedom in Jamaica to just be mixed and not to identify with one race versus another. One thing that I have had to make very clear to people that I meet here is that I don't identify with African Americans. Someone who is from a West Indian island is very different and just cannot identify with African Americans. I think it's very difficult for Americans to understand that.

Other participants explicitly expressed their desire to disassociate themselves from African Americans to avoid negative social stigma. Multiracial (black, white, Indian, Chinese) Andrew expressed such views while describing family discourse about race, 
"We will talk about the fact that we are seen as black in this country and how we want to make sure that people don't see us as a stereotypical black person, because a stereotypical black person is a negative stereotype. We need to avoid the stereotypical black thing. I think that we come here and we achieve a lot more in a shorter span of time than they have achieved as a group, so I would rather stick with the group that has been more successful."

In seeking to distinguish themselves from African Americans, regardless of the specific reason for doing so, participants are clearly drawing boundaries around themselves. Indeed, as Jaynes (2004: 107) has shown, Caribbean immigrants with black ancestry intentionally "retain audible and visible markers of their Caribbean ethnicity to differentiate themselves from African Americans. By doing so, they signal to employers (presumed to be negatively screening African Americans) that they are 'good blacks."'

Although it was clear from participants' responses that the overwhelming majority had close friendships with primarily West Indian individuals, only one respondent, biracial (black, white) Peter volunteered an explanation. When asked about the races of friends he had made in organizations or clubs, Peter replied, "Black. They are actually black Jamaicans. The black people who are in this group are mostly Jamaicans." I asked, "Do you think that you have become close to them because they are Jamaican?" "It is definitely because they are Jamaican!" he replied. "I'm very biased in my friendships. I like to be around people that I'm like." While Peter was the only respondent who specifically expressed the desire to forge friendships with individuals based on racial or ethnic similarities, participants' actions suggest a common preference for such. That is by their choice of primarily West Indian (often racially mixed) 
individuals for social interaction, participants are demonstrating a preference for their "own kind."

It is important to clarify that the tendencies of my respondents to carve out nonblack identifications and to hold primarily "West Indian" friendships, do not in every case indicate a desire to disassociate themselves completely from all African Americans. Nor do they necessarily indicate a lack of concern for or compassion for people of African descent. While several participants expressed the explicit desire to distinguish themselves from African Americans for various reasons, several others demonstrated the desire to identify with this group. Those who chose to identify with and not against referred to common racial causes and/or showed that they understood that African Americans had endured different circumstances and therefore have different notions about the social significance of race.

As argued before, scholars (notably, Benson 2006, Rogers 2001, Vickerman 2001) have shown that due to shared experiences with racism, West Indians do eventually develop a shared sense of common interests with Africans Americans. Hintzen (2004:298) writes that people of African descent are united by a Diasporic identity "in a global web of racial intimacy. It occupies the sentimental center in black trans-national political alliances employed so successfully in the various nationalist struggles against colonialism and racial segregation. It has served as the cement that has tied black immigrants and African Americans together in political alliances aimed at breaking the strictures of white exclusivity and privilege both in the United States and in the countries of origin of black immigrants." The sense of an African Diasporic connectedness is echoed in multiracial Christine's explanation for her current identification as black 
(shared earlier in this chapter but repeated here for emphasis), "I think it's important to identify with the Diaspora." She said. "We have a huge African Diaspora outside of Africa, that forms a voting bloc, and this is the bloc that I'm driven to identify with: African Americans and Afro-Caribbeans and other part of the Diaspora. We are a huge voice."

The sentiments shared by Christine and Patrick do not, however, represent those of most of study participants. By and large, my interviewees were both critical of, and anxious to avoid association with African Americans. And in so doing, they were performing boundary-work.

The boundary-work done by Jamaicans is not, however, limited to the carving out of racial identifications, or to the drawing distinctions between themselves and African Americans. They also do boundary-work among themselves - often quite unconsciously. Several examples appear in the data and I share a few here. Among them is the use of color terms by participants even when not prompted to do so. Multiracial Andrew, for example, while rejecting the idea of race admitted he was much more comfortable with Jamaicans' emphasis on skin shade. Interestingly he demonstrated this preference as he described his closest friends to me:

Q. How would you describe Jim racially?

A. He's mixed as well. But he's a little darker than me.

Q. He's mixed but darker.

A. [Interrupting] Well a little darker. He is just a little darker than me.

Q. You mentioned that he is racially mixed. Do you know what are his racial ancestries? 
A. He would have African and white in him too. So he's black and white.

Andrew might have simply chosen to describe his friend Jim as "mixed." That he emphasized his skin complexion, even sought to compare Jim's complexion indicated to me that making distinctions by gradations in skin color remains important to him. Biracial (black/white) Audrey showed similar tendencies when she described her racially mixed friend, Dawn, as "high-color." Her use of "high-color" rather than "brown" (the color term she applies to herself) was striking to me because, more so than "brown," "light," or even "fair," "high-color" reflects that higher value attached to fairer skin. If a person with a very fair complexion is "high" then dark complexion is "low." Audrey seemed to use the term "high-color" automatically and her experiences in Jamaica explain her automatic use of the term. Color terms ("red," "high-color," "yellow") she explained, were used frequently in her family. She had explained that, "the lighter your skin color was the more beautiful or more favorably you were seen. The darker the skin color, the less favorably you were seen. So even while we were still children we were tended to want to have only the lighter skinned children as friends." Color-based boundary-work in the choice of friends, then, had been the habit even during her childhood.

An additional example of participants doing intra-Jamaican boundary-work was multiracial, Caroline, whose stories were shared in both chapters five and six. While insisting that she and her husband are the "same," that is, Jamaican, Caroline repeatedly distinguished herself as "mixed." In fact, when asked if her racial identification had changed she replied, 'No. I am a Jamaican from beginning to end. I'm mixed and I'm proud of it." It was interesting to me that she so wanted to identify with her dark-skinned 
husband but that she held firmly to her ethnic "Jamaican" and "mixed" non-black racial identification. That is, it seemed to me that she avoided the label, black. Thus while interviewees insist that Jamaicans do not hold race as important and while they are very conscious of racial boundary-work done to them in the U.S, they seem much less aware of how they participate in racial boundary work -- not just towards African Americans but also towards each other -- in Jamaica and in the U.S.

\section{Chapter Conclusion}

The histories of race in Jamaica and U.S. show that when people are dispossessed by the boundary-work of others, they make great efforts to dismantle barriers to their social mobility. This has been no less true for my participants who, in encountering boundary-work here, have looked for ways to counter the exclusion it engenders. I set out in this chapter to describe how my study participants respond to rigid racial boundaries and the boundary-work that enforces them, in the U.S. Their response, as might be expected, is essentially to seek to carve out various self-identifications. While survey data indicate a clear preference among participants for ethnic "Jamaican" identification over any racial label, few interviewees expressed such a preference. Most interview participants were, in fact, holding racial identifications, and the majority of those doing so were holding non-black identities as "mixed" or "multiracial." In some cases participants current self-identifications are expressed as having been forged in response to external forces (such as existing racial categories and the border patrolling by which others in the U.S. seek to fit them into specific categories). In other cases, structural or external forces (such as phenotype) permit or facilitate the choices they make. And in still 
others there is evidence that participants are intentionally choosing identifications that they feel fit their own self-conceptualizations in defiance of both existing categories and how they are characterized by others.

Regardless of participants' current self-identifications (ethnic or racial, black or non-black) they are all conducting boundary-work. As human beings, they have all been exposed to boundaries and boundary-making, and all are naturally inclined to categorize as well. In Jamaica, boundaries were based primarily on class (rather than race). Thus their encounter with a social system in which race permeates every sector of society, as well as with rigid racial boundaries and border patrolling, has proven disconcerting for my participants. Yet, in responding to their encounters by carving out new identifications that distinguish them from others, they are, indeed, also themselves, carving out boundaries. One might argue that the U.S. racial system leaves them no choice. To what degree can they avoid racial categories given structural forces that demand racial categorization? Is it really fair to conclude that they are doing boundary-work? Can they refuse to think about race or ethnicity in a society that is still very much organized based on race? Yet the data show that participants are not merely responding to racial categories on forms. They are rather making deliberate "choices" given certain constraints. They do boundary-work in their attitudes toward African Americans, specifically in their expressed desire to distinguish themselves as "different." They do boundary-work by carving out friendships that are primarily West Indian or Jamaican, and in many cases with individuals who are also racially mixed.

Racial boundaries were erected in the U.S. by the dominant white elite in order to establish and maintain a status quo that privileged its own members. And for centuries 
the border between whites and non-whites were carefully patrolled (by whites). Yet, as has been shown, in both Jamaica and the U.S., subordinate groups including racial minorities, albeit for different reasons, have themselves conducted their own type of border patrolling. And while my participants have expressed consternation at their encounters with boundary-work in the U.S., their response has been to participate, quite likely, unconsciously, in the very boundary-making about which they have been critical. 


\section{CHAPTER VII}

\section{Conclusion}

This dissertation was designed to explore the impact of U.S. constructions of race on the racial self-characterizations of racially mixed Jamaican immigrants. Of specific interest was the impact of these Jamaicans' exposure to the U.S black/white racial binary system, buttressed by the one-drop rule, which has historically restricted racial identifications for people with black ancestry. Using the boundary-work theoretical framework, the dissertation describes the social construction of race in both the U.S. and Jamaica. It shows that because the countries evolved different constructions of race, mixed-race Jamaican immigrants enter the U.S. with ideas about race and racial identifications that clash with the U.S. racial worldview. It highlights, in particular, their response to rigid racial categorization and the one-drop rule. In focusing on racially mixed Jamaicans, it highlights the special experiences and perspectives of a group of West Indians not emphasized by the existing literature.

\section{Findings}

While in both the U.S. and Jamaica the dominant white elites constructed rigid racial boundaries by which the societies were stratified, different processes of boundarytrangression, -blurring and -shifting have resulted in the development of more fluid notions of race in Jamaica. There, color has replaced race in a complicated color hierarchy that now draws boundaries that are more blurry than bright. The blurriness of those boundaries that characterize that hierarchy implies permeability and flexibility for all. That is, the blurriness of Jamaica's boundaries also implies that neither race nor color 
is rigidly connected to social stratification in that country. Moreover, as they are both racially mixed and middle-class Jamaicans (and, not not unimportantly, part of the postIndependence generation) my interviewees largely eschew race as significant in Jamaica. They attribute Jamaica's post-racial state (as they see it) to two primary factors: (1) class has surpassed race as the primary means of social distinctiveness on the island and (2) the national motto "Out of many, one people," has been inculcated in Jamaicans so that the society is characterized by virtual racial harmony. They argue, in fact, that the motto is responsible for the Jamaican acceptance of race mixing and that it also reflects what is an actual fact (in their view): that Jamaicans are "one" under the banner of nationhood.

My participants' memories of Jamaica confirm arguments by Vickerman (1999) that as a result of Jamaica's nation-building project, race consciousness has been muted in Jamaica. Indeed Johnson (2005) has shown that the muting of race consciousness in Jamaicans had been the specific goal of the state of Jamaica's leaders as they took the country to Independence. But participants' stories also show that a great deal of racial concern still permeates sectors (especially the urban and rural black poor) of the society, albeit concern they are unaware of. And in so doing, they confirm the argument of Johnson (2005) that post-colonial Jamaica is to some degree still shaped by racial contours.

Despite participants' assertions that race and color have been decoupled from class, it is clear from their stories that color still holds strong symbolic value in Jamaica. Light complexions are still valued over dark complexions. Color moreover signifies social status: higher social status is accorded Jamaicans with lighter skin (and non-black hair and facial features); the reverse is assigned to those with darker hues. I argue that 
color draws both symbolic and social boundaries in Jamaica. Rarely does color explicitly impact upon peoples' chances for social mobility or their daily experiences. That is, it is not likely that either race or color will affect one's access to employment, professional growth, academic success etc. But the symbolic value color holds often leads Jamaicans, especially the poor urban and rural black population, to link race and/or color with limited opportunities. It is thus the symbolic boundaries drawn by color that are deemed important here. The fact, however, that for many poor Jamaicans color signifies social status, sometimes leads to boundary-work on their part. A case in point is the experience of biracial (black/white) Brian - the participant who was racialized and excluded by members of his inner city community in Kingston, Jamaica. That is, for Brian, color sometimes functioned as a social boundary which affected his daily experiences. Moreover, as is demonstrated by persistent Afrophobia in Jamaica's beauty contests, and by participants' stories of brown privilege, symbolic boundaries, translate into social boundaries.

In fact, Jamaica's color hierarchy generally affords mixed-race Jamaicans relative privilege, vis-à-vis unmixed (or dark-skinned) blacks. Therefore, despite study participants' assertion that race is not important, most have really benefitted from the value that is attached to skin color in the Jamaican context. They do not, however, enjoy the same advantage in the U.S. where gradations in skin complexion among people with black ancestry make little difference outside of the African American community. The study shows how this group of racially mixed individuals who were formerly accustomed to experiences of relative privilege, respond to an unfamiliar racial system that relocates 
them in a lower social stratum - in fact, what is generally perceived as the bottom rung of the American social hierarchy.

Given their memories of a virtually post-racial society and their privileged experience in on the island, my study shows that mixed-race Jamaicans feel great consternation upon arriving in the U.S. and encountering an unfamiliar racial system in which race, especially, the one-drop rule, still draws bright boundaries. Through their racial experiences in the U.S., study participants discover the ways in which borders are patrolled in the U.S. in order to preserve rigid distinctions among various groups. They are shocked by their encounters with several types of boundary-work (through racialization, and racism, through the discovery of racial stereotypes and assumptions of both non-blacks and African Americans about people with black ancestry, through outright racist encounters including racist confrontations and even violence). They are both puzzled and dismayed as they learn about the centrality that race holds in the U.S. And they are particularly critical of the over-emphasis that they feel that African Americans place on race. These findings confirm those of previous scholarship which have shown that West Indians with black ancestry are both shocked and frustrated by racist and racializing encounters (Foner 2001,Vickerman 2001, Waters 1999).

The dissertation shows that what is most startling for my participants is their discovery of the rigid racial categories that, in the U.S., are much more vigorously and carefully patrolled than they are in Jamaica. Participants feel great discomfort when racial boundaries not of their choosing have been drawn around them. They are both puzzled by and resentful of the boundary-work that occurs through the collection of racial data on forms. 
Participants' puzzlement at and discomfort with racial categorization in the U.S. can be explained in various ways. First, the requirement to provide racial information in formal situations - most notably in government forms--does not exist in their country of origin. Second, the requirement forces them to think about race - something that many participants claim they had never done before. Third, and most importantly, the requirement to choose from a limited list of options, the one racial category to which they "belong" is particularly discomfiting for these Jamaicans whose more fluid experience on the island had permitted them more options as far as racial identification. Thus it is not only the requirement to complete forms requesting information on race (and in so doing to 'define' their race in ways that place them in one racial category or another) that is unsettling for my participants. Also disturbing is the realization that based on the onedrop rule, they are being forced into the 'black' category and thereby, ipso facto, association with an underclass.

Given their memories of Jamaica, it is no surprise that interviewees struggle to navigate the racial categories they encounter in the U.S. Accustomed to relative flexibility in racial identifications, certainly unaccustomed to a racial system that enforces black racial identification on persons with black ancestry, respondents seek identifications that most closely reflect their self-conceptualizations. Study survey findings indicate that if given the choice, most participants avoid racial labels entirely in favor of ethnic, that is, "Jamaican" identification. Over 70 percent of the sample consistently made this choice on related questions. And this choice of ethnic rather than racial label suggests that participants are refraining from racial boundary-work. 
However, analysis of interview data made it clear that preferring an ethnic identification does not necessarily preclude the use of a racial label. Most participants are, in fact, carving out racial identifications for themselves. Moreover, most are not identifying as "black." Rather they are "choosing" racial identifications as mixed, multiracial and/or selecting the "other" racial category on forms. That is, most are rejecting the one-drop rule.

Through participants' voices, the dissertation draws attention to the ways in which agency interacts with structure in the formation of racial identifications. Participants indicate that many feel constrained by external forces (such as officially recognized racial categories, socially constructed meanings attached to their phenotypes, and the one-drop rule). At the same time, their stories show how mixed-race Jamaicans exert a tremendous amount of agency in constructing their racial identifications in the U.S. as well - at times in defiance of structural forces. It became clear, through analysis of the data, that individual agency occurs within the constraints of external forces. That is, while some of my participants reject the one-drop rule regardless of how they are characterized by others in this context, their defiance does not change the way they are seen.

Most importantly, the study shows that as mixed-race Jamaicans carve out racial and ethnic identifications they are really participating in the very boundary-work about which they are so critical - though they are usually unaware of this. That they engage in boundary-work is evident too in the efforts they make to distinguish themselves from African Americans; it is also evident in their internal boundary-work by which they make distinctions among themselves. Although only one participant acknowledged doing so, 
this boundary-work is also evident in the overwhelming tendency to limit their social interaction to West Indians - often to the exclusion of African Americans.

The findings of this study thus confirm existing scholarship which has shown that West Indians, much as many non-European immigrants, are uncomfortable with existing racial categories. They search for ways to navigate this unfamiliar racial system (Hintzen 2004, Lee and Bean 2007, Rogers 1999, Vickerman 2001, Waters 1999). My research also confirms the findings of studies that show how black West Indians, among them Jamaicans, actively seek to disassociate themselves from African Americans- a key type of boundary-work. Additionally, in pointing to phenotype and socio-cultural interaction as the most salient factors affecting racial identifications for my participants, the study also confirms findings by other scholars (Clinton 2006, Rockquemore and Brunsma 2002, 2008, Roth 2005). Moreover, they provide additional support for the argument that since all humans are naturally inclined to categorize, everyone engages in boundary-work (Hirschfeld 2005, Massey 2007).

\section{The Study's Contributions}

Since the passage of the 1965 Immigration Act, the demographic composition of the United States has shifted dramatically. The admission of increasing numbers of immigrants from Asia, Africa, Latin America and the Caribbean, representing multiple racial and ethnic groups, and with their own notions about race and racial identification, have continued to challenge the U.S. racial dichotomy. These changing demographics raise questions about the possibility of a future in the U.S. in which the society will be 
post-racial or race may be constructed differently—much as is currently the case in Jamaica. The dissertation sheds light on this possibility in several ways.

First, the study provides examples of what happens when different racial worldviews come into contact. In this case, the U.S. worldview in which racial liminality is not permitted confronts the Jamaican worldview that is accustomed to such. Mixedrace Jamaicans respond to the new racial system by conducting their own boundarywork. Thus, the outcome of the clash of racial worldviews is boundary-work of various types: mixed-race Jamaicans are bounded by people in the U.S. who categorize them as black regardless of their national origins, and they, themselves draw boundaries between themselves and others as well as among themselves. The result is that rather than challenging the U.S. racial worldview, and perhaps even contributing to the dismantling of racial boundaries, Jamaicans are actually participating in their reinforcement.

In highlighting the experiences and perspectives of racially mixed Jamaicans this study makes a second contribution by expanding the literature on West Indians in the U.S. Previous studies (Foner 2001, Rogers 2001, Waters 1999, Vickerman 1999) have emphasized the experiences of black West Indians (or West Indians both deemed and self-identifying as black) giving only cursory mention to the racially mixed. Some (most notably, Waters 1999) have acknowledged that the rigid nature of U.S. racial categories is especially difficult for West Indians given the fact that so many, in their home countries, had been able to lay claim to multiple racial ancestries. But none has focused entirely on one such group. The fact is that not all West Indians are black, and although most Jamaicans have some black ancestry, it is not the case that all consider themselves to be black. Moreover as my study shows, based on their phenotypes, some, especially 
those in the South Florida context, where demography is more complex than in most other parts of the U.S. owing to a majority Hispanic population, are not necessarily racialized as black. The fact that most of my participants have taken advantage of the ways in which their phenotypes (especially in the South Florida context) afford them different experiences, by choosing non-black identifications make them a concrete example of a growing population of U.S. residents who are rejecting the one-drop rule.

The study also highlights the ironic and unintended boundary-work that occurs through the filling out of government application forms - a requirement that is becoming more and more problematic for the increasingly varied populations of the U.S. (Landale and Oropesa 2002, Lee and Bean 2007) The dissertation shows that the U.S. census has historically participated in the creation and reinforcement of both racial categories and the notions attached to them (Goldberg 1997, Nobles 2000). That is, they made previously existing notions official and thereby helped to establish social hierarchies based on race. The collection of racial data, since civil rights, to ensure enforcement of civil rights legislation has had the unintentional consequence of reproducing race itself.

My participants adamantly express their objections to these categories, to the collection of racial data, and to being forced to define themselves racially. Nevertheless, even if not pressured by external forces, they select and apply categories to themselves and to others. The fact is, then, that mixed-race Jamaicans participate in racial boundarywork of which they have been so critical. Moreover, in doing internal boundary-work among themselves they not only contribute to the perpetuation of racial categorization but they also reinforce pejorative notions linked to both race and skin color. Doing so only serves to support the existing racial system. 
This dissertation ultimately makes explicit what most people do implicitlyboundary-work around race. In employing this framework, it highlights the fact that it is through boundary-work that the social construction of race and racial identifications occurs - a factor that has not been previously emphasized. It highlights, moreover, that boundary-work of all types is what maintains and strengthens categories. As Douglas Massey and others have argued, boundaries are the essential building blocks to stratification systems. Thus, as long as people continue to engage in racial boundarywork, we can hardly hope to eliminate social hierarchies that are based on race. Racial categorization perpetuates racial boundary-work. We cannot expect to eliminate racial prejudice as long as race categories continue to be used. By showing how we all (and not just elite groups) contribute to their maintenance, the dissertation points to the possibility of a time in which people of all hues may live together with little (but certainly not entirely without) racial prejudice. The first step is to gain consciousness of doing boundary-work, one of the principal findings of this dissertation.

\section{Limitations and Directions for Future Research}

One limitation of this study, as noted in the introduction, is related to the varied nature of the sample, which made thorough analysis of certain factors difficult. Despite great effort to select only participants with black/white ancestry as a means for controlling variation in the data, it was impossible to hold to this criterion in the original study. Consequently, the sample represented different combinations of racial ancestries. Some participants were biracial (black/white, black/Indian, black/Chinese), others were multiracial (for example, black/white/Indian; black/white/Chinese/Indian etc.) and while 
some were first-generation biracial, others were the offspring of multiracial parents. While this type of variation provided rich data, the small sample size made analysis of the impact of these variations difficult. It seems likely, however, that racial identification outcomes will vary by both generation and racial ancestry. Future research among mixed-race Jamaicans should employ larger samples that will foster exploration of the significance of these factors.

An additional limitation of the study is that in not employing participant observation as part of the research methodology, opportunities for observation of situational identifications were not thoroughly explored. The focus group and interviews provided rich data that has revealed much about the experiences, perspectives and racial identifications of racially mixed Jamaican immigrants. As chapter six shows, these experiences and perspectives do, in fact, demonstrate that mixed-race Jamaicans often report multiple or multilayered identifications, that in some cases shift from context to context. These findings are also supported by previous scholarship on West Indians in particular (Hintzen 1999, 2004, Rockquemore and Brunsma 2007, Rogers 1999) who note that identifications are multilayered and contextual. Observation of interviewees beyond the interview context might have revealed dimensions of their identifications that did not emerge during interviews. As I learned by attending the social events of my two participants, doing so might also, assist the researcher with understanding and interpretation of the data. Future investigations into the performance of identifications of racially mixed West Indians would benefit from such observations.

Although not really a limitation, given that this is a study about migrants' experiences, this dissertation's coverage of race in Jamaica was largely based on 
participants' memories of their lives there. As pointed out in chapter four, to adequately describe race in contemporary Jamaica would require systematic data collection among Jamaicans who live on the island. More recent analyses of race there, moreover, have not focused on racially mixed Jamaicans (see for example, Austin-Broos 1994, 1997, Charles 2003, 2009, Thomas 2002, 2004 2006, Ulysse 1999). My study participants' stories piqued my interest in exploring the experiences of racially mixed Jamaicans currently on the island and in what their "place" there indicate about the role of color and race there. In the future I would like to conduct research on the island itself, and further explore the persistent value of color there. 


\section{REFERENCES}

Adeleke, Tunde

2005 Historical Problematic of Afrocentric Consciousness. Western Journal of Black Studies 29(1):547-558.

Alba, Richard

2005 Bright vs. Blurred boundaries: Second-generation assimilation and exclusion in France, Germany, and the United States. Ethnic and Racial Studies 28(1).

Alexander, Jack

1977 The Culture of Race in Middle-Class Kingston, Jamaica. American Ethnologist 4(3):413-435.

Allahar, Anton

2001 "Race" and Class in the Making of Caribbean Political Culture.

Transforming Anthropology 10(2):13-29.

Alleyne, Mervyn C., ed.

2002 The Construction and Representation of Race and Ethnicity in the Caribbean and the World. Kingston: University of the West Indies Press.

Anderson, Margo I.

2001 Counting by Race: The Antebellum Legacy. In The New Race Question: How the Census Counts Multiracial Individuals. Joel Perlmann and Mary C. Waters, eds. New York: Russell Sage Foundation.

Andrew, Merrick A

2002 The Skin Bleaching Phenomenon. Jamaicans.com.

http://www.jamaicans.com/articles/primecomments/0902 bleaching.shtml. Accessed March 2007.

Appelbaum, Anne S. Macpherson and Karin Alejandra Rosemblatt, ed. 2003 Race and Nation in Modern Latin America. Chapel Hill: University of North Carolina Press.

Aptheker, Herbert

1971 Slave Resistance in the United States. In Key Issues in the Afro-American Experience. N.I. Huggins, Martin Kilson and Daniel M. Fox, eds, Vol. 1. New York: Harcourt Brace Jovanovich.

Austin-Broos, Diane J.

1994 Race/Class: Jamaica's Discourse of Heritable Identity. New West Indian Guide 68(3-4):213-33. 
1997 Jamaica Genesis: Religion and the Politics of Moral Orders. Chicago: University of Chicago Press.

Barnes, Natasha

1997 Face of the Nation: Race, Nationalisms, and Identities in Jamaican Beauty Pageants. In Daughters of Caliban. C. Lopez Springfield, ed. Indianapolis: Indiana University Press.

Barth, Fredrik

1969 Ethnic Groups and Boundaries. Boston: Little, Brown and Company.

Bell, Derrick

1993 Remembrances of Racism Past: Getting Beyond the Civil Rights Decline. In Race in America: The Struggle for Equality. Herbert Hill and James E. Jones Jr., eds. Madison: University of Wisconsin Press.

Benson, Janel E. 2006 Exploring the Racial Identities of Black Immigrants in the United States. Sociological Forum 21(2).

Bethuel, Elizabeth Rauh

1997 The Roots of African-American Identity. New York: St. Martin's Press.

Bretell, Caroline B, ed. 2007 Introduction: Race, Ethnicity, and the Construction of Immigrant Identities. In Constructing Borders/Crossing Boundaries: Race, Ethnicity, and Immigration. Lanham, MD: Lexinton Books.

Binger, Joy D., Halley Johnston, Lynne and Celia H. Brackenridge 2006 Using Computer-Assisted Qualitative Data Analysis Software to Develop a Grounded Theory Project. Field Methods 18:245-266.

Blassingame, John W. 1972 The Slave Community: Plantation Life in the Antebellum South New York, London: Oxford University Press.

Bonilla-Silva, Eduardo 2004 Racial Hierarchy: From bi-racial to tri-racial: Towards a new system of racial stratification in the USA. Ethnic and Racial Studies 27(6):931-950.

Bonilla-Silva, Eduardo

1997 Rethinking Racism: Toward a Structural Interpretation. American Sociological Review 62(3):465-480. 
Brathwaite, Edward

1971 The Development of Creole Society in Jamaica. Oxford: Clarendon Press

Brodber, Erna

1989 Socio-cultural Change in Jamaica. In Jamaica in Independence. Rex

Nettleford, ed. Kingston: Heinemann Caribbean.

Broom, Leonard

1954 The Social Differentiation of Jamaica. American Sociological Review

19(2).

Brown, Aggrey

1974 New Perspectives on Color, Class and Politics in Jamaica. Ann Arbor: University Microfilms.

Brubaker, Rogers and Frederick Cooper

2000 Beyond "Identity". Theory and Society 29:1-47.

Brunsma, David L.

2005 Interracial Families and the Racial Identification of Mixed-Race Children: Evidence from the Early Childhood Longitudinal Study. Social Forces 84(2):1131-1157.

Bryan, Patrick

1991 The Jamaican People 1880-1902. London: MacMillian Education Limited.

1998 The White Minority in Jamaica at the end of the Nineteenth Century. In The White Minority in the Caribbean. H.K.W. Johnson, ed. Pp. 116-130. Kingston/New Jersey: Ian Randle Publishers/Markus Wiener Publishers.

Buddington, Steve A.

2002 Acculturation, psychological adjustment (stress, depression, self-esteem) and the academic achievement of Jamaican Immigrant college students. International Social Work 45(2):447-464.

Burnard, Trevor

1996 European Migration to Jamaica, 1655 to 1780. The William and Mary Quarterly 53(4):769-796.

2002 Not a Place for Whites? Demographic Failure and Settlement in Comparative Context: Jamaica, 1655-1780. In Jamaica in Slavery and Freedom. Kingston: University of the West Indies Press.

Caldwell, Cleopatra Howard, Barbara J. Guthrie and James S. Jackson 2006 Identity Development, Discrimination and Psychological Well-Being 
Among African American and Caribbean Black Adolescents. In Gender, Race, Class and Health: Intersectional Approaches. Amy J. Schulz and Lieth Mullings, eds. San Francisco: Jossey-Bass.

Campbell, Mavis Christine

1976 The Dynamics of Change in a Slave Society: A Sociopolitical History of the Free Coloreds of Jamaica 1800-1865. New Jersey: Associated University Presses.

Campbell, Mary E. 2007 Thinking outside the (black) box: Measuring black and multiracial identification on surveys. Social Science Research 36:921-944.

Charles, Christopher, A. D. 2003 Skin Bleaching, Self-Hate, and Black Identity in Jamaica. Journal of Black Studies 33(6):711-728.

2009 Skin Bleachers' Representation of Skin Color in Jamaica. Journal of Black Studies 40(2):153-170.

2010 Representations of Colorism in the Jamaican Culture and the Practice of Skin Bleaching, City University of New York.

Charmaz, Kathy

2001 Grounded Theory. In Contemporary Field Research. R.M. Emerson, ed. Long Grove, Illinois: Waveland Press, Inc.

Chevannes, Barry

1998 Rastafari and the Exorcism of the Ideology of Racism and Classism in Jamaica. In Chanting Down Babylon: The Rastafari Reader. Nathaniel Samuel Murrell, William D. Spencer \& Adrian Anthony McFarlane, eds. Philadelphia: Temple University Press.

Clinton, Yvette C 2006 Clusters of Racial Identity Among Black/White Biracial Students: A Mixed Method Investigation. Ph.D. dissertation, Department of Psychology, University of Michigan.

Cooper, Carolyn

2004 Enslaved in Stereotype: Race and Representation in Post-Independence Jamaica. Small Axe 16:154-169.

Corbin, Juliet and Anselm Strauss 2008 Basics of Qualitative Research: Techniques for Developing Grounded Theory. Los Angeles: Sage Publications. 
Cornell, Stephen and Douglas Hartmann

1998 Ethnicity and Race: Making Identities in a Changing World. Thousand Oaks, London, New Delhi: Pine Forge Press.

Craig, Susan

1981 Sociological Theorizing in the English-Speaking Caribbean. In Comtemporary Caribbean: A Sociological Reader. S. Craig, ed. Maracas: The College Press.

Curtin, Philip

1955 Two Jamaicas: Harvard University Press.

1971 The Slave Trade and the Atlantic Basin: Intercontinental Perspectives. In Key Issues in the Afro-American Experience. Nathan Huggins, Martin Kilson and Daniel M. Fox, eds. New York: Harcourt Brace Jovanovic.

DaCosta, Kimberly McClain 2007 Making Multiracials: State, Family, and Market in the Redrawing of the Color Line. Stanford, California: Stanford University Press.

Dalmage, Heather 2000 Tripping on the Color Line: Black-White Multiracial Families in a Racially Divided World. New Jersey: Rutgers University Press.

Daniel, Reginald C. 1996 Black and White Identity in the New Millennium: Unsevering the Ties that Bind. In The Multiracial Experience: Racial Borders as the New Frontier. Maria P.P. Root, ed. Thousand Oaks: Sage.

Daniel, Reginald G.

2004 Black Essentialism and the Afrocentric Idea: The Demise of Eurocentrism or Eurocentrism in a New Guise? In Racial Thinking in the United States: Uncompleted Independence. Paul Spickard and Reginald G. Daniel, eds. Notre Dame: University of Notre Dame Press.

2004 Black No More or More than Black? Multiracial Identity Politics and the Multiracial Movement. In Racial Thinking in the United States. Paul R. Spickard and Reginald G. Daniel, eds. Notre Dame: University of Notre Dame.

Davidson, Basil

1971 Slaves or Captives? Some Notes on Fantasy and Fact. In Key Issues in the Afro-American Experience. Nathan Huggins, Martin Kilson and Daniel M. Fox, eds. New York: Harcourt Brace Jovanovich, Inc. 


\section{Davis, F. James}

1991 Who Is Black? One Nation's Definition. University Park: Penn State University Press.

1995 The Hawaiian Alternative to the One-Drop Rule. In American Mixed Race: The Culture of MicroDiversity

Denton, Nancy and Stewart Tolnay, eds.

2002 The Social Construction of Race and Ethnicity: Some Examples from Demography. Albany: State University of New York Press.

Dominguez, Virginia

1993 White By Definition: Social Classification in Creole Louisiana. New Brunswick: Rutgers.

Douglas, Mary

2002 [1966] Purity and Danger.

D'Souza, Dinesh

1995 The End of Racism. New York: The Free Press.

Dunn, L. C.

1975 Race and Biology. In Race, Science and Society. Leo Kuper, ed. Pp. 3167. New York: Columbia University Press.

Dunn, Marvin

1997 Black Miami in the Twentieth Century. Gainesville: University Press of Florida

Dunn, Richard C.

1972 Sugar and Slaves: The Rise of the Planter Class in the English West Indies, 1624-1713. Kingston: University of the West Indies Press.

Elkins, Stanley

1971 The Social Consequences of Slavery. In Key Issues in the Afro-American Experience. Nathan Huggins, Martin Kilson and Daniel M. Fox, eds. New York: Harcourt Brace Jovanovich, Inc.

Feagin, Joe R.

1991 The Continuing Significance of Race: Antiblack Discrimination in Public Places. American Sociological Review 56(1):101-116. 
Ferber, Abby L.

1995 Exploring the Social Construction of Race: Sociology and the Study of Interracial Relationships. In American Mixed Race. Naomi Zack, ed. Pp. 155-167. Lanham, Maryland: Rowman \& Littlefield.

Ferber, Abby L

1999 The Construction of Race, Gender, and Class in White Supermacist Discourse. Race, Gender and Class 6(3).

Fernandez, Carlos A 2001 Government Classification of Multiracial/Multiethnic People. In The Multiracial Experience: Racial Borders as the New Frontier. Maria P. P. Root, ed. California: Sage Publications.

Field, Tamara Kerrill 2009 Being Biracial in a Mixed-up World. In Chicago Tribune, November 29.

Foner, Nancy, ed.

2001 Islands in the City: West Indian Migration to New York. Los Angeles: University of California Press.

Foote, Nicola

2006 Race, State, and Nation in Early Twentieth Century Ecuador. Nations and Nationalism 12(2):261-278.

Ford-Smith, Honor

1995

Making White Ladies: Race, Gender and the Production of Identities in Late Colonial Jamaica. Resources for Feminist Research 23(4):55.

Franklin, John Hope

1967 From slavery to freedom: A History of Negro Americans. New York: Alfred A. Knopf.

2005 The Two Worlds of Race: a Historical View. Daedalus 134(4):118(16).

Frazier, E. Franklin

1966 The Negro Family in the United States. Chicago: University of Chicago Press.

Fredrickson, George

1971 Toward a Social Interpretation of the Development of American Racism. In Key Issues in the Afro-American Experience. Nathan Huggins, Martin Kilson and Daniel M. Fox, ed. New York: Harcourt Brace Jovanovic. 
Garvey, Marcus

1916 [1973] The Race Question in Jamaica. In Consequences of Class and Color: West Indian Perspectives. David Lowenthal and Lambros Comitas, eds. New York: Anchor Books.

Gieryn, Thomas F.

1983 Boundary-Work and the Demarcation of Science from Non-Science:

Strains and Interests in Professional Ideologies of Scientists. American

Sociological Review 48(6):781-795.

Gilroy, Paul

2000 Against Race. Cambridge: Harvard University Press.

2004 After Empire: Melancholia or Convival Culture? Abingdon: Routledge.

Glick Schiller, Nina and Georges Eugene Fouron

2001 Georges Woke Up Laughing: Long-Distance Nationalism and the Search for Home. Durham: Duke University Press.

Goldberg, David Theo

1997 Racial Subjects: Writing on Race in America. New York: Routledge.

Gordon, Derek

1991 Race, Class and Social Mobility in Jamaica. In Garvey: His Work and His Impact. Rupert Lewis and Patrick Bryan, eds. Trenton: Africa World Press.

Gossett, Thomas F.

1963 Race: The History of an Idea in America. New York: Oxford University Press.

Gould, Stephen J

1981 The Mismeasure of Man: W. W. Morton and Company.

Gregory, Steven and Roger Sanjek, eds.

1994 Race. New Brunswick: Rutgers University Press.

Grillo, Trina

2003 Anti-Essentialism and Intersectionality: Tools to Dismantle the Master's House. In Mixed Race America and the Law. K.R. Johnson, ed. New York: New York University. 


\section{Hackshaw, Alana}

2006 Black Ethnicity and Racial Community: African-Americans and West Indian Immigrants in the United States. In Constructing Borders/Crossing Boundaries: Race, Ethnicity and Immigration. Caroline Bretell, ed. New York: Rowman \& Littlefield.

Hadley, C.V. D.

1973 Personality Patterns, Social Class and Aggression in the British West Indies. In Consequences of Class and Color: West Indian Perspectives. David Lowenthal and Lambros Comitas, eds. New York: Anchor Books.

Haney Lopez, Ian F.

1996 White by Law: The Legal Construction of Race. New York: New York University Press.

2003 The Social Construction of Race: Some observations on Illusion, Fabrication and Choice. In Mixed Race America and the Law. K.R. Johnson, ed. New York: New York University Press.

Harris, David and Jeremiah Joseph Sim 2002 Who is Multiracial? Assessing the Complexity of Lived Race. American Sociological Review (67):614-627.

Harris, Marvin

1964 Patterns of Race in the Americas. New York: W. W. Norton.

Headley, Bernard D.

1984 Toward a Cyclical Theory of Race Relations in Jamaica. Journal of Black Studies 15(2):207-222.

Henriques, Fernando

1964 Jamaica: Land of Wood and Water. New York: London House \& Maxwell

1968 Family and Colour in Jamaica. London: MacGibbon and Kee.

Heuman, Gad Joseph

1976 Between Black and White: Brown Men In Jamaican Politics and Society, 1823 - 1865. Ann Arbor: University Microfilms International.

Hintzen, Percy

1999 Identity, Arena, and Performance: Being West Indian in the San Francisco Bay Area. In Representations of Blackness and the Performance of Identities. Jean Muteba Rahier, ed. Westport: Bergin \& Garvey. 
2001 West Indians in the West. New York New York University Press.

2003 Whiteness, Desire, Sexuality, and the Production of Black Subjectivities in British Guiana, Barbados and the United States. In Problematizing Blackness:

Self-Ethnographies by Black Immigrants to the United States. Percy Hintzen and Jean Muteba Rahier eds. New York: Rutledge.

2004 Imagining Home: Race and the West Indian Diaspora in the San Francisco Bay Area. Journal of Latin American Anthropology 9(2):289-318.

Hintzen, Percy and Jean Muteba Rahier eds.

2003 Problematizing Blackness: Self-ethnographies by Black immigrants to the US. New York: Routledge.

Hirschfeld, Lawrence A.

2005 Children's Understanding of Racial Groups. In Children's Understanding of Society. M.a.E.B.-B. Barrett, ed. Hove(England): Psychology Press.

Hoetink, $\mathrm{H}$.

1971 Caribbean Race Relations: A study of two variants. London: Oxford University Press.

1985 "Race" and Color in the Caribbean. In Caribbean Contours. Sidney Mintz and Sally Price, eds. Baltimore: John Hopkins University Press.

Holt, Thomas C.

2004 Understanding the Problematic of Race through the Problem of Race-

Mixture. Race and Human Variation: Setting an Agenda for Future Research and Education, Alexandria, Virginia, 2004. American Anthropological Association.

Huggins, Nathan I., Martin Kilson \& Daniel M. Fox, eds.

1971 Key Issues in the Afro-American Experience. Volume 1 and 2. New York: Harcourt Brace Jovanovich Inc.

Hutton, Clinton C and Nathaniel Samuel Murrell

1998 Rastas' Psychology of Blackness In The Rastafari Reader: Chanting down Babylon Nathaniel Samuel Murrell, William David Spencer and Adrian Anthony McFarlane, eds. Pp. 326-348. Philadelphia: Temple University Press.

Isbister, John

1996 The Immigration Debate: Remaking America. West Hartford: Kumarian Press. 
Jaynes, Gerald

2004 Immigration and the Social Construction of Otherness: "Underclass"

Stigma and Intergroup Relations. In Not Just Black and White. Nancy Foner and George M. Fredrickson, eds. New York: Russell Sage Foundation.

Jenkins, Richard

2004 Social Identity. London/New York: Routledge.

Johnson, Kevin R, ed.

2003 Mixed Race America and the Law. New York: New York University

Press.

Johnson, Violet M. Showers

2008 "What, Then, Is the African American?" African and Afro-Caribbean Identities in Black America. Journal of American Ethnic History 28(1).

Johnson, Violet Showers

2005 Racial Frontiers in Jamaica's Nonracial Nationhood. In Race and Nation: Ethnic Systems in the Modern World. Paul R. Spickard, ed. New York:

Routledge.

Jones, Terry-Ann

2007 Jamaican Immigrants in the United States and Canada: Race,

Transnationalism, and Social Capital. 2007: LFB Scholarly Publications LLC.

Kasinitz, Philip, Juan Battle and Ines Miyares

2001 Fade to Black? The Children of West Indian Immigrants in South Florida.

In Ethnicities: Children of Immigrants in America. Berkeley: University of

California Press.

Kaufman, Michael

1985 Jamaica Under Manley. London: Zed Books.

Kuper, Adam

1976 Changing Jamaica. Kingston: Kingston Publishers.

Lamont, Michele, and Virag Molnar 2002 The Study of Boundaries in the Social Sciences. Annual Review of Sociology 28:167-195.

Landale, Nancy S. and R. S. Oropesa

2002 White, Black, or Puerto Rican? Racial Self-Identification among Mainland and Island Puerto Ricans. Social Forces 81(1):231-254. 
Lawrence, Cecile Ann

1995 Racelessness. In American Mixed Race. N. Zack, ed. Pp. 25-37. Lanham, Maryland: Rowman \& Littlefield.

Lee, Jennifer and Frank Bean

2007 Reinventing the Color Line: Immigration and America's New

Racial/Ethnic Divide. Social Forces 86(2).

Lee, Sharon M and Barry Edmonston

2005 New Marriages, New Families: U.S. Racial and Hispanic Intermarriage. Population Bulletin 60(2).

Lee, Sharon M

1993 Racial Classifications in the US Census: 1890-1990. Ethnic and Racial Studies 16(1).

Lewis, Gordon K.

1985 The Contemporary Caribbean. In Caribbean Contours. Sidney Mintz and Sally Price, eds. Baltimore: Johns Hopkins University Press

Lowenthal, David

1971 Post-Emancipation Race Relations: Some Caribbean and American Perspectives. Journal of Interamerican Studies and World Affairs 13(3/4):367377.

Lowenthal, David and Lambros Comitas, eds.

1973 Consequences of Class and Color: West Indian Perspectives. New York: Anchor Books.

Massey, Douglas

2007 Categorically Unequal: The American Stratification System. New York: Russell Sage Foundation.

McFeely, William S.

1971 The Freedman's Bureau and Federal Action in Race Relations. In Key Issues in the Afro-American Experience. Nathan Huggins, Martin Kilson and Daniel M. Fox, eds, Vol. 2. New York: Harcourt Brace Jovanovich Inc.

Meier, August

1969 Negro Thought in America. Ann Arbor: University of Michigan Press. 
Miller, Errol

2001 Body Image, Physical Beauty and Colour Among Jamaican Adolescents. In Caribbean Sociology: Introductory Readings. C.R.R. Barrow, ed. Oxford: James Currey Publishers.

Mohammed, Patricia

2000 'But most of all mi love mi browning': The Emergence in Eighteenth and Nineteenth Century Jamaica of the Mulatto Woman as the Desired. Feminist Review 65:22-48.

Munroe, Trevor

1991 The Left and the Question of Race in Jamaica. In Garvey, His Work and Impact. Rupert Lewis and Patrick Bryan, eds. Trenton: Africa World Press.

Murrell, Nathaniel Samuel

1998 The Rastafari Phenomenon. In Chanting Down Babylon. Nathaniel S. Murrell, William David Spencer and Adrian Anthony McFarlane, ed.

Philadelphia: Temple University Press.

Myrdal, Gunnar

1944 An American Dilemma: The Negro Problem and Modern Democracy. Volumes 1 and 2. New York: Harper and Row.

Nagel, Joane

2003 Race, Ethnicity and Sexuality. New York: Oxford University Press.

Nettleford, Rex

1973 National Identity and Attitudes to Race in Jamaica. In Consequences of Class and Color: West Indian Perspectives. David Lowenthal and Lambros Comitas, eds. New York: Double Day.

1998 [1970] Mirror Mirror: Identity, Race and Protest in Jamaica. London: LMH Publishing.

Nobles, Melissa

2000 The Tables Present Plain Matters of Fact: Race Categories in U.S. Censuses. In Shades of Citizenship: Race and the Census in Modern Politics. Stanford: Stanford University Press.

2002 Racial Categorization and Censuses. In Census and Identity: The Politics of Race, Ethnicity, and Language in National Censuses. David Kertzer and Dominique Arel, eds. Pp. 43-70. Cambridge: Cambridge University Press. 
Norrell, Robert J.

2005 The House I Live In. New York: Oxford University Press.

Omi, Michael \& Howard Winant

1994 Racial Formation in the United States. New York: Routledge.

Patterson, Orlando

1975 Context and Choice in Ethnic Allegiance: A Theoretical Framework and Caribbean Case Study. In Ethnicity: Theory and Experience. Nathan Glazer and Daniel P. Moynihan, eds. Cambridge: Harvard University Press.

Pease, William H. and Jane H. Pease

1971 The Negro Convention Movement. In Key Issues in the Afro-American Experience. N.I. Huggins, Martin Kilson and Daniel M. Fox, eds. New York: Harcourt Brace Jovanovich.

Perlmann, Joel and Mary C. Waters, eds.

2002 The New Race Question: How the Census Counts Multiracial Individuals. New York: Russell Sage Foundation.

Portes, Alejandro and Alex Stepick

1993 City on the Edge: The Transformation of Miami. Berkeley: University of California Press.

Quarles, Benjamin

1971 Freedom's Black Vanguard. In Key Issues in the Afro-American

Experience. N.I. Huggins, Martin Kilson and Daniel M. Fox, eds. Vol. 1. New

York: Harcourt Brace Jovanovic.

Rahier, Jean Muteba

2003 Metis/Mulatre, Mlato, Mulatto, Negro, Moreno, Mundele, Kaki, Black, . . .The Wanderings and Meanderings of Identities. In Problematizing Blackness:

Self-Ethnographies by Black Immigrants to the United States. Percy Hintzen and Jean Muteba Rahier, eds. New York: Routledge.

Reuter, Edward Byron

1969 The Mulatto in the United States. New York: Negro Universities Press.

Richards, Glen

2002 Race, Class and Labour Politics in Colonial Jamaica, 1900-1934. In Jamaica in Slavery and Freedom: History, Heritage and Culture. Kathleen Monteith and Glen Richards, eds. Kingston: University of the West Indies Press.

Rockquemore, Kerry

1999 Race and Identity: Exploring the Biracial Experience, University of Notre Dame. 
Rockquemore, Kerry Ann and David L. Brunsma

2002 Socially Embedded Identities: Theories, Typologies, and Processes of Racial Identity among Black/White Biracials. The Sociological Quarterly 43(3):335-356.

2008 Beyond Black: Biracial Identity in America. New York: Rowman and Littlefield.

Rogers, Reuel

1999 Black Like Who? Afro-Caribbean Immigrants, African Americans, and the Politics of Group Identity. In Islands in the City: West Indian Migration to New York. Nancy Foner, ed. Berkeley: University of California Press.

Root, Maria P

2001 Love's Revolution: Interracial Marriage. Philadelphia: Temple University Press.

Root, Maria P. P. 1996 A Bill of Rights for Racially Mixed People. In The Multiracial Experience: Racial Borders as the New Frontier. M.P.P. Root, ed. Thousand Oaks: Sage Publications.

1997 Mixed-Race Women. In Race/Sex: Their Sameness, Difference, and Interplay. N. Zack, ed. New York: Routledge.

Roth, Wendy

2005 The End of the One-Drop Rule? Labeling Multiracial Children in Black Intermarriages. Sociological Forum 20(1):35-67.

Sanjek, Roger

1994 The Enduring Inequalities of Race. In Race. Steven Gregory and Roger Sanjek, eds. New Brunswick: Rutgers University Press.

1994 Intermarriage and the Future of Races in the United States. In Race. Steven Gregory and Roger Sanjek, eds. New Brunswick: Rutgers University Press.

Segal, Ronald

1995 The Black Diaspora. New York: Farrar, Straus and Giroux.

Sherlock, Phillip and Hazel Bennett

1998 The Story of the Jamaican People. Kingston: Ian Randle Publishers. 
Sibley, David

1995 Geographies of Exclusion. London: Routledge.

Smedley, Audrey

2007 Race in North America: Origin and Evolution of a Worldview. Boulder:

Westview Press.

Smith, M. G.

1974 The Plural Society in the British West Indies. Los Angeles: University of California Press.

1984 Culture, Race and Class in the Commonwealth Caribbean. Kingston: University of the West Indies.

Sollors, Werner

1997 Neither black nor white yet both. Cambridge: Harvard University Press.

2001 What Race Are You? In The New Race Question. Joel Perlmann and Mary Waters, eds. New York: Russell Sage Foundation.

Spencer, Jon Michael

1997 The New Colored People. New York: New York University Press.

Spickard, Paul R

1989 Mixed Blood: Intermarriage and Ethnic Identity in Twentieth Century America. Madison: University of Wisconsin Press.

Spickard Paul, R ed.

2005 Race and Nation: Ethnic Systems in the Modern World. New York:

Routledge.

Stampp, Kenneth M.

1971 The Daily Life of Southern Slaves. In Key Issues in the Afro-American Experience. N.I. Huggins, Martin Kilson and Daniel M. Fox, eds, Vol. Vol. 1. New York: Harcourt Brace Jovanovich, Inc.

Stepick, Alex, Carol Dutton Stepick, Emmanuel Eugene, Deborah Teed and Yves Labissiere

2001 Shifting Identities and Intergenerational Conflict: Growing Up Haitian in Miami. In Ethnicities: Children of Immigrants in America. Ruben G. Rumbaut and Alejandro Portes, eds. New York: Russell Sage Foundation.

Stone, Carl

1973 Class, Race and Political Behaviour in Urban Jamaica. Kingston:

University of the West Indies. 
1991 Race and Economic Power in Jamaica. In Garvey: His Work and His Impact. Rupert Lewis and Patrick Bryan, eds. Trenton: Africa World Press.

Taylor, Orville W.

2006 Black and Unapologetic. In Jamaica Gleaner. August 30.

Thomas, Deborah

2002 Democratizing Dance: Institutional Transformation and Hegemonic Re-

Ordering in Postcolonial Jamaica. Cultural Anthropology 17(4):512-550.

2004 Modern Blackness. Durham: Duke University Press.

2006a Modern Blackness: Progress, "America," and the Politics of Popular Culture in Jamaica. In Globalization and Race: Transformations in the Cultural Production of Blackness. Kamari Maxine Clarke and Deborah Thomas, eds. Durham: Duke University Press.

2006b Public Bodies: Virginity Testing, Redemption Songs, and Racial Respect in Jamaica. Journal of Latin American Anthropology, 11(1):1-31.

Thornton, Michael C.

2004 Race and Multiraciality: Multiracial Challenges to Monoracialism. In Racial Thinking in the United States. Paul R. Spickard and G. Reginald Daniel, eds. Notre Dame: University of Notre Dame Press.

Tormala, Teceta Thomas and Kay Deaux 2006 Black Immigrants to the United States: Confronting and Constructing Ethnicity and Race. In Cultural Psychology of Immigrants. R. Mahalingam, ed. Pp. 131-150. Mahwah, New Jersey/London: Lawrence Erlbaum Associates.

Tsuji, Teruyuki

2008 Villaging the Nation: The Politics of Making Ourselves in Postcolonial Trinidad. Callaloo 31(4):1148-1174.

Twine, Frances Widdance, ed. 1996 Heteosexual Alliances: The Romantic Management of Racial Identity. London: Sage Publications.

Ulysse, Gina

1999 Uptown Ladies and Downtown Women: Female Representations of Class and Color in Jamaica. In Representations of Blackness and the Performance of Identities. Jean Muteba Rahier, ed. Pp. 147-172. Westport, Connecticut: Bergin and Garvey. 
Vickerman, Milton

1999 Crosscurrents: West Indian Immigrants and Race. New York: Oxford University Press.

2001 Tweaking a Monolith: The West Indian Immigrant Encounter with "Blackness". In Islands in the City: West Indian Migration to New York. N. Foner, ed. Berkeley: University of California Press.

Visweswaran, Kamala

1998 Race and the Culture of Anthropology. American Anthropologist 100(1):70-83.

Washington, Durthy

1994 On Being Biracial. Interrace 5(6).

Waters, Mary C.

1994 Ethnic and Racial Identities of Second-Generation Black Immigrants in New York City. International Migration Review 28(4):795-820.

1999 Black Identities: West Indian Immigrant Dreams and American Realities. New York: Russell Sage Foundation.

1999 Explaining the Comfort Factor: West Indian Immigrants Confront American Race Relations. In The Cultural Territories of Race: Black and White Boundaries. M. Lamont, ed.

2001 Growing up West Indian and African American: Gender and Class Differences in the Second Generation. In Islands in the City: West Indian Migration to New York. Nancy Foner, ed. Berkeley: University of California Press.

West, Cornel

1993 Race Matters.

Williams Jr., Vernon

2001 Racial Essentialism: a Case of Historical Continuity and Discontinuity in the Social Sciences. Western Journal of Black Studies 25(4):202-211.

Williams, Kim M. 2005 Multiculturalism and the Civil Rights Future. Daedalus 134(1):530-538.

2006 Mark One or More: Civil Rights in Multiracial America. Ann Arbor: University of Michigan Press.

Williams, Teresa Kay 
1996 Race as Process: Reassessing the "What are You?" Encounters of Biracial Individuals. In The Multiracial Experience. Maria P.P. Root, ed. Thousand Oaks: SAGE Publications.

Williamson, Joel

1971 Black Self-Assertion Before and After Emancipation. In Key Issues in the Afro-American Experience. N.I. Huggins, Martin Kilson and Daniel M. Fox, eds. New York: Harcourt Brace Jovanovich.

1995 New People: Miscegenation and Mulattoes in the United States. Baton Rouge: Louisiana State University Press.

Wilson, William Julius

1980 The Declining Significance of Race: Blacks and Changing American Institutions. Chicago: University of Chicago Press.

Wyckoff, Theodore

1972 Race, Color and Prejudice: Solutions from Three Countries. Journal of Negro Education 41(3):195-201.

Zack, Naomi

1993 Race and Mixed Race. Philadelphia: Temple University Press.

Zack, Naomi ed.

1995 American Mixed Race. Lanham: Rowman and Littlefield.

1997 The American Sexualization of Race. In Race/Sex: Their Sameness, Difference, and Interplay. N. Zack, ed. New York: Routledge.

Zarembka, Joy M.

2007 The Pigment of Your Imagination. Washington: Madera Press. 


\section{APPENDICES}

APPENDIX 1 - Research Participants

\begin{tabular}{|c|c|c|c|c|c|}
\hline NAME & AGE & YRS IN US & GEN MIXED RACE & RACIAL ANCESTRIES & COUNTY RESIDENCE \\
\hline Albert & 28 & 10 & FIRST & BLACK/INDIAN & BROWARD \\
\hline Althea & 43 & 4 & SECOND & BLACK/WHITE & BROWARD \\
\hline Andrew & 27 & 2 & SECOND OR MORE & BLACK/WHITE/CHINESE/INDIAN & PALM BEACH \\
\hline Anita & 34 & 15 & FIRST & BLACK/INDIAN & PALM BEACH \\
\hline Audrey & 38 & 23 & SECOND & BLACK/WHITE & MIAMI DADE \\
\hline Brian & 37 & 6 & FIRST & BLACK/WHITE & BROWARD \\
\hline Caroline & 40 & 19 & SECOND & BLACK/WHITE/INDIAN & BROWARD \\
\hline Cecile & 34 & 19 & SECOND & BLACK/WHITE/INDIAN & PALM BEACH \\
\hline Christine & 48 & 29 & SECOND OR MORE & BLACK/WHITE/INDIAN & BROWARD \\
\hline Colin & 32 & 6 & SECOND & BLACK/WHITE & PALM BEACH \\
\hline Cynthia & 22 & 6 & SECOND OR MORE & BLACK/WHITE/CHINESE/INDIAN & BROWARD \\
\hline Damian & 38 & 9 & FIRST & BLACK/CHINESE/(WHITE) & BROWARD \\
\hline Deborah & 38 & 23 & FIRST & BLACK/WHITE & BROWARD \\
\hline Denise & 24 & 5 & SECOND OR MORE & BLACK/CHINESE/INDIAN & MIAMI DADE \\
\hline Garry & 29 & 9 & FIRST & BLACK/WHITE/INDIAN & BROWARD \\
\hline Glenn & 44 & 29 & SECOND OR MORE & BLACK/CHINESE/INDIAN(WHITE) & PALM BEACH \\
\hline Jennifer & 28 & 8 & SECOND OR MORE & BLACK/WHITE/INDIAN & BROWARD \\
\hline Justin & 26 & 7 & FIRST & BLACK/CHINESE/WHITE & MIAMI DADE \\
\hline Karen & 26 & 9 & FIRST & BLACK/INDIAN & BROWARD \\
\hline Karlene & 26 & 4 & SECOND OR MORE & BLACK/WHITE/INDIAN & BROWARD \\
\hline Kevin & 26 & 9 & SECOND OR MORE & BLACK/WHITE/INDIAN & BROWARD \\
\hline Leighton & 41 & 23 & FIRST & BLACK/WHITE & VERO BEACH \\
\hline Michael & 26 & 6 & SECOND OR MORE & BLACK/WHITE/CHINESE/INDIAN & BROWARD \\
\hline Nicola & 24 & 6 & SECOND OR MORE & BLACK/WHITE/INDIAN & PALM BEACH \\
\hline Norman & 46 & 21 & SECOND OR MORE & BLACK/WHITE & PALM BEACH \\
\hline Patrice & 42 & 0 & SECOND OR MORE & BLACK/WHITE/INDIAN & BROWARD \\
\hline Patrick & 37 & 18 & SECOND OR MORE & BLACK/WHITE/ & BROWARD \\
\hline Paul & 26 & 15 & SECOND OR MORE & BLACK/WHITE/INDIAN & BROWARD \\
\hline Peter & 25 & 17 & FIRST & BLACK/WHITE & BROWARD \\
\hline Sandra & 45 & 29 & SECOND & BLACK/WHITE & MIAMI DADE \\
\hline Sean & 46 & 24 & SECOND & BLACK/WHITE/CHINESE/INDIAN & BROWARD \\
\hline Susan & 25 & 7 & SECOND OR MORE & BLACK/WHITE/CHINESE & MIAMI DADE \\
\hline Tracy & 27 & 9 & SECOND OR MORE & BLACK/WHITE/CHINESE/INDIAN & PALM BEACH \\
\hline Vivica & 32 & 15 & SECOND OR MORE & BLACK/WHITE/CHINESE/INDIAN & BROWARD \\
\hline
\end{tabular}


APPENDIX 2 - Interview Protocol

\section{INTRODUCTION:}

Thank you very much for taking the time to do this interview. As you may recall from your letter of invitation and from the survey you recently completed I am a $\mathrm{Ph}$.D. student and my research topic is exploring racial identity among racially mixed Jamaicans in South Florida. Before we begin I wanted to remind you that while there are no risks I can think of to your participating in this study, as I have promised, your participation is entirely confidential. If you have any questions at all as we proceed, please feel free to stop me so I may provide any clarification you may need. Please also remember that you may contact me at any time after our interview at placides@fiu.edu. May I continue?

\section{SECTION I: BACKGROUND: Racial Experiences in Jamaica}

1. As you know I am interested in learning about your experiences as a mixed-race person in the United States. I'd like to begin by learning a bit about how you think about race in general.

a. Would you say that you think about race at all?

b. If so, what does race mean to you?

c. Would you say that you think about race frequently?

d. Can you give me one example of a recent circumstance/situation that prompted you to think about race?

2. Now think back to when you lived in Jamaica. For now try to forget your experiences here in the U.S. Pretend that I am from another country and I have no knowledge of how people think about race in Jamaica. Explain to me as much as you can about race, racial identity and racial groups in Jamaica as you know them.
a. Checklist: covered race racial identity racial groups

b. Explain as much as you can where your ideas come from and how you got them.

c. What experience(s) have you had that might have had a profound effect on the way you view race?

d. Can you tell me a story from your own experience or someone you know that would help me understand race in Jamaica?

3. I'd like to learn the racial history of your family going back to your greatgrandparents. Please tell me about that history? How would you describe these family members racially? (Give as many races as you know for each person.)

a. Checklist - Races of :

i. mother

ii. father

iii. maternal grandmother 


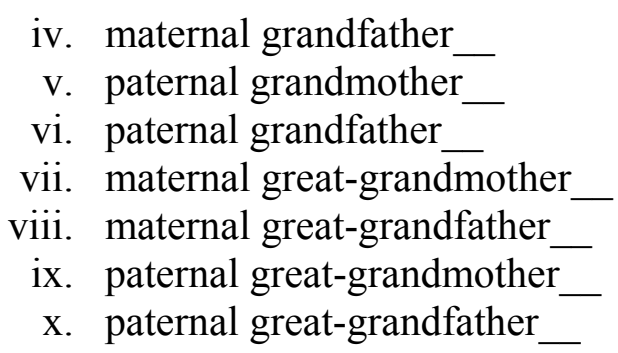

b. I asked for your description of the above family members. Do you know how they thought of themselves racially? How would each describe himself/herself?

4. Now I know that since race and identity are complex, there might be differences between how you and your ancestors and family view their racial identities. How did your immediate family members view themselves racially and why?

i. Where do/did they get their ideas about race?

ii. Did/do they talk openly about race, racial identity or color?

iii. What features (skin color, nose, lips, hair) were important to them and what did they signify?

iv. Can you name some terms that family members may use about others that are about race or color?

v. Did these terms reflect anything you saw or heard in the media (TV/radio/popular music)? If so, please explain.

a) For example, are there any TV characters that people use or have used in the past to talk about race?

5. Remembering that I've asked you to try to temporarily forget your experiences in the U.S. can you tell me how you thought of yourself racially while you lived in Jamaica and why?

Probes:

Checklist using Jamaican census categories: (black_ East Indian Chinese _White _ Mixed _ Other

○ Did you characterize your racial identity based your skin color/hair type/other physical features (nose/lips)/class?

- Think back to your primary/prep school? How would you describe yourself compared to other classmates?

- How about your high/secondary school. How would you describe yourself compared to other classmates?

- How about your neighborhood? How would you describe yourself compared to other children in the neighborhood in which you grew up? (Ask about different neighborhoods if family moved a lot). 


\section{SECTION II: Racial Experiences in the U.S.}

6. Now imagine that you are back on the plane that first brought you to the U.S. when you immigrated. Describe how you would have characterized your racial identity if I had interviewed you then.

Probe:

- Try to picture that first hour or so (perhaps while you were still in airport), how do you compare with people around you? How would characterize yourself in relation to them?

○ The U.S. government collects information on race of immigrants. Do you recall what race you put yourself as (or your parents put you as) on your immigration forms? What was it?

7. Now think about your first days, weeks, months, in the U.S. What did you experience about race here and how was it similar to or different from Jamaica?

Probes:

- Can you think of a story about yourself or someone else, a specific encounter that illustrates what you just shared?

○ How were you affected by that encounter?

8. Now that you have had some time living in the U.S. would you say that people view race similarly or differently from how people view it in Jamaica? Explain.

Probes:

- How does the typical Jamaican view race and how does it differ from or resemble the way(s) in which the typical American views race?

- Which of these perspectives about race would you say is closer to your own current view on race? Why?

- If respondent gives US. Why s/he has shifted.

$\circ$ If respondent gives Jamaica ask why s/he has not shifted.

9. What have you learned about the racial identity of black/white biracial individuals in the U.S.? What specific term(s) have been used in reference to them?

Probe:

○ Can you give specific examples? People you know personally (Give first name and gender)

○ How about famous individuals? Musicians/actors/politicians (Obama)

10. I chose to interview you because you told me before that you have a racially mixed background. Please help me understand what this means to you.

Probes: 
- Do you feel that being racially mixed in the U.S. is similar to or different from being racially mixed in Jamaica?

- If similar, what are the similarities? If different, differences?

- Has anything happened in the U.S. that changed your perception of yourself?

- If so, in what way(s) have your perceptions changed?

- Has your racial identity changed? In what way?

\section{SECTION III: Exposure to U.S. Racial Worldview in Formal and Informal Contexts}

11. Now tell me about your family:

a. Your survey response indicated that you are [insert marital status]. What is/was your spouse's race?

b. How many members of your immediate have also migrated to South Florida?

c. Did they arrive in the U.S. about the same time as you? Before? After?

d. How have they talked about their experiences with racial encounters in the U.S.? If so, can you give examples of what they have said? [Listen for indication that experiences have impacted in family members' racial identity. If does not arise, ask.]

12. Now I'd like to ask you about your friendships. Would you please provide me with their first names only? Which ones are from the U.S. and which are from another country?

a. For each name please describe this person's racial identity.

b. What physical features are important to them? What do these physical features signify?

c. Has [person's name] ever discussed his/her race and/or racial experiences with you? Please describe.

d. [IF FRIEND'S JAMAICAN] Do you think this person feels racially similar to how s/he identified in Jamaica? If not, why do you think s/he has changed her/his views?

Probes:

- How do your close friends talk about race?

- If they are also racially mixed, do they say anything that might suggest that being mixed is important to them?

- What types of media (TV/movies/music) do your friends prefer?

$\circ$ Do you have any close African American friends? [If no, ask why not. If yes, ask how they talk about race/mixed race. Listen for participant's reactions.] 
13. How would you describe the racial composition of your workplace/school?

Probes:

○ [Note to self: listen for racial categories that reflect U.S. versus Jamaican worldview]

- Would you say that race is an issue, spoken about or not, at your workplace? If so, how?

- How do your coworkers/peers talk about race/racial identification?

- Have you made friends at work or in school? Do they generally belong to one racial group? To which group or groups do they belong?

14. Are you a member of any church or other place of worship/organization/club? How would you describe the racial composition of this church/organization/club?

Probes:

○ [Note to self: listen for racial categories that reflect U.S. versus Jamaican worldview]

- Would you say that race is an issue, spoken about or not, in these organizations? If so, how?

- How do other members talk about race/racial identification?

- Have you made friends in these organizations? Do they generally belong to one racial group? To which group or groups do they belong?

\section{SECTION IV: Racial Identification and the Media}

15. We've talked about your life in Jamaica, and your social and worklife experiences in the U.S. I'm also interested in how you have reacted to what you've seen/heard in the media (TV/Movies/Music). Please tell me what music and movies you like and also about the TV programs/cable stations you watch you watch most frequently.

a. Checklist: TV_ Movies__ Music _

Probes:

TV:

- Do you ever watch programs like Bernie Mac, Everybody Hates Chris, Girlfriends or My Wife and Kids?

- Can you tell me to which characters you feel you most closely relate and why?

- What cable stations do you watch?

- Do you ever watch BET? Why or why not? MUSIC:

- What type(s) of music do you like?

○ What type(s)/what artists do you listen to most frequently?

- Why do you like those types of music/artists?

- Do you listen to rap/Black gospel? Why or why not? 


\section{MOVIES:}

O What types of movies do you generally watch?

- Who are some of your favorite actors/actresses?

○ Why are they your favorites?

Thanks, once more, for your willingness to participate in this study. Your answers have been very helpful. 
Individuals have different types of identities. How would you describe your racial identity in each of the following scenarios?

\section{Section A - Racial Identity on Immigration, Census, or other Forms}

While you lived in Jamaica, how did you identify yourself racially?

[ ] Black

[ ] East Indian

[ ] Chinese

[] White

[ ] Mixed

[ ] Other (Please specify)

How do you currently identify yourself racially? (check all that apply)

[ ] American Indian or Alaskan Native

[] Asian

[ ] Black or African American

[ ] Native Hawaiian or Other Pacific Islander

[] White

[ ] Other (Please specify)

\section{Section B - Racial Identity in Social Situations}

If I am with black Jamaicans in South Florida I would likely identify myself as (choose the term below that best fits even if several terms might fit:

[ ] black

[] white

[] mixed

[ ] Jamaican

[] Other: please specify

If I am with African Americans in South Florida I would likely identify myself as (choose the term below that best fits even if several terms might fit)

[ ] black

[] white

[ ] mixed

[ ] Jamaican

[ ] Other: please specify

If I am with non-Jamaican, non-African American blacks in South Florida I would likely identify myself as (choose the term below that best fits even if several terms might fit) [ ] black 
[ ] white

[] mixed

[ ] Jamaican

[ ] Other: please specify

If I am with Hispanics in South Florida I would likely identify myself as (choose the term below that best fits even if several terms might fit)

[ ] black

[] white

[ ] mixed

[ ] Jamaican

[ ] Other: please specify

If I am with whites in South Florida I would likely identify myself as (choose the term below that best fits even if several terms might fit)

[ ] black

[] white

[] mixed

[ ] Jamaican

[ ] Other: please specify

If I am at a West Indian store in Lauderhill (Broward county) I would likely identify myself as (choose the term below that best fits even if several terms might fit)

[ ] black

[ ] white

[] mixed

[ ] Jamaican

[ ] Other: please specify

If I am at a class at FIU/MDC/FAU/BCC I would likely identify myself as (choose the term below that best fits even if several terms might fit)

[ ] black

[] white

[] mixed

[ ] Jamaican

[ ] Other: please specify

If I am at an African American rap concert I would likely identify myself as (choose the term below that best fits even if several terms might fit)

[ ] black

[] white

[] mixed

[ ] Jamaican

[ ] Other: please specify 
If I am at a predominantly "white" church/social or community event I would likely identify myself as (choose the term below that best fits even if several terms might fit)

[ ] black

[ ] white

[] mixed

[ ] Jamaican

[ ] Other: please specify

Name:

Current residence (city and county)

Age:

Sex:

Marital status:

Race of spouse (if applicable):

Highest level of education completed:

[] High school

[ ] Some college

[ ] Associate degree

[ ] Bachelors degree

[] Masters degree

[] Doctorate

[ ] Other (please specify)

Please indicate your gender

[ ] Male

[ ] Female 


\section{APPENDIX 4}

Jamaican Population by Race $1960-2001$

\begin{tabular}{|c|c|c|}
\hline$\frac{1960}{\text { Category }}$ & $\begin{array}{l}\text { Total } \\
\text { Populat } \\
\text { ion }\end{array}$ & $\begin{array}{l}\% \text { of } \\
\text { Total }\end{array}$ \\
\hline Total & $\begin{array}{r}1,609,8 \\
14 \\
\end{array}$ & 100 \\
\hline African & $\begin{array}{r}1,236,7 \\
06\end{array}$ & 76.82 \\
\hline $\begin{array}{l}\text { Afro- } \\
\text { European }\end{array}$ & 235,494 & 14.63 \\
\hline East Indian & 27,912 & 1.73 \\
\hline $\begin{array}{l}\text { Afro-East } \\
\text { Indian }\end{array}$ & 26,354 & 1.64 \\
\hline Chinese & 10,267 & 0.64 \\
\hline European & 12,428 & 0.77 \\
\hline Afro-Chinese & 9,672 & 0.6 \\
\hline Syrian & 1,354 & 0.08 \\
\hline Other & 49,627 & 3.09 \\
\hline
\end{tabular}

\begin{tabular}{|l|r|r|}
\hline \multicolumn{1}{|c|}{ Category } & $\begin{array}{c}\text { Total } \\
\text { Population }\end{array}$ & $\begin{array}{c}\text { \% of } \\
\text { Total }\end{array}$ \\
\hline Total & $1,797,399$ & 100 \\
\hline Negro/Black & $1,634,686$ & 90.95 \\
\hline East Indian & 30,736 & 1.71 \\
\hline Chinese & 11,781 & 0.66 \\
\hline Amerindian & 304 & 0.02 \\
\hline Portuguese & 85 & 0.01 \\
\hline $\begin{array}{l}\text { Syrian } \\
\text { /Lebanese }\end{array}$ & 1,007 & 0.06 \\
\hline White & 11,841 & 0.66 \\
\hline Mixed & 103,715 & 5.77 \\
\hline Other & 1,381 & 0.08 \\
\hline Not Reported & 1,863 & 0.1 \\
\hline Not Reported & 1,863 & 0.1 \\
\hline
\end{tabular}

\begin{tabular}{|l|r|r|}
\hline Category & $\begin{array}{c}\text { Total } \\
\text { Population }\end{array}$ & $\begin{array}{c}\text { \% of } \\
\text { Total }\end{array}$ \\
\hline Total & $2,595,962$ & 100 \\
\hline Black & $2,378,104$ & 91.61 \\
\hline $\begin{array}{l}\text { East } \\
\text { Indian }\end{array}$ & 23,277 & 0.89 \\
\hline Chinese & 5,153 & 0.2 \\
\hline $\begin{array}{l}\text { White } \\
\text { Mixed }\end{array}$ & 161,234 & 0.18 \\
\hline Other & 2,117 & 0.08 \\
\hline $\begin{array}{l}\text { Not } \\
\text { Reported }\end{array}$ & 21,411 & 0.82 \\
\hline
\end{tabular}

Source: Population Census 2001 Jamaica,

Volume 7; Statistical Institute of Jamaica 2004. 


\section{VITA}

\section{SHARON E. PLACIDE}

2010 - Present

$2008-2009$

$2004-2008$

$1999-2008$

$2004-2006$

$2003-2004$

$1997-2003$

$1993-1997$

April 1995

$1987-1990$

June 1987
Research Assistant, Florida International University Project: "Taking Stock and Moving Forward"

Graduate Assistant, F.I.U. African and African Diaspora Studies

Assistant Dean, The Honors College

Florida International University

Coordinator/Assistant Director

The Honors College Study Abroad in Spain

Instructor - Florida International University

Honors Seminar III - Inhabiting other Lives Pt 1

Honors Seminar IV - Inhabiting other Lives Pt 2

Director of Student Services, The Honors College

Florida International University

Coordinator of Student Services, The Honors College Florida International University

Senior Registration Officer, Office of the Registrar Florida International University

M.A. in Hispanic Studies

Florida International University

Administrative Assistant to Field Staff

Students' Christian Fellowship

Kingston, Jamaica

B.A. in Spanish and History (Honors)

University of the West Indies, Kingston, Jamaica

\section{PRESENTATIONS}

- "Intersections of Race and Gender Among Mixed-Race Jamaican Immigrants," Women's Studies Conference, Florida International University, March 2008. 
- "Encountering the One-Drop Rule: Racial Identity Negotiation Among Racially Mixed Jamaicans in South Florida," Race, Ethnicity and Place IV Conference, University of Miami/James L. Knight Center, November 2008.

- “How Do We Know Ourselves and Others?" Invited Guest lecture, F.I.U. Honors course, November 2007.

- “A Cosmopolitan Experience: Honors Study Abroad in Spain," Miami-Dade Honors Colloquium, Miami-Dade College, Miami, FL, October 2005.

- "Ideas Exchange: Honors Study Abroad," National Collegiate Honors Council Conference, New Orleans, LA, November 2004.

- "Honors Students in Europe," Florida Collegiate Honors Council Conference, Tampa, FL, February 2002.

\section{AWARDS AND HONORS}

- Delores A. Auzenne Fellowship 1991-1992

- Golden Key Honors Society

- Tau Sigma Honor Society

- National Society of Collegiate Scholars

- CUPA Friend Recognition Award 